\title{
Sit at My Right Hand: The Chronicler's Portrait of the Tribe of Benjamin in the Social Context of Yehud
}

\author{
by \\ Benjamin D. Giffone \\ Dissertation presented for the degree of Doctor of Philosophy at the \\ University of Stellenbosch
}

Promoter: Prof. Louis C. Jonker

Faculty of Theology

Department of Old and New Testament

\$ SUTOR014 


\section{Declaration}

By submitting this thesis/dissertation electronically, I declare that the entirety of the work contained therein is my own, original work, that I am the sole author thereof (save to the extent explicitly otherwise stated), that reproduction and publication thereof by Stellenbosch University will not infringe any third party rights and that I have not previously in its entirety or in part submitted it for obtaining any qualification.

March 2014

Copyright (C) 2014 University of Stellenbosch

All rights reserved 


\section{Abstract}

The book of Chronicles is a form of consensus-building literature. The Chronicler's portrayal of Benjamin in relation to Judah reflects an inclusive vision of "all Israel" that walks a fine line: simultaneously valuing Benjamin as an equal partner with Judah (as his "right hand"), yet still protecting the primacy of David as YHWH's chosen ruler, the Levites as the priestly tribe, and Jerusalem as the proper cultic center.

Chronicles' portrait of Benjamin differs from that of the Deuteronomistic History, which portrays Benjamin's relation to Judah as varied and complex. The Chronicler attempts to smooth over these difficulties by highlighting the historically close relationship between the two tribes. In this regard his goals and strategy differ from that of the Deuteronomist, who presents both the high and low points of Judah-Benjamin relations.

The Chronicler's reconstrual of the Judah-Benjamin relationship reflects the socio-political situation of late Persian Yehud, in which the relatively poor Jerusalem cult struggled to gain material support from landed nobility in the region. Material evidence indicates that the historically Benjaminite regions prospered during the Neo-Babylonian and early Persian periods. The Jerusalem cult competed with historically Benjaminite and Josephite cultic locations for the support of wealthier Benjaminite landowners. The Chronicler rewrote Israel's narrative partly in order to garner Benjaminite support for the Jerusalem cult.

This study attempts to synthesize both literary and historical observations: demonstrating a literary phenomenon - the divergent portraits of Benjamin in the Deuteronomistic History and Chronicles - and situating that phenomenon within the historical context of Persian Yehud. The study contributes to the understanding of Yehud during this period, elaborates an important motif in these two sections of the Hebrew Bible, and furthers the investigation of the so-called "Benjaminite substratum" in the Hebrew Bible. 


\section{Opsomming}

Die boek Kronieke is ' $\mathrm{n}$ vorm van konsensus-vormende literatuur. Kronieke se voorstelling van Benjamin in verhouding tot Juda weerspieël 'n inklusiewe visie van "die hele Israel" wat "n fyn lyn bewandel: Benjamin word tegelyk as 'n gelyke vennoot van Juda (as sy "regterhand") gewaardeer, terwyl die prioriteit van Dawid as JHWH se uitverkore heerser, van die Leviete as priesterlike stam, en van Jerusalem as eintlike kultiese sentrum beskerm word.

Kronieke se beeld van Benjamin verskil van dié van die Deuteronomistiese Geskiedenis, wat Benjamin se verhouding tot Juda as geskakeerd en kompleks uitbeeld. Die Kronis probeer hierdie oneffenhede gelykstryk deur die histories eng verhouding tussen die twee stamme te beklemtoon. Hierin verskil sy doel en strategie van dié van die Deuteronomis, wat beide die hoogtepunte en laagtepunte van die Juda-Benjamin verhouding aanbied.

Die Kronis se her-uitbeelding van die Juda-Benjamin verhouding weerspieël die sosiopolitieke situasie van die laat Persiese Jehud, waarin die relatiewe karige Jerusalem kultus gesukkel het om materiële steun te kry van die landbesitters in die streek. Materiële bewyse dui daarop dat die streke wat histories met Benjamin geassosieer is, ekonomies opgebloei het gedurende die NeoBabiloniese en vroeë Persiese periodes. Die Jerusalem kultus het meegeding met die kultiese plekke wat histories met Benjamin en Josef geassosieer is om die steun van die ryker Benjaminitiese landbesitters te verkry. Die Kronis het Israel se verhaal herskryf, onder andere om Benjaminitiese steun vir die Jerusalem kultus te kry.

Hierdie studie probeer om beide literêre en historiese waarnemings te integreer: die literêre fenomeen word verduidelik—naamlik die uiteenlopende uitbeeldings van Benjamin in die Deuteronomistiese Geskiedenis en Kronieke-terwyl die fenomeen in die historiese konteks van Persiese periode Jehud geplaas word. Die studie dra by tot "n beter verstaan van Jehud gedurende hierdie periode, brei uit oor ' $n$ belangrike motief in hierdie twee dele van die Hebreeuse Bybel, en dra by tot navorsing oor die sogenaamde "Benjamin substratum" in die Hebreeuse Bybel. 


\section{Acknowledgements}

I am one of those unusual readers who enjoys reviewing the "acknowledgements" section of (especially) the most academic of books, because the acknowledgments provide a small window into the author's context. As I dedicate this study and reflect upon all those who have aided and supported me through it, I worry that I might inadvertently minimize the contributions of some by the mention of others-that is certainly not my intention.

I am grateful for teachers, colleagues and friends at Cairn University and Westminister Theological Seminary who introduced me to the ancient world of the Bible: Doug Green, Mike Kelly, John Oliff, Fred Putnam, Gary Schnittjer, Brian Toews, and Karyn Traphagen.

My brothers and sisters at Lansdale Presbyterian Church, where my wife and I have worshiped and ministered for several years, have demonstrated patience and encouragement toward me throughout this period of study. Special thanks are due to Scott Wilson, who challenged me and prodded me along when I became tired or discouraged.

I could never have completed this project largely in absentia from Stellenbosch without access to the libraries and resources of Westminster Theological Seminary and Princeton Theological Seminary. My colleagues and supervisors at ICON Clinical Research also encouraged me as I spent many hours reading and writing at my desk after normal business hours. I am especially grateful to Geoff Desiato and Elvis Longin for their support.

When I began graduates studies, I read several "how-to" books on completing a thesis/dissertation. These books filled my head with horror stories of candidates whose dissertations languished for years under the neglect or heavy-handedness of poor doctoral advisors or committees. Professor Louis Jonker has been for me the exact opposite of all these worst fears. His thoughtful comments, constructive criticism, and timely encouragement have enabled the completion of this dissertation. I am grateful to him for taking a chance on an unknown American student, and for allowing me to build upon his careful scholarship in Chronicles and the Persian period. I am also grateful to my examiners, Professors Mark Boda, Hendrik Bosman and Gerrie Snyman, for their thoughtful comments and corrections. The shortcomings that remain in this study are entirely my responsibility.

I am grateful to my parents, Ralph Giffone and Susan Soesbe, for instilling in me a love of learning from a very early age, and for being my primary teachers for the first eighteen years of life. My sister, Rebekah Devine, is my constant dialogue partner in all things pertaining to biblical studies. My younger siblings, Deborah and Michael, keep me on my toes with interesting questions about the Hebrew Bible. 
The marathon that is a doctoral dissertation takes its toll not only on the student but on the student's family. My wife, Corrie, has sacrificed more than anyone else to make this project a success. Corrie has given willingly of her time and energy to manage a household as a working mother of two - to say nothing of the opportunity cost: thousands of hours of her husband's attention, support, and earnings. Not only does she give freely, she takes interest in my work and

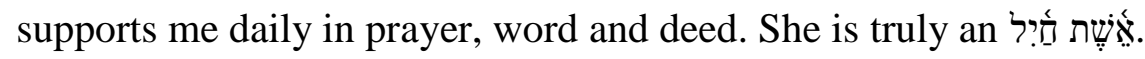

My wife's parents, Rev. Joseph and Claudia Hesh, have tirelessly supported me in my graduate work, teaching, and writing over the last seven years in ways that are too numerous to list. Their love, sacrifice and encouragement have been freely given during times of incredible difficulty for them, including three life-threatening illnesses. Even now, as Joe battles brain cancer, their thoughts and efforts are constantly devoted to others, especially to me, my wife, and our two children. This dissertation is dedicated to Joe and Claudia: may this study bring glory and honor to the God whom they love and serve with all their hearts. 


\section{Table of Contents}

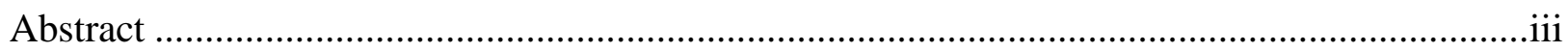

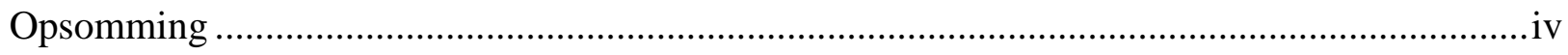

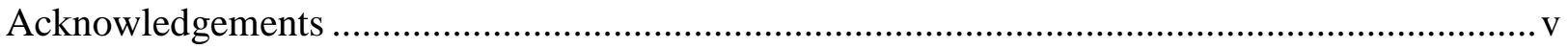

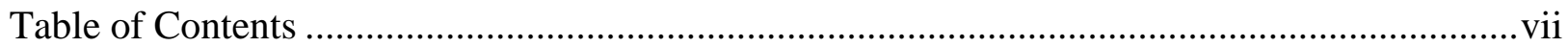

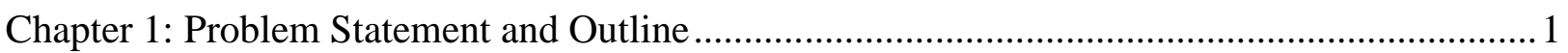

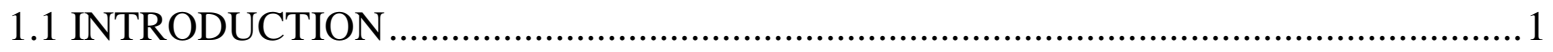

1.1.1 Benjamin in the Hebrew Bible ............................................................................ 1

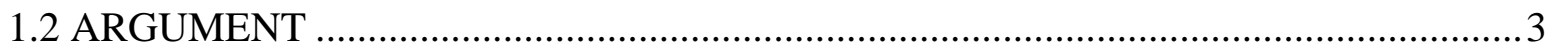

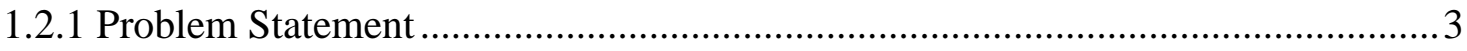

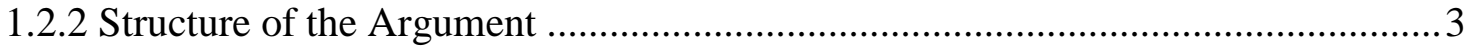

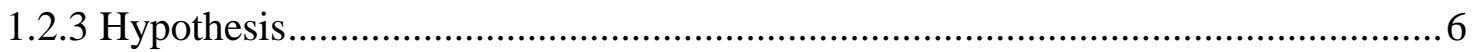

1.3 INTRODUCTORY CONSIDERATIONS: GOALS AND METHODS ......................... 7

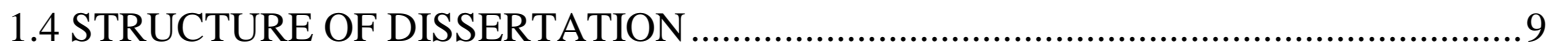

PART I

Chapter 2: Historical-Critical and Social-Scientific Methods ............................................. 10

2.1 HISTORICAL CRITICISM AND LITERARY REPRESENTATION OF HISTORY . 11

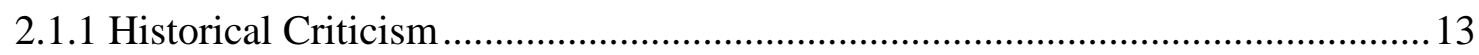

2.1.2 Historical Reconstruction: Limitations ........................................................ 20

2.2 IDENTITIES IN PERSIAN YEHUD: COMMUNITIES AND TEXTS ........................22

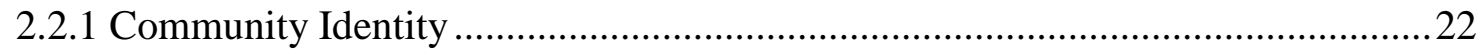

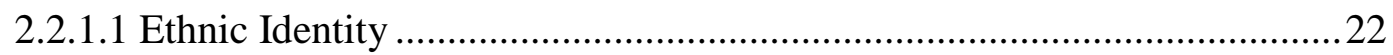

2.2.1.2 Yehudite Identity in the Persian Period................................................24

2.2.1.3 Other Models of Identity ................................................................ 24

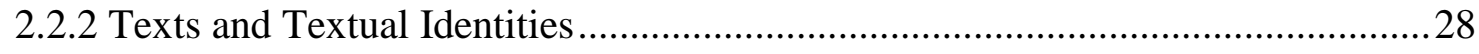

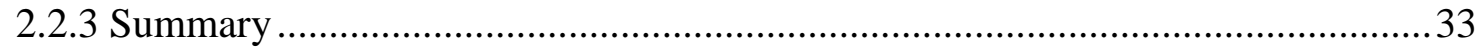

2.3 POLITICAL THEORIES: SELECTORATE THEORY AND HERESTHETICS ..........34 


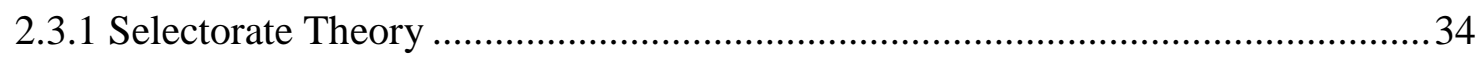

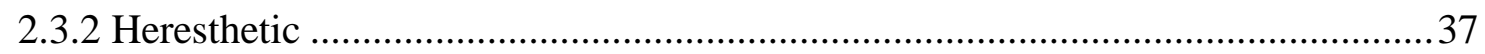

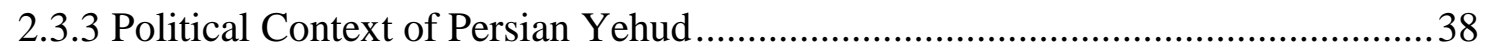

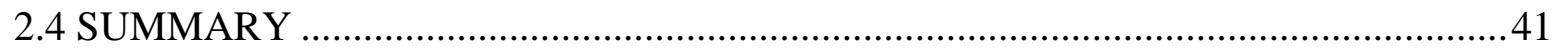

Chapter 3: Chronicles and the Persian Era ...................................................................... 42

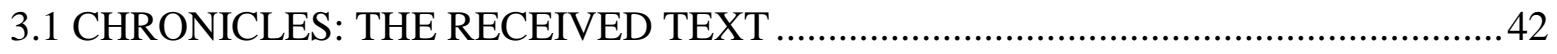

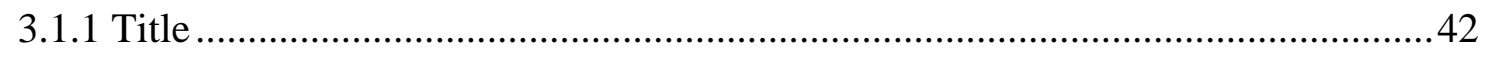

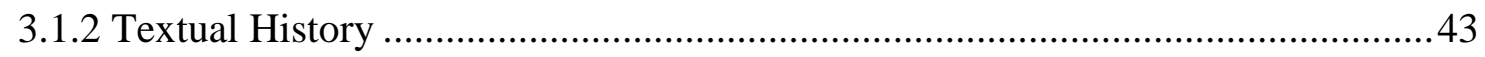

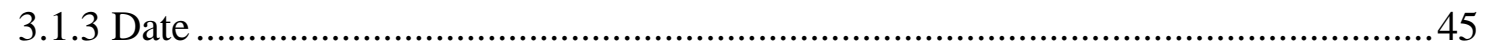

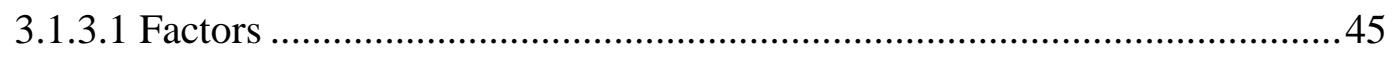

3.1.3.2 How Early and How Late? ....................................................................... 46

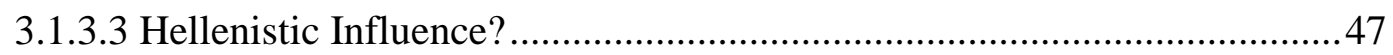

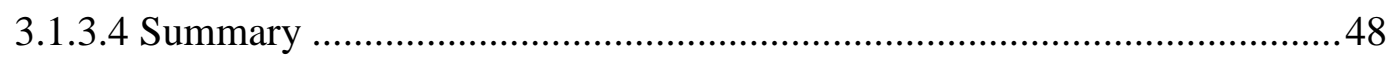

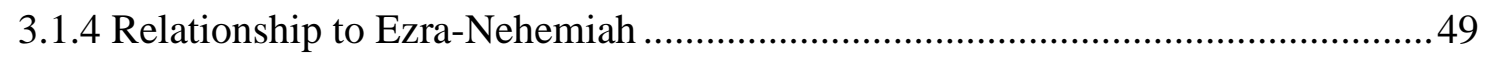

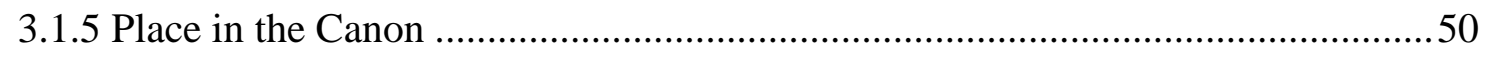

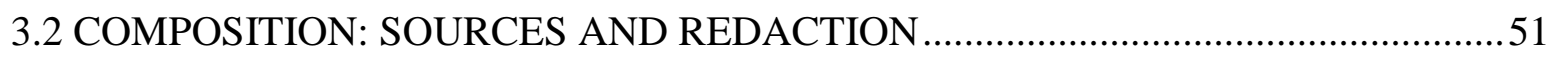

3.2.1 Synoptic Parallels and Apparent Sources ...................................................... 51

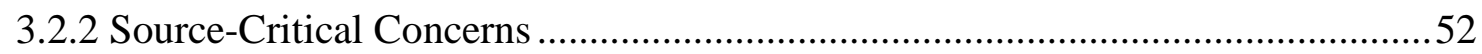

3.2.2.1 Samuel-Kings and Chronicles: A Common Source? ..............................53

3.2.3 Redaction Criticism and Editorial Unity......................................................56

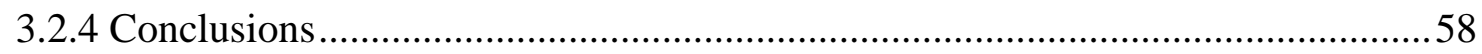

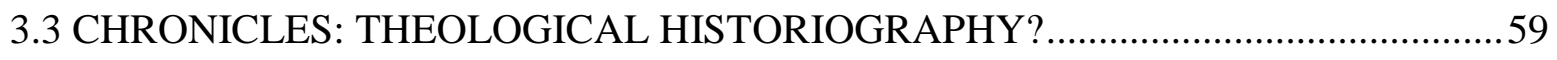

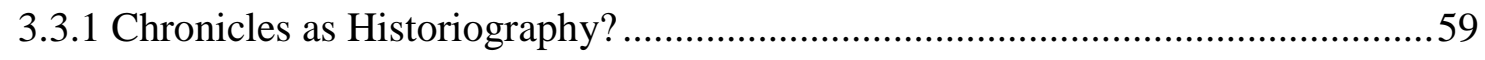

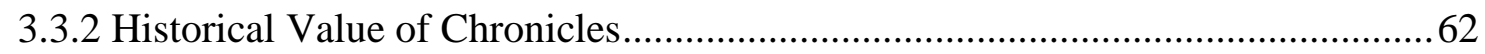

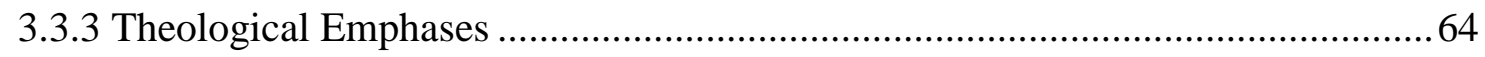

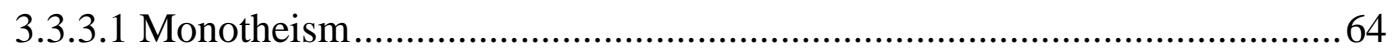

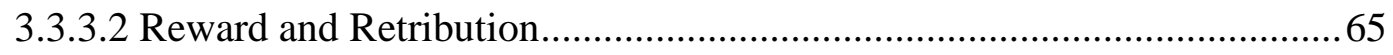

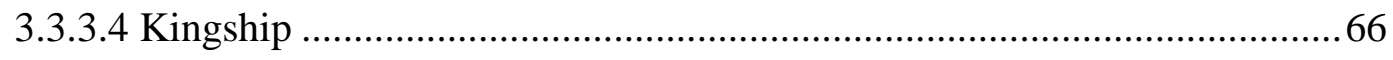

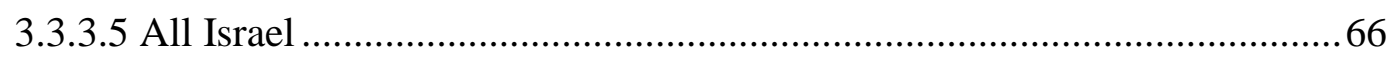

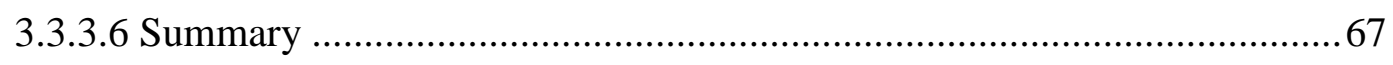

3.4 HISTORICAL SETTING OF CHRONICLES: PERSIAN YEHUD ............................ 67

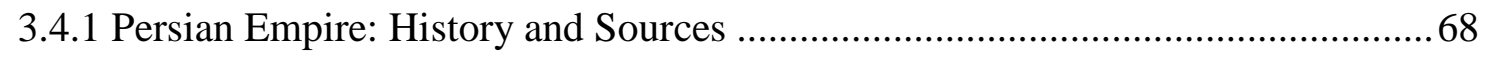




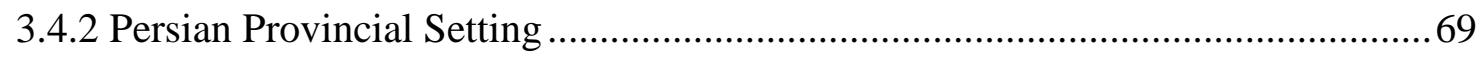

3.4.2.1 Stability of the Persian Hierarchy................................................................ 70

3.4.2.2 Yehud and the Jerusalem Cult in the Persian Hierarchy ............................71

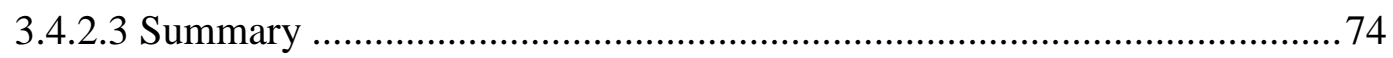

3.4.3 Influence of Persian Context on the Chronicler's Thought? ................................75

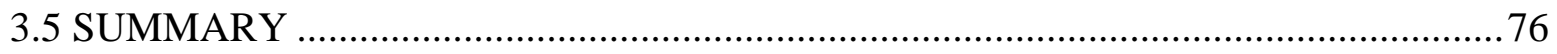

Chapter 4: Benjamin in History and Literature ....................................................................... 78

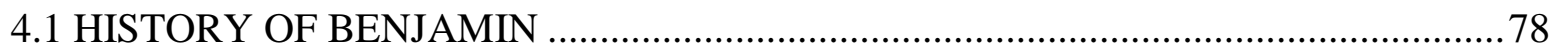

4.1.1 Origins of Israel in the Benjaminite Region ..........................................................79

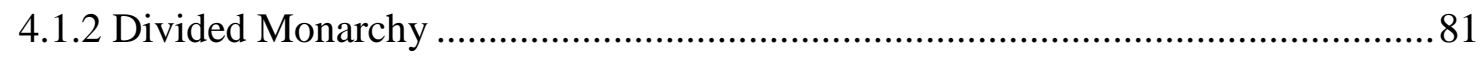

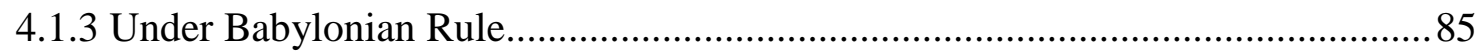

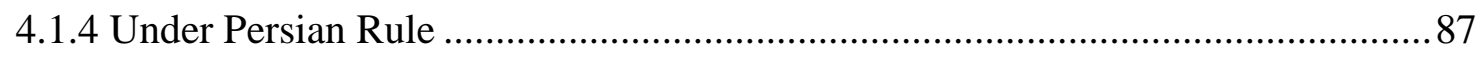

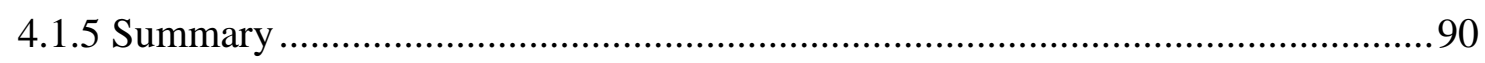

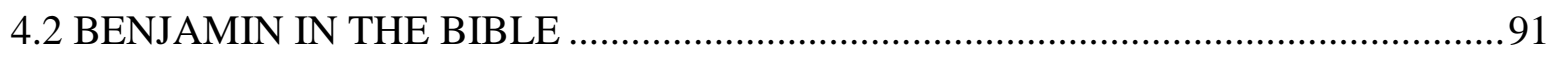

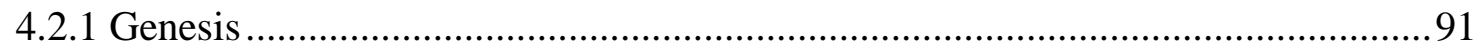

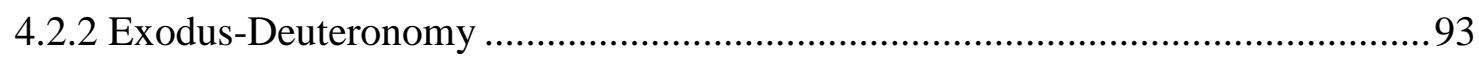

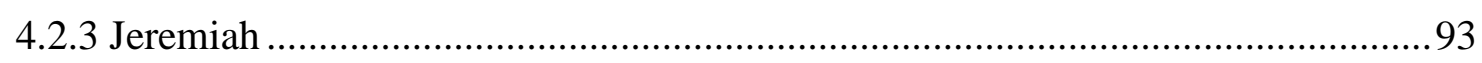

4.2.4 Latter Prophets and Writings ............................................................................99

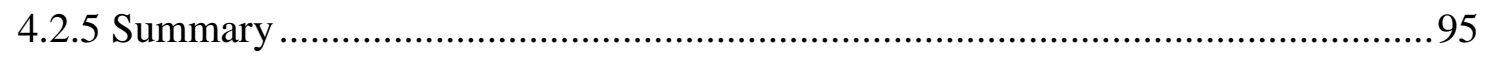

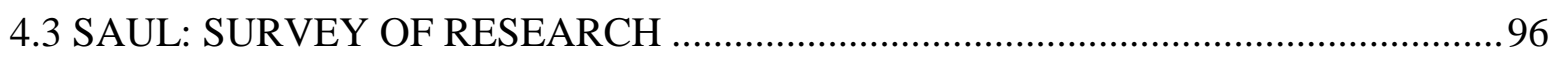

4.3.1 Saul's Characterization: A Mere Foil for David? ………………………...........96

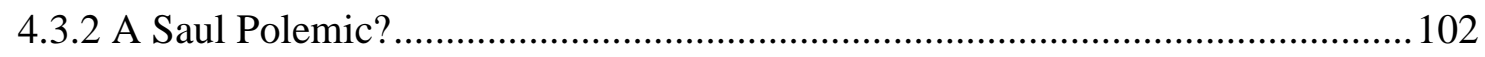

4.3.2.1 Saul in the Persian Imperial Context? ......................................................... 107

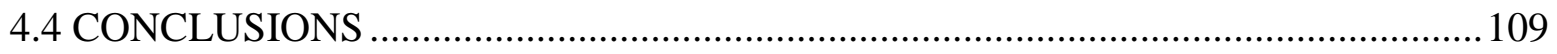

\section{PART II}

Chapter 5: Benjamin in the Deuteronomistic History ..........................................................111

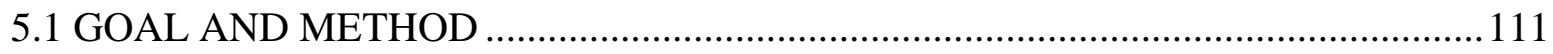

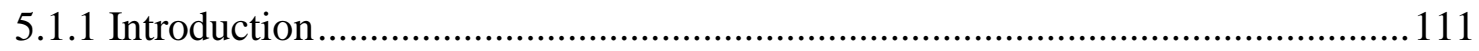

5.1.2 Criteria for Inclusion and Evaluation..............................................................111

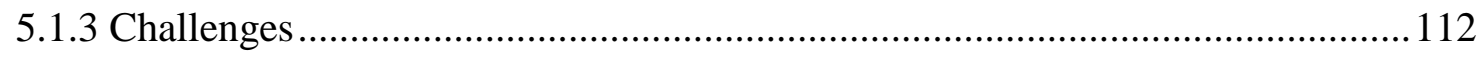




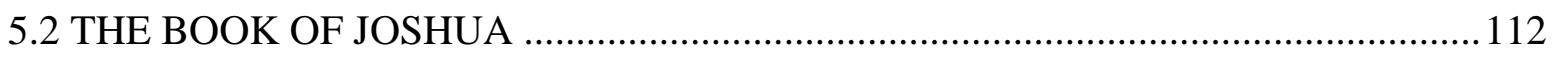

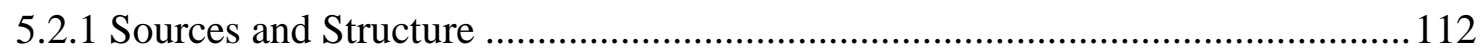

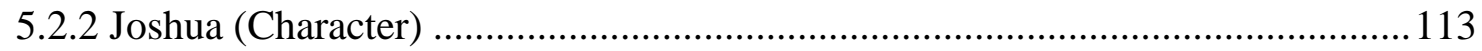

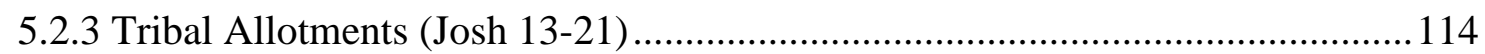

5.2.4 Victory at Jericho (Josh 2-6); Ai and the Achan Affair (Josh 7-8).....................117

5.2.5 Israel and the Gibeonites (Josh 9-10)................................................................ 118

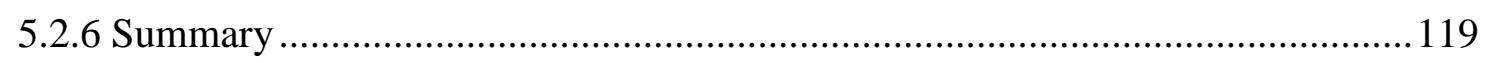

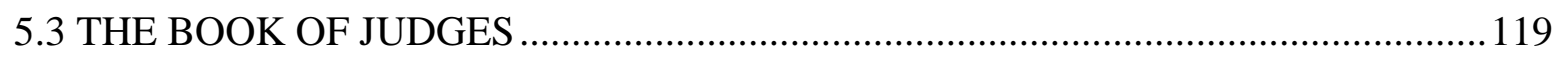

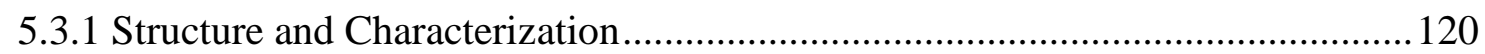

5.3.2 Conquests after Joshua (Jdg 1:1-36) .............................................................. 120

5.3.3 The First Judges: Judahite and Benjaminite (Jdg 3:7-30)...................................122

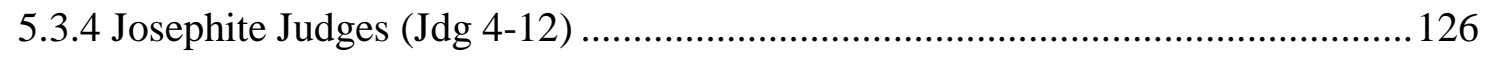

5.3.5 Samson, Micah, and the Danites (Jdg 13-18) ................................................. 127

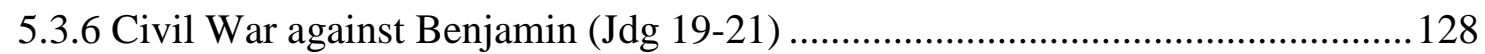

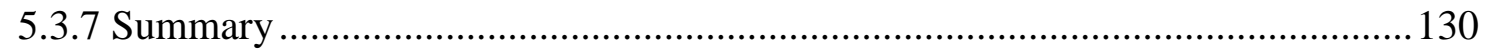

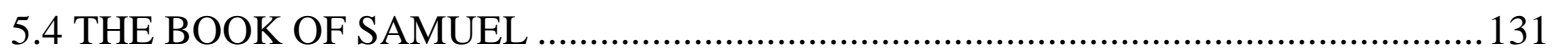

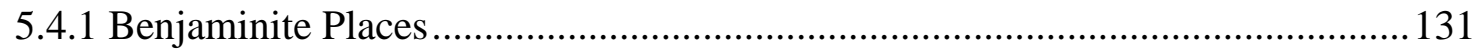

5.4.2 Major Characters in Relation to Benjamin ..................................................... 132

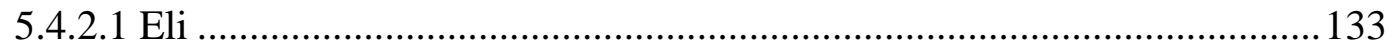

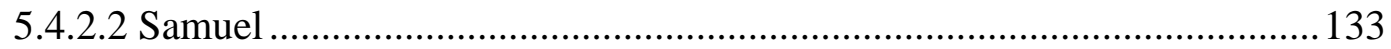

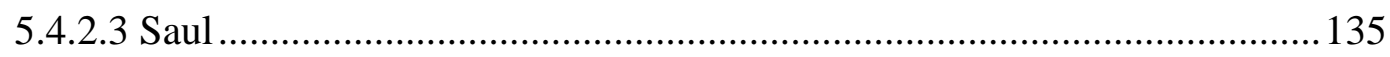

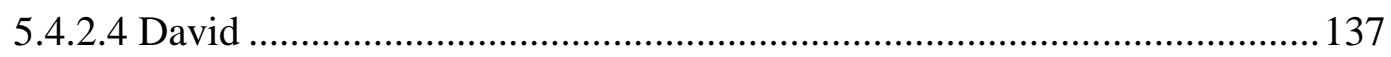

5.4.3 Lesser Benjaminite Characters …………………………………………….....139

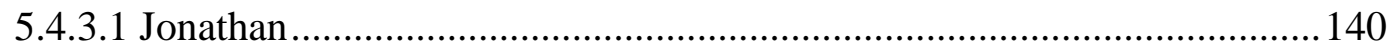

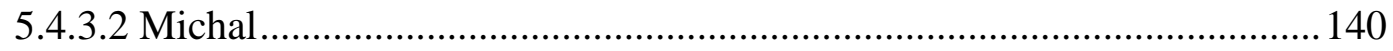

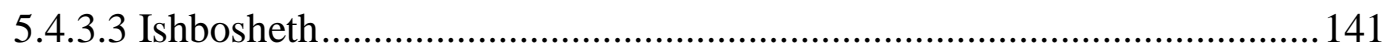

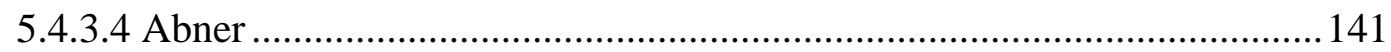

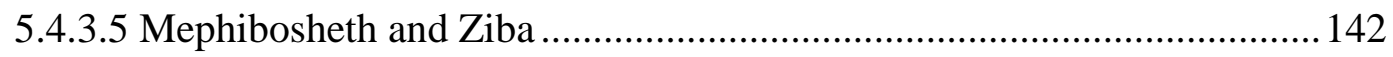

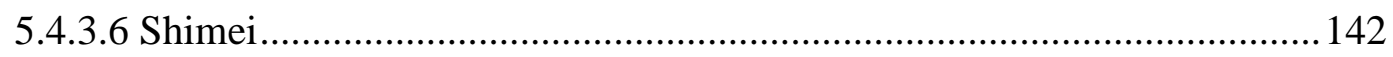

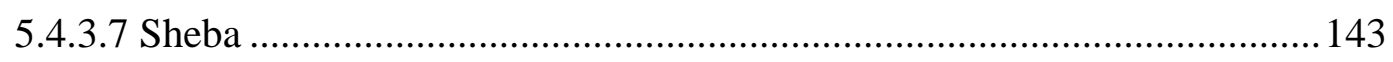

5.4.3.8 Saul's Grandsons ..................................................................................... 143

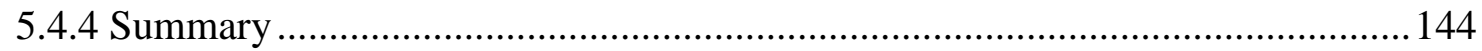

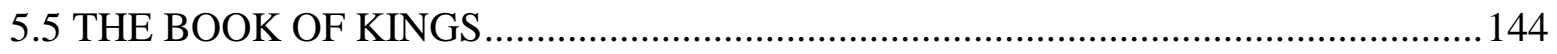




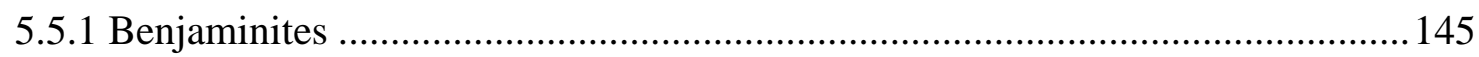

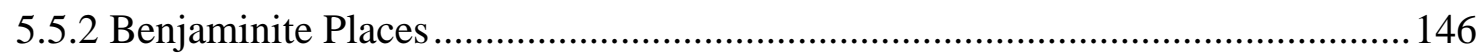

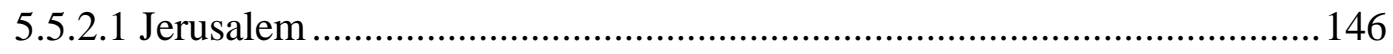

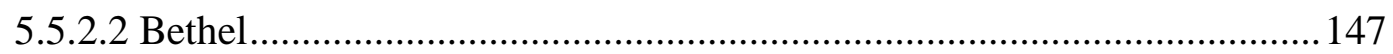

5.5.2.3 Gibeon, Mizpah, and Other Benjaminite Locations ............................... 148

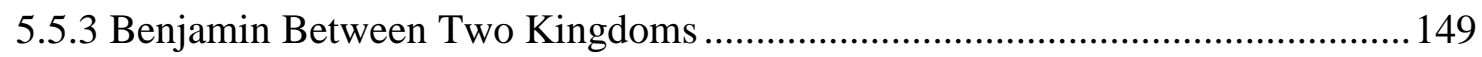

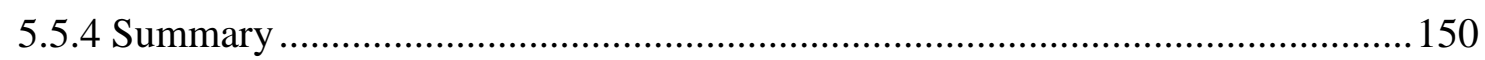

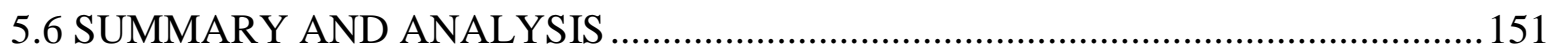

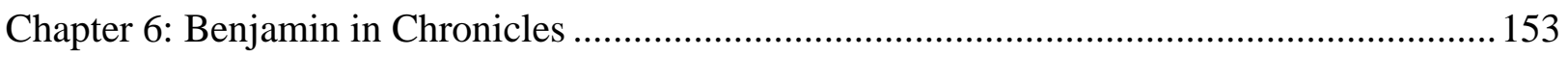

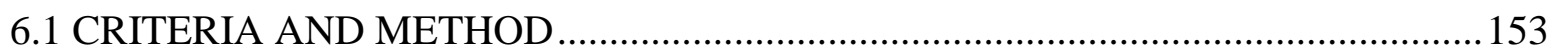

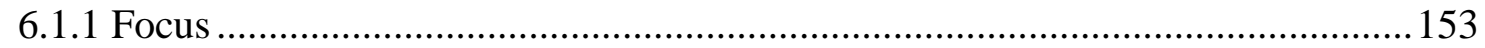

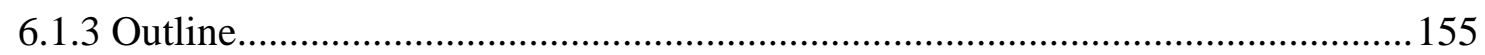

6.2 BENJAMIN, BENJAMINITES, AND BENJAMINITE PLACES …........................... 155

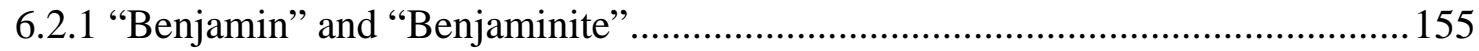

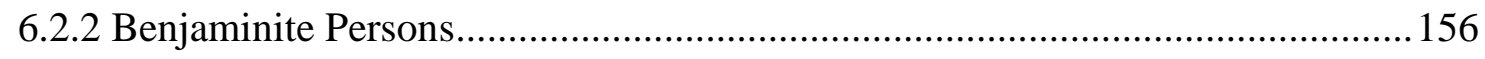

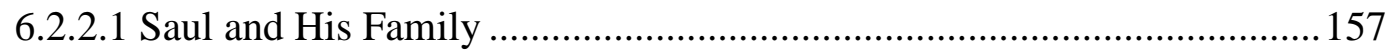

6.2.2.2 Benjaminites Known from the Narratives ........................................... 158

6.2.2.3 Benjaminites Known from the Genealogies? ....................................... 159

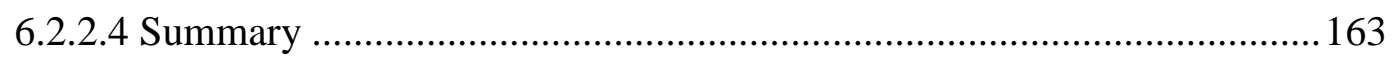

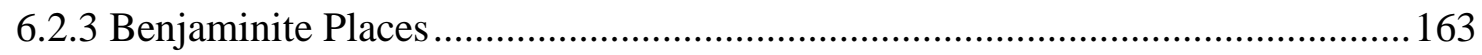

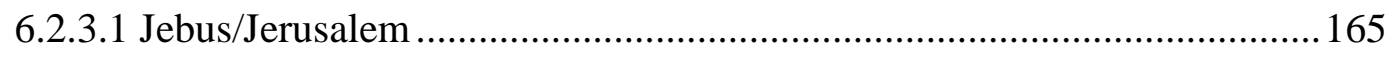

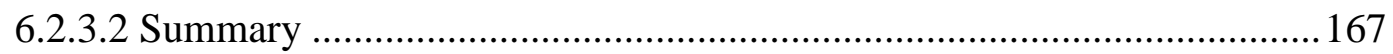

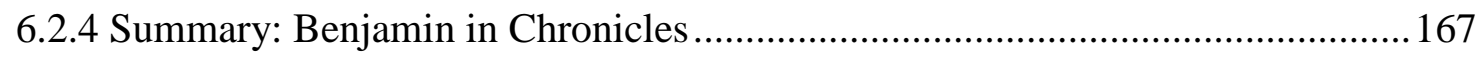

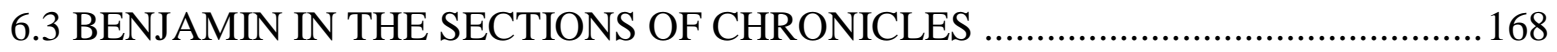

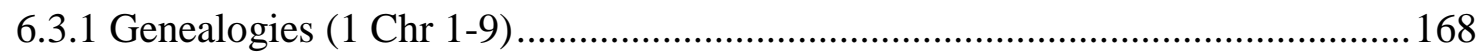

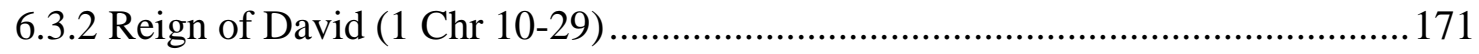

6.3.2.1 Saul's Death and David's Rise (1 Chr 10-12) ...................................... 172

6.3.2.2 Bringing up the Ark (1 Chr 13-16)................................................... 173

6.3.2.3 Establishment and Extension of David's Kingdom (1 Chr 17-20) ......... 174

6.3.2.4 The Census, Temple Preparations, and David's Testament (1 Chr 21-29)

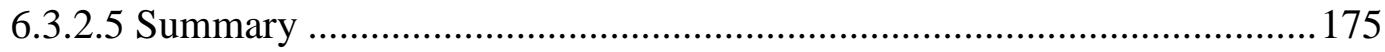




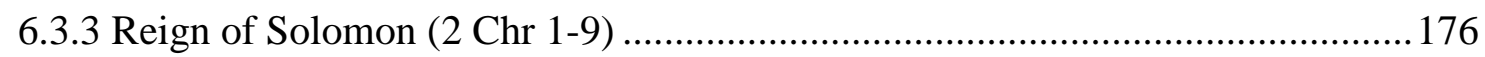

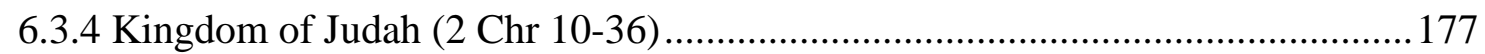

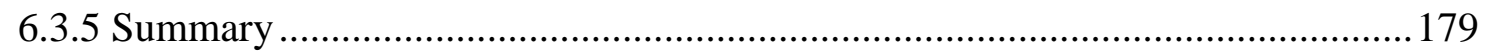

6.4 OMISSIONS FROM THE DEUTERONOMISTIC HISTORY ….............................. 179

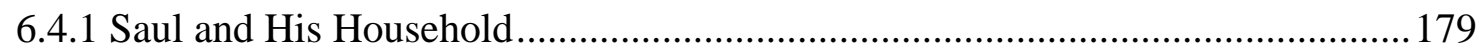

6.4.1.1 Recollections of Saul and His Reign ................................................. 181

6.4.1.2 Jonathan's Love for David ................................................................. 181

6.4.1.3 David's Reign: Saul's Household and Relatives................................... 181

6.4.1.4 Ishbosheth/Eshbaal and Abner ............................................................. 182

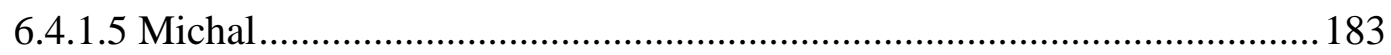

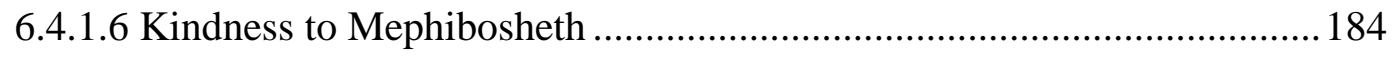

6.4.1.7 Role of Saul's Family in the Absalom Crisis ......................................... 184

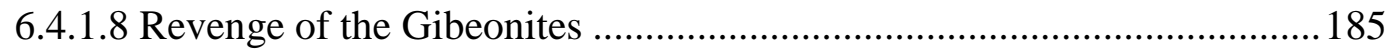

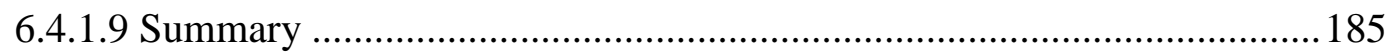

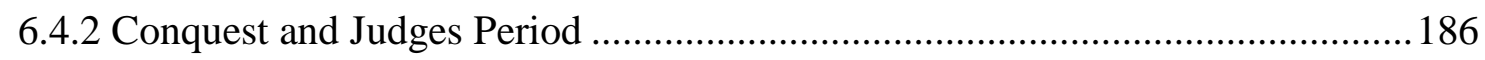

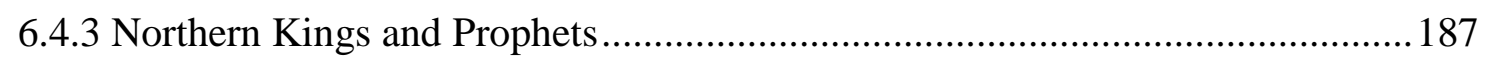

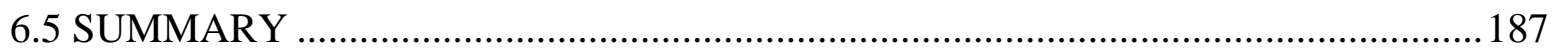

PART III

Chapter 7: The Chronicler's "Benjamin” in Persian Yehud ................................................. 189

7.1 COMPARISON: BENJAMIN IN THE DEUTERONOMISTIC HISTORY AND

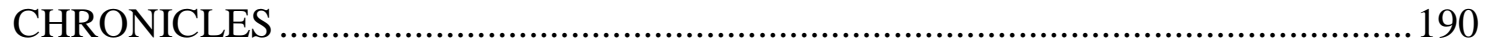

7.1.1 Balanced Portraits of Benjamin: Different Reasons .......................................... 190

7.1.2 Association of Benjamin with Judah ............................................................. 191

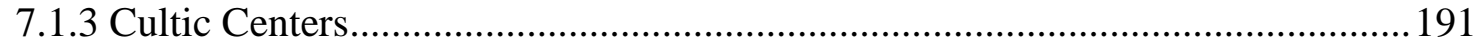

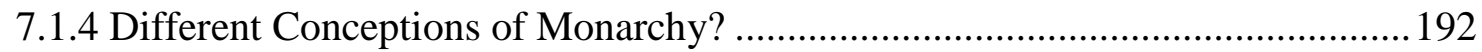

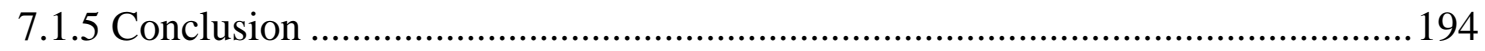

7.2 THE CHRONICLER, THE TRIBE OF BENJAMIN, AND PERSIAN YEHUD........ 194

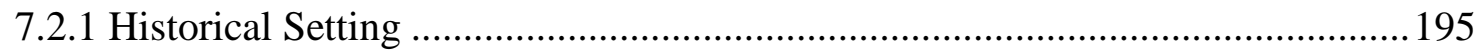

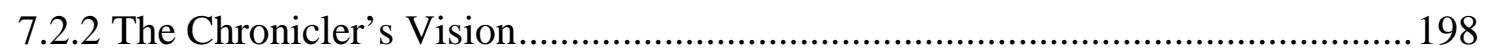

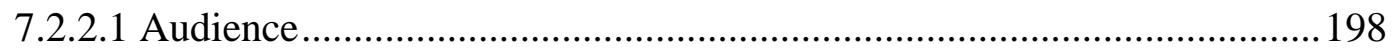

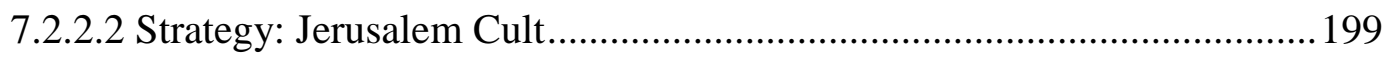


7.2.2.3 Strategy: Davidic Monarchy …........................................................202

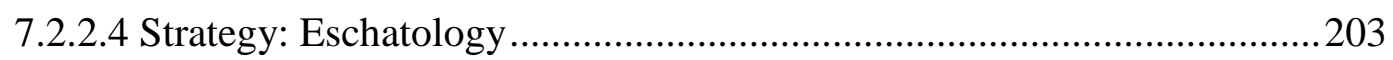

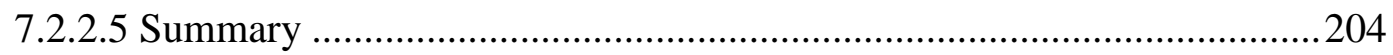

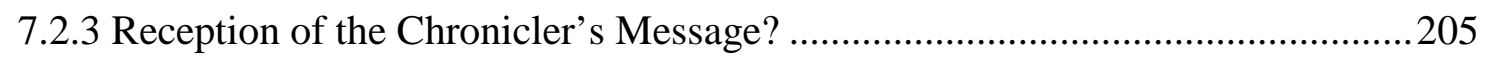

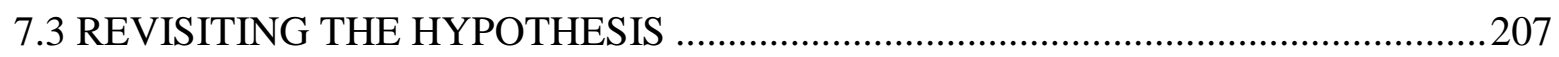

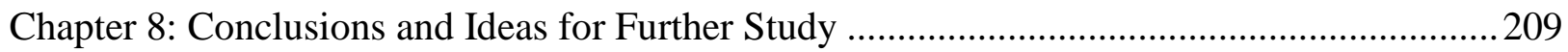

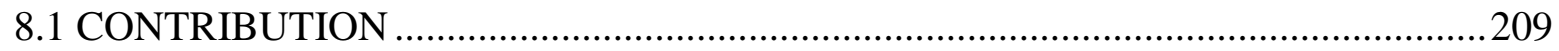

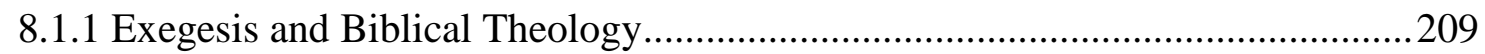

8.1.2 The "Benjaminite Substratum" in the Hebrew Bible..........................................209

8.1.3 The Theologies of the Deuteronomistic History and Chronicles.......................210

8.1.4 Economic and Political Theories/Categories Applied to Historical Contexts ....211

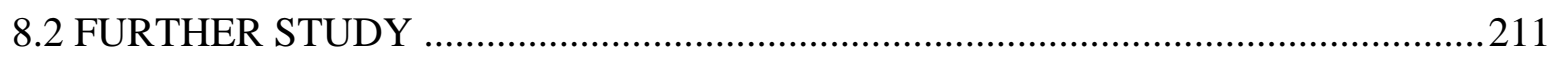

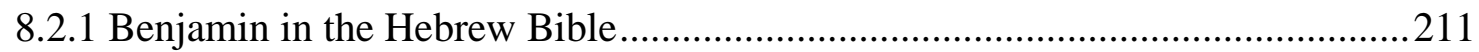

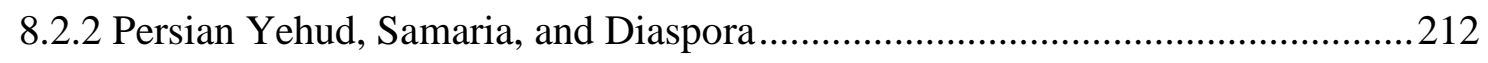

8.2.3 Orality, Textuality, Cult and Education in Yehud ...........................................212

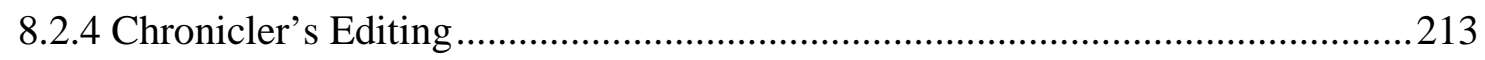

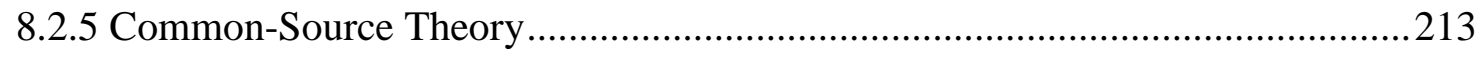

8.2.6 Economics, Politics, and Religion ....................................................................214

Appendix: Benjamin References in Chronicles (Supplement to Chapter 6) ............................216

Table 1: "Benjamin"/“"Benjaminite" in Chronicles...................................................216

Table 2: Saul and his relatives in Chronicles..........................................................2. 218

Table 3: Other (non-Saulide) Benjaminites in the Narrative of Chronicles .................220

Table 4: Benjaminite Places in Chronicles (other than "Jerusalem").........................221

Table 5: Benjamin-related Type Scenes in 2 Chronicles 10-36 ................................223

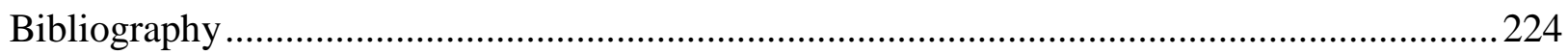




\section{Chapter 1: Problem Statement and Outline 1.1 INTRODUCTION}

Recent scholarship has emphasized the period of Persian rule in Judea (539-331 BCE) as formative for the Hebrew Bible, since many of the canonical texts were composed, edited or compiled during this period. Yet many of the canonical texts reference events that supposedly occurred long before this period. Many studies have explored what can be discerned about the circumstances and beliefs of the people of Persian-era Yehud from these biblical portrayals of Israel's past.

Sectarian conflict in the Persian era is well-established in the scholarly literature. ${ }^{1}$ The main points of conflict appear to have been political, ethnic and religious: who is in charge (under the Persian imperial authority), who exactly is part of our people, and how/where should our people worship? Several studies attempt to show that these conflicts related-inter alia—to a historic rivalry between the tribes of Judah and Benjamin, tribes whose relationship was complex and varied from the very earliest period of Israel's existence.

The book of Chronicles retells Israel's monarchic history by modifying, supplementing and editing material from a previous scriptural work: the Deuteronomistic History (DtrH). Though the DtrH appears to be deeply interested in Judah and David, Chronicles places even greater emphasis on these two themes, as well as the Jerusalem temple and "all Israel." Chronicler's portrayal of Benjamin as a potential partner/rival to Judah is of particular interest, given the survival of these two tribes as "Israel" in the Persian period and their apparently tense relationship.

\subsubsection{Benjamin in the Hebrew Bible}

In his contribution to the Auld Festschrift, Philip Davies comments, "the tribe and territory of Benjamin is an intriguing phenomenon, and remarkably underplayed in biblical scholarship." "2 It seems that the tribe of Benjamin is increasingly becoming a point of entry into discussions of the

${ }^{1}$ Oded Lipschits, The Fall and Rise of Jerusalem: Judah Under Babylonian Rule (Winona Lake, IN: Eisenbrauns, 2005), 358-359; Lester L. Grabbe, A History of the Jews and Judaism in the Second Temple Period, Volume 1: Yehud: A History of the Persian Province of Judah (London: T\&T Clark, 2004), 285-288, 298-302; Joseph Blenkinsopp, "Benjamin Traditions Read in the Early Persian Period," in Judah and the Judeans in the Persian Period (ed. Oded Lipschits and Manfred Oeming; Winona Lake, IN: Eisenbrauns, 2006), 630.

${ }^{2}$ Philip R. Davies, “The Trouble With Benjamin,” in Reflection and Refraction: Studies in Biblical Historiography in Honour of A. Graeme Auld (ed. R. Rezetko et al.; Leiden: Brill, 2007), 93. 
historical origins of Israel and of the Persian period as a formative era for the Hebrew canon and Jewish religion, as well as questions of the nature of Jewish identity (both past and present). ${ }^{3}$

Davies, for example, points out the apparent flexibility in the self-identity of Saul/Paul of Tarsus: the remarkable notion that a proud "Israelite" (Rom 11:1) of the tribe of Benjamin (Rom

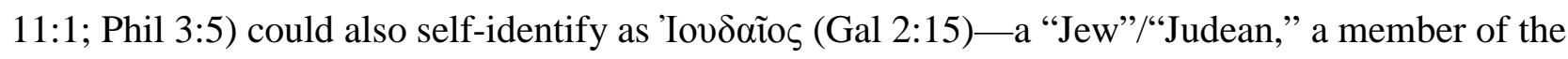
people of יהודה. י. Davies also raises the example of the book of Esther. Esther and Mordecai are Benjaminites descended from Kish (Est 2:5), a designation which "evokes king Saul," and they defeat Haman "the Agagite," a reference to Saul's failure to kill the king of the Amalekites for which he was stripped of his kingship. Yet Mordecai and Esther self-identify as יהודים. Davies summarizes the tension: "We now have two cases of individual Benjaminites, and their families, fiercely loyal to the memory of the first king of Israel and his family. What implications does such a loyalty have for the attitudes of Benjaminites towards Jerusalem—and towards the kings of Judah?"5

Davies' observation is made in service of an argument concerning the process of canon formation-an issue which is beyond the narrower interest of this study. But many scholars have also identified evidence of what Davies calls the "Benjaminite substratum" in the Hebrew Bible. ${ }^{6}$ This evidence consists largely of references to Benjaminite people and places, particularly as those people and places are set in relation to the tribe of Judah. The tribes of Judah, Levi and Benjamin appear to have been the primary constituent tribes of the Jewish people during the Persian period, and these distinctions appear to have had continued relevancy in Jewish communities for centuries afterward. If, in fact, the Persian period was a formative time for much of the Hebrew canon, it would be reasonable to expect that Persian-era concerns-including intertribal relations-would have left their mark on that canon.

${ }^{3}$ Recently, see especially Daniel E. Fleming, The Legacy of Israel in Judah's Bible: History, Politics, and the Reinscribing of Tradition (New York: Cambridge University Press, 2012).

${ }^{4}$ Davies, "Trouble with Benjamin," 94-96.

${ }^{5}$ Davies, "Trouble with Benjamin," 96-97.

${ }^{6}$ Davies, “Trouble with Benjamin,” 111. A few examples include: Blenkinsopp, "Benjamin Traditions,” 629645; Louis C. Jonker, “Of Jebus, Jerusalem and Benjamin: The Chronicler's Sondergut in 1 Chronicles 21 Against the Background of the Late Persian Era in Yehud," in Chronicling the Chronicler: The Book of Chronicles and Early Second Temple Historiography (ed. Tyler F. Williams and Paul S. Evans; Winona Lake, IN: Eisenbrauns, 2013), 81102; Yigal Levin, “Joseph, Judah and the 'Benjamin Conundrum,” ZAW 116 (2004): 223-241; Nadav Na'aman, "Saul, Benjamin and the Emergence of 'Biblical Israel' (Parts 1 \& 2)," ZAW 121 (2009): 211-224, 335-349. These and other studies will be considered in greater detail in a subsequent chapter. 


\subsection{ARGUMENT}

The following section states in brief the question addressed in this study, as well as the basic premises of the argument and the hypothesis.

\subsubsection{Problem Statement}

The present study wants to investigate the following question: How should the different portrayals of the tribe of Benjamin in DtrH and Chronicles be interpreted, and what does this reflect of the relationship between Judah and Benjamin? The study will therefore involve a detailed comparison of the biblical portrayals of Benjamin and Benjaminites-particularly in relation to Judah-within the DtrH and Chronicles. The differences and continuities, particularly in the Chronicler's use of (or omission of) Deuteronomistic material, will be a key to understanding the relationship of these two groups in the Chronicler's time.

\subsubsection{Structure of the Argument}

1) The Persian period was a formative time for the Hebrew canon and for Judaism. ${ }^{7}$ Both the Pentateuch $^{8}$ and the Deuteronomistic History, ${ }^{9}$ which together form the narrative backbone of the Hebrew Bible, apparently reached their canonical form during this period. Many of the books of the Latter Prophets and the Writings were composed, compiled or edited during this period. The Babylonian conquest - a theological catastrophe as well as a social and political one — served as a catalyst for theological reflection and development, ${ }^{10}$ which continued into the Persian period.

2) It is therefore reasonable to expect that Persian-era concerns_-including intertribal relations-would have left their mark on that canon. ${ }^{11}$ The exilic and post-exilic Yahwistic

${ }^{7}$ Gary N. Knoppers, 1 Chronicles 1-9 (Anchor Bible Commentary; New York: Doubleday, 2004), 101; Armin Siedlecki, “'Persian Period Studies Have Come of Age,"” in Historiography and Identity (Re)formulation in Second Temple Historiographical Literature (ed. Louis C. Jonker; New York: T\&T Clark, 2010), 123.

${ }^{8}$ David A. Glatt-Gilad, "Chronicles as Consensus Literature,” in What Was Authoritative for Chronicles? (ed. Ehud Ben Zvi and Diana Edelman; Winona Lake, IN: Eisenbrauns, 2011), 69. See also Jean-Louis Ska, Introduction to Reading the Pentateuch (trans. Sr. Pascale Dominique; Winona Lake, IN: Eisenbrauns, 2006); Gary N. Knoppers and Bernard Levinson, eds., The Pentateuch as Torah: New Models for Understanding Its Promulgation and Acceptance (Winona Lake, IN: Eisenbrauns, 2007).

${ }^{9}$ Thomas C. Römer, The So-Called Deuteronomistic History: A Sociological, Historical and Literary Introduction (London: T\&T Clark, 2005), $165 \mathrm{ff}$.

${ }^{10}$ Ralph W. Klein, Israel in Exile: A Theological Interpretation (Philadelphia: Fortress Press, 1979), 3-8.

${ }^{11}$ Blenkinsopp writes: "There is broad agreement that the two centuries of Persian rule were decisive for the compilation and redaction of the core material that came to form the biblical canon, and it would be surprising if the political conflicts of that period had left no mark on the texts themselves; quite apart from the possibility that some of 
community chose to preserve and reflect upon those images of its past that were most relevant to its present situation. The Chronicler was no exception in this regard; in fact, the Chronicler's work is particularly valuable to our understanding of this sort of reflection because much of his adapted/edited/modified source material is preserved in earlier canonical texts. ${ }^{12}$ Chronicles is therefore of significant value to historical reconstructions of the socio-political and religious situation of Persian-era Yehud.

3) The tribes of Judah, Levi and Benjamin were the primary constituent tribes of the people of Yehud during the Persian period, and these distinctions appear to have had continued relevancy in Jewish communities for centuries afterward. After Benjamin came to be associated with the Southern Kingdom and the Northern Kingdom was captured by Assyria, the people of the Judahite and Benjaminite tribal regions (including the Levites associated with the Jerusalem cult) constituted the kingdom of Judah that was subdued by The Babylonians between 598 and 582 BCE. These three tribes are prominent in the Chronicler's genealogies (1 Chr 2:3-4:23; 6:1-81; 8:1-9:1), and the returnees from Babylon were primarily (or perhaps exclusively) members of these tribes (1 Chr 9:2$44){ }^{13}$

4) Based on textual and archaeological evidence, sectarian conflict existed in the Persian period, including tensions between the largely Benjaminite she' rit $^{14}$ community and the Jerusalemite (and Levite) golah community. ${ }^{15}$ This statement simplifies what was undoubtedly a more complex social situation; further exploration will be necessary to describe the tribal

these texts may have been composed at that time" ("Benjamin Traditions Read in the Early Persian Period," 630). Erhard S. Gerstenberger, Israel in the Persian Period: The Fifth and Fourth Centuries B.C.E. (trans. Siegfried S. Schatzmann; Atlanta: SBL, 2011 [2005]), notes: "Practically all the canonical writings (except for Ecclesiastes and Daniel), whether intentionally or unintentionally, express something about the situation of the Judaic communities in the Persian era" (35).

${ }^{12}$ Sara Japhet (I \& II Chronicles: A Commentary; Old Testament Library Series; Louisville: Westminster John Knox Press, 1993) notes, "That the Chronicler had strong historical and theological motives in writing his work is selfevident; why else would he bother to rewrite the history of a period which was already documented?" (43)

${ }^{13}$ Even though the Chronicler mentions that the returning golah community included people of Ephraim and Manasseh as well (1 Chr 9:3), no persons or families of these tribes are listed in the following genealogical lists. Knoppers notes, “This is in keeping with the Chronicler's comprehensive notion of Israelite identity. Nevertheless, the point should not be pressed too far. The succeeding verses, which deal only with Judah, Benjamin, and Levi, neglect Ephraim and Manasseh entirely" (1 Chronicles 1-9, 501). The question of the exact tribal identities of Yehudites and the historical validity of claims to other tribal identities will be addressed in later sections $(\S 6.3 .1, \S 7.2 .2 .1)$.

14 The use of the term שארית ("remnant"/"leftover"), which refers to the communities of Judahites left in the land after 587 BCE (analogous to גולה, "exile"), is purely descriptive, chosen to avoid the theological connotations of the English term "remnant."

${ }^{15}$ Yigal Levin, “Who Was the Chronicler's Audience? A Hint from His Genealogies,” JBL 122 (2003): 239- 
backgrounds of the various groups and the exact nature of their conflicts. But since the deportees were primarily Jerusalemites, while the Benjaminite areas were continuously inhabited (and possibly even flourished) during the sixth century $\mathrm{BCE},{ }^{16}$ the initial conflicts in the early Persian period between the returnees to Yehud and the province's inhabitants may be generally characterized as a Judah-Benjamin rivalry. Given the ongoing significance of tribal identity, it is reasonable to explore the extent, duration and manifestation of such a rivalry during the whole Persian period.

5) Two key elements of the Chronicler's agenda appear to be the support of the Jerusalem cult and the definition of "all Israel." The phrase כל ישראל occurs forty-six times in Chronicles, and both the Chronicler's genealogies and narrative additions exhibit concern for all the tribes of Israel. Chronicles contains lengthy additions to the DtrH which focus on the pedigree and roles of the Levites and priests in relation to the Jerusalem temple.

6) Based on premises 2, 4 and 5: the Chronicler's presentation of Benjamin in relation to the royal tribe of Judah-Benjamin being the only other self-standing tribe ${ }^{18}$ besides Judah and Levi in the Persian period-is an important "test case" of the Chronicler's vision of "all Israel" and the Jerusalem cult. The Chronicler favors Davidic royalty and Levitical cult leadership-Benjamin thus becomes the key foil to these "special" tribes and the main target audience for the Chronicler's "all Israel" message. $^{19}$

7) The Chronicler respectfully but purposefully appropriates and reshapes canonical material for his contemporary audience (and beyond). It would be an understatement to remark that issues surrounding the Chronicler's use of sources have become central to Chronicles scholarship. ${ }^{20}$

${ }^{16}$ Oded Lipschits, “The History of the Benjamin Region under Babylonian Rule,” Tel Aviv 26 (1999): 179.

${ }^{17}$ Japhet, I \& II Chronicles, 45-47; Ralph W. Klein, 1 Chronicles: A Commentary (Hermeneia series; Minneapolis: Fortress Press, 2006), 45-46; Knoppers, 1 Chronicles 1-9, 89.

${ }^{18}$ The Levites had not traditionally had a demarcated tribal region of their own, but had been interspersed among the other tribes (Lev 25:32-33; Num 35:1-8; Josh 14:4; 21:1-42).

${ }^{19}$ Knoppers concludes a comparison of the themes of Chronicles and Ezra-Nehemiah: "One should not lose sight of the fundamental postulates all three books share about matters such as the primacy of Jerusalem, the exclusive status of the Jerusalem Temple, the importance of supporting the priests and Levites, and the critical role that Judah, Levi, and Benjamin have in upholding the legacy of ancient Israel" (1 Chronicles 1-9, 89).

${ }^{20}$ See for example, the following edited works and extensive treatment in commentaries: M. Patrick Graham and Steven L. McKenzie, eds., The Chronicler as Author: Studies in Text and Texture (JSOTSup 263; Sheffield: Sheffield Academic Press, 1999); Ehud Ben Zvi and Diana Edelman, eds., What Was Authoritative for Chronicles? (Winona Lake, IN: Eisenbrauns, 2011); Japhet, I \& II Chronicles, 14-22; Knoppers, 1 Chronicles 1-9, 52-71; Klein, 1 Chronicles, 26-44. This study will make use of Chronicles and Its Synoptic Parallels in Samuel, Kings, and Related Biblical Texts (ed. John C. Endres, William R. Millar, and John Barclay Burns; Collegeville, MN: The Liturgical Press, 1998) as a helpful tool for comparisons between Chronicles and its sources. 
This issue will be explored in greater detail at a later point in this study. At this juncture, it will suffice to point out that the Chronicler assumed that his sources had canonical status and were (to an extent) familiar to his audience, but nevertheless saw the need to re-write the tradition. This remarkable undertaking was undoubtedly motivated by contemporary concerns that the Chronicler viewed as pressing, crucial, and complex.

8) Based on premises 6 and 7: A comprehensive comparison between the presentations of Benjamin and its relations with Judah in Chronicles and in the DtrH (the Chronicler's main source) will offer a significant contribution to the understanding of the Chronicler's context, his ideology of "all Israel," and his view of the centrality of the Jerusalem cult.

Such a study might establish fundamental continuity between Chronicles and the DtrH on these issues. Continuity and similarity would still be as significant an historical finding as discontinuity, given the differences between these works in literary structure, themes, and historical background. ${ }^{21}$ Most likely, there will be significant elements of both continuity and discontinuity between the presentations of Benjamin and intertribal relations in the DtrH and Chronicles.

\subsubsection{Hypothesis}

This study takes the view that Chronicles is a unique form of consensus-building literature. ${ }^{22}$ The study will attempt to demonstrate that the Chronicler's portrayal of Benjamin in relation to Judah reflects an inclusive vision of "all Israel" that walks a fine line: simultaneously valuing Benjamin as an equal partner with Judah (as his "right hand"), yet still protecting the primacy of David as YHWH's chosen ruler, the Levites as the priestly tribe, and Jerusalem as the proper cultic center.

Chronicles' portrait of Benjamin differs from that of the DtrH, which portrays Benjamin's relation to Judah as varied and complex. The Chronicler attempts to smooth over these difficulties by highlighting the historically close relationship between the two tribes. In this regard his goals

${ }^{21}$ Recently, however, the pendulum is swinging back toward an emphasis on the points of agreement between the DtrH and Chronicles; see Ehud Ben Zvi, “Are There Any Bridges Out There? How Wide Was the Conceptual Gap Between the Deuteronomistic History and Chronicles?" in Community Identity in Judean Historiography: Biblical and Comparative Perspectives (ed. Gary N. Knoppers and Kenneth A Ristau; Winona Lake, IN: Eisenbrauns, 2009), 59-86; Gary N. Knoppers, “The Relationship of the Deuteronomistic History to Chronicles: Was the Chronicler a Deuteronomist?" in Congress Volume Helsinki 2010 (Proceedings of the $20^{\text {th }}$ Congress of the International Organization for the Study of the Old Testament, ed. Martti Nissinen; VTSup 148; Leiden: Brill, 2012), 307-341; Louis C. Jonker, "Was the Chronicler More Deuteronomic Than the Deuteronomist? Explorations into the Chronicler's Relationship With Deuteronomic Legal Traditions," SJOT 27 (2013): 191-203.

${ }^{22}$ Glatt-Gilad, "Chronicles as Consensus Literature," 67-75. 
and strategy differ from that of the Deuteronomist, who presents both the high and low points of Judah-Benjamin relations.

\subsection{INTRODUCTORY CONSIDERATIONS: GOALS AND METHODS}

My master's thesis (Stellenbosch, 2012) posited a unifying rhetorical function of the book of Lamentations during the Persian period. ${ }^{23}$ Amid the conflict in the Persian period between the returning golah (primarily Judahite) communities and the surviving existing she'erit (primarily Benjaminite) communities, the book of Lamentations may have been intended to unite the two groups through shared suffering.

In postulating a unifying/consensus-building rhetorical function of Chronicles vis-à-vis these two tribes, the present study will have much in common with the previous one. Historical and literary criticism will be of equal import, subservient to the goal of aiding interpretation of the text itself. For the study of a performance-oriented work of poetry such as Lamentations, literary criticism and rhetorical criticism are quite closely linked. The present study would need further to explore the different functions of a scribal work in elite circles and among an illiterate, oral population. $^{24}$

My own approach to historical criticism could be described quite broadly as critical realism, in line with the approach outlined by Grabbe ${ }^{25}$ and elaborated in my thesis. ${ }^{26}$ Regarding the historical value of the biblical texts, neither blind acceptance nor blatant disregard is appropriate. Rather, careful comparison with extrabiblical sources is necessary in order to discern how exactly the biblical author/editor/redactor is presenting the historical data. A biblical portrait of history is both historiography that may be assessed critically for historical value, and also a historical datum itself — a witness to the thoughts, attitudes and ideals of the author(s).

${ }^{23}$ Benjamin Giffone, "From Time-Bound to Timeless: The Rhetoric of Lamentations and Its Appropriation" (MTh thesis, Stellenbosch University, 2012), <http://hdl.handle.net/10019.1/20205>.

${ }^{24}$ Peter L. Berger and Thomas Luckmann, The Social Construction of Reality: A Treatise in the Sociology of Knowledge (New York: Anchor Books, 1967 [1966]), 15. Relevant studies include: Raymond F. Person, The Deuteronomic History and the Book of Chronicles: Scribal Works in an Oral World (Atlanta: Society of Biblical Literature, 2010); Karel van der Toorn, Scribal Culture and the Making of the Hebrew Bible (Cambridge: Harvard University Press, 2009); David M. Carr, Writing on the Tablet of the Heart: Origins of Scripture and Literature (New York: Oxford University Press, 2005); Susan Niditch, Oral World and Written Word: Ancient Israelite Literature (Louisville: Westminster John Knox Press, 1996).

${ }^{25}$ Grabbe, History of the Jews and Judaism Vol. 1, 2-17.

${ }^{26}$ Giffone, "From Time-Bound to Timeless," 6-15. 
At the outset, several limitations of the line of study proposed must be considered. First of all, archaeological discoveries can only reveal so much about particular peoples in specific periods of time. It seems reasonably well-established in current scholarship that Jerusalem suffered greatly at the hands of the Babylonians but that the Benjaminite areas did not experience significant troubles between $598 \mathrm{BCE}$ and the early stages of the golah return following $538 \mathrm{BCE}^{27}$ Archaeological study and consultation with other relevant ancient texts form baseline expectations for the biblical texts. The limited goal, however, is to assess the literary/rhetorical purpose of the biblical texts themselves.

Second, differences between the DtrH and Chronicles can certainly be overplayed. Some differences may be attributed to textual transmission (i.e., the text of Samuel-Kings used by the Chronicler differs in places from the MT). ${ }^{28}$ The DtrH seems to be concerned with many of the theological/ideological issues prominent in Chronicles: centralized worship, the Davidic monarchy, covenant obedience, etc. Yet the differences are significant enough-particularly those differences that pertain to Benjamin - to warrant the assertion that the Chronicler has modified the DtrH's historiographical goals in light of intertribal relations in the Persian period. The question is one of degree: how much of the Chronicler's modification is due to tribal concerns?

Third, even if a certain ideological strand may be identified in the DtrH and/or Chronicles, it might not reflect a majority position within the Chronicler's Judahite context, nor can we say with certainty that implicit in the Chronicler's message is a historically accurate reflection of life in Yehud in his time. ${ }^{29}$ The Chronicler appears to have had a vision that extended far beyond his own setting. ${ }^{30}$

\footnotetext{
${ }^{27}$ Lipschits, "The History of the Benjamin Region under Babylonian Rule"; Blenkinsopp, "Benjamin Traditions," 644-645.

${ }^{28}$ See Knoppers, 1 Chronicles 1-9, 52-71; Japhet, I \& II Chronicles, 28-31; Klein, 1 Chronicles, 26-44.
} Knoppers cautions: "Text-critical studies do not free us from speculation about the Chronicler's use of earlier materials, but they do provide scholars with more precise tools with which to examine the respective textual traditions. On the one hand, caution is dictated in attributing tendentious intention to a Chronicles text whenever it differs from Genesis or Samuel, as the alleged change may be due either to the textual tradition represented by the Chronicler's Vorlage or to textual corruption. On the other hand, when neither of these two options seems likely, especially in dealing with the text of Kings, one can with confidence more clearly recognize those instances in which the Chronicler consciously made a change in his text. Employing the insights gained by text-critical studies of the Chronicler's sources affords scholars greater control over the available data and, hence, more precision and accuracy in determining the compositional technique and ideology of the Chronicler" (70-71).

${ }^{29}$ Louis C. Jonker, "Who Constitutes Society? Yehud's Self-understanding in the Late Persian Era as Reflected in the Books of Chronicles," JBL 127 (2008): 703.

${ }^{30}$ Sara Japhet argues: "For the Chronicler, 'the history of Israel' is the arena in which God's providence and rule of his people are enacted. By unveiling the principles which govern its history, a firm foundation is laid for the 


\subsection{STRUCTURE OF DISSERTATION}

This study will be divided into three parts. The first part will delve further into historical scholarship on Chronicles and the Persian period, including various historical, literary, and socialscientific methodologies that may be brought to bear on the question of the Chronicler's work in his socio-historical setting. One chapter will include a survey and preliminary synthesis of scholarly inquiry on the significance of the tribe of Benjamin. The second part will be primarily literary/rhetorical, focusing on the portraits of Benjamin in the DtrH and in Chronicles. Finally, a concluding section will draw conclusions from the synthesis of the historical and literary examinations of the Persian period, the DtrH, Chronicles, and Benjamin.

future existence of Israel" (I \& II Chronicles, 44). Japhet writes elsewhere (The Ideology of the Book of Chronicles and its Place in Biblical Thought; trans. Anna Barber; Winona Lake, IN: Eisenbrauns, 2009 [first English edition 1997; Hebrew original 1989]): "Chronicles is a comprehensive expression of the perpetual need to renew and revitalize the religion of Israel. It makes an extremely important attempt to affirm the meaningfulness of contemporary life without severing ties between the present and the sources of the past; in fact, it strengthens the bond between past and present and proclaims the continuity of Israel's faith and history" (404). 


\section{PART I}

\section{Chapter 2: Historical-Critical and Social- Scientific Methods}

The goal of this study is to examine what can be known about the Chronicler's historical situation based on the presentation of Benjamin in Chronicles. The thesis is that the Chronicler's presentation of Benjamin and "all Israel" in relation to Judah reflects an inclusive vision of Yehud's future.

This analysis will proceed in three stages: the establishment of a historical foundation from the evidence (what we think we know about the circumstances surrounding the production of the DtrH and Chronicles); a critical survey of the two works of literature with an eye to ideological or social-identity perspectives embedded within the texts; and a return to reconstruction of the historical context of the two works using the tools of social/political science. It is important to recognize the hermeneutical spiral as the analysis moves from historical criticism to literary criticism (ideological criticism, textual identities), and back to historical criticism (reconstruction). Principles of social identity formation and social/political science are applied in the literary and reconstructive phases of the study.

This chapter then sets forth the parameters and specific analytical principles that will be applied in this overall project of historical analysis and reconstruction. We will consider what sorts of critical methods could prove or disprove this thesis, and with how much certainty those conclusions could be reached.

The first section will discuss more generally the contributions of the historiographical enterprise to literary interpretation of ancient texts. Each of these two domains informs the other, and neither should be considered to the exclusion of the other. Particular attention is paid to the pitfalls of historical criticism pertaining to biblical studies.

The second section will consider different models of social identity, with particular focus on the context of the Persian province of Yehud. Collective identities have diverse origins and may manifest themselves quite differently over time. This section will also address the notion of textual identity, which connects the socio-historical theories of collective identity with written texts. The possibility of the mutual influence of collective identity and the texts of Persian-era Yehud upon one another will be an important question in this study. 
Finally, a third section will draw on two modern political theories with the goal of constructing a possible paradigm for the Chronicler's political goals. The notions of selectorate theory and heresthetic will be explored briefly in relation to the institutional setting(s) of the Chronicler.

\subsection{HISTORICAL CRITICISM AND LITERARY REPRESENTATION OF HISTORY ${ }^{1}$}

The ultimate purpose of this study is to contribute to the understanding of the Old Testament texts. $^{2}$ To that end, this study examines ideological tendencies within the literature of Chronicles and seeks to situate those tendencies within a specific socio-historical setting. The main area of exploration is Chronicles' presentation of the tribe of Benjamin and its implications for our understanding of Persian Yehud. Thus, historical and literary critical methods are of equal import (see discussion below of Dobbs-Allsopp, "Rethinking Historical Criticism"), subservient to the goal of aiding interpretation of the text itself. Rhetorical criticism combines both literary and historical inquiry: how does a text as literature and spoken word both reflect and shape the communities in which it was formed?

Responsible scholarly study of ancient texts will seek to integrate literary and historical criticism. Many scholars, depending on their interests and goals, prefer to emphasize one of these two critical realms but still use the other discipline to inform their work. The best historical scholarship is finely attuned to the meanings and rhetoric of texts as historical data, while the best literary scholars use external historical data to inform their understandings of the illocutionary force of texts.

${ }^{1}$ The following section develops and elaborates upon my unpublished thesis, "From Time-Bound to Timeless: The Rhetoric of Lamentations and Its Appropriation” (MTh thesis, Stellenbosch University, 2012), 6-15.

${ }^{2}$ Any undertaking of literary or historical criticism will force one to make subjective judgments. Though every attempt might be made to appeal to established "objective" fact, the danger of confirmatory bias is always present. Demonstrating similarity is simple; establishing correlation is complicated, and proving causation is still more difficult.

This study is conducted from a point of view that reveres the biblical texts as sacred communication from God through humans to humankind. However, this does not require that the biblical narratives be taken naïvely at face value-indeed, it does not seem that they were intended to convey "pure history" in a modern sense. For this author, the discernment of authorial intent, despite all the well-documented pitfalls and difficulties that come along with such a notion, is nevertheless the goal of biblical criticism.

Historical and archaeological studies are therefore necessary to discern what the biblical texts meant in their day, and in particular, how the authors/editors chose to present the information available to them. To discern critically and carefully what is actually preserved in the sacred texts is to honor the texts themselves and the deity who selfreveals in them. 
Scholarly study of the book of Chronicles is no exception. Certain ideas about the historical context of the production of the book have reached a broad consensus based on internal and external evidence-yet much is still speculation, since no "original autographs" exist with title page, date, and author (or editors) imprinted in the front. Responsibly-constructed theories concerning the historical context of Chronicles $^{3}$ follow a hermeneutical spiral, appropriating observations alternately from the realms of historical inquiry and literary criticism. For example:

- Based on external evidence, the historian argues that Chronicles was composed in Judah/Yehud and reached its final form sometime between $539 \mathrm{BCE}$ (the beginning of Cyrus's reign) and the early Hellenistic period (mid-third century BCE). ${ }^{4}$

- The literary critic then finds that the text of the book (internal evidence) places significant emphasis on the exclusivity of the Jerusalem cult.

- Armed with this "new" historical datum, the historian searches for other historical data that he might use to situate the Chronicler's work during some sort of conflict concerning the proper cultic center.

The sophisticated student of the Hebrew Bible will perform the roles of both the historian and the literary critic in this simple example. This sort of "trading off" of observations between the historical and the literary is the accepted process for critical study of ancient texts. This process of inquiry sometimes gives the illusion of greater precision than should be expected of it-or than is desired by its practitioners. Jonker observes:

It has been rightly pointed out that one cannot merely use biblical records such as Chronicles to "read off" what this flesh-and-blood society looked like. It has been emphasized equally, however, that historical books such as Chronicles reflect something of the self-understanding of this community. Although this self-understanding does not necessarily coincide with the flesh-and-blood society of that time, it nevertheless gives us a good impression of the processes of self-identification within the Yehudite community. ${ }^{5}$

Chronicles may be used as one set of historical data to be considered along with other data in reconstructions of Persian-era Yehud. Similarly, those other historical data inform our understanding of Chronicles.

${ }^{3}$ Or possibly, historical contexts, since the book may have been a composite work. The question of authorship and redaction will be addressed in the following chapter.

${ }^{4}$ Gary N. Knoppers, 1 Chronicles 1-9 (Anchor Bible Commentary; New York: Doubleday, 2004), 106.

${ }^{5}$ Louis C. Jonker, "Who Constitutes Society? Yehud's Self-understanding in the Late Persian Era as Reflected in the Books of Chronicles,” JBL 127 (2008): 703. 
The following sections will discuss the challenges of historical and literary study of scripture, and set forth general principles by which this study will be conducted.

\subsubsection{Historical Criticism}

This study engages the historical enterprise on two levels. First, the line of historical inquiry (subservient to biblical interpretation as stated above) involves in some sense "writing a history"or a very small portion of a history—of Yahwistic communities in the Persian period. Second, the present "historiographical" operation will entail a critical engagement with ancient historiography: the book of Chronicles. ${ }^{6}$

As a point of entry into the study of historiography, historical criticism and community identity, this section will briefly examine the contributions of three biblical scholars and a philosopher of history.

In an essay entitled, "Rethinking Historical Criticism,", Dobbs-Allsopp assesses the current state of biblical historical studies and some of the broad trends of the last two centuries. The problem he addresses is the wedge that has been driven between historical criticism and ahistoricist literary criticism, i.e., those who read literature just to get to history behind it and those who read literature with little regard for historical context. He states that his goal is "to provide a programmatic introduction to some of the major themes of historicist literary study and to explore how this body of work may help biblical scholars rethink historical criticism as a specifically literary method of study and reading." 8

Dobbs-Allsopp argues that knowledge is both constructed and textual. If the critic cannot bracket herself out of the process of interpretation, she must realize that "meaning is ultimately not found but made." 9 This fact becomes even more plain once she realizes that meaning is expressed in language, which is inevitably culturally (contextually) dependent. ${ }^{10}$ "There are no brute facts unmediated by some interpretive process."

Dobbs-Allsopp distinguishes between critical historicism and "radical historicism." Radical historicism has no hope that the blurred context of the author and the blurring context of the interpreter can be cleared to reveal anything meaningful. Radical historicism, then, is the rejection

${ }^{6}$ In this study the phrases "historiography" and "writing history" are used interchangeably. The term "history" may refer to "past events," or it may refer to $a$ specific presentation of the past - $a$ product of historiography.

${ }^{7}$ F.W. Dobbs-Allsopp, “Rethinking Historical Criticism,” Biblical Interpretation 7(1999): 235-71.

${ }^{8}$ Dobbs-Allsopp, "Rethinking Historical Criticism," 238.

${ }^{9}$ Dobbs-Allsopp, "Rethinking Historical Criticism,” 245.

${ }^{10}$ Dobbs-Allsopp, "Rethinking Historical Criticism," 247.

${ }^{11}$ Dobbs-Allsopp, "Rethinking Historical Criticism," 248. 
of the Cartesian eagerness for certainty, ${ }^{12}$ taken to its logical conclusion: "subjectivist free-play and nihilism." ${ }^{\prime 13}$ Dobbs-Allsopp counters that the radical historicist denial of history fails to provide a paradigm for those things that human beings know are historically real. Dobbs-Allsopp offers a critical historicism as the via media between the foundationalist position and radical historicism:

Critical historicism wants to ally a poststructuralist reading strategy with the historicist respect for the other and belief that the cultural and social milieu in which past literary works originated is likely to be relevant for understanding those works. ${ }^{14}$

The dangers on either side of this "middle way" are the tendency to give too much credence to the ancient context (objectivist determinism) and the tendency to discount the ancient context altogether (radical historicism). Critical historicism situates the reader as an equal, respectful dialogue partner with the text, rather than worshiping or denigrating the past.

Dobbs-Allsopp tries to offer a constructive way to do biblical studies in the wake of the postmodern critique of modernism. ${ }^{15}$ However, it is difficult to find any solace in his assertion that the only certainty that can be reached about the past is through a consensus of "experts":

A critical historicism ... makes no claims for correct meaning. Valid interpretations are those which prove politically efficacious in that they are able to persuade the larger interpretive community of their validity. There is nothing which necessitates a single correct interpretation. ${ }^{16}$

In his landmark work, Memory, History, Forgetting, Ricoeur outlines what he calls the three "phases" of the historiographical operation. The "documentary phase" is concerned with the gathering of information-from testimonies, documents (which are written testimonies) and archives. The second phase, the phase of "explanation/ understanding," answers the question, "Why did things happen like that and not otherwise?" The third phase is the "representative phase," in which the historian "offers a discourse to the readers of history." Of course, the historian

${ }^{12}$ Dobbs-Allsopp, "Rethinking Historical Criticism," 262-63.

${ }^{13}$ Dobbs-Allsopp, "Rethinking Historical Criticism," 251.

${ }^{14}$ Dobbs-Allsopp, "Rethinking Historical Criticism," 252.

${ }^{15}$ Dobbs-Allsopp's own body of work on Lamentations exemplifies an impressive attempt at this balance between literary studies such as his essay, "R(az/ais)ing Zion in Lamentations 2," in David and Zion: Biblical Studies in Honor of J.J.M. Roberts (ed. Bernard F. Batto and Kathryn L. Roberts; Winona Lake, IN: Eisenbrauns, 2004), 21-68; and historical studies such as Weep, O Daughter of Zion: A Study of the City-Lament Genre in the Hebrew Bible (Rome: Editrice Pontifico Istituto Biblico, 1993).

${ }^{16}$ Dobbs-Allsopp, "Rethinking Historical Criticism,” 260. 
immediately recognizes that these phases are not chronologically distinct; they are "interwoven with one another"; at each phase the historian will refer to the other two. ${ }^{17}$

The goal of historiography, Ricoeur states, ought to be "a true reconstruction of the past."18 Far from being naïve, Ricoeur as a well-read philosopher of history knows all the attendant difficulties of such an undertaking. Questions of epistemology are encountered at every phase.

Ricoeur posits that the goal of historiography is "the just allotment of memory." 19 History, by definition, cannot be repeated or experienced a second time; all that exists of it is an image in the mind $^{20}$ - a memory distinguished from imagination by the notion that the memory is a trace of something that was actually experienced. Memories thus define individual and collective identity. ${ }^{21}$ Being a "just" individual or society then, for Ricoeur, entails remembering and commemorating events as they were and according to their true significance. This is, of course, the whole problem with historiography, particularly Ricoeur's interpretive and representative phases: who is fit "justly to allot memory" and to represent memories accurately?

Ricoeur regards the modern historiographical enterprise as resting on a tacit "contract" between the writer and reader of an historical text:

[Both parties] agree that it will deal with situations, events, connections, and characters who once really existed, that is, before the narrative of them is put together, the interest or pleasure in reading coming as a kind of added surplus. The question now posed is whether, how, and to what degree the historian satisfies the expectation and promise conveyed by this contract. ${ }^{22}$

Ricoeur advocates narrative historiography, which had received significant criticism in the twentieth century. ${ }^{23}$ Historians and philosophers debated whether they should tell grand stories or short stories, collective stories or individual stories, and whether they should tell stories at all.

Narrative, Ricoeur argued, is simultaneously an essential part of historiography and its shortcoming. The narrative form "adds its modes of intelligibility to those of explanation/understanding; in turn these figures of style can be recognized to be figures of thought

${ }^{17}$ Paul Ricoeur, Memory, History, Forgetting (trans. Kathleen Blamey and David Pellauer; Chicago: University of Chicago Press, 2004), 136-37.

${ }^{18}$ Ricoeur, Memory, History, Forgetting, 137.

${ }^{19}$ Ricoeur, Memory, History, Forgetting, xv (Preface); cf. 86ff.

${ }^{20}$ Ricoeur, Memory, History, Forgetting, 21.

${ }^{21}$ Ricoeur, Memory, History, Forgetting, 78-80, $93 \mathrm{ff}$.

${ }^{22}$ Ricoeur, Memory, History, Forgetting, 275.

${ }^{23}$ For a discussion of narrative and its role in historiography, cf. Elizabeth Clark, History, Theory, Text: Historians and the Linguistic Turn (Cambridge, Mass.: Harvard University Press, 2004), 86-105. 
capable of adding a specific dimension of exhibition to the readability belonging to narratives." 24 But narrative form also betrays history's continuous nature by "giving the narrative a closure internal to the plot," even when the narrator tries to "deceive [the readers] through strategies aimed at a kind of non-ending. In this way the very act of recounting comes to split off from that 'real' thereby put in parentheses. ${ }^{, 25}$ But the representation of history is unavoidably narratival, since narrative is the only guarantee of meaning. ${ }^{26}$

There are two basic obstacles to the study of ancient historiography: that it is ancient, and that it is historiography. Almost any assessment of ancient representation of history by contemporary standards will find much to be desired. Rather than holding the ancient historian to the same "contract" by which the modern writer and reader of history are bound, the modern historian must seek to understand the expectations of the author and reader of the ancient historiographical text. By working through Ricoeur's three phases in our examination of ancient history, we are able to assess the représentance of history ${ }^{27}$ in the literature of Persian Yehud.

The Hebrew Bible is a collection of memories that have defined the identities of several communities (Jewish and Christian) throughout history. It should be emphasized that the consideration of the Hebrew Bible as "history" should not be limited to the narrative books. Ben Zvi, for example, argues that the books of the prophetic collection are interpretive and representative of history insofar as they both appeal to and attempt to shape collective memory. ${ }^{28}$

In an essay entitled, "The 'Sacred' Text and the Community," ${ }^{29}$ Ricoeur addresses the role of a sacred text in shaping the identity of religious community. The authority of a text, he explains, is reciprocally related to the founding of the community: the text is recognized and canonized by the community as foundational, but then the text shapes the continuing identity of the community. ${ }^{30}$ In Jewish and Christian traditions, the text then takes on a new dynamic when it is spoken and preached in the community: "Preaching is the permanent reinterpretation of the text that is regarded as grounding the community; therefore, for the community to address itself to another text would be to make a decision concerning its social identity." ${ }^{, 31}$

${ }^{24}$ Ricoeur, Memory, History, Forgetting, 276.

${ }^{25}$ Ricoeur, Memory, History, Forgetting, 276.

${ }^{26}$ Clark, History, Theory, Text, 90.

${ }^{27}$ Ricoeur, Memory, History, Forgetting, 235.

${ }^{28}$ Ehud Ben Zvi, "On Social Memory and Identity Formation in Late Persian Yehud," in Texts, Contexts and Readings in Postexilic Literature (ed. Louis C. Jonker; Tübingen: Mohr-Siebeck, 2011), 104.

${ }^{29}$ Paul Ricoeur, "The 'Sacred' Text and the Community," 68-72 in Figuring the Sacred: Religion, Narrative and Imagination (ed. Mark I. Wallace; Minneapolis: Fortress Press, 1995).

\footnotetext{
${ }^{30}$ Ricoeur, "The 'Sacred' Text and the Community," 69.

${ }^{31}$ Ricoeur, "The 'Sacred' Text and the Community," 70.
} 
This study is not concerned as a matter of first importance with the historicity of these images-whether they are "memories" or "imaginations"- so much as their function within the communities. Secondarily, however, we understand the interpretive and rhetorical goals of the texts by attempting to distinguish "memory" from "imagination"- a complex but crucial task.

An extreme skepticism would regard all representation of the past in the Hebrew Bible as not "standing for" an actual past—i.e., biblical historiographies are fictions constructed to create collective consciousness. ${ }^{32}$ Such complete skepticism almost certainly overstates the ability of collective memory to be manipulated, especially within only a few generations. ${ }^{33}$ On the contrary, memory is shaped gradually, "along the margin," within accepted boundaries. ${ }^{34}$ Rather than creating a whole new set of memories and traditions, the exilic and postexilic authors sought to allot/apportion/align memory appropriately—justly, from their perspectives. The ancient authors perceived themselves as faithful (in the dual sense of "representing what actually happened" and "from a faith perspective") commemorators of Israel's past.

How did ancient authors create and adapt material to shape their own communities' identities? What was the nature of the tacit "contract" between ancient writer and reader, particularly in the Second Temple Period? In a monograph on the Pentateuch, Ska outlines five well-known principles for understanding and interpreting ancient literature. ${ }^{35}$

First, for the ancients authority is rooted in antiquity. "It is clear...that the texts of the Pentateuch want to show the antiquity of Israel's traditions: Israel is older than the Monarchy and older than the Conquest of the land....Antiquity is needed to prove the worth of Israel's traditions to the nations." ${ }^{36}$ Literature set in the exilic and postexilic periods appeal to ancient traditions "to show that Israel's God was not at all inferior to the powerful divinities of the conquerors. ${ }^{37}$ The

\footnotetext{
${ }^{32}$ Thomas L. Thompson, The Mythic Past: Biblical Archaeology and the Myth of Israel (New York: Basic
} Books, 1999); Philip R. Davies, In Search of “Ancient Israel” (Sheffield: JSOT Press, 1992); Keith W. Whitelam, The Invention of Ancient Israel: The Silencing of Palestinian History (New York: Routledge, 1996); Niels Peter Lemche, The Israelites in History and Tradition (Louisville: Westminster John Knox Press, 1998).

${ }^{33}$ Lawrence Schiffman, From Text to Tradition (Hoboken, NJ: Ktav Publishing House, 1991), 19.

${ }^{34}$ Ben Zvi, "On Social Memory," 115.

${ }^{35}$ Jean-Louis Ska, Introduction to Reading the Pentateuch (trans. Sr. Pascale Dominique; Winona Lake, IN:

Eisenbrauns, 2006), 165-83.

${ }^{36}$ Ska, Pentateuch, 169.

${ }^{37}$ Ska, Pentateuch, 167. Michael Fishbane (Biblical Interpretation in Ancient Israel; New York: Oxford University Press, 1986) explains this process at work in Jewish tradition (1-19). 
genealogical introduction to Chronicles displays authorial/editorial interest in the antiquity of Israel's traditions and the universal sovereignty of Israel's deity. ${ }^{38}$

A second principle is the tendency to avoid eliminating from tradition—only additions may be made. This is why contradictory traditions stand in tension, for example, in the legal material of the Pentateuch: legal practice changes, but the sacred word is still preserved. While this is true of individual edited and redacted texts of the Hebrew Bible, the Hebrew Bible itself is a prime example: changing attitudes and traditions are preserved as a single canon. This axiom of "conservation" may indicate that the Chronicler, given his significant omissions from the Vorlage, intended his work to supplement Samuel-Kings, not to supplant it as scripture. ${ }^{39}$

Third, the past is preserved because it has ongoing implications for the present. Deuteronomy 5:3 is an example within the Pentateuch: the covenant is said to have been "made," not "renewed," with the second generation preparing to enter the Promised Land. Exilic and postexilic restoration texts constantly appeal to the past as a basis for action in the present; for example, Ezra-Nehemiah casts the golah return from Babylon as a second exodus. ${ }^{40}$ This principle is the impetus for inquiry into the authorial intent and reception of Chronicles in the late Persian period.

Fourth, because writing was an expensive process, only that which was very important was preserved. This principle is somewhat in tension with the second principle (conservation). These two principles together raise interesting historical and hermeneutical questions for the synoptic study of Chronicles and its sources: Chronicles, though largely comprised of previous traditions, was nonetheless received and retained as scripture. ${ }^{41}$

${ }^{38}$ However, Knoppers notes that the Chronicler, by placing the Hebrews' eponymous ancestor, Eber, late in the Table of Nations and geographically in the East, tacitly "admits, much like earlier biblical writers before him, that Israel was a relative latecomer to the stage of world history," and that "he does not see Israel as indigenous to its land." The Chronicler, like the author of Jubilees, could have modified the story to make the land of Canaan part of Shem's allotment which was usurped by Canaan (Hammite)_but he does not. See Knoppers, "Shem, Ham and Japheth: The Universal and the Particular in the Genealogy of Nations," in The Chronicler as Theologian (ed. M. Patrick Graham, Steven L. McKenzie, and Gary N. Knoppers; New York: T\&T Clark, 2003), 28-30.

${ }^{39}$ But see also the discussion below of text production as a dynamic social force rather than merely a conservative one: Nathaniel B. Levtow, “Text Production and Destruction in Ancient Israel: Ritual and Political Dimensions," in Social Theory and the Study of Israelite Religion: Essays in Retrospect and Prospect (ed. Saul M. Olyan; Atlanta: SBL, 2012), 111-139.

${ }^{40}$ J. Gordon McConville, "Ezra-Nehemiah and the Fulfillment of Prophecy,” VT 36 (1986): 205-24. Cf. K. Koch, "Ezra and the Origins of Judaism,” Journal of Semitic Studies 19 (1974): 173-97.

${ }^{41}$ See the helpful discussion of these questions by Louis C. Jonker in "Reforming History: The Hermeneutical Significance of the Books of Chronicles," VT 57 (2007): 21-44. 
Finally, since ancient texts were written in context, other works from the same period may offer insight into the methods and content of the biblical texts. However, the value of such comparative study can be overestimated. The Hebrew Bible is a collection of Jewish religious texts substantially from the Persian period (with exceptions); for better or worse, these are the only such texts we have. Comparison to non-Jewish religious texts of the period, or to later Jewish texts, is helpful, but only to a point.

The relationship between "biblical Israel" and "ancient Israel" has been the subject of much debate in the past forty years. ${ }^{42}$ After the breakdown of the so-called "Albright consensus," historians have been sometimes divided into "minimalists" and "maximalists" with regard to the reliability of the biblical texts. Grabbe notes that these labels are frequently pejorative and represent a polarized caricature of what is really a wide spectrum of views. ${ }^{43}$

Like Dobbs-Allsopp and Ricoeur, Grabbe wrestles with the postmodern and minimalist critiques of history. ${ }^{44}$ His perspective could perhaps be called a sort of critical realism: ${ }^{45}$ acknowledging that historical knowledge is limited and perspectival, yet still holding the past in regard as a worthy "other" to be respectfully but critically examined. History is not simply "a discussion of problems and possibilities," but involves making "subjective decisions about sources and interpretation." Speculation, however, should be "clearly labeled and its basis indicated." 46 Grabbe introduces five principles for writing ancient history: ${ }^{47}$

${ }^{42}$ Studies include: Philip R. Davies and Diana V. Edelman, eds., The Historian and the Bible: Essays in Honour of Lester L. Grabbe (New York: T\&T Clark, 2010); William G. Dever, Who Were The Early Israelites, And Where Did They Come From? (Grand Rapids: Eerdmans, 2003); Israel Finkelstein and Neil Asher Silberman, The Bible Unearthed: Archaeology's New Vision of Ancient Israel and the Origin of Its Sacred Texts (New York: Free Press, 2001); Lester L. Grabbe, Ancient Israel: What Do We Know and How Do We Know It? (London: T\&T Clark, 2007).

${ }^{43}$ Lester L. Grabbe, A History of the Jews and Judaism in the Second Temple Period, Volume 1: Yehud: A History of the Persian Province of Judah (London: T\&T Clark, 2004), 12.

${ }^{44}$ See Grabbe's numerous contributions, including: Ancient Israel: What Do We Know and How Do We Know It?; History of the Jews and Judaism Vol. 1, 2-20; "Jewish Historiography and scripture in the Hellenistic Period," 129155, and "Who Were the First Real Historians? On the Origins of Critical Historiography," in Did Moses Speak Attic? Jewish Historiography and scripture in the Hellenistic Period (ed. Lester L. Grabbe; Sheffield: Sheffield Academic Press, 2001), 156-181; and “"The Exile' Under the Theodolite: Historiography as Triangulation,” in Leading Captivity Captive: 'The Exile' as History and Ideology (ed. Lester L. Grabbe; Sheffield: Sheffield Academic Press, 1998), 80100 .

${ }^{45}$ The editors (Davies and Edelman) of a Festschrift presented to Grabbe (The Historian and the Bible) suggest that he would embrace the label "pre-postmodern" (xiv).

${ }^{46}$ Grabbe, History of the Jews and Judaism Vol. 1, 2-3.

${ }^{47}$ Grabbe, History of the Jews and Judaism Vol. 1, 14-16. 
1. Historical knowledge is possible, but our access to the past is only indirect.

2. All our historical knowledge is contingent and provisional.

3. Although objectivity in the scientific sense is not possible, 'qualified objectivity' or some similar position is still possible in historical study.

4. The ultimate goal is a total history, which takes into account all aspects of the past.

5. We must use all potential sources.

Grabbe outlines some of the difficulties with writing a history of the Persian period, particularly the lack of direct sources from this period. His focus is the primary material as far as possible. He tries carefully to utilize the tools of the social sciences in his examination, recognizing the pitfalls of such an attempt. ${ }^{48}$ Like most critical historians, Grabbe finds that "certain sorts of data in the biblical text are more likely (a priori) to be reliable than others." ${ }^{49}$ The texts of the Hebrew Bible pertaining to the Persian period are mostly (but not exclusively) written from perspectives that accept the primacy of the Jerusalem cult, which came to dominate the religious life of Yehud. Establishing minority perspectives from hostile texts can be tricky.

An approach that discredits the biblical texts as historical sources merely on the grounds that religious communities — past and present—have considered the texts to be sacred, would be methodological folly. ${ }^{50}$ Suspicion of the theological and ideological presentation of facts is warranted, from the standpoint of critical historiography. However, the biblical texts should not be subject to fiercer scrutiny than other ancient texts. ${ }^{51}$

\subsubsection{Historical Reconstruction: Limitations}

There are several limitations on the reconstruction of the context of Chronicles that must be recognized. Our understanding of these limitations is itself the fruit of the historical enterprise.

${ }^{48}$ Grabbe, History of the Jews and Judaism Vol. 1, 16-17.

${ }^{49}$ Grabbe, History of the Jews and Judaism Vol. 1, 14 (parenthesis original).

${ }^{50}$ It is important to acknowledge my own Christian perspective in an historical approach to the Hebrew Bible. The fragmentation of second temple Judaism has been sometimes used to advance a Christian narrative, i.e., the New Testament's presentation of Jesus of Nazareth as the fulfillment of the restoration hopes of the exilic and second temple communities. The earliest followers of Jesus self-identified as true Israel, forged in a new exodus—not unlike many other Persian- and Hellenistic-era Jews.

The purpose in acknowledging a Christian perspective is to strengthen this study by anticipating and diffusing potential criticism.

${ }^{51}$ Hans M. Barstad, "The Strange Fear of the Bible: Some Reflections on the 'Bibliophobia' in Recent Ancient Israelite Historiography," in Leading Captivity Captive: 'The Exile' as History and Ideology (ed. Lester L. Grabbe; Sheffield: Sheffield Academic Press, 1998), 120-127. 
First, any ideological concerns that may be discerned in Chronicles' representation of the past most likely reflect continuing issues within the community, based on the fact that Chronicles "caught on" as sacred scripture. In other words, a strictly time-bound work that addressed only limited (con)temporary concerns might not have found wider acceptance over time-especially if much of the Chronicler's material was contained within writings that were already considered sacred. ${ }^{52}$ Any postulated set of ideological strands in Chronicles would need to fit a broader set of socio-historical contexts over a period of time, or propose an alternative explanation for the continued acceptance and promulgation of Chronicles as scripture. ${ }^{53}$

Second, because the Chronicler adapted preexisting material for his purposes, he was constrained to some degree by the tradition in which he stood. Of course, the Chronicler did not appear to have been subject to the constraints of modern understandings of the roles of author, historian and theologian-his completed work is original and unique in character. But the fact that he copied, modified and consciously deviated from his source indicates some level of loyalty to previous scripture. Ideological- and rhetorical-critical approaches to Chronicles must account for these constraints on the Chronicler's rhetoric and message- - he was not completely free, perhaps by his own choosing.

Third, though the issues addressed in Chronicles will likely reflect contemporary concerns to some degree, the Chronicler's ideology might not reflect a majority position in his time. This consideration will affect any postulation of a socio-historical context for the book. The Chronicler's perspective as an elite in a colonial society ${ }^{54}$ bears some relation to the sociology of knowledge within Persian Yehud, but it cannot be a one-to-one correspondence:

Only a very limited group of people in any society engages in theorizing, in the business of 'ideas,' and the construction of Weltanschauungen. But everyone in society participates in its 'knowledge' in one way or another. Put differently, only a few are concerned with the theoretical interpretation of the world, but everybody lives in a world of some sort. Not only is the focus on theoretical thought unduly restrictive for the sociology of knowledge, it is also unsatisfactory because even this part of socially available 'knowledge' cannot be fully understood if it is not placed within the framework of a more general analysis of 'knowledge.' 55

${ }^{52}$ In "From Time-Bound to Timeless: The Rhetoric of Lamentations and Its Appropriation," I explored the literary features of the book of Lamentations that allowed it to endure as sacred scripture long after its immediate sociohistorical context, i.e., the templeless age.

${ }^{53}$ The issue of the authorship and promulgation of Chronicles will be addressed in the next chapter.

${ }^{54}$ Ben Zvi, “On Social Memory,” 95-96.

${ }^{55}$ Peter L. Berger and Thomas Luckmann, The Social Construction of Reality: A Treatise in the Sociology of Knowledge (New York: Anchor Books, 1967 [1966]), 15. 
Chronicles contains the ideas of a member (or members) of the religious elite, which do not necessarily correspond to the understanding of the community at large. However, the Chronicler's worldview and the worldviews of his audience certainly shared common elements. The Chronicler no doubt tailored his work to meet the interests and concerns of his audience in order to achieve his own rhetorical goals.

\subsection{IDENTITIES IN PERSIAN YEHUD: COMMUNITIES AND TEXTS}

This section will consider theories of community identity and social memory. The issues surrounding the key question of the reciprocal relationship between community identity and the text of Chronicles will be explored: to what extent do the community and text influence one another?

\subsubsection{Community Identity}

This sub-section will consider first the limitations inherent in an ethnic theory of community identity, and then other models of identity that would be necessary in determining the relationship between Persian-era Yehud and the text of Chronicles.

\subsubsection{Ethnic Identity}

The nature of Jewish identity has been a subject of much debate and disagreement from antiquity until the present. Questions of religion, culture and ethnic background swirl together to form a "Neapolitan" debate about who is in, who is out, and who cares. ${ }^{56}$ Geopolitical events of the twentieth century, particularly the Holocaust and the establishment of the nation-state of Israel, have brought this question to the forefront of public debate.

Jewishness is often defined in modern discourse as an ethnic designation. However, sociological studies have demonstrated the unstable, indefinite and fluid nature of ethnic identities. $^{57}$

Ethnic identity is based in an understanding of common origin. This "social memory" creates and maintains the boundaries that form community cohesion:

${ }^{56}$ See Morris N. Kertzer, What Is a Jew? (New York: Macmillan Publishing Co, 1975); Shaye J. D. Cohen, The Beginnings of Jewishness: Boundaries, Varieties, Uncertainties (Berkeley, CA; University of California Press, 1999).

${ }^{57}$ Fredrik Barth, "Introduction," in Ethnic Groups and Boundaries: The Social Organization of Culture Difference (ed. Fredrik Barth; London: Allen \& Unwin, 1969), 9-37; Anthony D. Smith, The Ethnic Revival (Cambridge: Cambridge University Press, 1981). 
Surely, without some form of shared memory, there could be no sense of social continuity through time (whether short or long) and therefore no communal reproduction or even simply maintenance. All historical communities — even at the basic level of family and kin-are imagined communities based on a shared memory. They are brought together not only by sharing memories about a shared past, but also by an underlying shared approach to and about constructing memories. ${ }^{58}$

Some social memories have created community cohesion has resulted in the transformation of the community into a "national" designation:

Even well-established ethnic communities encounter barriers in their quest for national status. They may be able to present a united community and a centuries-long history; but the institutions which are the result of the very length and depth of that history may block the transformation of an ethnic community into a 'nation', and hold back the acquisition of a national status. ${ }^{59}$

A.D. Smith also finds that ethnic identity manifests itself differently among Diaspora minority communities that are tied to a particular homeland, than in minorities that have no such connection or only a weakened connection:
One of the characteristics that distinguish ethnic categories or communities from nations is precisely the territorial dimension: a nation, by definition, requires a 'homeland', a recognised space and ecological base, if only to ensure cohesion and autonomy and the rights of citizenship, whereas an ethnic community, let alone category, can maintain its sense of belong or its distinctive cultural characteristics without such a territorial base. ${ }^{60}$

The establishment of the modern state of Israel - though dependent upon geopolitical and economic factors-nevertheless bears witness to the power of common memory in creating social cohesion. ${ }^{61}$ But ethnicity is defined relative to the perceived "other(s)." Jews of many different cultural backgrounds, linked by a myth of origin, emigrated to the land of Palestine, bringing cultural traditions from all over the world. Many Americans of diverse African ancestry share a story of "origin" (captivity and slavery) that ties them together. Anglo-Americans, among the first Europeans to settle North America, demonstrated a pattern of prejudice toward waves of subsequent European immigrants, followed by gradual assimilation of those immigrants as new groups immigrated.

\footnotetext{
${ }^{58}$ Ben Zvi, "On Social Memory,” 100.

${ }^{59}$ Smith, The Ethnic Revival, 69.

${ }^{60}$ Smith, The Ethnic Revival, 69-70.

${ }^{61}$ See also Anthony D. Smith, The Ethnic Origins of Nations (Oxford: Blackwell, 1986).
} 


\subsubsection{Yehudite Identity in the Persian Period}

The instability and fluidity of ethnic identity is evident in ancient cultures as well, and Achaemenid Yehud is no exception. Berquist ${ }^{62}$ and Jonker ${ }^{63}$ have both provided succinct and helpful discussions of several approaches to the difficult question of Yehudite community identity in the Persian period. Berquist's discussion categorizes different sorts of identity, while Jonker focuses on the complexity of community identification on multiple strata or dimensions.

Berquist initially considers the notion of ethnic identity in this period, which is "the classic assumption of early and modern biblical scholarship." ${ }^{64}$ An ethnic theory of identity has the benefit of reflecting the apparent interests of many of the ancient texts-as evidenced by the biblical genealogies and the stories of ethnic distinction/conflict-and it also "creates a clear connection between the ancient biblical story and the contemporary world; the story of Judah is not just a story of ancient people but a story of ancestors and thus, for some people today, a story of their own ethnicity." ${ }^{65}$ However, an ethnic theory of identity is recognized by scholars as problematic because of the ambiguity of much of the evidence available, including archaeological evidence ("archaeologists have difficulty discerning the ethnicity of a given artifact's maker or user") and epigraphic evidence (the etymology of a name may not reflect the actual lineage of a person). Furthermore, mixed marriages, particularly in the case of Persian Yehud, made ethnic distinctions "increasingly problematic." ${ }^{66}$ Ethnicity is recognized as a primarily modern concept, and modern scholarship cannot impose its own categories on ancient evidence: "At the very least, scholars should insist that ethnicity is not an objective category measurable through genealogy. Recent scholarship on ethnicity emphasizes the subjective character of ethnic boundaries; they are largely products of the mind and imagination." 67

\subsubsection{Other Models of Identity}

Berquist notes that identity may also be understood as nationality, membership in a political entity. This model has the advantage of being objective, in that persons could be identified as belonging to a polity or region. "Furthermore, it allows for a simple understanding of the

${ }^{62}$ Jon L. Berquist, "Constructions of Identity in Postcolonial Yehud," in Judah and the Judeans in the Persian Period (ed. Oded Lipschits and Manfred Oeming; Winona Lake, IN: Eisenbrauns, 2006), 53-66.

${ }^{63}$ Louis C. Jonker, "Engaging with Different Contexts: A Survey of the Various Levels of Identity Negotiation in Chronicles," in Texts, Contexts and Readings in Postexilic Literature (ed. Louis C. Jonker; Tübingen: Mohr-Siebeck, 2011), 63-93.

\footnotetext{
${ }^{64}$ Berquist, "Constructions of Identity," 54.

${ }^{65}$ Berquist, "Constructions of Identity," 55.

${ }^{66}$ Berquist, "Constructions of Identity," 55.

${ }^{67}$ Berquist, "Constructions of Identity," 55; Barth, "Introduction;" Smith, The Ethnic Revival.
} 
relationship between Persian identity and Judean identity; the latter is a subset of the former, since both are political terms." ${ }^{\prime 68}$ The disadvantage of this model is that it fails to explain much of the biblical and historical evidence of those who identified as Jews but who lived outside of Yehud.

Jonker similarly notes the flexibility and ambiguity of both the ethnic and national aspects of identity. He argues that identity in Yehud must be understood on at least four dimensions, three of which are pertinent to ethnic and national designation: the Persian imperial dimension, the regional provincial dimension, and the inner-Yehudite dimension. ${ }^{69}$ A subgroup might define itself on each of these dimensions in relation to a perceived "other": as descendents of Judah in contrast to Benjaminites; as Yehudites in contrast to Samarians or other peoples of the Ebir-nari satrapy; or as a people-group of the Persian Empire in contrast to the Greeks. ${ }^{70}$ The key features of these national and ethnic identities are flexibility and complexity.

Berquist next turns to the notion of identity understood as religion: "thus, to be Judean was to participate in a Yahwistic cult." ${ }^{, 71}$ He points to the widely-held scholarly and popular view that Jewish identity shifted from a primarily national-political designation to a religious designation during the exile and the Persian period, when Israel as a distinct polity ceased to exist. ${ }^{72}$ Yet Berquist finds an exclusively religious model of identity to be increasingly problematic, given the blurring of religious and political institutions in the Persian period, and given the apparent plurality of religious views among self-identified Jews. ${ }^{73}$ He concludes:

The national and religious theories of identity share a deeper problem, in that they are both top-down theories. As such, they develop easy criteria for our discernment about identity, but they are unlikely to reflect how ancient Judeans thought of themselves. These theories emphasize objective group membership and do not easily recognize that identity operates simultaneously as external, observable reality as well as internal, personal reality. ${ }^{74}$

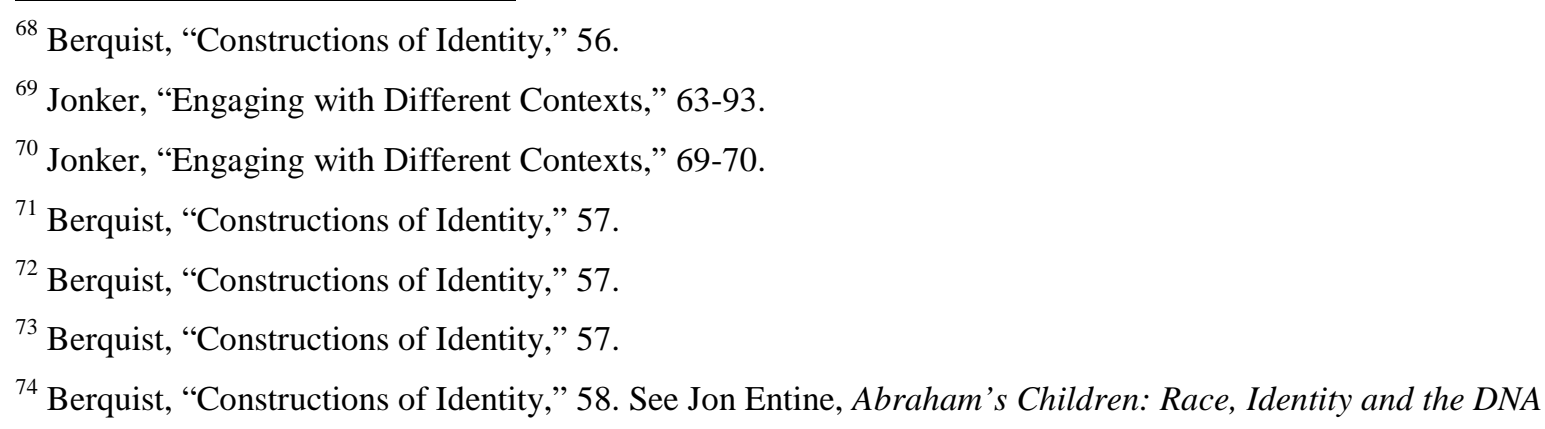
of the Chosen People (New York: Grand Central Publishing, 2007) for a contemporary example of the strength of the construct of ethnicity to overturn religious beliefs and practices. Entine tells the story (14-30) of an extended family of "Hispanos" (Hispanics of Mexican-American ancestry) who discover supposedly Jewish genetic markers in their family. While most of these "crypto-Jews" maintained their Roman Catholic faith, a few converted to Judaism based on this new discovery. Whether or not there is in fact a discernibly "Jewish gene" (the notion is quite controversial; Cohen [The Beginnings of Jewishness, 10], for example, is unconvinced), this story shows both the flexibility and the power of perceived ethnic identity. 
Jonker likewise notes the flexibility and complexity of religious identity during this period. He presents a fourth dimension of social categorization: the cultic context of Yehud. For example, even those Yehudites who identified with the Jerusalem cult were further categorized into propriestly and pro-Levitical factions, and even priestly partisans supported different priestly families. $^{75}$

These different constructs of identity—ethnicity, nationality, religion—are difficult to untangle in certain communities, since each is a component of the boundaries that define a community. If, in fact, a group's boundaries are more important to its identity than the internal consistency and continuity of the "defining" characteristics, ${ }^{76}$ then the group may strengthen those boundaries by highlighting several defining characteristics rather than just one. Jewish communities throughout history have quite flexibly emphasized ethnicity, religion or nationality to varying degrees depending on the needs of the community at the time. ${ }^{77}$

Berquist presents a fourth approach to identity that he calls role theory. This "bottom-up" sociological model focuses on "[describing] how individual people take on distinct roles in society, integrating functions and self-understandings." 78 This model, though it has the advantage of allowing for more nuanced descriptions of individuals' self-identities, complicates the question of identity significantly, since an individual may take on several distinct roles in society. "Role theory allows for the explanation of observed social behaviors, but the number of social roles is always too great to allow for the reconstruction of a society." ${ }^{79}$ Role studies are also vulnerable to the errors of essentialism - "the assumption that roles define all of life or render behavior definite and predictable, as if roles determined a person's essence"-and functionalism—-"[the assumption] that society is the sum total of the additive roles undertaken by its participants." ${ }^{\circ 0}$

Berquist applies a postmodern critique to these four models, adopting certain strengths of each model-particularly role theory_into a chaos theory model of social interactions of which the exposition of individual identities is only one component. This chaos theory acknowledges the nonlinearity, unpredictability and fluidity of society, but seeks to "discern patterns within the chaotic randomness and the indeterminability of individual particles. ${ }^{\prime 81}$ The patterns, however, are not primarily "categories into which we could place different types of societies or social situations,"

\footnotetext{
${ }^{75}$ Jonker, "Engaging with Different Contexts," 71-74.

${ }^{76}$ Cohen, The Beginnings of Jewishness, 5.

${ }^{77}$ See Cohen, The Beginnings of Jewishness, especially 341-349.

${ }^{78}$ Berquist, "Constructions of Identity," 58.

${ }^{79}$ Berquist, "Constructions of Identity," 58.

${ }^{80}$ Berquist, "Constructions of Identity," 59.

${ }^{81}$ Berquist, "Constructions of Identity," 60.
} 
but rather, "patterns of force" in conflict—for example, autonomy, imperialism, religious impulse, etc. $^{82}$

Thus, Berquist argues that identity in Persian Yehud must be sought in the processes of imperialization and resistance, rather than in the statuses of imperialism and autonomy. It is more appropriate to speak "not of identity but of identity formation." 83 Berquist acknowledges the inherent difficulty of this sort of inquiry, given that history deals with facts, discrete points of information, which it must interpret and from which it must interpolate the presence of societal forces. He concludes:

\begin{abstract}
Understanding Judean identity formation involves a complex analysis of multiple social levels with attention to numerous processes in which people internalize the forces of imperialization and decolonization. As social agents, these self-identifying Judeans together constructed a story of the development of Judah during the Achaemenid Period, as they turned their role scripts into social action and deployed themselves in patterns of ethnicity, politics, and religion, as well as myriad other complex social patterns. Such attention to identity formation necessitates deeper and more critical understandings of the forces of imperialization and decolonization and the way that these forces shape identity and difference within societies. ${ }^{84}$
\end{abstract}

Jonker underscores the multidimensionality of self-categorization in Persian Yehud. The history of this period reflects a process of self-identification not within a single socio-historical level but within multiple levels-imperial, regional, ethnic, and cultic. ${ }^{85}$ Reflecting on the evidence of this process in Chronicles, Jonker argues: "It is important to emphasise that these levels never functioned in isolation. The inhabitants of Yehud, and particularly the literati who were responsible for the writing of another historiography, the books of Chronicles, were exposed to all these contexts, and were active participants in all of them." 86

The move toward a model of identity formation along multiple dimensions reflects the changes in the discipline of sociology and its rippling effects on the other social sciences. History, like other social scientific disciplines, still deals with the single datum, the discrete fact and the unique event or individual — the historian must interpolate a force, movement or trajectory. The next section will explore the different sorts of ways that texts (focusing on Chronicles) reflect social identities through the presentation of individual data and the ways that historians and literary critics attempt to use those data in reconstructing those trajectories of identity formation.

\footnotetext{
${ }^{82}$ Berquist, "Constructions of Identity," 61.

${ }^{83}$ Berquist, "Constructions of Identity," 63 (emphasis added).

${ }^{84}$ Berquist, "Constructions of Identity," 64-65.

${ }^{85}$ Jonker, "Engaging with Different Contexts," 63, 74, 91.

${ }^{86}$ Jonker, "Engaging with Different Contexts," 73-74.
} 


\subsubsection{Texts and Textual Identities}

Texts are the most important witnesses to the formations of identity during the period in question. Texts such as the books of the Hebrew Bible provide witness to the process of identity formation on two dimensions that are often difficult to distinguish. These texts are products of communal identity, but are also intended to influence communal identity. ${ }^{87}$

The study of "textual identities" emphasizes this interplay between the social identities reflected in a text and that text's own influence on understandings of social identity. This section considers the ways in which the texts and contexts of the Persian era influenced one another, and then focuses on several examples of this sort of interplay in Chronicles.

Historical consideration of the literary production of Persian Yehud begins with the scribal class and scribal culture. Scribes played a crucial role in the composition, editing, preservation and promulgation of texts, ${ }^{88}$ so texts of prominence and high literary quality would commonly relate to- - and be primarily the production of - the scribal class. Scribal activity required significant material resources, and therefore also reflects its patronage. ${ }^{89}$ Ben Zvi notes:

\footnotetext{
Given (a) the size of the community, (b) the fact that the maintenance of a literati group required social resources, (c) the likely role of the Jerusalem temple in supporting the production of highly sophisticated Jerusalem-centred texts and their authorships and (re)readerships, and (d) that the literati's Jerusalem-centred ideology promoted and was fully consistent with the historical process that led to an incipient Jerusalemite temple in a Benjaminite-centred early Persian Yehud gaining the status of the central institution that it became already by the mid-/late Persian period, it is reasonable to assume that the collective memory of the community was not far removed from that of the literati. $^{90}$
}

His argument is that the Jerusalemite scribal production reflects to a certain degree the collective memory of the temple's patrons_-including perhaps Benjaminite elites—and is oriented toward utilizing and shaping that collective memory.

Levtow suggests that recent developments in the understanding of text production in the ancient world may illumine the process of Israelite scribal activity. ${ }^{91} \mathrm{He}$ argues that the old models

\footnotetext{
${ }^{87}$ Ricoeur, "The 'Sacred' Text and the Community," 69.

${ }^{88}$ See especially the recent contributions by Karel van der Toorn, Scribal Culture and the Making of the
} Hebrew Bible (Cambridge: Harvard University Press, 2009), and David M. Carr, The Formation of the Hebrew Bible: A New Reconstruction (New York: Oxford University Press, 2011).

\footnotetext{
${ }^{89}$ Ben Zvi, “On Social Memory,” 95-96.

${ }^{90}$ Ben Zvi, “On Social Memory,” 95-96.

${ }^{91}$ Levtow, "Text Production and Destruction," 112.
} 
of orality and literacy used in biblical studies_-models that considered oral tradition as more dynamic and enscripturation as freezing that discourse - need to be modified based on the recent discoveries of social anthropologists and historians. ${ }^{92}$

Levtow emphasizes the interplay between ritual and text. He compares the misunderstanding of the ritual effects of inscripturation to that of the creation of a cult image:

When texts and images are unmoored from the social contexts of their production and reception, they become mute objects with no fundamental, intersubjective relation to people. Such an understanding of text production posits an Israelite scribal culture in which words and things possess power and meaning independent of any particular social world and cultural order. ${ }^{93}$

Building on the work of Catherine Bell ${ }^{94}$ and others, Levtow calls textualization "a form of ritualization," which is "not simply a conservative force, [but] also a socially transformative force." $" 95$ This opens up new ways of understanding the purpose and effect of writing in ancient Israel. ${ }^{96}$ Bell writes, "By viewing the text as an entity that merely expresses a particular perspective on its time, we may miss how the text is an actor in those times." ${ }^{97}$ In Levtow's estimation, Bell's model of the interplay between "textualization" and "ritualization" is a more helpful model than “orality/literacy” for understanding textual activity in ancient Israel's environment, "in which rites, texts, and their dynamic social contexts were bound and inseparable." 98

Levtow does not think that the observations made within the orality/literacy analytical framework need to be discarded; rather, biblical scholars should beware of that framework's "tendency to generate misleading dichotomies concerning cultural continuity and change, which in turn support conceptions of static societies and objectified tradition as well as cultural biases toward either end of the oral/written spectrum." $" 99$

Chronicles appears to be a prime example of scribal production both reflecting and shaping social memory. Chronicles is also tied very closely to rituality/liturgy through its emphasis on confession and the Jerusalem temple cult. The next section considers several attempts to discern "textual identities" in Chronicles.

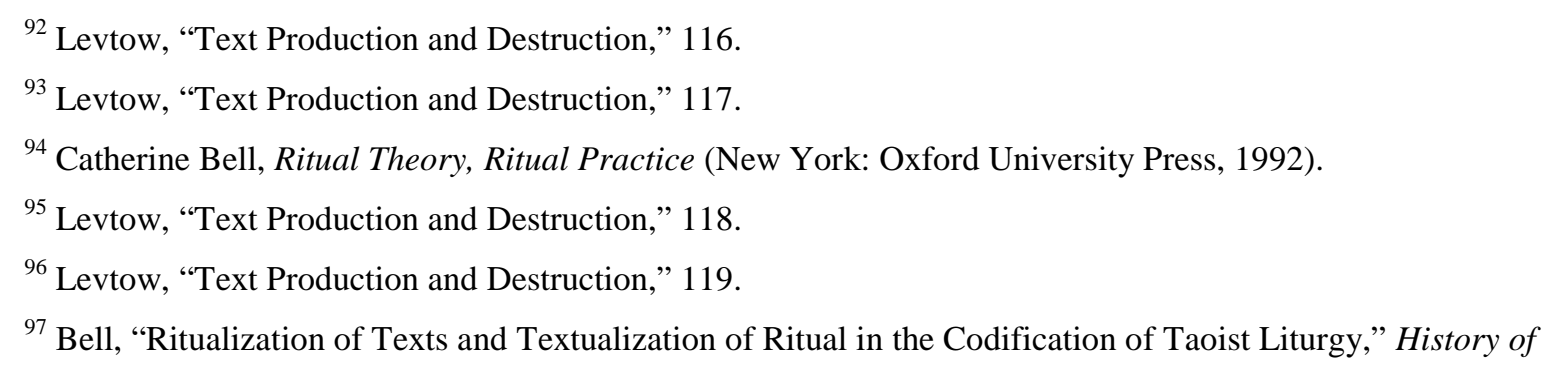
Religions 27 (1988): 368.

\footnotetext{
${ }^{98}$ Levtow, "Text Production and Destruction," 120.

${ }^{99}$ Levtow, "Text Production and Destruction," 137.
} 
In two recent essays, ${ }^{100}$ Jonker attempts to formulate from the book of Chronicles some impressions of the self-understanding of the inhabitants of Yehud.

In "Who Constitutes Society? Yehud's Self-understanding in the Late Persian Era as Reflected in the Books of Chronicles," Jonker outlines his approach to the reconstruction of the self-understanding of Judahites in the Persian period. He begins with the idea that "a close relationship between literature and self-understanding could be envisaged.... The notion of 'textual identities' (which is often used in social constructionism) provides us with a theoretical underpinning for this presupposition." ${ }^{101}$ He offers three insights that follow from this idea. Following Berquist and others, Jonker observes that "the notion 'textual identities' emphasizes the fluid, dynamic, and discursive nature of processes of identity formation." Second, the notion of textual identities "emphasizes the close interrelationship between the social environment within which a group exists, the textual resources that are available in the given culture, and the role that renewed textual construction plays in the process of identity formation." Finally, this notion "cautions us not only to take into account multiple motivational factors that could have contributed to the self-categorization of the Yehudite community in the late Persian period but also to view those motivational factors within a discursive framework."102

In the second part of this essay, Jonker focuses on a particular literary feature of Chronicles that lends itself to this sort of evaluation: direct-speech passages which are presented in the Chronicler's Sondergut. ${ }^{103}$ Jonker also addresses briefly those direct-speech passages from the DtrH that Chronicles omits. Jonker finds that Chronicles gives Judahites and their kings in particular a greater voice, especially when interacting with YHWH. Finally, Jonker integrates these textual observations into a portrait of the Chronicler's view of Israel. Though Chronicles focuses on the southern kingdom of Judah/Yehud, northerners are considered part of the religious community if they follow YHWH through the Jerusalem cult. ${ }^{104}$ Through the direct speech of priestly and royal characters, Jonker postulates that the Chronicler intended the political and priestly authority to

${ }^{100}$ Louis C. Jonker, "Who Constitutes Society? Yehud's Self-understanding in the Late Persian Era as Reflected in the Books of Chronicles," JBL 127 (2008): 703-724; Jonker, "Textual Identities in the Books of Chronicles: The Case of Jehoram's History," in Community Identity in Judean Historiography: Biblical and Comparative Perspectives (ed. Gary N. Knoppers and Kenneth A Ristau; Winona Lake, IN: Eisenbrauns, 2009), 197217.

\footnotetext{
101 Jonker, "Who Constitutes Society?" 703-704.

102 Jonker, "Who Constitutes Society?" 704.

103 Jonker, "Who Constitutes Society?” 707-714.

${ }^{104}$ Jonker, "Who Constitutes Society?” 715-716.
} 
remain distinct in his day. ${ }^{105}$ Finally, Chronicles gives a voice to foreign kings as positive participants in YHWH's plan, over-against Kings' strictly negative portrayal. ${ }^{106}$

Jonker concludes with the reminder that textual identities must not be confused with the "flesh-and-blood" reality of the context. While we can never know the historical situation with complete certainty, such studies are capable providing a window into the self-identity of at least one group within Late Persian Yehud.

In “Textual Identities in the Books of Chronicles: The Case of Jehoram's History,” Jonker posits another "test case": 2 Chronicles 21:2-22:1. ${ }^{107}$ He proposes that in this narrative "we see a Jerusalemite temple community in the process of negotiating a new identity." ${ }^{108}$ First, boundaries between "right Israel" and "wrong Israel" are no longer geographic, ethnic or political, but religious. Second, the foreign nations at the periphery of Judah are "different and foreign but are still under Yahweh's dominion."109 This narrative reflects Yehud's desire to assimilate into Persian provincial existence, but to remain distinct as a people — the perennial dilemma of minority peoples. ${ }^{110}$

Willi considers how the Chronicler's ideological portrait of "all Israel" in the genealogies is intended both to reflect and to reshape the communal memory of the Chronicler's society. ${ }^{111}$ Willi views Chronicles as interpretation of the DtrH in response to changes in the social situation in the later Persian period. ${ }^{112}$ The Chronicler's genealogies are a redefinition of a more inclusive, twelvetribe "all Israel" for a new point in Yehud's history. Willi argues, for example, that the naturalization of Caleb the Kenizzite (Num 32:12; Josh 14:6-14) into the citizenry of Judah indicates "the Chronicler's inclusive view of Judah." 113 Caleb is "made" a son of Hezron (2:18 contra 2:9) because the actual Hezronites settled in Gilead, whereas Caleb, a foreigner by birth,

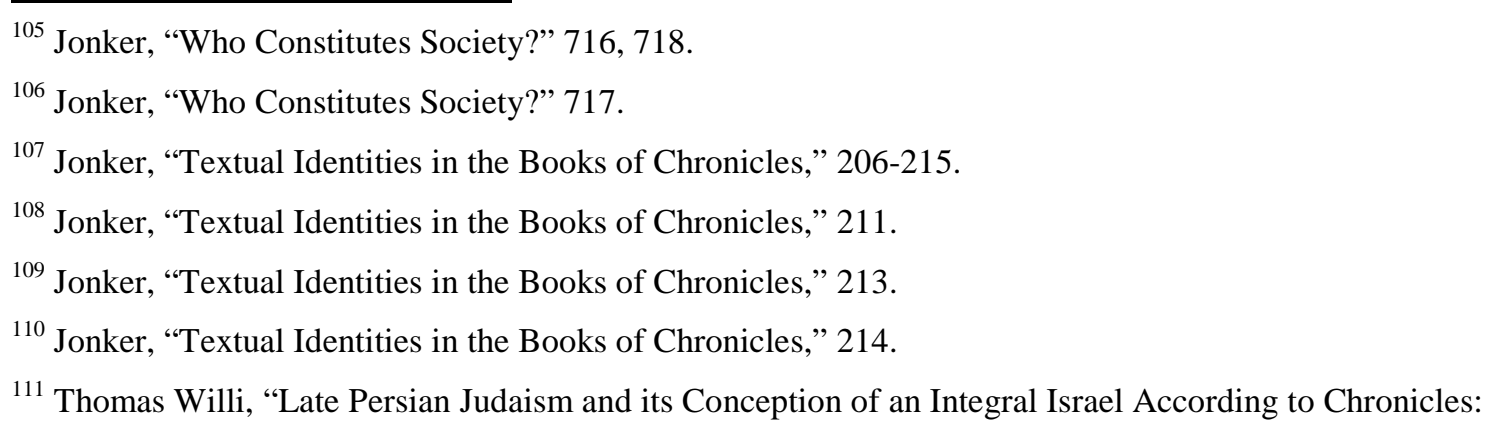
Some Observations on Form and Function of the Genealogy of Judah in 1 Chronicles 2.3-4.23," in Second Temple Studies 2. Temple Community in the Persian Period (ed. Tamara C. Eskenazi and Kent H. Richards; Sheffield: Sheffield Academic, 1994), 147.

112 This is in keeping with his view of Chronicles as exegesis of scripture; cf.Willi, Die Chronik als Auslegung: Undersuchungen zur literarischen Gestaltung der historischen Überlieferung Israels (FRLANT, 106; Göttingen: Vandenhoeck \& Ruprecht, 1972).

${ }^{113}$ Willi, “Late Persian Judaism and its Conception of an Integral Israel,” 159. 
filled the "settlement-vacuum" in Bethlehem and favored Judah. ${ }^{114}$ The Chronicler thus grounds 'all Israel' in scripture and attempts through the text to set forth—in Willi's estimation-a broad vision of Israel's identity in a late Persian context.

The conclusions of Jonker and Willi appear to be in accord with the mainstream scholarly view with which Berquist takes issue, i.e., that during the Neo-Babylonian and Persian periods Jewish identity shifted from a national-ethnic basis to a primarily religious basis. ${ }^{115}$ But Jonker and Willi merely claim that this religious model of Yehudite identity was the Chronicler's view-there were certainly competing models of Yehudite identity, as well as competing Yahwistic cults based the religious model of identity (claiming their own version of Yahwism as the exclusive, true cult).

Ben Zvi's reading of the secession narrative (2 Chr 10:1-11:17) demonstrates the complexity of the Chronicler's conception of community identity. ${ }^{116}$ This narrative appears to consider the sin of the Northern Kingdom to be not secession per se but rather worship outside Jerusalem. ${ }^{117}$ The northerners who assimilate into Judah lose their distinct identity and "remain peripheral to the main history of Israel, whose main focus in Chronicles is and remains Jerusalem/Zion/temple, and by extension Judah (and later Yehud, by implication)." ${ }^{118}$ Yet 2 Chronicles 28:9-15, Ben Zvi argues, allows for pious Israelite behavior outside of Yehud apart from the temple and Davidide monarch, while emphasizing the necessity of a true prophet in such instance to "ideologically Jerusalemize them."119

Furthermore, Chronicles' portrayal of the land as desolate and the book's conclusion with the Cyrus edict marginalizes those who chose not to return from their (temporally limited) exile when they had the chance- "marginalizing them through total exclusion from the implied narrative of reconstruction." ${ }^{120}$ Chronicles is therefore able to create a narrative for its time in which the reconstruction and regathering of true Israel—that is, Jerusalemized Israel—is part of YHWH's

${ }^{114}$ Willi, "Late Persian Judaism and its Conception of an Integral Israel," 158.

${ }^{115}$ Berquist, "Constructions of Identity," 558.

${ }^{116}$ Ehud Ben Zvi, History, Literature and Theology in the Book of Chronicles (Oakville, Conn.: Equinox, 2006), 195-209.

117 "Since the northerners are Israel and since this fact carries within the discourse of Yehud certain expectations regarding behavior and belief, Chronicles suggests that only if the northerners lived within a polity that did not require them to contradict the basic tenets of the Jerusalemite ideology/theology, including but certainly not restricted to matters of temple ritual, then they may remain in their own towns. If this is not the case, just as during the time of the secession...pious Israelites must move to Yehud and fortify it" (Ben Zvi, History, Literature and Theology, 197-198).

\footnotetext{
${ }^{118}$ Ben Zvi, History, Literature and Theology, 199.

${ }^{119}$ Ben Zvi, History, Literature and Theology, 199-200.

${ }^{120}$ Ben Zvi, History, Literature and Theology, 202.
} 
future, yet still allows for true "Israelites" to be faithful in the Diaspora through observance of Jerusalemized traditions and pilgrimages to the temple. ${ }^{121}$

These examples demonstrate the complexity of Yehudite identity in this period and the plurality of textual identities embedded within the Chronicler's work. In the direct-speech passages of the Chronicler's Sondergut and in the secession narrative, Jonker discerns textual voices that point to a religious conception of identity, to which political and ethnic identities are subordinate. Willi discerns a broadening conception of social identity in the genealogies that relates to ethnicity but also transcends it. Ben Zvi addresses the complex relationship between a religious definition of identity and the national/geographical and ethnic notions of identity (the question of how/whether to be a Jew/Judean/“Jerusalemite” outside of Jerusalem).

The complexity of these and other textual witnesses to social identities underscores the importance of the focus on identity formation rather than static identity, as advocated by Berquist. When considering identities in Chronicles, the goal is to move from observations concerning the static, the individual, the factual—-toward conclusions presented in such terms as complexities, trajectories, movements and formations.

\subsubsection{Summary}

This section has explored some of the difficulties inherent both in historical reconstructions of social identity and in understanding the relationship between a text and its community. Three cautionary points are worth restating before moving on to consider tools from political theory that may aid the reconstruction of the Chronicler's social context.

First, social identity is highly fluid and malleable. It is therefore more accurate to speak of a process of identity formation rather than "identity" as a static notion. Any reconstruction of social identity would need to interpolate the trajectory of formation from punctiliar, static historical and textual data. Second, identity is multidimensional. Group- and self-categorizations overlap, and an individual or group may navigate identity across multiple domains, contexts or dimensions. Finally, the text and community have a dynamic, reciprocal relationship with one another. A text is a product of its contexts but also exerts an influence on those contexts.

We have examined some cautious attempts toward understanding the nature of society and social identity from texts. The next section will consider how tentative results from an examination of textual identities might be applied in the reconstruction of the sociopolitical context of Yehud.

${ }^{121}$ Ben Zvi, History, Literature and Theology, 203-204. 


\subsection{POLITICAL THEORIES: SELECTORATE THEORY AND HERESTHETICS}

The present study attempts to situate Chronicles as a piece of rhetoric designed to achieve certain political and religious goals within a social context. In the ancient world, religious ideals had political implications, and vice-versa. It is apparent that the Chronicler's re-presentation of Israel's history reflects interlocking political and religious purposes. It is also evident that the Chronicler's political and religious vision competed with other visions of Judahite identity, polity and worship during this era. ${ }^{122}$

Theories of competitive political decision-making may therefore be useful in explaining the Chronicler's purposes and methods as a strategic actor within a complex sociopolitical system. The following section will suggest that two concepts from the field of political game theory may help to situate the Chronicler's aims and explain aspects of his strategy vis-à-vis intertribal relations. Selectorate theory is a way of modeling the balance of power in a given political system comprised of many individuals with varying interests and degrees of influence. Heresthetic is a strategic attempt to change that balance of power by restructuring the institutional constraints.

\subsubsection{Selectorate Theory}

One of the inherent difficulties of political theory is making valid comparisons of vastly disparate political systems (monarchy, republic, democracy, dictatorship, parliamentarianism, etc.) within many different historical contexts (democracy in ancient Greece vs. modern democracy). Selectorate theory attempts to place these political systems on a spectrum of quantifiable attributes. This spectrum offers significant heuristic value, since unique political actors and institutional constraints can be compared across time and culture.

Selectorate theory seeks to explain the different methods of allocating resources based on a politician's desire to gain and retain power and the institutional context in which the politician operates. ${ }^{123}$ According to this theory, every polity has an institutional space composed of four subsets of individuals. The first subset is quite small: the single leader or group leadership of the polity. The second subset is larger by definition: the selectorate, which is "the group that has a formal role in expressing a preference over the selection of the leadership that rules them, though

${ }^{122}$ For example, rival cultic centers; see Yairah Amit, “Araunah's Threshing Floor: A Lesson in Shaping Historical Memory," in What Was Authoritative for Chronicles? (ed. Ehud Ben Zvi and Diana Edelman; Winona Lake, IN: Eisenbrauns, 2011), 141-42. These competing cultic centers will be examined in further detail (\$7.2).

${ }^{123}$ Bruce Bueno de Mesquita et al., The Logic of Political Survival (Cambridge, MA: MIT Press, 2005 [2003]). 
their expression of preference may or may not directly influence the outcome."124 The third subset is the winning coalition, which is "the group whose support is essential if a leader is to remain in power" (not necessarily a simple "democratic" majority). ${ }^{125}$ The winning coalition is a subset of the selectorate. Finally, every polity includes a constituency that is outside the selectorate and is said to be "disenfranchised." 126

In order to maintain power, the leadership must maintain support of the winning coalition. The leader or leaders have two sorts of benefits they may provide in order to garner support: effective "public goods" that benefit the polity generally, and "private goods" given to the winning coalition. ${ }^{127}$ A change in the leadership occurs when a challenger is able to "convince a sufficient number ${ }^{128}$ of members of the current winning coalition to defect to him," generally by credibly promising more rewards (through some combination of public and private goods) than the current leadership. ${ }^{129}$ A change in leadership is occasionally effected by institutional transition. Institutional transition occurs when the size or composition of the selectorate changes. A skillful leader might, by expanding the size of the selectorate but maintaining the size of the winning coalition, produce a fiercely loyal winning coalition, since its members know that they can easily be replaced by other selectorate members. ${ }^{130}$ Conversely, a skillful challenger might seek to incorporate new selectorate

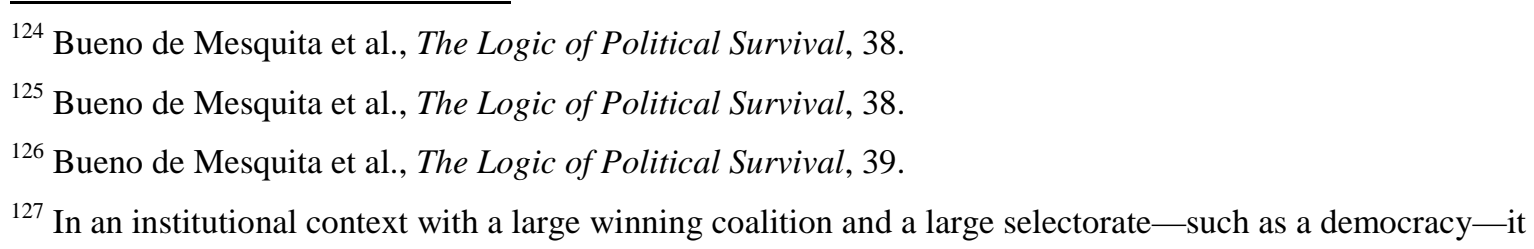
becomes less efficient for a leader to provide private goods and more effective to reward his winning coalition with public goods (generally understood as a more just outcome). In an institutional context in which a leader need only please a small winning coalition in order to retain power-such as a dictatorship, a military junta, or an absolute monarchy - it becomes more efficient for him to reward the winning coalition with private goods (Bueno de Mesquita et al., The Logic of Political Survival, 58-59).

${ }^{128}$ It is important to note that a winning coalition need not be a "democratic" majority of the selectoraterather, the crucial factor is the cumulative influence of the winning coalition members. Consider, for example, a military junta in which one general controls forty percent of the troops, and four other generals control fifteen percent each. Two generals could form a winning coalition against the three, provided that the strong general is one of the two (who would control fifty-five percent of the troops compared to forty-five percent among the three), and granted that military might is decisive in that context.

${ }^{129}$ Bueno de Mesquita et al., The Logic of Political Survival, 59.

${ }^{130}$ One example is the result of the Russian Revolution in 1917, which shifted the institutional arrangement from a small selectorate (the aristocracy) and a small winning coalition (essentially a majority of the aristocracy), to a large selectorate (the entire Soviet population) and a small winning coalition (the Communist Party, by rule approximately ten percent of the Soviet population). Bueno de Mesquita et al. argue that as a result of this shift the Soviet leadership was significantly more secure in its position than the deposed Czar had been (The Logic of Political Survival, 53-55). 
members who might become loyal to him. The crucial point is that changing the size and composition of the selectorate is closely related to social and institutional transition.

Political power in Persian Yehud appears to have been distributed among different entities across several dimensions. Jonker highlights "four levels of socio-political and socio-religious existence" during this period: the Persian imperial context, the regional provincial context, the inner-Yehudite context, and the cultic context. ${ }^{131}$ In each of these dimensions, groups and individuals competed for power and influence. Collective identity was complex and multidimensional.

For example, on the imperial and regional dimensions, Yehud was defined partly by its nearness to the geographic corridors of power that extended the reach of the Persian Empire. ${ }^{132}$ On the inner-Yehudite dimension, cultic centers served not only as "religious" authorities but also as collection centers for royal tax revenue $\left(\right.$ Ezr 4:13, 20), ${ }^{133}$ distributional centers for charity for the poor (cf. Deut 14:28-29; 26:12-13), and as purveyors of "private goods."134 Though the elites of Yehud had some influence over the imperial choice for regional administrator, ${ }^{135}$ the "market" in cultic centers was slightly less constrained: there were other choices. ${ }^{136}$ Finally, different sects vied for influence within the Jerusalem cult itself. ${ }^{137}$

In at least three of these dimensions (regional provincial context, inner-Yehudite context, and Jerusalem cultic context), the wealthier inhabitants of Yehud constituted a selectorate that could form a winning coalition whose support the leadership (or various sectarian aspirants to leadership) needed in order to achieve power.

${ }^{131}$ Jonker, "Engaging with Different Contexts," 63-93.

132 Though the coastal regions such as Syro-Phoenicia were wealthier and more crucial to imperial control of Egypt and Asia (Jonker, "Engaging with Different Contexts," 69-70).

${ }^{133}$ Melody D. Knowles, Centrality Practiced: Jerusalem in the Religious Practice of Yehud \& the Diaspora in the Persian Period (Atlanta: SBL, 2006), 117-118.

${ }^{134}$ Certain portions were allotted to the priests and Levites (Lev 3:3-5, 16); abuse of this privilege for personal gain was widespread as evidenced by its condemnation by the prophets (cf. 1 Sam 2:12-17; Ezek 22:25, 34:2-3; Mic $3: 1-3,11)$.

${ }^{135}$ Grabbe, History of the Jews and Judaism Vol. 1, 154. Sheshbazzar (c. 530s BCE; Ezr 5:14), Zerubbabel (c. 520 BCE; Hag 1:1, 14; 2:2, 21) and Nehemiah (c. 445-432 BCE; Neh 2:9) appear to have held this office at the pleasure of the king, under the authority of the governor of the Ebir-nari satrapy (Grabbe, History of the Jews and Judaism Vol. 1, 148; cf. Jonker, "Engaging with Different Contexts," 69).

${ }^{136}$ Amit, “Araunah's Threshing Floor," 141-142.

${ }^{137}$ Jonker, "Engaging with Different Contexts," 71-74. 


\subsubsection{Heresthetic}

Selectorate theory is linked to the notion of heresthetic (aipsiv, "to choose"), a term coined by political game theorist William Riker. ${ }^{138}$ Heresthetic strategy is concerned with restructuring the process of collective decision-making so as to ensure a certain outcome.

Heresthetic takes several different forms. One form of this strategy involves restructuring issues so as to create previously untenable alliances between portions of the selectorate. ${ }^{139} \mathrm{~A}$ second application involves controlling the order in which options are considered when three or more options are in view. ${ }^{140} \mathrm{~A}$ third and perhaps most difficult form of heresthetic seeks to enfranchise or disenfranchise portions of a selectorate so as to create or dismantle a winning coalition. ${ }^{141}$

Heresthetic strategy may be contrasted with a strategy that is purely "rhetorical." Rhetoric attempts to persuade; heresthetic utilizes rhetoric, but additionally—more significantly_ restructures the game. In this way, a successful heresthetic maneuver can bring about an outcome previously thought unpopular or untenable. Many successful modern herestheticians—such as Lincoln, Churchill, Reagan, and Yeltsin—had views that would have been considered outside the mainstream of the selectorates in their institutional contexts. Most experienced at least one significant political defeat. But they were able to emerge from the political "wilderness" by creatively grouping issues in ways that their political opponents could not. ${ }^{142}$ Heresthetic may explain why certain leaders or ideas succeed despite their apparent lack of broad appeal.

${ }^{138}$ William H. Riker, The Art of Political Manipulation (New Haven: Yale University Press, 1986). See also Iain McLean, "William H. Riker and the Invention of Heresthetic(s)," British Journal of Political Science 32 (2002): 535-558; Kenneth A. Shepsle, “Losers in Politics (And How They Sometimes Become Winners): William Riker’s Heresthetic," Perspectives on Politics 1 (2003): 307-315; Norman Schofield, "Constitutions, Voting and Democracy: A Review," Social Choice and Welfare 18 (2001): 571-600. Shepsle and McLean (539-542) provide helpful explanations of Riker's work, and McLean (545-557) lays out the primary lines of criticism of Riker's ideas in the relevant literature. Schofield (587-595) traces some developments in the discipline resulting from Riker's ideas.

${ }^{139}$ Riker suggests that Lincoln's heresthetic maneuver in the 1858 debates with Stephen Douglas successfully linked the ideas of "free-soil" and "commercial expansion" in such a way that united Lincoln's own fragmented WhigRepublican coalition but fragmented Douglas's Democratic party (The Art of Political Manipulation, 5-6).

${ }^{140}$ See, for example, Riker's account of Pliny the Younger's attempt to achieve a certain vote in the Roman Senate with a plurality but not a majority (The Art of Political Manipulation, 78-88).

${ }^{141}$ A striking example from modern history is Boris Yeltsin's successful plan to co-opt Mikhail Gorbachev's leadership of the Soviet Union by appealing to Russian popular sentiment in the creation of a Russian Communist Party to rival the Soviet Communist Party. By essentially creating a new political institution alongside the previous one, Yeltsin created a selectorate that he could lead, eventually outstripping Gorbachev. See Kiron Skinner et al., The Strategy of Campaigning: Lessons from Ronald Reagan and Boris Yeltsin (Ann Arbor, MI: University of Michigan Press, 2007), 205-248.

${ }^{142}$ Skinner et al., The Strategy of Campaigning, 2-3. 
These two theories are based on the fundamental premise that political actors behave consonant with their perceived self-interest. Yet it should be noted that a leader's perceived selfinterest need not by definition be contrary to the interests of society as a whole.

\subsubsection{Political Context of Persian Yehud}

While the tools of political game theory are difficult to apply to an ancient society with precision, the logic and basic intuition of the theory may be useful in modeling the interactions between actors in complex social situations. Certainly the Chronicler's society consisted of provincial leadership, elite classes with varying degrees of influence, and disenfranchised members of society. Elites competed for influence in the overlapping political and religious spheres.

These observations are not particularly controversial in studies of this period. The notions of selectorate and heresthetic may provide one way of explaining the Chronicler's apparently inclusive ideology. The Chronicler operated within overlapping institutional frameworks. The Chronicler was part of the community of literati that operated in and around the temple. ${ }^{143}$ The temple cult was sanctioned by the imperial government (cf. Ezr 1:1-4; 6:1-12) and supported by tithes paid by the gentry of the province (Neh $12: 44 ; 13: 12)$. The temple community needed to maintain the support of both the regional imperial hierarchy from above and the people of the land from the bottom up. Knowles notes, "In a situation where most members of the population of Yehud were subsistence farmers living in small unwalled villages, these individual offerings were probably small, so the temple would need the support of a large number of people." ${ }^{144}$ There is no evidence suggesting that the temple owned land through which it could support its cultic activities. ${ }^{145}$ It is reasonable to suggest that the Chronicler sought to expand the temple's constituency, and thus its revenue and relative prominence.

We may charitably presume that the Chronicler's broader goal was the success of his people. He believed that this would be achieved through the aid of Israel's God, whose favor must be sought through the proper cult. Thus, he sought to establish the proper cult through promulgation and acceptance of his own views among the religious and political decision-makers.

The Chronicler employs something like a heresthetic strategy in presenting his message. In bypassing conflicting ideologies and focusing on a more "popularly resonant" outlook, the

${ }^{143}$ Ben Zvi, “On Social Memory,” 95-96.

${ }^{144}$ Knowles, Centrality Practiced, 117.

${ }^{145}$ John W. Wright, “'Those Doing the Work for the Service in the House of the Lord': 1 Chronicles 23:624:31 and the Socio-Historical Context for the Temple of Yahweh in Jerusalem in the Late Persian/Early Hellenistic Period," in Judah and the Judeans in the Fourth Century B.C.E. (ed. Oded Lipschits, Gary N. Knoppers and Rainer Albertz; Winona Lake, IN: Eisenbrauns, 2007), 366. For the contrary view, see Joseph Blenkinsopp, "Did the Second Jerusalemite Temple Possess Land?” Transeuphratène 21 (2001): 61-68. 
Chronicler sought to propagate a more inclusive message and aimed for "a more expeditious acceptance of his own work than the written Torah itself had achieved only after an extended period of gestation." ${ }^{146}$ Glatt-Gilad suggests that Chronicles' recommendation of three symbols-temple, David, Torah—was not intended to serve a particular segment of society, but "to promote consensus around the institutions, principles and holy writ that formed the defining elements of overall group identity in his time." 147 The Chronicler re-presents these three symbols, emphasizing their success in the monarchic period by smoothing over problems in the stories of David and Solomon, and underscores the significant penitential component. The Chronicler's approach is thus distinguished from two other theoretical models: an anthology that incorporates and integrates diverse strands (e.g., the Pentateuch), and a halfway point of compromise between competing interests (e.g., the American Constitution). ${ }^{148}$

Knoppers suggests that the Chronicler uses something like a heresthetic strategy to unite the Levitical and priestly factions in the cultic sphere. ${ }^{149}$ Scholarly opinion has been divided on the question of whether the Chronicler's vision of cultic responsibility is pro-Levitical (and therefore Deuteronomic) or pro-Priestly; furthermore, those who see both strands in Chronicles are divided as to which strand represents the later redaction. ${ }^{150}$ Knoppers shows this to be a false dichotomy by demonstrating, for example, the influence of both $\mathrm{P}$ and Deuteronomy on 1 Chronicles 23:28-32, ${ }^{151}$ as well as the use of primarily P terminology to describe extensive Levitical duties. Rather than taking a side, the Chronicler strengthens his own mediating position by appealing to both Pentateuchal traditions. Knoppers concludes:

${ }^{146}$ David A. Glatt-Gilad, "Chronicles as Consensus Literature," in What Was Authoritative for Chronicles? (ed. Ehud Ben Zvi and Diana Edelman; Winona Lake, IN: Eisenbrauns, 2011), 70.

${ }^{147}$ Glatt-Gilad, "Chronicles as Consensus Literature," 75.

${ }^{148}$ Glatt-Gilad, "Chronicles as Consensus Literature," 69.

${ }^{149}$ Gary N. Knoppers, "Hierodules, Priests, or Janitors? The Levites in Chronicles and the History of the Israelite Priesthood," JBL 118 (1999): 49-72. See also Jonker's discussion of the broader context of 1 Chr 23-27 that builds on Knoppers' work: “David's Officials According to the Chronicler (1 Chronicles 23-27): A Reflection of Second Temple Self-Categorization?" in Historiography and Identity (Re)formulation in Second Temple Historiographical Literature (ed. Louis C. Jonker; New York: T\&T Clark, 2010), 65-91.

${ }^{150}$ Knoppers, "Hierodules, Priests, or Janitors," 49-55.

${ }^{151}$ Knoppers suggests that $1 \mathrm{Chr} 23: 28-32$ is not unique in this regard: "The emphasis on the complementary responsibilities of Levites and priests is not unique to this text. Other texts in Chronicles also present a collateral understanding of the relationship between priests and Levites. Moreover, there are parallels, as we have seen, between the duties described here and the duties of the Levites elsewhere in Chronicles" ("Hierodules, Priests, or Janitors," 7172). 
Rather than constituting evidence for a pro-Priestly author or redactor of Chronicles, the summary of levitical duties is evidence for the Chronicler's own distinctive stance, a via media between the positions of Deuteronomy, the Priestly source, and Ezekiel....His configuration of sacerdotal relationships engages and transcends traditional conflicts between rival priestly houses. ${ }^{152}$

Jonker highlights one possible instance of a heresthetic strategy in Chronicles directed toward the tribe of Benjamin. In the narrative of David's census, the Chronicler adapts an aetiological story of Jerusalem's status (2 Sam 24) into a story legitimating Jerusalem/Jebus as the proper cultic site (1 Chr 21:1-22:1). ${ }^{153}$ Jonker notes that in the Chronicler's version of the story, Benjamin and Levi are unharmed by David's poor decision-a decision which the Chronicler presents ultimately as a blessing, since it establishes David as the prototypical penitent sinner and Jerusalem as the temple site. ${ }^{154}$ Jonker argues:

Since Jerusalem is the common denominator between the tribes of Levi and Benjamin, with the first cultically related to Jerusalem and the latter geographically, one may assume that this addition to the narrative was the Chronicler's way of keeping Jerusalem on the high moral ground. In this strategy Benjamin is thus closely related to Jerusalem. ${ }^{155}$

Yet by linking Benjamin "historically" to the Jerusalem cult, the Chronicler also cleverly excludes Benjaminite traditional cultic sites, such as Bethel and Gibeon:

By claiming that this exact site is the place where the sanctuary should be built, the Chronicler establishes neutral terrain for the temple site.... Jebus now becomes the Chronicler's trump card to play over against any Benjaminite claim to authority. ${ }^{156}$

By linking Israel's symbolic past with present issues on multiple dimensions (intra-group categorization within Yehud, Yehudite identity in relation to its regional neighbors), the Chronicler hoped to maintain Jerusalemite exclusivity while also garnering desperately-needed Benjaminite (material) support.

\footnotetext{
${ }^{152}$ Knoppers, "Hierodules, Priests, or Janitors," 71.

153 Amit, “Araunah's Threshing Floor,” 136.

${ }^{154}$ Jonker, "Engaging with Different Contexts," 78-82. See also Jonker, “Of Jebus, Jerusalem and Benjamin:
} The Chronicler's Sondergut in 1 Chronicles 21 Against the Background of the Late Persian Era in Yehud," in Chronicling the Chronicler: The Book of Chronicles and Early Second Temple Historiography (ed. Tyler F. Williams and Paul S. Evans; Winona Lake, IN: Eisenbrauns, 2013), 81-102.

${ }^{155}$ Jonker, "Engaging with Different Contexts," 79.

${ }^{156}$ Jonker, "Engaging with Different Contexts," 79-80. 
Common religious identity as a means to social cohesion plays a significant role in the Chronicler's goals. Religion provides a "symbolic universe" through which the individual as a member of the group understands his own knowledge and experience. ${ }^{157}$ The institutional order is defined and perpetuated through the means of certain discourses, stories, symbols and relationships that are commonly understood and provide meaning to the participants. These discourses, stories and symbols shape the cognitive processes of the participants, influencing what sorts of propositions, stories, symbols and actions are perceived as plausible, acceptable, right, etc. ${ }^{158}$

Any attempt to influence or reshape Judean community identity would need to occur within the constraints of the existing religious discourses, stories and symbols of the society. New discourses, stories and symbols would need to be introduced carefully in order to have a chance of being successful rhetorically. The Chronicler consciously chose to adapt old stories and discourses for his purposes. By working within the preexisting symbolic and discursive worlds reflected in the earlier literature of his people, the Chronicler hoped for the broadest acceptance of his own work.

\subsection{SUMMARY}

This chapter has explored the tools that will be put to use in the next steps of the investigation, as well as the challenges and limitations of those tools.

The following chapters will address the nature and background of the book of Chronicles, and the tribe of Benjamin in history and literature. The intersection between the fundamental disciplines of historical and literary criticism will be on full display in these sections, as we examine literary witnesses to alleged historical events-historiographical literature as historical datum.

As we consider the setting of the book of Chronicles and the portrait of Benjamin in literature, the notion of textual identities will be a critical tool in understanding the perspectives of the biblical authors. Given the perspectives from which these texts are written, what can be known about Benjamin as a distinct but fluid and complex identity?

The third section of this chapter suggested that two related concepts from the field of political theory could explain the Chronicler's context and purpose(s). The notions of selectorate and heresthetic would be a component of the "explanatory" and "representative" phases of the historiographical project, logically following the historical evaluation of the Chronicler's context and the literary examination of Chronicles itself. As postulated above, these concepts may offer some heuristic value for an assessment and description of the Chronicler's goals and strategy as a political actor in a complex, multidimensional social environment.

\footnotetext{
${ }^{157}$ Berger and Luckmann, Social Construction of Reality, 92-93.

${ }^{158}$ Berger and Luckmann, Social Construction of Reality, 93-94.
} 


\section{Chapter 3: Chronicles and the Persian Era}

The purpose of this chapter is to explore key questions and issues in the domain of Chronicles studies that serve as the context for the hypothesized rhetorical strategy of Chronicles that is the essence of this study. This study is not a commentary on Chronicles, nor is it a chronicle of the many issues that have emerged as Chronicles studies have blossomed in the last half-century. Rather, this chapter will focus on key questions of the text, authorship, genres, and socio-historical context(s) of Chronicles-as well as the degree to which various different answers to each of these questions could affect the thesis of the study.

\subsection{CHRONICLES: THE RECEIVED TEXT}

\subsubsection{Title}

"Like many other works from the ancient Near East, the book known to us as Chronicles was originally untitled and anonymously authored." The LXX title of the book, $\tau \omega v$ $\pi \alpha \rho \alpha \lambda \varepsilon 1 \pi \circ \mu \varepsilon v \omega v$, is simply translated, "[book] of the things left out," indicative of the early view of the book's primary purpose as a supplement to Samuel-Kings. The title of the book in the MT is דברי הימים , "the book of the matters of the days," though the antiquity of this title is uncertain. ${ }^{2}$ Knoppers suggests that the mention in 1 Esdras 1:33 of "the book of the histories concerning the kings of Judah" may be an early reference to the book of Chronicles, but this is not certain. ${ }^{3}$

These three names assigned to the book of Chronicles are representative of various opinions concerning the nature and purpose of Chronicles throughout its interpretive history. The title, "things left out," gives the impression that Chronicles is merely a record of things not recorded in Samuel-Kings. ${ }^{4}$ While Chronicles does include material not found in Samuel-Kings, it also includes much near-verbatim repetition of material found in Samuel-Kings, as well as adaptation of SamuelKings material with significant modification. The title, "book of the histories concerning the kings of Judah," draws attention to the book's primary focus on the Southern Kingdom of Judah, but still does not seem to do justice to the extent of the scope and content of Chronicles. A rather opaque

\footnotetext{
${ }^{1}$ Gary N. Knoppers, 1 Chronicles 1-9 (Anchor Bible Commentary; New York: Doubleday, 2004), 47.

${ }^{2}$ Knoppers, 1 Chronicles 1-9, 47.

${ }^{3}$ Knoppers, 1 Chronicles 1-9, 47-48.

${ }^{4}$ Steven S. Tuell, First and Second Chronicles (Interpretation Series; Louisville: John Knox, 2001), 1.
} 
title, "the book of the matters of the days"/"the book of chronicles," offers its audience a chance to consider the book as a unique, self-standing, purposeful work of literature. ${ }^{5}$

\subsubsection{Textual History ${ }^{6}$}

Knoppers provides a helpful survey of the textual witnesses to Chronicles. ${ }^{7}$ Textual criticism of Chronicles - and of the Hebrew Bible generally-is complicated by the relative lateness of the MT (tenth-eleventh century CE) and the widely-varying earlier witnesses to translations into Greek, Latin, Syriac, etc. Text-critical study of Chronicles is complicated further by the fact that the Chronicler's Vorlage differed significantly from the MT versions of Samuel and Kings, particularly Samuel. ${ }^{8}$

Perhaps the most important ancient witnesses to Chronicles are the Greek texts, ${ }^{9}$ the oldest of which dates to the second century BCE. ${ }^{10}$ Knoppers explains two fundamental approaches to the use of the Greek witnesses. One approach, represented by Kahle and followed by many commentators, views the Greek versions as providing "variant readings that illumine enigmatic or problematic Hebrew words and phrases," as well as disclosing "the history of interpretation of

${ }^{5}$ Tuell notes that, according to the Mishnah, Chronicles was to be read by the high priest on the night before Yom Kippur in order to keep him awake- "showing that the rabbis considered Chronicles not only important reading, but stimulating as well!" (First and Second Chronicles, 1)

${ }^{6}$ The books of 1 and 2 Chronicles were originally considered a single work in their Hebrew form. The Masoretic indication of the book's halfway point (חצי הספר בפסוקים) is found in 1 Chr 27:25. The reason for the division was almost certainly the length of the book relative to the usable size of a scroll; the division may have first been made in the Greek versions of the book. The Greek writing system, unlike the Hebrew script, included a full vowel system, as well as some expansion in words. Even after the invention of the codex, which could accommodate longer texts, the division had become so influential that it was maintained and introduced into Hebrew versions of the text in the fifteenth century CE (Knoppers, 1 Chronicles 1-9, 51).

Thus, the division into 1 Chronicles and 2 Chronicles reflects no significant editorial or compositional division. Scholars are nearly unanimous in considering Chronicles as an editorial unity in its final form; one does not speak of a unique message or theology of 1 Chronicles in contrast to a unique message of 2 Chronicles (as one might speak of the unique structure and purposes of the various books of the Pentateuch, for example). The quite sensible dividing point of Chronicles into two books - the succession of David by Solomon - should have no bearing on the determination of the compositional and editorial divisions of the single book of Chronicles.

${ }^{7}$ Knoppers, 1 Chronicles 1-9, 52-65.

${ }^{8}$ Ralph W. Klein, 1 Chronicles: A Commentary (Hermeneia series; Minneapolis: Fortress Press, 2006 ), 26.

${ }^{9}$ Sara Japhet, I \& II Chronicles: A Commentary (Old Testament Library Series; Louisville: Westminster John Knox Press, 1993), 30.

${ }^{10}$ Leslie C. Allen, The Greek Chronicles: The Relation of the Septuagint of I and II Chronicles to the Massoretic Text (2 vols.; VTSup 25, 27; Leiden: Brill, 1974), I.23. 
biblical books." ${ }^{11}$ Lagarde championed an alternative approach that views the Greek versions and other translations as 1) representing various stages in evolving Hebrew texts, and 2) versions that are themselves evolving to parallel development of the Hebrew texts. ${ }^{12}$ The discovery of other books of the Hebrew Bible at Qumran has proven the validity of Lagarde's basic approach.

Unfortunately, Qumran provides little aid to the reconstruction of the text of Chronicles by way of direct witness: only two fragments (4Q118 or 4QChr) containing a portion of 2 Chronicles 28:27-29:3 have thus far been discovered. ${ }^{13}$ Nevertheless, Knoppers notes, the Qumran discoveries have significantly aided the field of text criticism; observations about the relationships between Qumran, Greek, and Masoretic versions of other books of the Hebrew Bible guide our understanding of these versions' contributions to the reconstruction of the text of Chronicles. ${ }^{14}$ Witnesses to the books of Samuel and Kings have been found at Qumran, and the Samuel witnesses in particular point to a complicated textual history of these books. ${ }^{15}$

An in-depth discussion of the relationships between the textual sources of Chronicles is beyond the scope of the present study. Knoppers refuses to take an approach that "centralizes the MT," preferring an eclectic approach that regards the MT as "the best witness for reconstructing the Chronicler's original text." ${ }^{16}$ Klein likewise argues that "standard text-critical principles" must be applied, which includes the use of Greek versions, Qumran, Josephus, and other witnesses. ${ }^{17}$ The dependence of the Targums, Vulgate, and other translated versions of Chronicles on earlier texts such as the OG and the MT means that their value is more interpretive than text-critical.

The present study will work primarily from the MT of Chronicles as the oldest extant Hebrew witness, but will consider other witnesses to Chronicles and witnesses to other synoptic passages in biblical books where necessary. Since one of the goals is to discover ideological and rhetorical differences between the Chronicler and his sources, eclectic textual criticism will be important in establishing the extent and nature of those differences. For example, the Qumran and Greek versions of Samuel appear to be based on an Old Palestinian text type, and these versions agree in numerous instances with the MT version of 1 Chronicles 10-21 against MT Samuel. ${ }^{18}$ Differences between MT Samuel and MT Chronicles thus cannot always be ascribed to the Tendenz

${ }^{11}$ Knoppers, 1 Chronicles 1-9, 53.

${ }^{12}$ Knoppers, 1 Chronicles 1-9, 53-54.

${ }^{13}$ Knoppers, 1 Chronicles 1-9, 54; Klein, 1 Chronicles, 26.

${ }^{14}$ Knoppers, 1 Chronicles 1-9, 54-55.

${ }^{15}$ See the helpful discussion in Klein, 1 Chronicles, 28-30.

${ }^{16}$ Knoppers, 1 Chronicles 1-9, 64-65.

${ }^{17}$ Klein, 1 Chronicles, 26.

${ }^{18}$ Lemke counts nearly a hundred instances in which the LXX of Samuel agrees with 1 Chr 10-21 against MT Samuel; see Werner E. Lemke, “The Synoptic Problem in the Chronicler’s History,” HTR 58 (1965): 362. 
of the Chronicler. McKenzie argues that the text of Kings used by the Chronicler was protorabbinic in character, and therefore differences between MT Kings and MT Chronicles are more likely to reflect the Chronicler's own perspective. ${ }^{19}$

\subsubsection{Date}

\subsubsection{Factors}

The factors that complicate the question of the date(s) and authorship of Chronicles are many and varied. Because the work claims no authors or date, there are only internal clues to be compared with external data.

The first complicating factor is that of the book's unity. It is certainly possible that Chronicles is a composite work developed by several authors/editors over a period of time. Thus, internal evidence that appears to establish a range of dates may only apply to the particular section of Chronicles in which it is found.

Additionally, some historical details found in Chronicles, most notably geographical details (place names, borders, regions), may have been updated long after the book was substantially complete. For example, in a recent essay Finkelstein argues from archaeological evidence that the geographical locations mentioned in 1 Chronicles 2-9-which, he assumes, are indicative of the author's time - could not reflect the Iron II (eighth or seventh centuries BCE) or Persian-era realities, but rather reflect the situation of the late Hellenistic (Hasmonean) period. ${ }^{20}$ Whether or not Finkelstein's conclusions come into wider acceptance, this evidence would have definite bearing not on the date of the substance of the entire book of Chronicles, but only on the date of the extant form of the genealogical section (1 Chr 1-9), which could itself have been composed earlier and edited later.

Another complicating factor is Chronicles' use of scripture and the use of Chronicles itself as scripture. The terminus ad quem for Chronicles depends upon the earliest possible dating of its sources. ${ }^{21}$ Conversely, if other literary works that may themselves be more definitively dated make

${ }^{19}$ Steven L. McKenzie, The Chronicler's Use of the Deuteronomistic History (HSM 33; Atlanta: Scholars Press, 1985), 119, 155.

${ }^{20}$ Israel Finkelstein, “The Historical Reality Behind the Genealogical Lists in 1 Chronicles,” JBL 131 (2012): 65-83.

${ }^{21}$ Klein, 1 Chronicles, 16. 
use of Chronicles by allusion or citation, then these would establish a terminus ante quem for Chronicles. $^{22}$

Finally, attempts to date Chronicles based on its themes and ideological/theological concerns are inherently imprecise. All that can be established on these grounds are possibilities and perhaps probabilities. Knoppers writes:

\begin{abstract}
...Attempts to situate Chronicles within a specific historical context are commendable, but their presumption of a direct correlation between a text and a given context needs to be rethought. Authors can respond to or even react against their circumstances. To be sure, a literary work may betray its historical milieu in spite of itself. There may be hints—anachronisms, references, citations - that are important for dating. Nevertheless, the literary products need not exactly mirror the conditionswhether dreary or ebullient-in which their authors lived. Writers are not only shaped by their circumstances, they can also seek to shape those circumstances. One should allow some latitude in dating a literary work, recognizing the complex relationships between authors and the social conditions in which they live. ${ }^{23}$
\end{abstract}

\title{
3.1.3.2 How Early and How Late?
}

Knoppers considers a sixth-century date for Chronicles to be unlikely, given the lack of attention to the "specifications and construction of Solomon's sanctuary," which would have been relevant during the construction of the second temple: "[The Chronicler] substantially abbreviates...the Deuteronomistic narration of Temple building and Temple furnishings (2 Chr 3:15:1; cf. $1 \mathrm{Kgs} 6: 1-7: 51)$. This suggests that the Temple was already standing when the author wrote." 24

Peltonen notes that a significant period of time must have elapsed between the minting of a Persian coin (daric) mentioned in connection with David (1 Chr 29:7) and the composition of Chronicles for such an anachronism to have been tolerated. ${ }^{25}$

Knoppers remarks that the main aspects of the Chronicler's agenda might be appropriately situated at any number of times between the mid-sixth and mid-third centuries (Knoppers' suggested terminus ad quem and terminus ante quem for Chronicles). "The Jerusalem sanctuary was not without rivals": cultic centers existed at Bethel, Elephantine, and elsewhere. Furthermore, "the Jerusalem Temple was dependent on the goodwill of patrons for its maintenance. Persian

\footnotetext{
${ }^{22}$ Knoppers, 1 Chronicles 1-9, 106; Kai Peltonen, “A Jigsaw Without A Model? The Date of Chronicles," in
} Did Moses Speak Attic? Jewish Historiography and Scripture in the Hellenistic Period (ed. Lester L. Grabbe; JSOTSup 317; Sheffield: Sheffield Academic Press, 2001), 225.

\footnotetext{
${ }^{23}$ Knoppers, 1 Chronicles 1-9, 105.

${ }^{24}$ Knoppers, 1 Chronicles 1-9, 111.

${ }^{25}$ Peltonen, “A Jigsaw Without A Model,” 229-230.
} 
period texts paint an uneven picture of support for the Temple within Yehud."26 The themes of "all Israel," David, and "the perpetual ties between God, people, and land," were points of contention that might have been raised at any number of moments within the Achaemenid period and early Hellenistic period, given the existence of Diaspora communities and fluctuating nationalist hopes within Yehud. ${ }^{27}$ These considerations suggest that caution is in order when situating a particular theme or strand — such as tribal relations between Benjamin and Judah—in a specific period within this larger era.

For example, Glatt-Gilad argues that the Chronicler used the Pentateuch as "a paradigm for communal consensus," and that the early fourth century would have been the most likely time for the Chronicler to apply this model in his composition. ${ }^{28}$ However, a date of c. $400 \mathrm{BCE}$ for the promulgation of the Pentateuch is by no means certain or precise. Also, the Chronicler could in theory have chosen any time to model his work after the Pentateuch's consensus model; one could argue that a lengthier gap between the Pentateuch and Chronicles would have allowed for strengthened authority of the Pentateuch and therefore increased incentive for the Chronicler to model his work after it.

\subsubsection{Hellenistic Influence?}

Numerous parallels between Chronicles and certain forms of Hellenistic literature have been suggested. ${ }^{29}$ Hoglund notes at least three features of the Chronicler's historiography that have Hellenistic parallels: genealogies, "wise counselor" type-scenes, and authentication by appeals to sources and large numbers. ${ }^{30}$ Edelman and Mitchell suggest that Chronicles may be modeled after varieties of local Greek histories. ${ }^{31}$ Other scholars, such as Klein ${ }^{32}$ and Barstad, ${ }^{33}$ have been more cautious about such comparisons.

${ }^{26}$ Knoppers, 1 Chronicles 1-9, 112.

${ }^{27}$ Knoppers, 1 Chronicles 1-9, 113.

${ }^{28}$ David A. Glatt-Gilad, "Chronicles as Consensus Literature," in What Was Authoritative for Chronicles? (ed. Ehud Ben Zvi and Diana Edelman; Winona Lake, IN: Eisenbrauns, 2011), 74.

${ }^{29}$ Welten has suggested that various military and building projects mentioned in Chronicles relate to a thirdcentury situation; see Peltonen, “A Jigsaw Without A Model,” 230, 240.

${ }^{30}$ Kenneth G. Hoglund, "The Chronicler as Historian: A Comparativist Perspective," in The Chronicler as Historian (ed. M. Patrick Graham et al; Sheffield: Sheffield Academic Press, 1997), 19-29.

${ }^{31}$ Diana Edelman and Lynette Mitchell, "Chronicles and Local Greek Histories," in What Was Authoritative for Chronicles? (ed. Ehud Ben Zvi and Diana Edelman; Winona Lake, IN: Eisenbrauns, 2011), 229-252.

${ }^{32}$ Responding directly to Hoglund's essay, Klein writes: "Every historian, without doubt, is indebted to the cultural influences of his or her day, and the Chronicler's method of writing history reflects consciously and unconsciously literary and cultural conventions of the time, but I do not find the parallels with Greek histories distinctive enough to conclude that the Chronicler was actually acquainted with any of these histories. Comparative 
Two points of clarification are necessary in this regard. First, apparent parallels with Hellenistic literature, to the extent that they do exist in Chronicles, are not definitive proof of Hellenistic influence on the Chronicler. Second, Hellenistic influence on the Chronicler's method or purpose would not then require a date for Chronicles after Alexander's conquest of Yehud (332 BCE) ${ }^{34}$ Many of the Greek historiographical works that may have parallels in Chronicles are dated to the fifth, sixth or even seventh centuries. ${ }^{35}$ It is certainly plausible that Hellenistic literary and historiographical techniques were known in the Levant long before Alexander:

There certainly would have been opportunity for the biblical writers and literate Jewish elite to gain familiarity with Greek writing trends in the Persian and Hellenistic periods-a time when there was direct interchange of ideas within the eastern Mediterranean basin, and access to Greek manuscripts by literate, educated Jews was almost certainly possible. ${ }^{36}$

Hellenistic parallels to Chronicles are intriguing, but should be used very cautiously in attempts to date the book precisely to a particular half-century. ${ }^{37}$

\subsubsection{Summary}

The date (or dates) of Chronicles is dependent upon a variety of factors, including the dating of the book's sources and its literary unity—both of which will be considered later in this chapter. The concluding verses of the received version of Chronicles may be an attempt to connect the past era with the author-editor's own era, indicating a pre-Alexander date. Given the uncertainties surrounding comparisons to Hellenistic literature, and the median of current scholarly opinion, a mid-fourth-century date for Chronicles seems most likely.

study of Greek and Hebrew historiography is still at an early stage but has already yielded some results" (1 Chronicles, $18)$.

${ }^{33}$ Hans M. Barstad, "Deuteronomists, Persians, Greeks, and the Dating of the Israelite Tradition," in Did Moses Speak Attic? Jewish Historiography and Scripture in the Hellenistic Period (ed. Lester L. Grabbe; JSOTSup 317; Sheffield: Sheffield Academic Press, 2001), 47-77. Barstad openly doubts whether it is possible to say with any certainty whether a text belongs in the Persian era or Hellenistic era (76).

${ }^{34}$ Knoppers, 1 Chronicles 1-9, 102-104; idem., "Greek Historiography and the Chronicler's History: A Reexamination,” JBL 2003 (122): 627-650.

${ }^{35}$ Edelman and Mitchell, "Chronicles and Local Greek Histories,” 229-230.

${ }^{36}$ Edelman and Mitchell, "Chronicles and Local Greek Histories,” 246.

${ }^{37}$ Some scholars argue for redactional activity throughout the Persian and Hellenistic periods but for a Maccabean-era date: Georg Steins, Die Chronik als kanonisches Abschlußphänomen: Studien zur Enstehung und Theologie von 1/2 Chronik (BBB 93; Weinheim: Beltz Athenäum, 1995), 419-439; Ernst M. Dörrfuß, Mose in den Chronikbüchern: Garant theokratischer Zukunftserwartung (BZAW 219; Berlin: Walter de Gruyter, 1994), $282-283$. 


\subsubsection{Relationship to Ezra-Nehemiah}

Klein provides a helpful survey of the development of the understanding of Chronicles' relationship to the book of Ezra-Nehemiah. ${ }^{38}$ Nineteenth- and early twentieth-century studies of Chronicles generally held that these two books were of common authorship. ${ }^{39}$ However, an influential study published in 1968 by Japhet questioned this view based on linguistic dissimilarities. ${ }^{40}$ Since then, the consensus has shifted toward the separate-authorship view on linguistic and ideological grounds, though a minority still holds to some sort of common authorship/editorship. ${ }^{41}$

There are four main pieces of evidence for single authorship of Chronicles-EzraNehemiah. ${ }^{42}$ First, linguistic connections between the two books have been suggested. Japhet's article brought these connections into question; subsequent studies by Talshir ${ }^{43}$ and Polzin ${ }^{44}$ have reaffirmed the earlier view, while Williamson ${ }^{45}$ and Throntveit ${ }^{46}$ have argued with Japhet against common authorship. Second, the overlap between 2 Chronicles 36:22-23 and Ezra 1:1-3a "implies that the story told in 1 and 2 Chronicles is continued in Ezra-Nehemiah." ${ }^{47}$ However, this could merely be an attempt by a later author to connect his work to the work of an earlier author. ${ }^{48}$ Third, since the book of 1 Esdras incorporates material from all three books (2 Chr 35-36; Ezr 1-10; Neh 8:1-13a), it has been suggested that the book "represents a fragment of the translation of Chronicles-Ezra-Nehemiah before the Nehemiah Memoir had been added to it," ${ }^{49}$ though Klein does not find this evidence convincing. Fourth, the books share certain themes, such as a focus on

${ }^{38}$ Klein, 1 Chronicles, 2-10.

${ }^{39}$ Klein, 1 Chronicles, 2-3.

${ }^{40}$ Sara Japhet, "The Supposed Common Authorship of Chronicles and Ezra-Nehemiah Investigated Anew," VT 18(1968): 330-371.

${ }^{41}$ Notably Joseph Blenkinsopp, Ezra-Nehemiah: A Commentary (OTL; Philadelphia: Westminster Press, 1988), 47-54.

42 Steven L. McKenzie, 1-2 Chronicles (Nashville: Abingdon Press, 2004), 21-22.

${ }^{43}$ David Talshir, "A Reinvestigation of the Linguistic Relationship Between Chronicles and Ezra-Nehemiah," VT 38(1988): 165-193.

${ }^{44}$ Robert Polzin, Late Biblical Hebrew: Toward an Historical Typology of Biblical Hebrew Prose (HSM 12; Missoula, Mont.: Scholars Press, 1976).

${ }^{45}$ H.G.M. Williamson, Israel in the Books of Chronicles (Cambridge: Cambridge University Press, 1977).

${ }^{46}$ Mark A. Throntveit, "Linguistic Analysis and the Question of Authorship in Chronicles, Ezra, and Nehemiah,"VT 32(1982): 201-216.

${ }^{47}$ Klein, 1 Chronicles 1-9, 6.

${ }^{48}$ Klein, 1 Chronicles, 6.

${ }^{49}$ Klein, 1 Chronicles, 7. 
the Jerusalem cult, the holy land, and penitence for $\sin { }^{50}$ But the books also exhibit significant ideological and thematic differences, particularly pertaining to intermarriage, the exodus event, the inclusion of the Northern Kingdom, and the Davidic monarchy. ${ }^{51}$

Klein notes that even scholars who argue for common authorship, such as Willi and Welten, are in agreement that "Chronicles is to be interpreted as a literary work in its own right and not part of a longer work consisting of Chronicles-Ezra-Nehemiah." 52 This will be the approach taken in this study. The book of Ezra-Nehemiah provides valuable evidence concerning the relationship between the golah and she'erit communities earlier in the Persian period. ${ }^{53}$

\subsubsection{Place in the Canon}

The Christian canon, following the arrangement of the LXX, places Chronicles with the "historical books," between Samuel-Kings, whose story overlaps with that Chronicles, and before Ezra, which is linked chronologically to Chronicles by the Cyrus decree (2 Chr 36:22-23; Ezr 1:14). In the Hebrew canon, Chronicles belongs with the ketuvim, rather than with the nevi'im as do Samuel and Kings. While the most important medieval texts place Chronicles at the beginning of the ketuvim before the Psalter, ${ }^{54}$ most versions follow the rabbinic tradition of placing Chronicles at the end of the ketuvim, and therefore at the end of the Hebrew Bible. ${ }^{55}$ Chronicles in its Hebrew canonical context "was regarded as the last book of Scripture-an appropriate placement for a work that attempts to distill and summarize the entire history of God's dealings with God's people." 56

The canonical position of Chronicles may have implications for the present study. The fact that Chronicles was chosen to conclude the Hebrew Bible indicates its significance beyond simply being a final summary of Israel's story-books that were written later (such as Daniel) and books pertaining to later eras (such as Esther and Ezra-Nehemiah) nevertheless precede Chronicles. Though many books of the ketuvim deal with life under Gentile rule, Chronicles provides the "final word" to Jewish communities exiled and presently living under pagan empires.

\footnotetext{
${ }^{50}$ Klein, 1 Chronicles, 8.

${ }^{51}$ Klein, 1 Chronicles, 8-10; see also Japhet, I \& II Chronicles, 4-5.

${ }^{52}$ Klein, 1 Chronicles, 6.

${ }^{53}$ Jonathan E. Dyck, The Theocratic Ideology of the Chronicler (Biblical Interpretation Series 33; Leiden:
} Brill, 1999); Yigal Levin, “Who Was the Chronicler's Audience? A Hint from His Genealogies,” JBL 122 (2003): $237-$ 242.

\footnotetext{
${ }^{54}$ Notably the Aleppo (c. 900 CE) and Leningrad (c. 1008 CE) Codices (Knoppers, 1 Chronicles 1-9, 76).

${ }^{55}$ Tuell, First and Second Chronicles, 3.

${ }^{56}$ Tuell, First and Second Chronicles, 3.
} 


\subsection{COMPOSITION: SOURCES AND REDACTION}

The following section will address significant issues pertaining to the composition of Chronicles as literature, particularly the relationship between the sources and the received text(s).

\subsubsection{Synoptic Parallels and Apparent Sources}

McKenzie observes, "The topic of the Chronicler as redactor truly lies at the heart of Chronicles studies and continues to preoccupy nearly every treatment of this literature, so that merely noting his main interests barely scratches the surface. ${ }^{, 57}$ Chronicles in its received form is an edited work apparently comprised of four categories of source materials.

First, much of the source material for Chronicles is represented in the received forms of other books of the Hebrew Bible. The canonical synoptic material for 1 Chronicles 10-29 and 2 Chronicles includes: 1 Samuel 31; 2 Samuel; 1-2 Kings; Isaiah 36-39; Ezra 1:1-3a; and numerous psalms. ${ }^{58}$

Second, some of the Chronicler's material parallels other passages of the Hebrew Bibleparallels that could not be categorized as direct citation/adaptation. The genealogies/lists of 1 Chronicles 1-9 have parallels in Genesis, Exodus, Numbers 26, Joshua, Judges, Ruth, 1-2 Samuel, 1-2 Kings, and Nehemiah $11 .^{59}$ However, much of the Chronicler's parallel material is not expounded or elaborated in these extant sources, leading to the suggestion that the Chronicler used or adapted other oral or written tradition within this section. ${ }^{60}$

Third, the Chronicler mentions other sources which are not preserved within the Hebrew canon:

- "The chronicles/matters of Samuel the seer, the chronicles of Nathan the prophet, and the chronicles of Gad the seer" (1 Chr 29:29)

- "The chronicles/matters of Nathan the prophet, the prophecy of Ahijah the Shilonite, and the visions of Iddo the seer concerning Jeroboam the son of Nebat" (2 Chr 9:29)

${ }^{57}$ Steven L. McKenzie, "The Chronicler as Redactor," in The Chronicler as Author: Studies in Text and Texture (ed. M. Patrick Graham and Steven L. McKenzie; JSOTSup 263; Sheffield: Sheffield Academic Press, 1999), 87-88.

${ }^{58}$ For discussion of the issues surrounding the Chronicler's use of psalms, see Howard N. Wallace, "What Chronicles Has to Say About Psalms," in The Chronicler as Author: Studies in Text and Texture (ed. M. Patrick Graham and Steven L. McKenzie; JSOTSup 263; Sheffield: Sheffield Academic Press, 1999), 267-291; Klein, 1 Chronicles, 359-370; James W. Watts Psalm and Story: Inset Hymns in Hebrew Narrative (JSOTSup 139; Sheffield: JSOT Press, 1992), 162-166.

${ }^{59}$ Klein, 1 Chronicles, 38.

${ }^{60}$ Klein, 1 Chronicles, 43. 
- "The chronicles/matters of Shemaiah the prophet and of Iddo the seer" (2 Chr 12:15)

- "The midrash of the prophet Iddo" (2 Chr 13:22)

- "The chronicles/matters of Jehu the son of Hanani, which are recorded in the Book of the Kings of Israel" (2 Chr 20:34)

- "The chronicles/matters of the seers" (2 Chr 33:19)

- "Written in the Laments" (2 Chr 35:25), reflected in the traditional ascription of authorship of the book of Lamentations to Jeremiah

It is difficult effectively to judge the legitimacy of these source claims, which some have suggested may be merely an "authentication device" designed to give "the semblance of inner knowledge on the part of the writer and so lend credibility to the flow of the narrative.",61

Finally, Chronicles no doubt contains material composed by the Chronicler himself, without previous source. Given that we have no access to the Chronicler's alleged non-canonical sources, it is impossible definitively to distinguish between such citations/allusions and compositions of the Chronicler's own hand.

\subsubsection{Source-Critical Concerns}

Peltonen's contribution to the edited work, The Chronicler as Author, provides a helpful starting point for discussion of source-critical approaches to Chronicles. ${ }^{62}$ He distinguishes between two sorts of source criticism: the older, more common attempts to identify The Chronicler's sources and establish what level of historical accuracy should be attributed to Chronicles; and an approach that theorizes about sources in order to establish the Chronicler's intentions within his own context as a historical datum. ${ }^{63}$

Peltonen observes that, despite the importance of the question of Chronicles' relationship to Samuel-Kings, the majority of contemporary literary approaches to Chronicles focus on its "unity and literary integrity," rather than on producing new source- and redaction-critical theories, "particularly of a detailed nature." 64 The Chronicler's work should be evaluated in its own right:

${ }^{61}$ Hoglund, “A Comparativist Perspective," 26-29.

${ }^{62}$ Kai Peltonen, "Function, Explanation and Literary Phenomena: Aspects of Source Criticism as Theory and Method in the History of Chronicles Research," in The Chronicler as Author: Studies in Text and Texture (ed. M. Patrick Graham and Steven L. McKenzie; JSOTSup 263; Sheffield: Sheffield Academic Press, 1999), 18-69.

${ }^{63}$ Peltonen, "Function, Explanation and Literary Phenomena," 20.

${ }^{64}$ Peltonen, "Function, Explanation and Literary Phenomena," 67. See also McKenzie's essay in the same volume, providing further details of certain redaction-critical theories ("The Chronicler as Redactor," 71-80). 
Whatever materials he may have had at his disposal, his work is not to be considered a mere compilation of earlier materials, but a deliberate composition of a skillful author who created from earlier tradition a new theological and historiographical synthesis for his own time. ${ }^{65}$

Explanations of certain details within Chronicles based on a source-critical theory must be considered individually and carefully, "with due recognition of the fact that conclusions are mostly tentative and beyond unambiguous methodological control." 66

Peltonen also observes that the spectrum of scholarly opinion tends more toward the opinion that the Chronicler utilized some actual extra-biblical sources, rather than toward the notion that all such claims in Chronicles are false - though the mere citation of a source does not ensure historical veracity. ${ }^{67}$ The quest to reconstruct the Chronicler's sources has yielded little valuable result. ${ }^{68}$

\subsubsection{Samuel-Kings and Chronicles: A Common Source?}

There exists a broad consensus within Chronicles scholarship that the books of 2 Samuel and 1-2 Kings—in some pre-Masoretic form—served as sources for the Chronicler. ${ }^{69}$ This consensus has recently been challenged by several scholars, including Auld, ${ }^{70} \mathrm{Ho}^{71}$ and Person. ${ }^{72}$

${ }^{65}$ Peltonen, "Function, Explanation and Literary Phenomena," 67.

${ }^{66}$ Peltonen, "Function, Explanation and Literary Phenomena," 68.

${ }^{67}$ Peltonen, "Function, Explanation and Literary Phenomena," 67-68. For example, Japhet argues that the Chronicler used a variety of extra-biblical sources, including both early materials—reflected most likely in genealogies, census records, or "passages from the monarchial period"- - and late postexilic materials relating to the organization of the Temple personnel. Japhet also contends that the absence of elaboration or clarification in certain passages is evidence of the Chronicler's general adherence to sources. She emphasizes, however, the literary and ideological unity of the Chronicler's composition despite the use of apparently disparate materials of diverse origins (I \& II Chronicles, $19,23)$.

68 "It appears that nowadays we know much less about Chr.'s extra-biblical sources than ever before" (Peltonen, "Function, Explanation and Literary Phenomena," 68).

${ }^{69}$ Japhet, I \& II Chronicles, 16-17; Klein, 1 Chronicles, 30-32; idem., 2 Chronicles, 1-2; Knoppers, 1 Chronicles 1-9, 66-67.

${ }^{70}$ A. Graeme Auld, Kings Without Privilege: David and Moses in the Story of the Bible's Kings (Edinburgh: T\&T Clark, 1994); "What Was the Main Source of the Books of Chronicles?" in The Chronicler as Author: Studies in Text and Texture (ed. M. Patrick Graham and Steven L. McKenzie; JSOTSup 263; Sheffield: Sheffield Academic Press, 1999), 91-99.

${ }^{71}$ Craig Y.S. Ho, "Conjectures and Refutations: Is 1 Samuel XXXI 1-13 Really the Source of 1 Chronicles X 1-12?”VT 45(1995): 82-106; “The Stories of the Family Troubles of Judah and David: A Study of Their Literary Links,"VT 49(1999): 514-531.

${ }^{72}$ Raymond F. Person, Jr., The Deuteronomic School: History, Social Setting, and Literature (Atlanta: Society of Biblical Literature, 2002); The Deuteronomic History and the Book of Chronicles: Scribal Works in an Oral World (Atlanta: Society of Biblical Literature, 2010); “'Identity (Re)Formation as the Historical Circumstances Required,”” in 
Auld proposed that a "common inherited text" was a source for both Samuel-Kings and Chronicles, which was then "independently supplemented" by each author/tradition. ${ }^{73}$ By arguing that Samuel-Kings is the product of extensive supplementation of a proto-Judah-history, Auld sought to "[open] Samuel-Kings as they stand to...radical literary and historical scrutiny"- similar to the scrutiny Chronicles had received ever since de Wette. ${ }^{74}$ Ho, a student of Auld, proposed two instances in which synoptic problems might be better explained by a common-source model than a DtrH-as-source model. ${ }^{75}$

Person's argument for common source begins with the notion that evidence of textual development of the Hebrew Bible (i.e., from the Vorlage of the LXX and the versions found at Qumran, toward the MT) indicates continued redactional activity on the Deuteronomic books well into the Persian period. ${ }^{76}$ This continued scribal activity, he argues, is the work of a Deuteronomic school that continued to revise and supplement both the book of Deuteronomy and the so-called Deuteronomistic books (Joshua, Judges, Samuel, Kings). For this reason, Person rejects the distinction between "Deuteronomic" and "Deuteronomistic," which originated in a reductionist view of unidirectional influence of proto-Deuteronomy on a later Deuteronomistic History. ${ }^{77}$

If significant redactional work on the DtrH continued into the Persian period, ${ }^{78}$ then, Person reasons, the work of the Deuteronom(ist)ic community and the community that produced Chronicles might have been "competing contemporary historiographies."79 The common source for these historiographies was "an early redaction of the Deuteronomic History that was undertaken in the Babylonian exile, something toward which the text-critical evidence of Samuel-Kings points

Historiography and Identity (Re)formulation in Second Temple Historiographical Literature (ed. Louis C. Jonker; New York: T\&T Clark, 2010), 113-121.

73 Auld, Kings Without Privilege, 4.

${ }^{74}$ Auld, Kings Without Privilege, 4.

${ }^{75}$ Ho argues that the differences between the two accounts of Saul's death are more difficult to explain by the Chronicler's adaptation of 1 Sam 31 than by the author of Samuel's adaptation of a common source that is unaltered in Chronicles ("Conjectures and Refutations"). In the context of a comparison of the narratives of Gen 38 and 2 Sam 11 20, Ho argues that it makes more sense for the author of 2 Sam 7:12 to have altered his source-which is preserved without modification in $1 \mathrm{Chr}$ 17:11--than for the Chronicler to have altered 2 Sam 7:12 ("The Stories of the Family Troubles of Judah and David," 527 n18).

${ }^{76}$ Person, The Deuteronomic School, 34-42.

${ }^{77}$ Person, The Deuteronomic School, 4-7.

${ }^{78}$ See, for example, Thomas C. Römer, The So-Called Deuteronomistic History: A Sociological, Historical and Literary Introduction (London: T\&T Clark, 2005), 165-183.

${ }^{79}$ Person, The Deuteronomic History and the Book of Chronicles, 18; "The Deuteronomic History and the Books of Chronicles: Contemporary Competing Historiographies," in Reflection and Refraction: Studies in Biblical Historiography in Honour of A. Graeme Auld (ed. Robert Rezetko et al.; Leiden: Brill, 2007), 315-336. 
us." ${ }^{80}$ This common-source theory would account for the similarities between Chronicles and the $\mathrm{DtrH}$, but also the text-critical differences and material that is unique to each work. Person also challenges the distinction commonly made between Early Biblical Hebrew (traditionally assigned to the DtrH) and Late Biblical Hebrew (the language of Chronicles). ${ }^{81}$

Auld's version of the common-source theory has not come into wide acceptance, as several scholars have demonstrated numerous instances in which the Chronicler presupposes knowledge of passages found in Samuel-Kings that he nevertheless does not include in his work. ${ }^{82}$ Certain aspects of Person's work that integrate new understandings of orality and the development of texts are mostly mainstream.

Since Person acknowledges that some exilic redaction of the DtrH was Chronicles' source, there are three possible explanations for material unique to the DtrH. Everyone acknowledges textcritical explanations in certain instances. A second explanation, preferred in more instances by Person, is a Deuteronom(ist)ic redaction/addition subsequent to the initial composition of Chronicles. A third explanation, supported by scholars such as Knoppers ${ }^{83}$ and Klein ${ }^{84}$ in more instances, would be deliberate exclusion by the Chronicler.

The common-source theory of the composition of Samuel-Kings and Chronicles presents several challenges and possibilities for the present study, which is based on the premise that the Chronicler consciously adapted material from a text very similar to the received form of SamuelKings. How would the hypothesis be affected if Chronicles and Samuel-Kings developed contemporaneously from common source material?

One of the arguments of this study will be that the Chronicler excludes potentially scandalous Benjamin-related material from his Deuteronomistic source. If the common-source theory is correct, such lacunae might not be deliberate exclusion by the Chronicler but rather deliberate inclusion by the Deuteronomist. (Of course, this material could still have been found in a hypothetical source document, and then deliberately included by the Deuteronomist and deliberately excluded by the Chronicler.) Even in these sorts of scenarios, the difference in portrayal of Benjamin and intertribal relations will be important, but the contrast will have different

\footnotetext{
${ }^{80}$ Person, The Deuteronomic History and the Book of Chronicles, 18.

${ }^{81}$ Person, The Deuteronomic History and the Book of Chronicles, 23-40.

${ }^{82}$ McKenzie, “The Chronicler as Redactor,” 70-90; Klein, 1 Chronicles, 31-32; Knoppers, 1 Chronicles 1-9,
} 67.

${ }^{83}$ Knoppers, 1 Chronicles 1-9, 67-68.

${ }^{84}$ Klein, 2 Chronicles, 1-2. Klein also asserts: "My commentary will show numerous places where the Chronicler alludes to or presupposes knowledge of passages in the books of Samuel that he did not include in his own narration of history....The Chronicler used the nearly final form of Samuel-Kings, although from a copy of the text of those books that is often variant from the MT of Samuel and Kings" (1 Chronicles, 31-32). 
implications for historical reconstruction. Perhaps instead of representing "snapshots" of intertribal relations early and late in the Persian period, respectively, the DtrH and Chronicles could represent contemporaneous but divergent impressions of late-Persian/early-Hellenistic intertribal relations.

A reversed argumentation may be possible, as well. If this study can establish that the attitudes toward Benjamin found in Chronicles and the DtrH are radically divergent and characteristic of different eras of Yehudite intertribal relations, it may actually undermine certain sorts of common-source scenarios. This would be quite an ambitious argument that may fall beyond the scope of the present study.

One of the motivations behind the common-source theory is an attempt to explain material that is unique to Samuel-Kings. Those who argue that the DtrH is a source for Chronicles have at least two sorts of explanations for these unique passages: text-critical explanations, ${ }^{85}$ and the Tendenz of the Chronicler. This study hopes to provide ideological and rhetorical explanations for certain sorts of lacunae in Chronicles that can also explain elements of the Chronicler's Sondergut: an irenic attitude and rhetorical strategy toward the tribe of Benjamin.

\subsubsection{Redaction Criticism and Editorial Unity}

Related to the issue of the Chronicler's sources is the question of the compositional unity of the received form of Chronicles. Chronicles contains material compiled from many sources, encompassing many literary genres, including narratives, genealogies, census figures, geographical lists, songs and poems, speeches, and prophecies. Were these materials compiled and edited by a single individual or group on one occasion, or by numerous individuals and groups over time (and over how long a period)?

Certain redactional models considered Chronicles with Ezra-Nehemiah to be a tripartite, unified Chronistic History. The more well-known varieties of this theory are advocated by Freedman and Cross. ${ }^{86}$ As the consensus shifted away from the common-authorship view (see discussion above), these theories fell out of favor. ${ }^{87}$ Other scholars have posited a second, Levitical

85 "To be sure, proponents of the dependence of Chronicles upon the Former Prophets have had difficulty explaining the discrepancies between them in synoptic passages, especially the minuses in Chronicles. Why would the Chronicler randomly, it seems, omit certain words, phrases, or groups of sentences from his Vorlage? In this context, one can readily understand the criticisms leveled by Auld and Ho against modern biblical scholarship. If one grants, however, in the wake of the discoveries at Qumran, that the Chronicler's Vorlagen of certain books (esp. Joshua and Samuel) differed in some important respects from the MT of these books, the criticisms largely fall away" (Knoppers, 1 Chronicles 1-9, 67-68).

${ }^{86}$ D. Noel Freedman, “The Chronicler's Purpose,” CBQ 23(1961): 436-42; Frank M. Cross, “A Reconstruction of the Judean Restoration,” JBL 94 (1975): 11-14.

${ }^{87}$ McKenzie, "The Chronicler as Redactor," 71-78. 
or Priestly redaction of Chronicles, including parts or all of 1 Chronicles 1-9, 15-16, 23-27; and 2 Chronicles $29-31 .{ }^{88}$ Other scholars have posited the existence of even more compositional layers. ${ }^{89}$ Klein writes of his commentary on Chronicles:

\begin{abstract}
I have ascribed very few passages to a second hand....My approach is based in part on the general trend in much current scholarship, particularly in North America, to focus on the final form of the text in a synchronic fashion. It also results from my belief that the reasons given for considering passages secondary are often weak and ambivalent or flow from circular reasoning. ${ }^{90}$
\end{abstract}

Klein compares his approach to those of Williamson, De Vries, Japhet, and Johnstone, who also emphasize the compositional unity of Chronicles with minor caveats. ${ }^{91}$ Klein is critical of approaches that ascribe numerous large chunks of Chronicles to a second hand: "With such radical surgery, one only reconstructs and interprets a document of one's own making, having little to do with the accomplishment of the Chronicler himself." 92 Knoppers finds that the "literary heterogeneity within Chronicles," rather than indicating multiple layers of redactional activity, actually reflects:

...the distinctive features of the Chronicler's compositional technique: his adroitness in drawing upon originally disparate lemmata, his ability to acknowledge and negotiate different ideological perspectives, and his capacity for pursuing his own agenda as he engages a variety of earlier biblical traditions. $^{93}$

In this view, instances of apparent disunity within the Chronicler's presentation are actually expected, given the careful balance between pro-Priestly and pro-Levitical traditions, and between the Priestly and Deuteronomic legal traditions. ${ }^{94}$ Knoppers concludes:

This is, of course, not to say that there are no additions, glosses, or embellishments to the original text of Chronicles. From a text-critical perspective alone, we can be fairly certain there were such

${ }^{88}$ Knoppers, 1 Chronicles 1-9, 91.

${ }^{89}$ Knoppers, 1 Chronicles 1-9, 91-92. Steins posits no fewer than seven compositional layers relating to various Levitical/cultic groups: Die Chronik als kanonisches Abschlußphänomen, 419-439.

${ }^{90}$ Klein, 1 Chronicles, 11.

${ }^{91}$ H.G.M. Williamson, 1 and 2 Chronicles (NCB; Grand Rapids: Eerdmans, 1982), 12-15; Simon J. De Vries, 1 and 2 Chronicles (FOTL; Grand Rapids: Eerdmans, 1989), 13; Japhet, I \& II Chronicles, 7; William Johnstone, 1 and 2 Chronicles (2 vols.; JSOTSup 253; Sheffield: Sheffield Academic Press, 1998), 1.22.

\footnotetext{
92 Klein, 1 Chronicles, $11 \mathrm{n} 93$.

${ }^{93}$ Knoppers, 1 Chronicles 1-9, 92.

${ }^{94}$ Knoppers, 1 Chronicles 1-9, 92-93.
} 
additions. But these interpolations and glosses seem to display the character of random additions rather than of systematic redactions. ${ }^{95}$

\title{
3.2.4 Conclusions
}

Peltonen concludes his essay on the history of source-critical approaches to Chronicles:

\begin{abstract}
After a couple hundred years of critical effort, the basic questions are still open: What were Chr.'s sources? What was their historical nature and value? How did Chr. use them? As long as commonly accepted answers to these questions escape us — and perhaps they always will—source criticism of Chronicles will preserve its peculiar nature as a combination of theory and method with a more or less conspicuous functional role determined and legitimated by varying scholarly interests. ${ }^{96}$
\end{abstract}

Peltonen's astute observation should evoke caution for any study based on synoptic comparisons with Samuel-Kings. Given the central role of synoptic comparison to the present study, it is important at this juncture to make several clarifying statements regarding sources, unity, and authorship.

1) Following the approaches of Klein, Japhet, Williamson, Knoppers, and others described above, this study approaches the final form of Chronicles as a unified composition, produced over a relatively short period of time, with a few later, minor additions.

2) The term "Chronicler" will be used for the sake of convenience to describe the person or persons responsible for the unified composition of Chronicles. The use of the singular term does not preclude the possibility that Chronicles was composed by a group. The term "Chronicler" signifies the final layer of intentionality that brought together disparate sources into a single work. ${ }^{97}$

3) Chronicles appears to be drawing quite deliberately and openly from Samuel-Kings and certain psalms. Given how late Chronicles seems to have been composed/edited, it is certainly possible that nearly all of the parallel material in Chronicles is adapted from other books of the canon. ${ }^{98}$ In nearly all instances, the notion of other books adapting material from Chronicles seems unlikely. The alternative proposals of Auld and Person-which

${ }^{95}$ Knoppers, 1 Chronicles 1-9, 93.

${ }^{96}$ Peltonen, "Function, Explanation and Literary Phenomena," 69.

${ }^{97}$ It is customary to note that masculine pronouns will be used in reference to the "Chronicler" throughout this study merely for convenience - though most scholars agree that female authorship is historically improbable.

98 "By the time the author of Chronicles wrote, much of the literature that we associate with the Hebrew Bible was already written. The Chronicler draws extensively upon these rich literary traditions" (Knoppers, 1 Chronicles 1-9, 66). 
postulate a common source from which Samuel-Kings and Chronicles are both (contemporaneously) derived-do not adequately explain many of the intertextual phenomena observed in these works.

4) Divergences between Chronicles and its apparent sources may result from textual differences between the Chronicler's Vorlage and the Masoretic text.

5) Conversely, parallels between Chronicles and apparent sources may be the result of subsequent textual assimilation or conflation.

6) The Chronicler's appeals to non-biblical sources do not appear to be incredible. The Chronicler no doubt hoped to bolster the credibility of his work by appeals to sources, but that claim does not automatically become illegitimate because not all his sources are available to us. ${ }^{99}$ This is not to say that the Chronicler's sources were themselves reliable. The historical value of each apparent citation/allusion needs to be evaluated individually on its own merits. ${ }^{100}$

\subsection{CHRONICLES: THEOLOGICAL HISTORIOGRAPHY?}

\subsubsection{Chronicles as Historiography?}

The problem of the historical value of Chronicles depends on several subsidiary questions. Was the Chronicler a historian, and if so, in what sense was Chronicles intended as history? What is the historical value of the Chronicler's extant sources, especially Samuel and Kings? What might the historical value of the Chronicler's non-extant sources have been? To what extent is Chronicles useful for historical reconstruction of his own day? Finally, how relevant to the thesis of this study is the historicity of the Chronicler's portrait of preexilic Israel and Judah?

\footnotetext{
${ }^{99}$ Without affirming the historicity of the Chronicler's historical judgments, Peltonen nevertheless states: "For [the Chronicler], history was subservient to theology. That is why he used his sources, whatever they were, freely and creatively in order to meet the historical and religious needs of his day. Therefore, one should not speak of an intentional falsification of history in Chronicles" ("Function, Explanation and Literary Phenomena," 66; emphasis added).

100 "The existence of sources for the Chronicler's non-synoptic sections is thus firmly established, and is not denied even by some of the book's most severe critics (e.g., Wellhausen). It is the nature, origin and reliability of these sources which remain problematic, and these should be investigated in each passage on a case-by-case basis" (Japhet, $I$ \& II Chronicles, 19).
} 
In his contribution to a volume entitled, The Chronicler as Historian, Kalimi considers four views of the Chronicler's purpose and the genre of Chronicles, providing a helpful starting point for consideration of Chronicles as history. ${ }^{101}$

Kalimi describes the "low" view of Chronicles that prevailed in the nineteenth and early twentieth century. ${ }^{102}$ Wellhausen, for example, described Chronicles as "midrash": "Like ivy it overspreads the dead trunk with extraneous life, blending old and new in a strange combination."103 Kalimi finds this view of Chronicles to be quite inadequate and tinged with anti-Semitism.

Kalimi next considers the view posited by Willi ${ }^{104}$ of the Chronicler as primarily an exegete of scripture: "Willi tends to find in Chronicles the application of the rules whereby the Sages interpreted the Pentateuch." 105 While Willi is correct that the Chronicler is interpreting earlier historical works, Kalimi points out that the Chronicler did not treat these "canonical" works as “immutable, sealed books," but rather as "raw materials for manipulation as he saw fit."106 Furthermore, Chronicles' style does not seem explanatory, even in adapting earlier material that would have required explanation. Finally, "Willi's definition of the literary genre of Chronicles as 'commentary' and its purpose as that of interpreting the canonical books negates completely and necessarily the historical value of Chronicles as a source for the pre-exilic period," a move that Kalimi is hesitant to make. ${ }^{107}$

Third, Kalimi considers the view of Chronicles as primarily a theological discourse. While Kalimi acknowledges that the Chronicler's theology played a crucial role in shaping his historiographical discourse, "nevertheless, the main feature of Chr's work is history—not theology_though it is indeed a 'sacred history' and not a 'secular history.' Therefore, Chr is primarily a historian rather than a theologian." 108

Kalimi concludes, of course, by answering in the affirmative the question posed by the essay's title. He points to the following features of Chronicles as evidence:

${ }^{101}$ Isaac Kalimi, "Was the Chronicler a Historian?" in The Chronicler as Historian (ed. M. Patrick Graham, Kenneth G. Hoglund and Steven L. McKenzie; Sheffield: Sheffield Academic Press, 1997), 73-89.

${ }^{102}$ See also M. Patrick Graham, The Utilization of 1 and 2 Chronicles in the Reconstruction of Israelite History in the Nineteenth Century (SBLDS 116; Atlanta: Scholars Press, 1990).

${ }^{103}$ Kalimi, "Was the Chronicler a Historian," 75.

104 Thomas Willi, Die Chronik als Auslegung: Undersuchungen zur literarischen Gestaltung der historischen Überlieferung Israels (FRLANT 106; Göttingen: Vandenhoeck \& Ruprecht, 1972).

\footnotetext{
${ }^{105}$ Kalimi, "Was the Chronicler a Historian," 77.

${ }^{106}$ Kalimi, "Was the Chronicler a Historian," 79.

${ }^{107}$ Kalimi, "Was the Chronicler a Historian," 80-81.

${ }^{108}$ Kalimi, "Was the Chronicler a Historian," 82.
} 
The author deals with the past; he collects material from the earlier books and perhaps additional sources; he selects from the sources, evaluates, and interprets them; he makes connections between the sources; and above all, his work as a whole is imprinted with a unique 'philosophy' of history. ${ }^{109}$

This does not make Chronicles trustworthy as a historical account of the pre-exilic period, but each datum in the book should be considered on its own merits and not merely dismissed out of hand. ${ }^{110}$ Kalimi concludes:

The literary nature of Chronicles is historiography, and Chr is not simply a 'copyist' but a creative artist, a historian who selected his material from earlier books, reorganizing and editing it in the order, context and form he found appropriate. He also made connections between the texts; stylized, reshaped, and explained some of them; and harmonized others. Chr also attempted to express his theology and 'philosophy' of history through his composition and so created a literary work that fits well within late biblical historiography. ${ }^{111}$

Kalimi's conclusion appears to be a fair representation of the mainstream contemporary approaches to the historical value of Chronicles. ${ }^{112}$ Most scholars agree that on some level the Chronicler intended to represent the past. The questions that remain are the veracity of the Chronicler's various historical claims, and the precise nature of the Chronicler's historiographical method. Related to both these questions are concerns about the various literary genres used by the Chronicler.

More recently, Chronicles has been compared to the phenomenon of "rewritten Bible," which is widely attested in second-temple era Jewish literature. ${ }^{113}$ Jewish communities retold and reshaped scriptural material for a wide variety of theological, historical and political purposes.

${ }^{109}$ Kalimi, "Was the Chronicler a Historian," 83.

${ }^{110}$ Kalimi, "Was the Chronicler a Historian," 85.

${ }^{111}$ Kalimi, "Was the Chronicler a Historian," 89.

${ }^{112}$ For example: Japhet, I \& II Chronicles, 43-49; Knoppers, 1 Chronicles 1-9, 133-134; Ehud Ben Zvi, History, Literature and Theology in the Book of Chronicles (Oakville, Conn.: Equinox, 2006), 26-34; Klein, 1 Chronicles, 19.

${ }^{113}$ George J. Brooke, "Rewritten Bible," in Encyclopedia of the Dead Sea Scrolls (Lawrence H. Schiffman and James C. VanderKam, eds.; 2 vols; New York: Oxford University Press, 2000), II.778. See also Knoppers, 1 Chronicles 1-9, 129; Philip S. Alexander, "Retelling the Old Testament," in It Is Written: Scripture Citing Scripture. Essays in Honour of Barnabas Lindars, SSF (ed. D.A. Carson and H.G.M. Williamson; Cambridge: Cambridge University Press, 1988), 100. For an alternative view, see Klein, 2 Chronicles, 4-5. 
These works of rewritten scripture reflect varying degrees of freedom to change the earlier scriptures and/or incorporate new material from other sources. ${ }^{114}$

Certain material found in the Hebrew canon itself, including the book of Chronicles, may anticipate the later "rewritten Bible" phenomenon. Chronicles follows the general sequence of an earlier biblical work, integrating material from a variety of sources, and adding explanatory information. "Rewritten Bible" also tends to have strong theological and didactic tendencies, which Chronicles certainly shares. While the "rewritten Bible" genre may explain some aspects of the Chronicler's work, there are other aspects that are incongruous with such a designation, such as the Chronicler's highly selective adaptation of Pentateuchal materials in the genealogies, and extensive supplementation of David material compared with 2 Samuel. ${ }^{115}$

\subsubsection{Historical Value of Chronicles}

If Chronicles is "historiography" - that is to say, intended as a re-presentation of past events-how should such an undertaking be evaluated from the perspective of the modern critical historian? What historical insight does the Chronicler provide into the era he purports to describe? Three brief points should be raised in this regard.

First, the historical value of Chronicles depends in large measure on the historical value of Samuel-Kings. Certainly these books contain some information that appears to be verifiable by other textual or material evidence; much information that is perhaps compatible with but not verifiable by external evidence; and some information that is apparently incongruous with external evidence.

In regard to the "past" that these books purport to represent, Chronicles—like Samuel and Kings - should be judged by the standards of ancient historiography. Both the Chronicler and the Deuteronomist utilize many historiographical techniques that would not meet modern critical standards. ${ }^{116}$ Hoglund aptly notes:

${ }^{114}$ Knoppers lists the following general characteristics of so-called "rewritten-Bible texts": 1) such a text takes an earlier biblical book or collection as a point of departure; 2) the text selects from, interprets, comments on, and expands portions of that book, "addressing obscurities, contradictions, and other perceived problems"; 3) the text generally emulates the form and sequence of the source text, without citation formulation; 4) the text attempts to provide "a coherent interpretive reading" of the source—comments and interpolations are moral, theological, didactic, clarifying, and expository; and, 5) the text "presupposes some familiarity on the part of the readers with the base text, but untrained readers will not find clear demarcations between the base text and the additions made to it" (Knoppers, 1 Chronicles 1-9, 130).

115 Knoppers, 1 Chronicles 1-9, 132.

${ }^{116}$ See Lester L. Grabbe, "Who Were the First Real Historians? On the Origins of Critical Historiography," in Did Moses Speak Attic? Jewish Historiography and Scripture in the Hellenistic Period (ed. Lester L. Grabbe; JSOTSup 
It should be self-evident that it is both methodologically flawed and the height of modern hubris to assess Chr's work using the criteria and standards of modern, positivistic historiography....Since the narrative, as we have it, treats events and the reigns of kings in a sequence, and since the narrative possesses cohesion both in writing style and in recurring thematic elements, we may begin by calling it a 'history'. How, then, does Chr conceptualize the writing of the narrative? ${ }^{117}$

For example, the Chronicler appears to have composed numerous prophetic and royal speeches for his narratives, ${ }^{118}$ or perhaps interpolated material from other sources into his narratives (such as the use of numerous psalms, including the exilic Ps 106, in the account of David's celebration; cf. 1

Chr 16). Placing speeches in the mouths of ancient figures was an accepted technique of narrative historiography in the ancient world. ${ }^{119}$ Breisach discusses Thucydides' justification of this technique:

Homer and Herodotus had used speeches in their works, but Thucydides had labeled the first an unreliable poet and rejected the type of history the second had produced. How then did he justify the use of speeches which obviously were not accurate records of what was said?

"As for the speeches made on the eve of the war or during the course, it was hard for me, when I heard them myself, and for any others who reported them to me to recollect exactly what had been said. I have therefore put into the mouth of each speaker the views that, in my opinion, they would have been most likely to express, as the particular occasions demanded, while keeping as nearly as I could to the general purport of what was actually said."

He also could have stated that speeches set the stage, described situations, and told about motivations without recourse to long enumerations and the use of abstractions. They read well and sounded even better in recitations. They also came closer to the ideal of truth whenever they contained parts of actual speeches, as in the case of Pericles' so-called Funeral Oration. In other words, the speeches of Thucydides contained what was said, could have been said, or should have been said. Indeed,

317; Sheffield: Sheffield Academic Press, 2001), 156-181. Contra Halpern, Grabbe asserts that the Greeks were the first “critical historians," and argues that later Jewish historians learned such a critical spirit from the Greeks (176-181).

${ }^{117}$ Kenneth G. Hoglund, "The Chronicler as Historian: A Comparativist Perspective" in The Chronicler as Historian (ed. M. Patrick Graham, Kenneth G. Hoglund and Steven L. McKenzie; Sheffield: Sheffield Academic Press, 1997), 21.

${ }^{118}$ Sara Japhet, The Ideology of the Book of Chronicles and its Place in Biblical Thought (trans. Anna Barber; Winona Lake, IN: Eisenbrauns, 2009 [1977]), 7-8; see also the discussion by Mark A. Throntveit, “The Chronicler's Speeches and Historical Representation," in The Chronicler as Historian (ed. M. Patrick Graham et al; Sheffield: Sheffield Academic Press, 1997), 204-224.

${ }^{119}$ Cf. Hoglund, "Chronicler as Historian,” 23-26. 
speeches became so useful a narrative device that historians abandoned their use only a few centuries ago. $^{120}$

The Chronicler, re-presenting the story of David, Solomon and the Kingdom of Judah for a new audience, deems it appropriate to place canonical psalms and composed speeches in the mouths of his characters at key points, perhaps with the similar motivation to that of Thucydides: these speeches/songs were what David (1 Chr 16, 29), Solomon (2 Chr 6), Jehoshaphat (2 Chr 20), etc., should have said.

In this regard, however, the Chronicler's Sondergut provides more historical insight into the Chronicler's own day than into the monarchy. Ultimately, the goal of this study is insight into the setting and message of the Chronicler in his context, rather than the historical value of either Chronicles or the DtrH for reconstructions of the monarchic period. Yet the "real," flesh-and-blood history of Israel was not an irrelevancy for the Chronicler himself. Thus a modern inquiry into the methods and goals of this ancient historian will in certain instances entail inquiry-through the lens of modern critical historiography_into the nature of the events he describes.

\subsubsection{Theological Emphases}

There is universal agreement among commentators-even those who categorize Chronicles as historiography - that the Chronicler's theological outlook pervades his representation of Israel's story. The Chronicler's main theological themes are expounded at length in numerous studies. ${ }^{121}$ This subsection will consider briefly how each of these major themes could relate to a rhetorical strategy directed at Benjamin in the Chronicler's context.

\subsubsection{Monotheism}

"Full" monotheism - the belief that YHWH of Israel is the only true God, and that other deities are not gods at all-is presupposed in Chronicles. ${ }^{122}$ The Chronicler assumes and frequently explains that YHWH is sovereign and orchestrates events, including the actions of kings and foreign nations (e.g., $1 \mathrm{Chr}$ 10:13-14; 2 Chr 11:4; 35:21; 36:22-23).

${ }^{120}$ Ernst Breisach, Historiography: Ancient, Medieval, and Modern (Chicago: University of Chicago Press, 1983), 17 (emphasis added); citation from Thucydides, The Peloponnesian Wars, 1.22.

${ }^{121}$ Japhet, I \& II Chronicles, 43-49; idem., The Ideology of the Book of Chronicles, passim; M. Patrick Graham, Steven L. McKenzie, and Gary N. Knoppers, eds., The Chronicler as Theologian: Essays in Honor of Ralph W. Klein (JSOTSup 371; New York: T\&T Clark, 2003); Ben Zvi, History, Literature and Theology in the Book of Chronicles; Klein, 1 Chronicles, 44-48; Knoppers, 1 Chronicles 1-9, 80.

122 Japhet, The Ideology of the Book of Chronicles, 33. 
The Chronicler's religious exclusivism is nevertheless inclusive, in that all peoplesincluding foreigners and the separated northern tribes-are welcome to worship YHWH in Jerusalem (2 Chr 2:11-12; 6:32-33; 9:1-9; 13:5-12; 30:1-11; 30:18; 31:1; 35:18). This religious motivation of the Chronicler must be considered a component of any message directed toward Benjamin: the Chronicler believes that worshiping YHWH in Jerusalem as prescribed in Law and tradition is the only proper worship for anyone-Judahite, Levite, Benjaminite, Northerner, or foreigner-to perform.

\subsubsection{Reward and Retribution}

The Chronicler's conception of reward and retribution in response to human action is more immediate and individual than conceptions of divine action elsewhere in the Hebrew Bible, particularly Kings. ${ }^{123}$ Japhet argues that the DtrH and Chronicles both explain history through the lens of God's justice, but the two histories begin with different starting points: the destruction of Judah and the temple for the former, and the "overall religious system" for the latter. ${ }^{124}$

This and other differences observed between the two histories may have implications for Benjaminite reception of the Chronicler's message. The Deuteronomist's interest in explaining the destruction and exile led him to include or emphasize contentious moments of Israel's story that would have been less immediately relevant for the Chronicler's message—such as Judges 19-21 and 1 Samuel 8-30. In the Chronicler's worldview, the complexities of Israel's monarchial history are less relevant than the cultic and administrative faithfulness of individual rulers.

\subsubsection{Cult Centralization and Confession}

The Chronicler's focus on the Jerusalem temple and the cultic responsibilities of the priests and non-priestly Levites has been the subject of extensive study. The Chronicler shares the Deuteronom(ist)ic belief that Jerusalem is "the place in which the LORD your God will choose for His name to dwell" (cf Deut 12-16; 26:2), and highlights the kings of Judah who take steps to centralize worship at the Jerusalem temple.

Closely related to the idea of cultic centralization is the Chronicler's theme of confession. The Chronicler's conception of divine retribution for sin is complemented by his doctrine of personal and communal confession of sin-a doctrine expounded most prominently in 2 Chronicles 6. Solomon's prayer, largely adapted from 1 Kings 8, expresses the view that people collectively or any individual-Israelite or foreigner — may be forgiven of sin, provided they turn their hearts toward YHWH and his "house."

\footnotetext{
${ }^{123}$ Klein, 1 Chronicles, 46-47.

${ }^{124}$ Japhet, The Ideology of the Book of Chronicles, 120.
} 
The Chronicler's emphasis on the special roles of the tribes of Levi and Judah in a Jerusalem cult might not have been easily accepted by Benjaminites who likely had closer Yahwistic cultic sites available (at Gibeon, for example). ${ }^{125}$ The Chronicler would need to demonstrate the antiquity of Jerusalem as the proper cultic center, as well as historic Benjaminite connection to Jerusalem.

\subsubsection{Kingship}

Chronicles differs significantly from the DtrH in its presentation of David and the monarchy of Israel/Judah. The DtrH judges kings on their adherence to the Law. Since most of the kings of Israel and Judah fall significantly short of the Deuteronomistic ideal, the DtrH is characterized by a tension between the curses for sin and the Davidic covenant (2 Sam 7). The Chronicler judges kings based on their furtherance of the cultic and administrative organization of Israel; the legitimacy and continuation of the Davidic monarchy are never in question.

Again, the Chronicler's emphasis on Judahite David's special place beside the sons of Levi in YHWH's plan would likely have met with Benjaminite opposition. Whether or not a Benjaminite claimant to the governorship/vassalage of Yehud vied with a Judahite claimant in the Chronicler's day is unclear. ${ }^{126}$ Whether the Chronicler was able to successfully craft a message that balanced a positive, inclusive view of Benjamin with an eternal Judahite monarchy is a central question in this study.

\subsubsection{All Israel}

The theme of "all Israel" in Chronicles is well-established. ${ }^{127}$ As discussed in the introductory chapter, the phrase כל ישראל occurs forty-six times in Chronicles. The Chronicler emphasizes the unity of the tribes of Israel, even those separated politically from Judah/Yehud. ${ }^{128}$

${ }^{125}$ Diana V. Edelman, "Did Saulide-Davidic Rivalry Resurface in Early Persian Yehud?” in The Land That I Will Show You: Essays on the History and Archaeology of the Ancient Near East in Honour of J. Maxwell Miller (ed. J. Andrew Dearman and M. Patrick Graham; Sheffield: Sheffield Academic Press, 2001), 78-81; see also Joseph Blenkinsopp, "Benjamin Traditions Read in the Early Persian Period," in Judah and the Judeans in the Persian Period (ed. Oded Lipschits and Manfred Oeming; Winona Lake, Ind.: Eisenbrauns, 2006), 629-645.

${ }^{126}$ Edelman, "Saulide-Davidic Rivalry," 78-81.

${ }^{127}$ Japhet, The Ideology of the Book of Chronicles, 209-307; Ben Zvi, History, Literature and Theology, 195209; Philip R. Davies, "Chronicles and the Definition of 'Israel,"' in What Was Authoritative for Chronicles, 77-88; Klein, 1 Chronicles, 46.

${ }^{128}$ Ben Zvi observes, "Since within the discourses of Yehudite literati, YHWH's instructions to Israel—and the latter's obligations to YHWH-were in the main not dependent on the borders of any polities, including those of Yehud, their sets of accepted discourses demanded that some norms be (at least, from an ideological viewpoint) 
Though other tribal identities persisted, the Chronicler's Benjaminite audience formed the primary constituency of "all Israel" beside the royal and priestly tribes of Judah and Levi in the Persian period. The Chronicler's presentation of Benjamin in relation to the royal tribe of Judah is an important "test case" of the Chronicler's vision of "all Israel."

\subsubsection{Summary}

Such a brief discussion of the Chronicler's main themes and theological emphases cannot do justice to the depth and breadth of the Chronicler's outlook. The goal at this juncture has been to highlight the potential significance of Benjamin and Benjaminites to the Chronicler's theologysignificance that warrants further inquiry. More reflection will be appropriate after a careful study of the "Benjamin content" in the DtrH and Chronicles.

\subsection{HISTORICAL SETTING OF CHRONICLES: PERSIAN YEHUD}

Until recent decades, postexilic biblical texts and the Persian period generally were undervalued in biblical studies. With the advent of new textual and material evidence, as well as new methodologies and interpretive paradigms, ${ }^{129}$ the Persian period is now viewed as central to the development of Jewish religion and the formation of the Hebrew Bible. ${ }^{130}$ Persian studies now dominate the various domains of Hebrew Bible scholarship. ${ }^{131}$

applicable to anyone they considered to be Israel, whether they lived in Yehud or not. As a result, to some extent or on the surface these discourses lead to a partial erasement [sic] of the divide between Yehudite and non-Yehudite Israel" (History, Literature and Theology, 196; emphasis original).

${ }^{129}$ Josef Wiesehöfer, Ancient Persia From 550 BC to 650 AD (trans. Azizeh Azodi; New York: I.B. Tauris, 2001 [1996]); Pierre Briant, From Cyrus to Alexander: A History of the Persian Empire (trans. Peter T. Daniels; Winona Lake, IN: Eisenbrauns, 2002); Amélie Kuhrt, The Persian Empire: A Corpus of Sources from the Achaemenid Period (London: Routledge, 2010 [2007]); Josef Wiesehöfer, “The Achaemenid Empire,” in The Dynamics of Ancient Empires (ed. Ian Morris and Walter Scheidel; Oxford: Oxford University Press, 2009), 66-98.

${ }^{130}$ Armin Siedlecki, “"Persian Period Studies Have Come of Age,”" in Historiography and Identity (Re)formulation in Second Temple Historiographical Literature (ed. Louis C. Jonker; New York: T\&T Clark, 2010), 123-124.

${ }^{131}$ Examples include: Philip R. Davies, ed., Second Temple Studies: 1. Persian Period (JSOTSup 177; Sheffield: Sheffield Academic Press, 1991); Lester L. Grabbe, A History of the Jews and Judaism in the Second Temple Period, Volume 1: Yehud: A History of the Persian Province of Judah (London: T\&T Clark, 2004); Oded Lipschits and Manfred Oeming, eds., Judah and the Judeans in the Persian Period (Winona Lake, IN: Eisenbrauns, 2006); Melody D. Knowles, Centrality Practiced: Jerusalem in the Religious Practice of Yehud \& the Diaspora in the Persian Period (Atlanta: SBL, 2006). Gary N. Knoppers and Bernard Levinson, eds., The Pentateuch as Torah: New Models for Understanding Its Promulgation and Acceptance (Winona Lake, IN: Eisenbrauns, 2007); Oded Lipschits, Gary N. 
This section will very briefly raise several issues relating to the Persian context of Chronicles that affect the present study.

\subsubsection{Persian Empire: History and Sources}

The period of Persian rule in the Levant extends from Cyrus's defeat of the city of Babylon (539 BCE) to Alexander's conquest of the Persian empire (333-330 BCE). ${ }^{132}$ Persian territory at the empire's zenith extended from Iran through Mesopotamia and Syria-Palestine to Egypt, westward to Asia Minor, and eastward to the Indus River.

Wiesehöfer notes that the material and textual witness to the Persian Empire suffers from a variety of weaknesses. First, written sources concerning Persia include hostile Greek sources, and royal inscriptions dominated by royal ideology. Second, since Iranian historical tradition is predominantly oral, it is difficult to discern its Achaemenid traits. Finally, "quantifiable material is rare"; the cuneiform tablets, inscriptions and papyri are limited and chronologically imbalanced. "It is therefore difficult to write a history of events from a Persian perspective or to measure the economic performance of the Achaemenid Empire in any meaningful way and to base demographic, social, and economic statements on statistically sound material."133

Western perception of the Persian Empire has historically been influenced by Greek sources, and by the presentation of Persia in the Hebrew Bible. Deutero-Isaiah and Ezra-Nehemiah, for example, portray Cyrus very positively as YHWH's instrument to defeat Babylon and return the Judahites to their homeland (Isa 44:28-45:5; Ezr 1:1-11). Xenophon and Herodotus likewise present Cyrus as "good, wise and tolerant." 134 The discovery of the "Cyrus Cylinder," in which Cyrus supports the Marduk cult in Babylon after his conquest, has been interpreted as further evidence of a "liberal" policy of religious freedom in conquered lands. ${ }^{135}$

Contemporary scholarship has become more skeptical about such perceptions of the Babylonian and Persian empires and their rulers. For example, Wiesehöfer argues that Cyrus and Xerxes—-his foil in the Greek imagination-may not have governed so differently after all. ${ }^{136}$

Knoppers and Rainer Albertz, eds., Judah and the Judeans in the Fourth Century B.C.E. (Winona Lake, IN: Eisenbrauns, 2007); Louis C. Jonker, ed., Historiography and Identity (Re)formulation in Second Temple Historiographical Literature (New York: T\&T Clark, 2010); Louis C. Jonker, ed., Texts, Contexts and Readings in Postexilic Literature (Tübingen: Mohr-Siebeck, 2011); Erhard S. Gerstenberger, Israel in the Persian Period: The Fifth and Fourth Centuries B.C.E. (trans. Siegfried S. Schatzmann; Atlanta: SBL, 2011 [2005]).

${ }^{132}$ Lindsay Allen, The Persian Empire (Chicago: University of Chicago Press, 2005), 26, 135-144.

${ }^{133}$ Wiesehöfer, "The Achaemenid Empire," 66-67.

${ }^{134}$ Wiesehöfer, Ancient Persia, 43.

${ }^{135}$ Grabbe, History of the Jews and Judaism Vol. 1, 111.

${ }^{136}$ Wiesehöfer, Ancient Persia, 42-55. 
Grabbe's assessment of the two empires' attitudes toward local cults is somewhat more moderate than the theological presentation of the Hebrew Bible: "The religious policy of the Persians was not that different from the basic practice of the Assyrians and Babylonians before them." 137

If an early- to mid-fourth-century date is ascribed to Chronicles, the question of the strength of the Persian Empire could influence the book's outlook on the foreign power, royal ideology, and regional politics. The ancient Greeks interpreted Alexander's rapid conquest of the Persian Empire as a sign of economic, military and moral decline. The Greeks perceived a decadent, despotic, weakening monarchy in the later Achaemenid period, which they found antithetical to their ideals of government-ideals represented in Persia most closely by a romanticized Cyrus. ${ }^{138}$ More recent reconstructions have called this "decline model" into question, arguing that the late Achaemenid Empire, while suffering from inefficiencies and inadequacies common to large empires before and after it, was not in decline economically, administratively or militarily. ${ }^{139}$ Rather, the fall of the empire was due primarily to an exogenous factor: "the outstanding military and tactical skill of its military opponent."140

\subsubsection{Persian Provincial Setting}

The Persian administrative hierarchy does not appear to have been uniform across all areas throughout the Persian period. The primary administrative units were regions governed by satraps. The empire was divided into twenty or more satrapies, most of which were subdivided into provinces or districts. ${ }^{141}$ In addition to satraps, "the king occasionally appointed commanders, usually members of the royal family, with wider regional powers over several provinces and their governors. ${ }^{142}$ Furthermore, certain regions, families or special interests were at times represented directly in the king's court. ${ }^{143}$

${ }^{137}$ Grabbe, History of the Jews and Judaism Vol. 1, 273; cf. 215-216.

${ }^{138}$ Wiesehöfer, "The Achaemenid Empire in the Fourth Century B.C.E.: A Period of Decline?" in Judah and the Judeans in the Fourth Century B.C.E., 12-18.

${ }^{139}$ Wiesehöfer, "The Achaemenid Empire in the Fourth Century B.C.E.," 22-28; Briant, From Cyrus to Alexander, 866-876.

${ }^{140}$ Wiesehöfer, "The Achaemenid Empire in the Fourth Century B.C.E.," 28.

${ }^{141}$ Grabbe, History of the Jews and Judaism Vol. 1, 132-134.

${ }^{142}$ Allen, The Persian Empire, 113. See also Gerstenberger, Israel in the Persian Period, 56.

143 "Subject peoples or cities could aspire to having their own representative in the royal court itself, or could establish their communication with the king as he moved between capitals or went on campaign" (Allen, The Persian Empire, 113). 


\subsubsection{Stability of the Persian Hierarchy}

The selectorate theory of political economy (as introduced in the previous chapter) helps explain the relative stability and longevity of the Persian Empire. The Persian kings relied on the loyalty of regional rulers - satraps and governors - to maintain peace and keep tax revenue flowing to the imperial coffers. ${ }^{144}$ Furthermore, the Persian kings required the continued support of the Persian ruling class and the extended members of the royal family. ${ }^{145}$ Persian kings valued loyalty $^{146}$ and rewarded the regional elites and members of the court with patronage.

There were numerous rebellions and contested successions during the Achaemenid period, including the accession of Darius I, various so-called "Satraps' Revolts" (c. 370-360), ${ }^{147}$ and the accession of Darius III. ${ }^{148}$ In each case, a prospective leader tried to defeat the present leader (usurp) or to create a separate polity (rebel) by garnering support of a winning coalition among selectorate members in the kings court or in the "separating" political entity.

The empire itself retained its cohesion and relative stability despite these disturbances, because the institutional political constraints - the sizes of the selectorate and the winning coalition-remained fairly constant. Even though the members of the small selectorate (regional rulers and court elites) competed with one another and rearranged into various winning coalitions, each was invested in the patronage system and desired to keep the selectorate small so as to protect their share of private goods from the king. Allen observes:

The high degree of competition within the Persian ruling class to which political events testify kept a degree of flexibility in the Achaemenid monarchy....[Darius III's] success is an illustration of how close to kingship the satellite members of the royal family could see themselves to be. Their ambitious jostling gave Persian rule a substantial safety net of personnel who had a great investment in the empire, and who could step into a breach when the whole superstructure was threatened. ${ }^{149}$

Though a king himself was not always secure in his position, the monarchy as an institution was secure.

\footnotetext{
${ }^{144}$ Allen, The Persian Empire, 119.

${ }^{145}$ Allen, The Persian Empire, 109.

${ }^{146}$ Allen, The Persian Empire, 98, 100, 104.

${ }^{147}$ Briant, From Cyrus to Alexander, 656-675; Allen, The Persian Empire, 107-109.

${ }^{148}$ Briant, From Cyrus to Alexander, 769-780; Allen, The Persian Empire, 109.

149 Allen, The Persian Empire, 109. Allen (108) and Briant (From Cyrus to Alexander, 680-681) also highlight
} the role of flourishing court factions in the contested succession after the long reign of Artaxerxes II. The competing factions were empowered by patronage, which they could share while Artaxerxes II was alive, but his death left a vacuum that only one faction could fill: "the selection of a crown prince did not result in sharing power" (Briant, From Cyrus to Alexander, 681). 
Competitive political economies also existed in the various regions and provinces of the empire. The conquering kings sought a balance between ultimate control through military presence and reliable channels of communication, and delegation of power to the subordinate rulers of administrative districts. ${ }^{150}$ A further balance appears to have been struck between various channels of royal patronage. The satraps and governors wielded power to levy taxes and distribute private goods, but other direct channels to the king existed as well:

Persian control of the resources of subject lands worked through two main mechanisms: obligatory contribution of tribute and semi-obligatory gifts and the management of Persian-owned estates and businesses....Court stories and letters of appeal focus on the rewards and advantages which the king could bestow on individual subjects and interest groups from his exclusive resources. ${ }^{151}$

The existence of competing channels of power, as well as the competition among individual elites to establish themselves in those channels of power, characterizes the Persian provincial governance as a large-selectorate, small-winning-coalition political economy. Such an arrangement is advantageous for the leader (king), because it produces loyal winning-coalition members who fear replacement by other members of the selectorate.

\subsubsection{Yehud and the Jerusalem Cult in the Persian Hierarchy}

The province of Yehud was part of the Transeuphrates (Ebir-nari; Hebrew עבר הנהר, Aramaic עבר נהרה) satrapy. ${ }^{152}$ The exact subdivisions of Palestine are "only partially known." ${ }^{\text {"153 Alt }}$ proposed that Yehud was not a self-standing province but was in fact under the jurisdiction of Samaria during the Babylonian and Persian periods, but archaeological evidence now confirms that Yehud (at least for a time) was considered its own province with separate governors. ${ }^{154}$ Grabbe

${ }^{150}$ Gerstenberger, Israel in the Persian Period, 55.

${ }^{151}$ Allen, The Persian Empire, 119.

152 The Transeuphrates together with Babylonia may have formed a single satrapy until Darius I (522/521); see Oded Lipschits, "Achaemenid Imperial Policy, Settlement Processes in Palestine, and the Status of Jerusalem in the Middle of the Fifth Century B.C.E.," in Judah and the Judeans in the Persian Period, 24-25.

${ }^{153}$ Grabbe, History of the Jews and Judaism Vol. 1, 134.

${ }^{154}$ Grabbe, History of the Jews and Judaism Vol. 1, 140-142; Charles E. Carter, The Emergence of Yehud in the Persian Period: A Social and Demographic Study (JSOTSup 294; Sheffield: Sheffield Academic Press, 1999), 279280. See also Ephraim Stern, "New Evidence on the Administrative Division of Palestine in the Persian Period," in Achaemenid History IV: Centre and Periphery (ed. Heleen Sancisi-Weerdenburg \& Amélie Kuhrt; Leiden: Nederlands Instituut Voor Het Nabije Oosten, 1990), 223. 
does not rule out the possibility of "a period without a governor or without some other sort of temporary arrangement," i.e., Yehud under the jurisdiction of Samaria. ${ }^{155}$

The governors (פחות) of Yehud that are known from literary and epigraphic sources appear to have been appointed from among the Yehudians themselves, following the Persian practice. ${ }^{156}$ The high priests also held power and worked alongside the governors at times (for example, Zerubbabel and Jeshua: Ezr 4-6; Hag 1-2; Zech 4). ${ }^{157}$ It also appears that the governor could exercise authority to override the priestly and Levitical authority as he saw fit, if Neh 13 provides a reliable example. ${ }^{158}$

The existence and extent of an official relationship between the royal court and the Jerusalem cult is disputed. Central to this question is the historical value of the Persian royal decrees presented in Ezra-Nehemiah (Ezr 1:1-1; 6:1-12; 7:11-26; Neh 2:1-12). ${ }^{159}$ While there is reason to doubt that the Persian government would have provided financial support for the cult of an obscure people in an insignificant region, allowing the Yehudians to return to Yehud and reestablish the cult appears to be consistent with Persian imperial policy ${ }^{160}$ and could have bolstered Yehudian support (however insignificant) for Persian rule. ${ }^{161}$ It would certainly be expected that any correspondence between the royal court and the returning golah leadership (or the Jersualem cult leadership) would have been stylized and magnified by the author(s) of Ezra-Nehemiah. ${ }^{162}$

Weinberg's influential Bürger-Tempel-Gemeinde hypothesis envisioned Persian Yehud as a royally-authorized community centered around a temple controlled by its citizens. ${ }^{163}$ In this view, the returnees were originally commissioned by Cyrus as an attempt to create an economic foothold

${ }^{155}$ Grabbe, History of the Jews and Judaism Vol. 1, 142.

${ }^{156}$ Grabbe, History of the Jews and Judaism Vol. 1, 148-149, 154.

${ }^{157}$ Grabbe, History of the Jews and Judaism Vol. 1, 147.

${ }^{158}$ Grabbe, History of the Jews and Judaism Vol. 1, 147, 310-313.

${ }^{159}$ Grabbe outlines the main evidence for and objections to the authenticity of these decrees (History of the Jews and Judaism Vol. 1, 271-276, 278-285, 295-298, 325-326). Grabbe is skeptical of the decrees recorded in the book of Ezra but more open to a historical basis for Nehemiah's story of royal commission.

${ }^{160}$ Grabbe, though skeptical of the Cyrus decree, allows this point—-though he generally emphasizes the apparent continuity of Persian religious policies with those of the previous empires (History of the Jews and Judaism Vol. 1, 275).

161 "Civic sanctuaries and regional pantheons, when relevant and convenient, could be cultivated and drafted into a recognition of Achaemenid rule" (Allen, The Persian Empire, 125).

162 "Royal letters granting rights to a community could be enshrined and transformed through oral or written tradition in local histories" (Allen, The Persian Empire, 116).

${ }^{163}$ Joel P. Weinberg, The Citizen-Temple Community (trans. Daniel L. Smith-Christopher; JSOTSup 151; Sheffield: JSOT Press, 1992). For a discussion and critique of Weinberg's theory, see Peter R. Bedford, Temple Restoration in Early Achaemenid Judah (JSJSup 65; Leiden: Brill, 2000), 207-230. 
in Palestine in preparation for an invasion of Egypt, but the returning community was rather small and was governed as part of the Samaria province until the mid-fifth century. ${ }^{164}$ Yehud and its cult subsequently benefitted from a tax-exempt status in the mid- to late-fifth century after the edict of Artaxerxes, which swelled the population of Yehud. ${ }^{165}$

Grabbe argues that the imperial government was generally ambivalent about religion and would not have granted a special tax-exempt status to the Jerusalem cult, much less funded its restoration. ${ }^{166}$ In his view, any relationship between the cult and the imperial government was mediated through the governor, who was responsible for collecting the required tax revenue and keeping the peace. In this view, the Jerusalem cult was not a separate channel for royal patronage that would have competed with the governor (of either Yehud or Samaria); rather, the cult was subordinate to the governor of Yehud.

Though Grabbe's model seems more likely given recent models of the settlement patterns of Yehud in the sixth and fifth centuries, both models share the understanding that a temple in Jerusalem provided economic benefit to Yehud that could potentially have come at the expense of the surrounding provinces. In one scenario, the cult enjoyed power through some sort of subsidy or tax benefit parallel to and outside of the power of the provincial government; in the other scenario, the cult was a boon to Yehud's provincial tax base (administered by the governor) because of wealthy patrons drawn from towns bordering other provinces. In either sort of scenario, the governors of neighboring provinces had good reason to oppose a competing center of economic activity in the region (Ezr 4-6).

The question of Yehud's relation to Samaria in the Persian period is particularly relevant to this study, since many of the issues that pertain to the Chronicler's attitude toward the Northern tribes relate to the Chronicler's portrait of Benjamin, and vice-versa. If Benjamin was the significant "other" (in relation to Levi and Judah) closest in proximity to Jerusalem, Samaria was only one additional step removed geographically and ideologically.

After a decline in the late eighth century due the devastation wrought by the Assyrian armies, the city of Samaria itself and the Samarian region appear to have recovered in the seventh century-for some areas, the recovery was quite rapid. ${ }^{167}$ The region appears to have experienced continuity of settlement and even expansion during the neo-Babylonian and Persian periods. ${ }^{168}$

\footnotetext{
${ }^{164}$ Weinberg, Citizen-Temple Community, 131.

${ }^{165}$ Weinberg, Citizen-Temple Community, 117.

${ }^{166}$ Grabbe, History of the Jews and Judaism Vol. 1, 274.

${ }^{167}$ Gary N. Knoppers, "Revisiting the Samarian Question in the Persian Period," in Judah and the Judeans in
} the Persian Period (ed. Oded Lipschits and Manfred Oeming; Winona Lake, Ind.: Eisenbrauns, 2006), $268-269$.

${ }^{168}$ Knoppers, "Revisiting the Samarian Question," 269, 272. 
Material evidence suggests that "the city of Samaria prospered and grew during much of the Persian era," possibly becoming "the largest and most important city of Palestine" during this period. ${ }^{169}$ Knoppers suggests that Samaria's size and prominence relative to Yehud was not lost on the Yehudian elites:

\begin{abstract}
The Jerusalem of the Achaemenid era has been described as a village with an administrative center. In contrast, the Samaria of the Achaemenid era has been described as one of ancient Palestine's larger urban areas: If so, we are dealing not with a situation of comparability but with a situation of disparity. One regional center was substantially larger and wealthier than the other. The difference between the two provinces and their two capitals cannot but have affected the intelligentsia of Jerusalem. During the Achaemenid era, members of the Judean elite were not dealing with a depopulated outback to the north. Quite the contrary, they were dealing with a province that was larger, better-established, and considerably more populous than was Yehud. ${ }^{170}$
\end{abstract}

The implications for our understanding of the Chronicler's message and audience are significant. No doubt some Benjaminites living between the historically Judahite region and the Josephite region would have found religious and economic association with the Samarian province-which was culturally and historically similar to Yehud but more prosperous - to be more advantageous than association with Yehudian institutions like the Jerusalem temple. Knoppers observes, "If, as recent excavations suggest, some sort of sanctuary or temple existed on Mt. Gerizim already during the Persian Period, this would only have added further impetus for Jerusalem Temple scribes to authenticate the distinctive positions of their city and shrine."171

\title{
3.4.2.3 Summary
}

The reconstruction of the power structures within Yehud relative to the Persian Empire can be summarized in the following points:

1) Competitive political economies stabilized the empire as a whole, but created dynamic political situations in the royal court and in the provinces.

2) Yehud was governed as a self-standing province separate from Samaria. Primary authority in Yehud was vested in the governor by the Persian hierarchy. Above the governor were (at least) the satrap and the king.

3) The leadership of the Jerusalem cult wielded some social and economic power in the region. Even if the Persian government did not offer subsidy or tax benefit to the cult, the royal

\footnotetext{
${ }^{169}$ Knoppers, "Revisiting the Samarian Question," 271.

${ }^{170}$ Knoppers, "Revisiting the Samarian Question," 272-273.

${ }^{171}$ Knoppers, "Revisiting the Samarian Question," 279.
} 
authorization of the cult granted it regional significance, which led to the economic benefits of religious activity. Thus, the governor and the high priest competed with one another for prominence.

4) Sociopolitical institutions competing with one another to varying degrees included but were not necessarily limited to: the Yehudian governor, the Samarian governor, the Jerusalem cult, the Mt. Gerizim cult, and other cultic centers.

\subsubsection{Influence of Persian Context on the Chronicler's Thought?}

Various evidences of Persian ideological influence on Chronicles have been suggested. However, it is difficult to know how much to make of such correlations. The historical witness to Persian thought, as we have already seen, is limited in volume and scope. Some suggested parallels between Chronicles and Persian thought could be explained merely as features of ancient Near Eastern texts generally.

The Persian royal propaganda, like the propaganda of the empires to which it was heir, proclaimed that its kings had been divinely chosen ${ }^{172}$ to bring peace to all its constituent peoples. ${ }^{173}$ Though the Persian kings did not hesitate to use the violent tactics of their predecessors, they more successfully avoided such violent conflicts by flexible, decentralized administration of the empire, declining to "impose hierarchization on the divine sphere (the local divinities were not subordinated to Auramazda)," and avoiding “mass deportations on an Assyrian or Roman scale.",174

The Chronicler's choice (or the choice of an editor) to connect the past to his own era with Cyrus's decree reflects a positive view of the Persian Empire. The Persian royal ideology focused on peace, loyalty, and wise administration ${ }^{175}$ - traits that the Chronicler ascribes to the successful ancient kings of his own people. For example, the Chronicler's preference for David's contribution to the cultic and civil administration of Israel over his legendary military exploits (1 Sam 17-18) and hunting prowess (1 Sam 17:34-36) perhaps reflects a Persian royal ideal more than a neoAssyrian or neo-Babylonian royal ideal. ${ }^{176}$

172 The kings were understood chosen of the gods, not gods themselves: "Persian kings were not conceived as divine in their own milieu (the mantle of divinity descended only where regional kingship traditions, as in Egypt, required it)" (Allen, The Persian Empire, 126).

${ }^{173}$ Josef Wiesehöfer, "From Achaemenid Imperial Order to Sasanian Diplomacy: War, Peace, and Reconciliation in Pre-Islamic Iran," in War and Peace in the Ancient World (ed. Kurt A. Raaflaub; London: Blackwell, 2007), 124.

\footnotetext{
${ }^{174}$ Wiesehöfer, "From Achaemenid Imperial Order to Sasanian Diplomacy," 126.

${ }^{175}$ Wiesehöfer, "From Achaemenid Imperial Order to Sasanian Diplomacy," 127.

${ }^{176}$ But, it should also be acknowledged that the Achaemenid rulers integrated Assyrian and Babylonian
} hunting and warring ideals into their royal propaganda; see Allen, The Persian Empire, 98-100. 
The Chronicler's presentation of a Table of Nations (1 Chr 1) and royal and priestly genealogies (1 Chr 3; 6), reflects concern for antiquity and the interconnectedness of nations. ${ }^{177}$ The Persian kings recognized their dependence upon the ancient past and sought to connect themselves to the kings, cults and literature of the empires that preceded them. ${ }^{178}$

The discovery of Greek-style and Persian-style cultic figurines in Yehud from this period confirms the written testimonies - the biblical texts, not least - that centralized, exclusivist, "iconoclastic," monotheistic Yahwism was not the only type of religious practice in this period. ${ }^{179}$ But it is unclear whether Zoroastrianism - the "official" Persian religion—had any influence on the religious beliefs and practices of Yehudians in Yehud or elsewhere. ${ }^{180}$

In summary, while certain connections have been suggested, it is difficult to argue that Chronicles exhibits significant Persian ideological influence. The economic and political circumstance of Yehud within the Persian Empire appears to be more relevant to the study of Chronicles than Persian ideology itself.

\subsection{SUMMARY}

This chapter has attempted to situate the study of the book of Chronicles in literary and historical context by applying the critical methodologies outlined in the previous chapter.

Chronicles is a complex literary work produced in a culturally rich and important period of Jewish history. The debates surrounding the background, authorship and interpretation of Chronicles will continue.

Having considered the critical debates most relevant to the present study and gauged the relevance and impact of the different positions, the next chapter will focus on the tribe of Benjamin in history and literature. We will consider numerous earlier studies on Benjamin, Saul, and

${ }^{177}$ Gary N. Knoppers, "Shem, Ham and Japheth: The Universal and the Particular in the Genealogy of Nations," in The Chronicler as Theologian, 13-31. Allen observes, "When Achaemenid kings talked of the extent of their kingdom, they listed and showed ranks of peoples, rather than geographical limits. The organization of these lists in the royal inscriptions, moving from centre to peripheries, suggests that the peoples were thought of in a spatial sense, giving them a meaning very close to "countries"” (The Persian Empire, 111).

${ }^{178}$ Allen, The Persian Empire, 25-29.

${ }^{179}$ Gerstenberger (Israel in the Persian Period, 42-43) takes issue with Ephraim Stern's interpretation of the relatively small number of cultic figurines discovered (Material Culture of the Land of the Bible in the Persian Period 538-332 B.C. [Jerusalem: Israel Exploration Society; Warminster: Aris \& Phillips, 1982], 158). Nevertheless, the relevant point for this study is the presence of other forms of religious expression in and around Yehud, which is not in dispute.

${ }^{180}$ Grabbe, History of the Jews and Judaism Vol. 1, 362-363. 
intertribal relations, in anticipation of a fresh and comprehensive empirical study of Benjamin in the DtrH and Chronicles. 


\section{Chapter 4: Benjamin in History and Literature}

The preceding chapter raised various historical, literary and theological issues surrounding the book of Chronicles that are relevant to the study of the tribe of Benjamin and intertribal relations. The purpose of this chapter is to provide a survey and preliminary synthesis of scholarly inquiry on the tribe of Benjamin and its significance in ancient Israelite history, in preparation for a comprehensive empirical study of Benjamin in the DtrH and Chronicles.

The introductory chapter offered eight premises that form the structure of this study. The goal of this chapter is to establish and support the third and fourth premises: the unique historical importance of Benjamin to Yehud in the Persian period, and the complex intertribal relationship between Judah, Levi and Benjamin as reflected in the literature of the period. To that end, this chapter is divided into three sections: a reconstruction of the history of the tribe of Benjamin; a brief examination of the general portrait of Benjamin and Benjaminite figures in biblical literature; and a survey of recent scholarship on Saul in the DtrH and Chronicles, with special attention to Saul's relevance in the Persian period. ${ }^{1}$

\subsection{HISTORY OF BENJAMIN}

A "quest for the historical Benjamin" is fundamentally a quest for historical Israel, since Benjaminite territory and figures comprise the geographic and literary center of the narratives of Israelite origins in Palestine. ${ }^{2}$ The difficulties inherent in a quest for historical Israel will therefore also be the central problems of a reconstruction of the history of Benjamin.

First, archaeological reconstructions are always provisional and can only provide certain types of evidence, such as settlement patterns—not necessarily the identities or self-understandings of the inhabitants of the various settlements. In one sense, the very notion of a "Benjaminite tribal region" is strictly a construct brought to the material evidence-unlike, for example, the notion of a "Yehud Province" in the Persian period, for which material evidence exists. Benjaminite identity and Benjaminite regional boundaries are known only from the texts of the Hebrew Bible. This does

${ }^{1}$ While every effort will be made to provide brief engagements with only the most relevant studies, the sheer volume of the scholarly literature on Benjamin (if nothing else) should convince the reader of the importance of Benjamin, Benjaminites and Benjaminite identity for study of the Hebrew Bible and ancient Israel.

${ }^{2}$ Avraham Faust, "Settlement Patterns and State Formation in Southern Samaria and the Archaeology of (a) Saul," in Saul in Story and Tradition (ed. Carl S. Ehrlich and Marsha C. White; FAT 47; Tübingen: Mohr-Siebeck, 2006), 14. 
not mean that information found in the Hebrew Bible about Benjamin cannot provide valid explanations for the material evidence, but it does require us to recognize the limits of both "biblical" reconstructions and archaeological reconstructions.

Second, the biblical narratives themselves portray the borders of Benjaminite territory as shifting over time. ${ }^{3}$ The apparent fluidity of the borders of Benjaminite, Northern/Samarian, Judahite, and Philistine territories makes definite, precise statements about the interactions between these groups quite difficult. Certain towns and cities appear to have been continuously settled for long periods of time and are consistently listed as belonging to Benjamin in the Hebrew Bible; these might be called "Benjaminite" with reasonable confidence.

Third, the written evidence for the history of Benjamin is embedded within the decidedly pro-Judah, pro-Levi biblical texts. At the heart of the present study is the notion that the biblical portraits of Benjamin are not always hostile—but some biblical portraits certainly are hostile to Benjamin and should be appropriately discounted, though not discarded, for the purpose of historical reconstruction.

In accordance with the principles outlined in chapter two, this reconstruction of Benjamin's history will attempt to balance archaeological and literary (biblical) evidence-neither of which could on its own produce a meaningful, accurate picture of the past. Particular weight in the literary evidence should be given to three sorts of elements of the biblical narratives concerning Benjamin: 1) elements that seem to be at odds with the apparent intention of the text;2) elements about which the author and his contemporary opponent would likely agree; and 3) elements which appear to be incidental or unrelated to the intention of the text. ${ }^{4}$

\subsubsection{Origins of Israel in the Benjaminite Region}

K.-D. Schunck conducted one of the earliest studies (1963) of the origins and background of the tribe of Benjamin. ${ }^{5}$ Schunck subsequently (1992) summarized and updated his findings on Benjamin's origins, and expounded further evidence regarding later tribal history. ${ }^{6}$ Schunck asserted that the clans that would later become Benjamin and Ephraim invaded the Cisjordan region

${ }^{3}$ Faust, "Settlement Patterns," 18-19.

${ }^{4}$ Siegfried Kreuzer, "Saul-Not Always—at War: A New Perspective on the Rise of Kingship in Israel," in Saul in Story and Tradition (ed. Carl S. Ehrlich and Marsha C. White; FAT 47; Tübingen: Mohr-Siebeck, 2006), 42-43.

${ }^{5}$ Klaus-Dietrich Schunck, Benjamin: Untersuchungen zur Entstehung und Geschichte eines israelitischen Stammes (BZAW 86; Berlin: Alfred Töpelmann, 1963).

${ }^{6}$ Schunck, "Benjamin,” Anchor Bible Dictionary, vol. 1. (trans. Phillip R. Callaway; ed. David Noel Freedman; New York: Doubleday Publishing, 1992), 671-673. 
in the thirteenth century under Joshua, and that Benjamin nearly ceased to exist during the time of the judges (cf. Jdg 19-21). ${ }^{7}$

Compromise was a hallmark of Benjamin's tribal history. Given Joshua's identification as an Ephraimite, this Benjaminite conquest is evidence of "a close connection between the Benjaminite and Ephraimite clans even before the conquest, perhaps in the form of a military coalition." ${ }^{8}$ Schunck notes that the sanctuary at Gilgal (Josh 4-5) lies on the border between the Benjaminite and Ephraimite regions ${ }^{9}$ - perhaps a foreshadowing of the later compromise between Judah and Benjamin embodied in the choice of the threshing floor of Ornan the Jebusite as the temple site. ${ }^{10}$

More recent studies tend to affirm that the Israelite monarchy originated in and around the land of Benjamin. ${ }^{11}$ Material evidence points to the formation of an Israelite state around the turn of the first millennium, resulting from an increase in population in southern Samaria. Scholars differ on the extent to which the establishment of a state should be attributed primarily to the Philistine threat, ${ }^{12}$ or to internal factors such as societal and economic complexity accompanying population growth. ${ }^{13}$ It is likely that both internal and external factors contributed to the establishment of the state. Faust argues that this reconstruction accords broadly with the biblical account of the formation of the Israelite monarchy:

In its general outlines the archaeological analysis agrees with the biblical narrative concerning the time and place where the initial stages in the formation of the Israelite monarchy occurred....It seems that the archaeological/anthropological literature clearly indicates that similar processes do not take

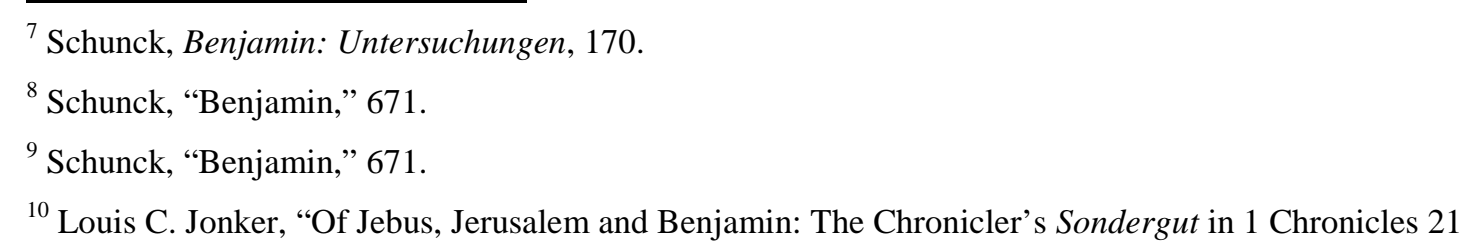
Against the Background of the Late Persian Era in Yehud," in Chronicling the Chronicler: The Book of Chronicles and Early Second Temple Historiography (ed. Tyler F. Williams and Paul S. Evans; Winona Lake, IN: Eisenbrauns, 2013), $81-102$.

${ }^{11}$ Faust, "Settlement Patterns," 14.

${ }^{12}$ Lawrence E. Stager, "Forging an Identity: The Emergence of Ancient Israel," in The Oxford History of the Biblical World (ed. Michael D. Coogan; New York: Oxford University Press, 1998), 171; Faust, "Settlement Patterns," 14-17. See also the discussions in essays that propose alternate theories: Israel Finkelstein, "The Emergence of the Monarchy in Israel: The Environmental and Socio-economic Aspects," JSOT 44(1989): 44-46; and Kreuzer, "Saul— Not Always-at War," 39-41.

${ }^{13}$ Finkelstein, "The Emergence of the Monarchy in Israel," 46-74. Daniel Master proposes that Weber's patrimonial model of social authority, in which "the forces of tradition and personal association, natural forces apparent in the ancient household...shape the concept of authority," may provide a better explanation for the emergence if Israelite statehood: "State Formation Theory and the Kingdom of Ancient Israel," JNES 60(2001): 128. 
place without a strong agent. While it is clear that the archaeological record does not provide the name of the agent involved, it seems reasonable and justified, in light of the similarity between the archaeological analysis and the biblical narrative, to borrow the name mentioned in the story, i.e., Saul, and to call the assumed agent by this name. In some contexts, however, it might be safer to refer to $a$ Saul. ${ }^{14}$

Levin echoes this finding, addressing the radical historicist critique (which he terms "unhistorical criticism") of the biblical portrayals of monarchic history by matching the " "traditional' critical understanding" of the origins of Benjamin with the archaeological and biblical evidence. ${ }^{15}$

Schunck suggests a slightly different angle on Saul's appointment as king. He proposes that Saul's selection was a compromise between Judah and Ephraim, since Benjamin had historic ties to both of Israel's strong tribes and was a geographical "middle ground" between the two. ${ }^{16}$ Levin suggests that David and Solomon ruled "Judah" and "Israel" as separate administrative divisions even before the secession of Israel under Rehoboam, and that Benjamin seems to have been part of the Northern administrative division. ${ }^{17}$

The land that became identified with Benjamin seems to have been home to a great number of important cultic sites through much of Israel's history. Langston observes that the within Benjamin's borders-including Gibeon, Jerusalem, Beth-aven, Bethel, Nob, and several others"were more prominent in the Hebrew Bible than their counterparts elsewhere."18

\subsubsection{Divided Monarchy}

During the divided monarchy, Benjamin appears to have played a key role as the border tribe between the Northern and Southern Kingdoms. ${ }^{19}$ The exact nature of that role is the subject of much debate.

Levin observes that the language of the oracles to Solomon and Jeroboam (1 Kgs 11:11-13; 11:29-39) leaves Benjamin's affiliation ambiguous: ten ${ }^{20}$ tribes (vv. 31, 35) are torn from David's

\footnotetext{
${ }^{14}$ Avraham Faust, "Settlement Patterns," 34 (emphasis original).

15 Yigal Levin, “Joseph, Judah and the 'Benjamin Conundrum,"” ZAW 116 (2004): 223-241.

${ }^{16}$ Schunck, Benjamin: Untersuchungen, 171.

${ }^{17}$ Levin, "Benjamin Conundrum," 226-227.

${ }^{18}$ Scott M. Langston, Cultic Sites in the Tribe of Benjamin: Benjaminite Prominence in the Religion of Israel
} (New York: Peter Lang Publishing, 1998), 27-28.

${ }^{19}$ Schunck, Benjamin: Untersuchungen, 171-172.

${ }^{20}$ The association of "ten tribes" is itself a stylization, since Simeon's region was contained within Judah's (Josh 19:9), and was apparently later absorbed into Judah: “The pattern of Judahite domination over and even absorption of Simeon is strongly suggested by the Deuteronomistic work" (Gary N. Knoppers, 1 Chronicles 1-9 [Anchor Bible Commentary; New York: Doubleday, 2004], 372). The Northern faction in Rehoboam's day would only 
line, and only one is left for David (vv. 13, 32, 36). ${ }^{21}$ Levin argues that from the beginning of the period of divided monarchy the land of Benjamin was divided, torn between stronger ties to the north and southern kings attempting to create a buffer for their capital:

Rehoboam [mustered] all of his influence and power, whether military, economic or political, in order to retain control over the border regions. In the end he was only partially successful. The border was set at Mizpah; towns to the north such as Bethel and Ophrah with their Benjaminite clans remained in Israel. ${ }^{22}$

Over time, southern Benjaminites came to identify themselves as a minority within Judah, while "[retaining] familial ties with their brethren 'across the border.", 23 The biblical secession story reflects an exilic or post-exilic stage of Benjaminite affiliation with Judah.

Davies rejects the idea that the North—which included Benjamin-was ever ruled by a Judahite king. ${ }^{24}$ Challenging Schunck's acceptance of the biblical assertion that from the time of Rehoboam onward Benjamin was associated with Judah (1 Kgs 12), ${ }^{25}$ Davies argues rather that Benjamin was part of the Northern Kingdom until 722, when the conquering Assyrians "may have decided to grant this territory to their loyal allies": the kingdom of Judah. ${ }^{26}$ After Sennacherib subjugated all Judah but Jerusalem, Josiah may have subsequently reasserted temporary control of Benjaminite territory. ${ }^{27}$ After the Babylonian conquest, the tables were somewhat turned: the province of Judah was ruled from a Benjaminite administrative center (Mizpah), and its primary cultic centers appear to have been Benjaminite as well (Mizpah, Bethel, Gibeon). ${ }^{28}$

have included nine tribes: Reuben, Gad, Dan, Asher, Naphtali, Zebulun, Issachar, Manasseh, and Ephraim—and possibly Benjamin, which is the very question at hand.

21 "I would suggest that rather than this being bad addition in an unskillfully told story, it is a purposeful reflection of the unclear status of the twelfth tribe, namely Benjamin, once again in an oracle attributed to a northern prophet" (Levin, "Benjamin Conundrum," 229n27).

${ }^{22}$ Levin, "Benjamin Conundrum," 229.

${ }^{23}$ Levin, "Benjamin Conundrum," 230.

${ }^{24}$ Philip R. Davies, “The Trouble With Benjamin,” in Reflection and Refraction: Studies in Biblical Historiography in Honour of A. Graeme Auld (ed. R. Rezetko et al.; Leiden: Brill, 2007), 102.

${ }^{25}$ Schunck, Benjamin: Untersuchungen, 139-69.

${ }^{26}$ Davies, "The Trouble With Benjamin," 103-104.

${ }^{27}$ Davies, "The Trouble With Benjamin," 103. Ernst A. Knauf argues that Benjamin, "the Israelite south," was annexed to Judah between 630 and 620 BCE: "Bethel: The Israelite Impact on Judean Language and Literature,” in Judah and the Judeans in the Persian Period (ed. Oded Lipschits and Manfred Oeming; Winona Lake, IN: Eisenbrauns, 2006), 316.

${ }^{28}$ Philip R. Davies, "The Origin of Biblical Israel," in Essays on Ancient Israel in Its Near Eastern Context: A Tribute to Nadav Na'aman (ed. Yairah Amit et al.; Winona Lake, IN: Eisenbrauns, 2006), 142-144. 
Na'aman is critical of such attempts by Davies and others to associate Benjamin solely with the Northern Kingdom from its earliest stage - a tendency which, he suggests, is based on the biblical story of Benjamin and Joseph as sons of Rachel. ${ }^{29} \mathrm{Na}$ 'aman argues that from its earliest history ${ }^{30}$ the Benjaminite region was associated with Jerusalem: "The results of the archaeological research strongly suggest that the highland district of Benjamin was an integral part of the kingdom of Judah in the monarchical period, and that its material culture differs from that of the hill country of Ephraim." ${ }^{31}$ Even though portions of the land of Benjamin were part of the Northern Kingdomnotably Bethel ${ }^{32}$ - most of Benjamin was part of the kingdom of Judah during the divided monarchy. ${ }^{33}$

The scenarios proposed by Levin and $\mathrm{Na}$ 'aman seem to make better sense of the material evidence, and of Knauf's and Davies's own suggestions that the annexation of Bethel was partly the means by which Israelite/Northern traditions (e.g., exodus and judges/saviors traditions) came south to Judah. ${ }^{34} \mathrm{Na}$ 'aman rightly questions why the Assyrians-if they indeed gave the land of Benjamin to Judah after 722 BCE—-would have detached Bethel, an important administrative and cultic center of the conquered Samarian kingdom, and given it to Judah. ${ }^{35} \mathrm{Na}$ 'aman prefers to follow Alt's proposal that "the area of Bethel was annexed to the kingdom of Judah after the Assyrian retreat from Palestine, probably in the 620s BCE."36

Levin argues, contra Davies, that Benjamin's ambiguous, tense relation to Judah throughout the DtrH is strong evidence of the historicity of at least a core of the biblical portrait of the united monarchy. If Benjamin was only annexed involuntarily to Judah after the fall of the Samarian kingdom, what would be the necessity for such a strong Benjaminite "substratum" in such a Judahcentered history—especially the founding of Israel by a Benjaminite king? "

${ }^{29}$ Nadav Na'aman, "Saul, Benjamin and the Emergence of 'Biblical Israel' (Parts 1 \& 2)," ZAW 121 (2009): 335.

${ }^{30} \mathrm{Na}$ 'aman argues that even pre-Israelite, Canaanite Jerusalem of the early second millennium included the territory that later became the land Benjamin: "Canaanite Jerusalem and its Central Hill Country Neighbours in the Second Millennium B.C.E.," UF 24 (1992): 275-291.

${ }^{31} \mathrm{Na}$ 'aman, "Saul, Benjamin and the Emergence of 'Biblical Israel,", 217.

${ }^{32} \mathrm{Na}$ 'aman, "Saul, Benjamin and the Emergence of 'Biblical Israel,'” 338-342.

${ }^{33} \mathrm{Na}$ 'aman, "Saul, Benjamin and the Emergence of 'Biblical Israel,", 224.

${ }^{34}$ Knauf, "Bethel,” 291-295; Davies, "The Trouble With Benjamin,” 104-110.

${ }^{35} \mathrm{Na}$ 'aman, "Saul, Benjamin and the Emergence of 'Biblical Israel,” 339.

${ }^{36} \mathrm{Na}$ 'aman, "Saul, Benjamin and the Emergence of 'Biblical Israel,"” 339.

37 "If, indeed, the whole of the Primary History was first "invented" either during the days of Josiah or in the post-exilic period, based on only a dim recollection of the past at best and perhaps even an intentional attempt to "rewrite" history, then why even mention the northern origin of the Benjaminites and their king Saul? If the whole episode 
reason for such a tradition to be included in the History is that it was known to the people of the authors' own time, forcing them to deal with it." ${ }^{38}$ Rather, Benjamin seems to have been important to Judah from the beginning, since Jerusalemite rulers needed Benjamin's support as a buffer against the North.

Levin, Davies, Na'aman and Knauf observe intertribal tensions embedded in the biblical texts, which reflect Benjamin's status as a border tribe- $\mathrm{Na}$ 'aman sees Benjaminite hostility toward Ephraim, ${ }^{39}$ whereas Davies focuses on Benjaminite hostility toward Judah. ${ }^{40}$ There is no doubt that both observations are correct, reflecting the "tug-of-war" over Benjamin found both in the narratives of 1-2 Kings and in the history of the ninth and eighth centuries BCE.

Economic activity is dynamic; ethnic and religious identities exhibit fluidity and flexibility. Any reconstruction of the political status of Benjamin during the divided monarchy must take these facts into consideration. Given that the written evidence seems to associate Benjamin with both the North and the South, it is reasonable to suggest that some Benjaminite families, settlements and towns switched their primary allegiances (in one direction or the other) at different times. The ethnic/clan association with Ephraim seems to have been stronger, ${ }^{41}$ but the geography of Benjamin made economic, political and military ties with Judah a necessity as well.

Such a scenario assumes a certain measure of autonomy for "Benjamin" as a tribe/province/polity, and for Benjaminite individuals/families. In Knauf's and Davies's proposed scenarios, Benjamin is a passive entity, subjugated in succession by the Samarian government, the conquering Assyrians, the kingdom of Judah, Assyria, and finally Babylon. Yet political boundaries defined by military conquest, treaty, taxation and forced tribute do not always mirror economic, ethnic and religious affiliations. For example, it is perfectly conceivable that individual Benjaminite towns or families paid regular tribute to one larger political entity-and thus would be considered "part" of that entity—while simultaneously identifying ethnically, religiously and economically with another political entity. The material and literary evidence seems to demand nuanced explanations that emphasize complexity and fluidity, rather than proposals that generalize about one kingdom "handing over a region" to another.

of the United Monarchy is no more than a Judean literary invention, why give the "honor" of its foundation to a northerner, whose followers then continued to pester the Messiah David?" (Levin, "Benjamin Conundrum," 231-232)

${ }^{38}$ Levin, "Benjamin Conundrum," 232.

39 "Since the district of Benjamin was a buffer zone between Israel and Judah, and must have suffered in the course of the military clashes between the two kingdoms (as may be inferred from Hos 5:8-9; 9:9; 10:9), it might have grown hostile rather than fraternal in its relations with Ephraim, its northern neighbor" (Na'aman, "Saul, Benjamin and the Emergence of 'Biblical Israel,", 224).

${ }^{40}$ Davies, "The Trouble With Benjamin," 102ff.

${ }^{41}$ Levin, "Benjamin Conundrum," 224. 


\subsubsection{Under Babylonian Rule ${ }^{42}$}

2 Kings 24-25 describes the fall of Judah to Nebuchadrezzar of Babylon, including two stages of forced deportation over eleven years (24:10-17, 598 BCE; 25:8-12, 587 BCE), small territorial losses to smaller peoples (24:2), the complete loss of Judah to Nebuchadrezzar, and the emigration of some Judahites to Egypt (25:26). The summary statement in 25:21b, "So Judah was exiled from its land," corresponds nearly verbatim to the statement of Israel's exile (17:23b). Whereas the Deuteronomist is similarly adamant that Israel is completely removed from its land, 25:12 and 25:22-26 acknowledge that some Judahites were left in the land. ${ }^{43}$

Lipschits has played a significant role in overturning "the myth of the empty land"-it is now widely acknowledged that the lands of the kingdom of Judah were continuously inhabited during the Babylonian period. ${ }^{44}$ In a shorter study, Lipschits examines what is known from archaeological evidence concerning the Benjaminite regions during this period. ${ }^{45}$

Lipschits's most relevant finding for this study is that the Benjaminite regions suffered little from the Babylonian invasion: "Archaeological finds from the Benjamin region... as well as the finds from the northern Judean hill country, indicate continuous settlement in these parts in the sixth century BCE." ${ }^{46}$ Lipschits posits that the two most important Benjaminite sites under Babylonian rule were Mizpah, "an administrative centre” with some wealthy houses, storehouses and fortifications; and Gibeon, which "had great economic importance for the Benjamin region, and it might have served as an industrial centre for the winemaking activity in the region."47

Why did the Benjaminite regions largely escape destruction at the hands of the Babylonians? Some have proposed that key Benjaminite leaders, such as Gedaliah and Jeremiah

${ }^{42}$ The following section develops and elaborates upon my unpublished thesis, "From Time-Bound to Timeless: The Rhetoric of Lamentations and Its Appropriation" (MTh thesis, Stellenbosch University, 2012), 25.

${ }^{43}$ This leads the reader to doubt the earlier contention that ethnic Israelites were completely removed from Samaria.

${ }^{44}$ Oded Lipschits, The Fall and Rise of Jerusalem: Judah Under Babylonian Rule (Winona Lake, IN: Eisenbrauns, 2005); see also Hans M. Barstad, The Myth of the Empty Land: A Study in the History and Archaeology of Judah During the “Exilic” Period (Oslo: Scandinavian University Press, 1996).

${ }^{45}$ Oded Lipschits, “The History of the Benjamin Region under Babylonian Rule,” Tel Aviv 26 (1999): 155-90.

${ }^{46}$ Lipschits, "History of the Benjamin Region," 164. Elsewhere, he notes: "From the foregoing no evidence emerges of destruction at the beginning of the sixth century, apart from the razing of parts of Tell el-Fûl. At all the excavated sites evidence of continuity of settlement exists between the seventh and sixth centuries, and of their existence throughout the time of Babylonian rule, until the last third of the sixth century" ("History of the Benjamin Region," 179).

${ }^{47}$ Lipschits, "History of the Benjamin Region," 179. A cultic center at Mizpah has also been suggested based on Jer 41:5 (Schunck, "Benjamin,” 672-673). 
(not a Benjaminite, but owned land in Benjamin), capitulated to the Babylonians in order to survive. Davies asserts:

Jeremiah has the protection of a powerful lobby that is in favour of capitulation, or that is even proBabylonian....An indication of the (effectively) pro-Babylonian stance of a group with Benjaminite connections is the favour shown to the territory of Benjamin by Nebuchadrezzar after the fall of Jerusalem. ${ }^{48}$

Schunck likewise suggests:

Apparently not touched by Nebuchadrezzar's reduction of the Kingdom of Judah in 597 BCE (cf. Jer $32: 8 ; 37: 12$ ), Benjamin probably served as a center of opposition to the policies of the last Judean king, Zedekiah. The prophet Jeremiah, who spoke vehemently against the anti-Babylonian policies of Zedekiah, came from Anathoth in Benjamin (Jer 1:1). Undoubtedly, Benjaminite territory remained unscathed in the destruction of 587 BCE because of this disposition within Benjaminite circles. It was therefore only a matter of course that the Benjaminite city Mizpah became the administrative seat of the highest ranking, native official installed by the Babylonians over the annexed area (2 Kgs 25:2223; Jer 40:6) after the dissolution of the kingdom of Judah. ${ }^{49}$

Interpreting Jeremiah's actions somewhat more empathetically, Seitz associates Jeremiah with a group called "the people of the land" (עם הארץ), who frequently opposed the Jerusalem nobility in the later stages of the kingdom of Judah. The עם הארץ, in this view, are rural inhabitants of Judah and Benjamin (and refugees from Israel) who are connected with "early traditions and traditionalists of Deuteronomy." 50 The "actively engaged in dynastic affairs" from time to time," including the overthrow of Athaliah (2 Kgs 11) and Amon (2 Kgs 21:24). The conflict between views intensified after Sennacherib's invasion of Judah and the later incursions by the Babylonians and others ( $2 \mathrm{Kgs} 24: 2$ ), during which many rural Judahites took refuge within Jerusalem. ${ }^{52}$

Seitz's proposal accounts for similarities in attitude and content between Deuteronomy and Jeremiah, since Jeremiah himself had a background similar to that of the עם הארץ: a refugee to

\footnotetext{
${ }^{48}$ Davies, "Trouble with Benjamin," 98, 100.

${ }^{49}$ Schunck, "Benjamin," 672.

${ }^{50}$ Christopher Seitz, Theology in Conflict: Reactions to the Exile in the Book of Jeremiah (Berlin: de Gruyter,
} 1989), 69.

${ }^{51}$ Seitz, Theology in Conflict, 67.

${ }^{52}$ See also Lisbeth S. Fried, "The 'am hā' àreș in Ezra 4:4 and the Persian Imperial Administration," in Judah and the Judeans in the Persian Period (ed. Oded Lipschits and Manfred Oeming; Winona Lake, IN: Eisenbrauns, 2006), 125-128, 141. 
Jerusalem, he accepted YHWH's judgment for sin through the instrument of Babylon, over-against the faithless "monarchy" of Jehoiakim, Jehoiachin and Zedekiah. ${ }^{53}$

Some Benjaminites were, no doubt, part of the group of refugees to Egypt described in Jeremiah 40-44. However, this group appears to have been insignificant relative to the population of the Benjamin-Judah regions: "The group that left for Egypt was numerically small. It consisted primarily of the 'leaders of the forces' and those who had been released from Ishmael's hands." Some families out of the few Jerusalemites taken to Babylon appear to have been Benjaminite as well, as evidenced by the lists and descriptions of returnees (Ezr 1:5; 4:1-3; Neh 11:4-7, 31-36) and the Benjaminite presence in the Eastern Diaspora (Est 2:5-6). ${ }^{55}$

Thus, at the conclusion of the Babylonian captivity, individuals who identified as "Benjaminite" lived in Egypt, Mesopotamia, and—primarily—in Yehud and southern Samaria, the historically Benjaminite regions.

\subsubsection{Under Persian Rule}

During the postexilic period, the regions of Judah and Benjamin appear to have constituted a single polity within the Persian Empire: Yehud Province. As mentioned above, neither the loss of deportees under Babylonian rule nor the subsequent waves of returnees under early Persian rule appear to have had significant impact on the population of the Benjaminite region.

However, late in the sixth century the land of Benjamin appears to have experienced decline:

From the end of the sixth century and during the fifth and the fourth, settlement in the Benjamin region gradually dwindled. This process may be associated with the shift of the centre of settlement to the Jerusalem area after the Return from the Exile and the decline of the status of Mizpah, together with that of the Benjamin region as a whole. ${ }^{56}$

Schunck suggests that the conflicts described in Ezra between the "people of the land" and the returning golah community may have resulted in the decline of some Benjaminite towns. ${ }^{57}$

${ }^{53}$ Seitz, Theology in Conflict, 69-71.

${ }^{54}$ Lipschits, "History of the Benjamin Region," 164.

${ }^{55}$ Whether or not the narrative of Esther is fictional, the portrait of a Benjaminite Eastern golah/Diaspora is consistent with the other biblical narratives and must have seemed at least plausible to the audience of the book of Esther; see Davies, “Trouble with Benjamin,” 96-98.

${ }^{56}$ Lipschits, "History of the Benjamin Region," 179.

57 “The archaeological record attests to the destruction of numerous Benjaminite towns (Bethel, Gibeon, Gibeah) in the first quarter of the 5th century BCE. The precise significance of this is debated, although it seems to 
If indeed the majority of Benjaminites were not taken to Babylon but remained in Yehud and southern Samaria - as the evidence suggests - the question of the relationship between the returning golah community and the she'erit (those left in the land) becomes crucial for deciphering the literary evidence concerning Benjamin in the Persian period. Who were the opponents of the rebuilding efforts described in Ezra 4-6, and do these accounts have historical value? The opponents of the golah are described as "enemies (צרי) of Judah and Benjamin" (4:1), as "the people of the land (עם הארץ)" (4:4), and as the non-Israelites who were brought by Esarhaddon of Assyria to resettle the Samarian kingdom (4:2; per 2 Kgs 17:23-41).

Grabbe argues that Ezra 1-6 (//1 Esdras 2-7) is a late-Achaemenid or early-Hellenistic literary account of "the Return" that is invested in a theological portrayal of the returnees as "a refined, purified remnant of the community that sinned under the monarchy and was exiled as punishment." ${ }^{, 58}$ Thus, the people of the land are inaccurately portrayed foreigners who would pollute the golah community (Ezr 6:21):

The text [Ezra] simply refuses to admit that there were Jewish inhabitants of the land after the deportations under Nebuchadnezzar. Probably only a minority of the people were taken away, with the tens of thousands still left. These people continued to live in Judah, work the land, raise families, carry on their daily life. Presumably they would have quietly taken over any land abandoned because the owners had been killed in fighting or deported to Babylonia. There is no suggestion that any foreign peoples were brought in to replace those deported. Where are these people-Jews-in the books of Ezra and Nehemiah? They are absent. Instead we find references to the "peoples of the land,' who are identified as foreigners. One can only conclude that many, if not all, these 'peoples of the land' were the Jewish descendants of those who were not deported. In the eyes of the author of Ezra, these peoples were no longer kin; the only 'people of Israel' were those who had gone into captivity. $^{59}$

In Grabbe's view, Ezra anachronistically identifies the she'erit community-which included the majority of Benjaminites — as foreign to Israel, while the only "true Israelites"-including Benjaminites (Ezr 1:5; 4:1-3)—are the golah community.

Fried takes issue with this interpretation, arguing that the author/redactor of Ezra 1-6 has confused the landed aristocracy who opposed the golah rebuilding efforts with the pre-exilic

indicate some disturbances between the Judaean community in Jerusalem and Samaria to its north, possibly related to the political tensions described in Ezra 4" (Schunck, "Benjamin," 673).

${ }^{58}$ Lester L. Grabbe, A History of the Jews and Judaism in the Second Temple Period, Volume 1: Yehud: A History of the Persian Province of Judah (London: T\&T Clark, 2004), 286-287.

${ }^{59}$ Lester L. Grabbe, Ezra-Nehemiah (Old Testament Readings; New York: Routledge, 1998), 138. See also Grabbe, History of the Jews and Judaism Vol. 1, 285-288. 
"people of the land," the landed aristocracy mentioned in the biblical corpus. The true opponents of the golah, according to Fried's reading of Ezra 4-6, were actually "Persian satrapal officials": 60

\begin{abstract}
These satrapal officials held the real political power in the Empire, and as such they formed the landed aristocracy of the satrapy. The meaning of the term did not change, but the people who had previously been designated by the phrase were no longer designated by it. The Judean 'am hà'âreș, the Judean aristocracy who had controlled Judah before the exile, were not in charge of Judah anymore. The land was now in the control of strangers. The Persian and Babylonian officials of the satrapy Beyond the River were the new 'am hà'âreș. They were the ones who administered Judah, and they were foreign. ${ }^{61}$
\end{abstract}

Fried's argument that 'am $h \bar{a}$ 'āreș had become for the author of Ezra a designation/epithet for "wealthy landowner" has merit. However, her argument from the text of Ezra 1-6 that this epithet could only properly refer to Persian officials is less convincing. The officials named in Ezra 4-6 likely owned land, but the "people of the land" designation need not apply exclusively to those officials - the Persians tended to allow local elites to retain power and land ownership. ${ }^{62}$ The 'am $h \bar{a}$ 'ăreș in Ezra 4:4 included wealthy Yehudites, including those identifying as Benjaminites.

Grabbe's assessment of Ezra 1-6's stylized portrayal of the relationship between the returnees and the she'erit is partly correct: the author of this section clearly viewed the golah community as the lone stewards of the true faith of Israel. But Grabbe's interpretation of Ezra's golah ideology is too narrow; the author recounts that "all those who had separated themselves from the uncleanness of the nations of the land" (וכל הנבדל מטמאת גוי־הארץ) celebrated the Passover in the rebuilt temple along with "the sons of Israel who had returned from exile" (Ezr 6:21). ${ }^{63}$ The author may have misunderstood or misconstrued the background of the she'erit community, but he allowed that they could join the golah community by adhering to the "proper" cult.

Political and religious tensions persisted throughout the Persian period, as evidenced by the accounts of the reforms of Ezra (Ezr 7-10; Neh 7) and Nehemiah (Neh 2-13). The exact partisan positions of Benjaminites collectively or Benjaminite individuals in these conflicts are difficult to determine. Given the existence of other Yahwistic cultic sites in and around the Benjaminite

\footnotetext{
${ }^{60}$ Fried, “The 'am hā'āreș in Ezra 4:4,” 130.

${ }^{61}$ Fried, "The 'am hā' āreș in Ezra 4:4," 141.

${ }^{62}$ Lindsay Allen, The Persian Empire (Chicago: University of Chicago Press, 2005), 90, 119.

${ }^{63}$ This open invitation to "separated Israelite brethren" to join the Jerusalem cult and celebrate the Passover
} echoes the "Northern outreach" during the cultic reforms of Hezekiah and Josiah as portrayed by the Chronicler (2 Chr $30: 1-19,35: 17-18)$. 
region—possibly Bethel, ${ }^{64}$ Gibeon, and Gerizim ${ }^{65}$ — it is likely that some Benjaminites were among the opponents (real or imagined) of the Jerusalemite religious party or parties. ${ }^{66}$

Archaeological findings reveal that Yehud was not empty during the Babylonian rule, and that the region traditionally associated with Benjamin prospered during the sixth century. The biblical texts, when properly interpreted as ideological portrayals of the period, lead to the conclusion that at least some of the prosperous she'erit community of early Persian Yehud were Benjaminites, who were influential in provincial government and came into conflict with the returnees. Benjaminites were among the returnees, and some she'erit Yehudians apparently joined with the golah community and associated with the Jerusalem cult.

Though joined inseparably to those of Judahite ancestry and designated as "Jews" (יהודים), Benjaminites retained their separate tribal identity — as did the Levites. Benjaminite identity continued to be relevant to the self-understanding of many Jews in Palestine and the Diaspora well into the Hellenistic period. ${ }^{67}$

\subsubsection{Summary}

Benjamin's historic location made the tribal region a scene of conflict and compromise. During the tribal period and united monarchy, Benjamin was a midway point between the southern faction led by Judah and the larger northern faction led by Josephite tribes. During the divided monarchy, key Benjaminite towns and regions were sometimes associated with the North, sometimes with the South. During the exilic period, Benjamin again rose to prominence as the lone Israelite region that had been mostly unaccosted by (or had capitulated to) the Assyrians or Babylonians. This prominence set the stage for conflict between she'erit Yehudians-some of whom were Benjaminites - and the returning golah elites, who wanted to see Jerusalem regain its primacy. During the Achaemenid and Hellenistic periods, Yehud/Judaea included historically Benjaminite and Judahite territories, which included individuals and towns of diverse cultic, tribal and political affiliations.

${ }^{64}$ Blenkinsopp argues that Hag 2:14, Zech 7:1-3, and Jer 41:4-9 indicate the presence of a temple in Bethel during the Persian period: "The Judaean Priesthood During the Neo-Babylonian and Achaemenid Periods: A Hypothetical Reconstruction,” CBQ 60(1998): 31-36.

${ }^{65}$ Ephraim Stern and Yitzhak Magen, “Archaeological Evidence for the First Stage of the Samaritan Temple on Mt. Gerizim,” IEJ 52 (2002): 55-56.

${ }^{66}$ Additionally, Blenkinsopp suggests that "Casiphia, the place” (כספיא המקום) from which Ezra recruits Levites for temple service (Ezr 8:17) may have been "a cultic establishment of some kind" in Babylonia (Ezra-Nehemiah: A Commentary [Old Testament Library; Philadelphia: Westminster Press, 1988], 165-66).

${ }^{67}$ For example: Saul/Paul of Tarsus was proud of his Benjaminite heritage (Rom 11:1; Phil 3:5), but also self-

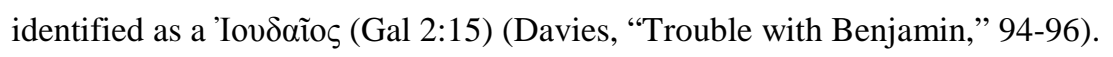




\subsection{BENJAMIN IN THE BIBLE}

The goal of this section is to briefly survey the biblical portrayals of Benjamin, Benjaminites, and Benjaminite regions outside of the DtrH and Chronicles, and assess their significance for intertribal relations in the Persian period.

\subsubsection{Genesis}

The book of Genesis, a mixture of Northern, Southern and Priestly traditions, contains important Benjaminite material, including the aetiological stories of the status of Bethel (Gen 28) and Mizpah (Gen 31:45-54), the birth of Benjamin (Gen 35:16-21), ${ }^{68}$ the interactions of Joseph and his brothers in Egypt (Gen 42-46), and Israel's blessing upon Benjamin (Gen 49:27).

The aetiologies of Bethel (Gen 28) and Mizpah (Gen 31:45-54) bracket the eastern sojournings of Jacob. Both stories include a vow to God and the erection of a pillar or cairn. These aetiologies of key Benjaminite cultic sites are preceded in Genesis by the narrative of the Sacrifice of Isaac (Gen 22), which may itself be a prominent aetiology of Jerusalem's status (Gen 22:2; 2 Chr $3: 1){ }^{69}$ The antiquity of the Benjaminite sites is surpassed by that of Jerusalem.

Genesis 35:16-21 provides explanations both for Benjamin's name and for the location of Rachel's tomb, which became a sacred site. The etymology of "Benjamin" (בן + ימין) could be understood either as "son of the south"-which would make historical and geographic sense from a Northern perspective ${ }^{70}$ —or as "son of the right hand," which is the reading of Genesis 35:18. The latter etymology is the basis for numerous instances of wordplay in the Hebrew Bible concerning left-handed (lit. "right-hand-hindered" אטר יד-ימין) or ambidextrous Benjaminites, "sons of the right hand" (Jdg 3:15; 20:16; 1 Chr 12:2). Perhaps the preference in Genesis 35 for the "right hand" etymology over the "south" etymology is evidence of Judahite influence on the narrative.

Blenkinsopp speculates that the "Rachel's tomb" tradition was taken over by Judahites after the story's revival in the Neo-Babylonian period. The most likely location of Rachel's tomb, he

${ }^{68}$ Daniel E. Fleming observes that Benjamin is "isolated from the other Israelite peoples in key respects, including the separation of its ancestral birth narrative from all the others" (The Legacy of Israel in Judah's Bible: History, Politics, and the Reinscribing of Tradition [New York: Cambridge University Press, 2012], 144-145).

${ }^{69}$ See also Gen 14:18-20: the enigmatic figure of Melchizedek, "priest of אל עליון,", is king of "Salem"perhaps Jerusalem.

70 "If Benjamin is really 'southern' in local terms...it is from an Ephraimite point of view" (Fleming, Legacy of Israel in Judah's Bible, 147). 
maintains, was within Benjaminite territory as evidenced in 1 Samuel 10:2 and Jeremiah 31:15. ${ }^{71}$ The account of Rachel's death in Genesis 35:16-21 places the event between Bethel and Ephrathah, which is glossed as Bethlehem (Gen 35:19, 48:7). The Judean/Judahite scribal tradition, he argues, appropriated the story so as to place this sacred site within Judah's territory: "The takeover of the grave tradition of the great matriarch was one aspect of the process by which Judean-Jerusalemite hegemony was revalidated during the first century of Persian rule."72

There also appears to be Judahite influence on the Joseph Novella (Gen 37-50) as the narrative pertains to Benjamin and intertribal relations. Joseph is usually understood as the main character in this narrative, but a careful reading reveals that Judah's role is also crucial, particularly in relation to Benjamin. ${ }^{73}$ Judah separates himself from his brothers (38:1), learns a valuable lesson in his sojournings (38:26), and later reunites with his brothers (42:3). Judah's character develops from a man who sells a half-brother into slavery (37:26-28) to a man who offers himself as a slave in order to save a half-brother, Benjamin, from slavery (44:18-34) ${ }^{74}$ Jacob releases Benjamin not into Reuben's care but into Judah's (42:36-43:14). Benjamin, like Rachel (31:32-35), is endangered by a rash pronouncement of capital punishment for theft of a holy object (44:9-12). Benjamin's life is endangered by Joseph, his full-brother, but protected by Judah (44:18-34).

One can speculate as to how these traditions might have been read in—or shaped by-the context of intertribal relations in the Persian period. Judahite influence on Genesis 35 incorporates a Benjaminite sacred site into Judahite territory. In the Joseph Novella, Judah in his capacity as protector is more closely associated with Benjamin than is Joseph, indicating a Persian-era Judahite aim to associate Benjamin with Yehud over-against Samaria. ${ }^{75}$

In Jacob's blessings for his sons (Gen 49), Benjamin's blessing is last (v 27), a single verse following a five-verse blessing upon Joseph (vv 22-26) and a four-verse blessing upon Judah (vv 912).

${ }^{71}$ Joseph Blenkinsopp, "Benjamin Traditions Read in the Early Persian Period," in Judah and the Judeans in the Persian Period (ed. Oded Lipschits and Manfred Oeming; Winona Lake, IN: Eisenbrauns, 2006), 631.

72 Blenkinsopp, "Benjamin Traditions," 633.

${ }^{73}$ Gary E. Schnittjer, The Torah Story: An Apprenticeship on the Pentateuch (Grand Rapids: Zondervan, 2006), 163-171.

${ }^{74}$ Mark A. O'Brien, “The Contribution of Judah's Speech, Genesis 44:18-34, to the Characterization of Joseph,” CBQ 59 (1997): 429-47; Richard J. Clifford, “Genesis 38: Its Contribution to the Jacob Story,” CBQ 66 (2004): 519-532.

75 Jean-Louis Ska, Introduction to Reading the Pentateuch (trans. Sr. Pascale Dominique; Winona Lake, IN: Eisenbrauns, 2006), 206-208. Ska suggests: “Judah's 'transformation' is easier to understand if we consider it to be the result of a 'Southern' revision of the earliest account. Judah becomes the instrument of reconciliation in a family wounded by discord. This attitude certainly corresponds to the role played by the region of Judah after the fall of Samaria. Thus, the Joseph story probably originated in the North and was later transferred to the South" (207). 


\subsubsection{Exodus-Deuteronomy}

The next four books of the Pentateuch contain very little in the way of specifically "Benjaminite" material.

The censuses of Numbers 1 and 26 both indicate Judah as the most populous tribe by far (1:26-27; 26:19-22). But in the encampment order/arrangement, Benjamin is grouped with the Josephite tribes to the west of the tent of meeting (Num 2:18-24).

Blenkinsopp suggests that Moses's blessing of Benjamin in Deuteronomy 33:12 is evidence of a Benjaminite sanctuary at Bethel between the first and second Jerusalemite temples. ${ }^{76}$ The blessing pronounces that "the Most High ${ }^{77}$...dwells within his borders," reading כָָּ as "border" as in the Joshua boundary lists (Josh 15,18 ) rather than "shoulder.,"78

\subsubsection{Jeremiah}

Jeremiah is described as a priest from Anathoth (Jer 1:1;29:27), one of the cities within Benjaminite territory allotted to the Levites (Josh 21:18). Benjaminites and the land of Benjamin are featured in several narratives and oracles found in the book of Jeremiah.

Jeremiah prophesies judgment upon Judah and Jerusalem for sin, and urges capitulation to Babylon and acceptance of YHWH's punishment (Jer 21; 25; cf. 29:7). Jeremiah 6:1 begins an oracle of judgment on Jerusalem with a warning: "Flee, sons of Benjamin, from the midst of Jerusalem!' Benjamin's close association with Jerusalem, the prophet warns, will bring disaster. As discussed above, it appears that Benjaminite towns did capitulate to Nebuchadrezzar and thus escaped destruction.

Jeremiah's message of capitulation—not surprisingly—is resisted by the king and the elites of Jerusalem (27:16-22). Jeremiah also meets with resistance in his own land of Benjamin. In Jeremiah 28, Hananiah, a Gibeonite prophet, opposes Jeremiah's capitulationist prophecy by breaking the yoke that Jeremiah had crafted as a picture of Babylonian oppression (27:1-15). Hananiah's prophecy that Babylon's yoke would be broken in two years (28:3) does not come to pass, and Hananiah pays for his false prophecy with his life (28:17).

A more positive prophecy relating to Benjamin is found in Jeremiah 32-33. During the siege of Jerusalem after Zedekiah's rebellion (32:1-5), Jeremiah is commanded by YHWH to purchase a field in Anathoth in anticipation of future restoration (32:6-15). The prophesied restoration of Israel

\footnotetext{
${ }^{76}$ Blenkinsopp, "Benjamin Traditions," 638.

${ }^{77}$ Following the LXX (o $\left.\theta \varepsilon \circ \varsigma\right)$ and the suggestion of the BHS (עליון for עליו ).

${ }^{78}$ Blenkinsopp, "Benjamin Traditions," 634-635.
} 
includes the hill country, the lowland, the Negev, "the land of Benjamin," the environs of Jerusalem, and the cities of Judah (33:13).

\subsubsection{Latter Prophets and Writings}

A handful of references to Benjaminite places and people may be found within the Latter Prophets and the Writings outside the books of Jeremiah, Ezra-Nehemiah and Chronicles. Some references associate Benjamin with either Judah or the Northern tribes (or both). Certain references contain allusions to passages in the Pentateuch or Former Prophets that have been or will be discussed separately. ${ }^{79}$

Hosea 5:1-2 associates Mizpah with Tabor and Shittim, representing the southern and northern borders of Israel, and the Transjordan, respectively. The implication is that Mizpah, like these other towns, has housed illegitimate cultic activity. ${ }^{80}$ Amidst a prophecy of judgment upon Ephraim, Benjamin is warned: "Blow the horn in Gibeah, the trumpet in Ramah; sound the alarm at Beth-aven: 'Behind you, Benjamin!’” These Benjaminite towns would have been in the path of an invasion of Jerusalem from the north, perhaps in the context of the Syro-Ephraimite War ${ }^{81}$ demonstrating that Benjamin (or at least these towns) was at this time associated with Judah.

Both Hosea 9:9 and 10:9 allude to the Rape of Gibeah episode (Jdg 19) in the context of judgment upon sin. Interestingly, the historically Benjaminite city of Gibeah is paired with "Ephraim" (9:8; 10:11) and "Israel" (10:9)—not with Judah. Bethel is likewise implicated in the sins of the king of Israel (10:15; cf. $1 \mathrm{Kgs} 12: 28-13: 34)$. Elsewhere, Bethel is celebrated as the place where YHWH met Jacob (12:4; cf. Gen 28).

Amos likewise mentions Bethel several times in the context of the idolatrous worship of the Northern Kingdom. The Bethel altar is repeatedly denounced (Amos 3:14; 4:4; 5:5-6; 7:10-13).

Isaiah 10:28-34 envisions an invasion of Judah from the north. Along the way, at least two Benjaminite towns provide little resistance: "Gibeah of Saul has fled" (10:29b $\beta)$, and "Give ear, Laishah; answer her, Anathoth!" (10:30b). Only at Jerusalem is the invasion halted: "Yet today he will halt at Nob; he shakes his fist at the mountain of the daughter of Zion, the hill of Jerusalem" (10:32). Isaiah 28:21 mentions Gibeon as a place of YHWH's rage in judgment, with a possible allusion to Joshua 10:10 and the miraculous deliverance at that valley. ${ }^{82}$

\footnotetext{
${ }^{79}$ The Benjaminite content of the book of Esther in relation to Saul is discussed below (\$4.3.2).

${ }^{80}$ Gregory Mobley, "Hosea," in The New Oxford Annotated Bible (NOAB), Michael D. Coogan, ed. (New York: Oxford University Press, 2007), 1284.

${ }^{81}$ Mobley, "Hosea," 1284.

82 Joseph Blenkinsopp, "Isaiah," in The New Oxford Annotated Bible (NOAB), Michael D. Coogan, ed. (New York: Oxford University Press, 2007), 1015-1016.
} 
Obadiah 1:19 mentions Benjamin in a prophetic oracle concerning the judgment of Edom and the restoration of Israel/Judah to the land. The exact identity of the returnees who possess the various territories in association with Benjamin is not clear:

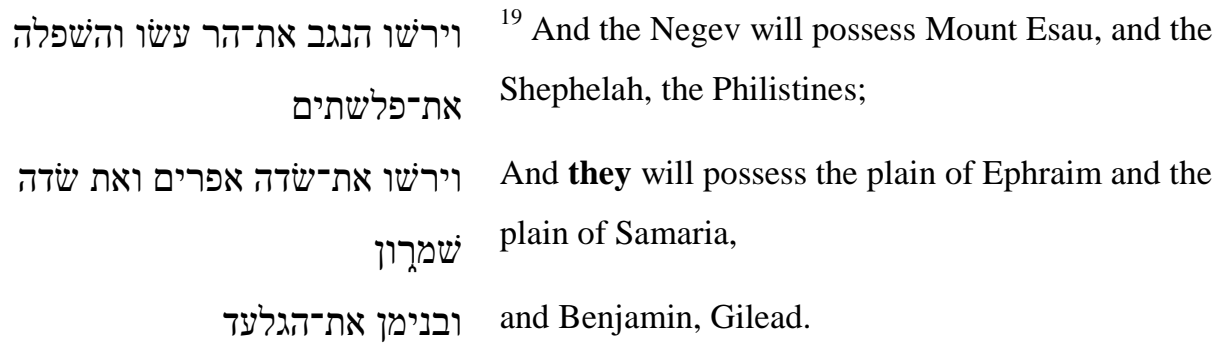

A plainly literal reading of this verse might indicate that the former inhabitants of the Negev and Shephelah-Southern (Judahite) territories—are the ones who are being associated with Benjamin as (returning) dispossessors. The preceding and succeeding verses associate Jacob with Joseph (1:18), and the "the exiles of the sons of Israel" with "the exiles of Jerusalem" (1:20). This oracle appears to envision all of traditional Israel—including Judah, Benjamin and the Northern tribesreturning to Palestine and extending its possession into the neighboring regions.

The superscriptions of five psalms make reference to David's conflict with Saul (Pss 18; 52; 54; 57; 59). Three psalms mention Benjamin or Benjaminites other than Saul. The superscription of Ps 7 sets the psalm in the context of injustice endured by David in the matter of "Cush, a Benjaminite." Psalm 68:27 celebrates YHWH as divine warrior entering into his temple, and places Benjamin at the head of the procession: "There is Benjamin, the youngest, ruling them (רדם), the princes of Judah in their throng; the princes of Zebulun, the princes of Naphtali." In Psalm 80apparently a communal lament for the Northern Kingdom of Israel-the only tribes mentioned by name are "Ephraim, Benjamin and Manasseh" (80:2).

\subsubsection{Summary}

The significance of Benjamin within the biblical corpus cannot be denied. Only the tribes of Judah, Levi and Ephraim are mentioned more frequently than Benjamin in the Hebrew Bible by name. ${ }^{83}$ The texts surveyed reflect the circumstances and attitudes of a wide range of times and places within ancient Israel, and some of the traditions are no doubt older than the texts that contain them. Benjamin and Benjaminites are portrayed in both positive and negative light. Benjamin is associated sometimes with Judah and the south, and sometimes with the Josephite tribes and the Northern Kingdom. This ambiguity is due to Benjamin's relative importance as a border tribe, as

${ }^{83}$ Totals in the English Bible (NRSV), including demonyms, toponyms: Judah, 830; Levi, 365; Ephraim, 183; Benjamin, 181; Manasseh, 128; Reuben, 90;Gad, 86; Dan, 74; Naphtali, 50; Zebulun, 48; Simeon, 47; Asher, 44; Issachar, 43. 
well as the evolving loyalties of Benjaminite towns, regions and families/individuals over the course of Israel's history.

\subsection{SAUL: SURVEY OF RESEARCH ${ }^{84}$}

The most prominent Benjaminite in the Hebrew Bible is Saul, the first king of Israel. One of the most prominent features of the book of Samuel is the conflict between Saul and David, kings associated with the two constituent tribes of what would become the kingdom of Judah and the province of Yehud.

In preparation for a fresh, detailed examination of the portraits of Saul in the books of Samuel-Kings and Chronicles, this section will survey significant literary and theological studies of Saul, with special attention to the authors' socio-historical reconstruction of possible settings for these books (or sections of books).

\subsubsection{Saul's Characterization: A Mere Foil for David?}

The issue of Saul's role in the DtrH relative to David has been an object of significant attention in literary and theological studies of Saul. A related question is whether the Deuteronomist adapted an earlier, more favorable Saul tradition.

Amit observes that the portrait of Saul in the DtrH is considerably more complex and nuanced than the portrait of Saul in Chronicles. ${ }^{85}$ The DtrH presents a balanced picture of Saul through three literary means: the life-story presented with the features of a "tragic hero" story; the hero "shown in conflict with other complex personae," including Samuel and David; and information "given in an ambivalent manner, which enables the reader to see the events in another and complex light, and thus to understand Saul and sometimes even to identify with him." 86 Amit considers these three devices in some detail.

Amit observes that Aristotle's "five stages of tragedy" as outlined in the Poetics are evident in 1 Samuel's story of Saul's life: "fateful error" at Gilgal (1 Sam 13:7-15); the "terrible act" in violating the ban on Amalek (1 Sam 15); the "turnabout" in Samuel's pronouncement (1 Sam 15:28); Saul's “recognition" of his own downfall as David rises (1 Sam 18:8); and finally, Saul's

${ }^{84}$ The following section incorporates material from my previously unpublished paper, "Sleeping Dogs: Benjamin-Judah Relations in the Persian Period and the Chronicler's Portrait of Saul," presented at the Mid-Atlantic Regional meeting of the Society of Biblical Literature in Baltimore, MD, in March 2013. I am grateful to the conference participants for their constructive feedback.

${ }^{85}$ Yairah Amit, "The Delicate Balance in the Image of Saul and Its Place in the Deuteronomistic History," in Saul in Story and Tradition (ed. Carl S. Ehrlich and Marsha C. White; FAT 47; Tübingen: Mohr-Siebeck, 2006), 71-79.

${ }^{86}$ Amit, "The Delicate Balance in the Image of Saul," 71. 
“suffering" leading up to his death (1 Sam 19-31). ${ }^{87}$ This complex portrait of Saul's struggles enables the reader to empathize with him and feel compassion toward him. Indeed, Amit points out that Josephus admired and praised Saul's "justice, valor and wisdom." 88

Next, Amit highlights the complexity of the "protagonists" of 1-2 Samuel with which Saul is contrasted. Samuel's failure to reprimand his sons (1 Sam 8:1-6) is a blemish on his record, demonstrating some concern to retain power and prestige. David defected to Philistia when it was expedient for him (1 Sam 27). "The fact that the other images have their own negative features contributes to the subtle balance. Thus, Saul is not depicted as all bad, and the others are not depicted as all virtuous, but all of them are in shades of gray." 89

Third, Amit brings Samuel's portrait of Saul into contrast with what she considers to be the decidedly "one-sided" portrait of the Chronicler:

The indictment of Saul in the Book of Chronicles contrasts with the delicate balance of his characterization in the Book of Samuel, where the reader can discern the positive sides of the first chosen king, while at the same time understanding why the kingship was taken from him. In other words, Saul may be criticized while feeling sympathy for him. ${ }^{90}$

Amit then considers an apparent paradox: the Deuteronomist, whose writings are famously characterized by "unequivocal right and wrong, things that are allowed and things that are forbidden," still carefully depicted the moral complexity of such figures as David and Saul. ${ }^{91}$ She argues that "where the Deuteronomistic author-editor could not ignore the fact that the events reflected good and evil mingled together, he chose to separate the times when the king was faithful to God from those when he strayed from the righteous path." 92

Amit's observations about the differences between the DtrH and Chronicles certainly have merit - though she perhaps overstates the negativity of the Chronicler's treatment of Saul. Could one argue conversely that the Chronicler has chosen to abbreviate significantly the anti-Saul polemic of the DtrH, and that the Chronicler's portrayal of Saul is more irenic, designed to create consensus between Judah and Benjamin?

\footnotetext{
${ }^{87}$ Amit, "The Delicate Balance in the Image of Saul," 72-73.

${ }^{88}$ Amit, "The Delicate Balance in the Image of Saul," 73-74.

${ }^{89}$ Amit, "The Delicate Balance in the Image of Saul," 75.

${ }^{90}$ Amit, "The Delicate Balance in the Image of Saul," 76.

${ }^{91}$ Amit, "The Delicate Balance in the Image of Saul," 76.

${ }^{92}$ Amit, "The Delicate Balance in the Image of Saul," 77.
} 
Amit prefers the DtrH's complexity to the Chronicler's brevity and apparent partisanship against Saul—she refers to the DtrH's presentation of Saul and David as "superb literature!"93 Saul, David and Solomon are flatter characters in Chronicles than in Samuel-Kings. Yet perhaps the Chronicler chooses not to focus on Saul in order to avoid reopening old wounds resulting from David-Saul (Judah-Benjamin) feuds.

One also wonders whether Amit's assertion of the DtrH's separation of the faithful and evil actions of each king upholds the standard paradigm of the Deuteronomist as rigidly, unequivocally focused on the Law - or whether her observations subtly mitigate that understanding of the Deuteronomist's rigidity and "black-and-white" perspective.

McKenzie's view of the portrait of Saul in the DtrH is encapsulated in the designation of Saul as nagid (1 Sam 9:16; 10:1), or "designated [military] leader." Saul serves as "a transitional figure mediating between the judges and the monarchy. The spirit of YHWH comes upon him as upon a judge; and he is commissioned to military action (10:6-7). Ultimately, though, this nagid proves unacceptable as king." 94 The DtrH acknowledges Saul's early military successes as a judge/prince/nagid, but presents Saul as too morally compromised to be considered a king. "As "As king, Saul can do almost nothing right." ${ }^{, 96}$ Even when he zealously killed Canaanites-supposedly in obedience to YHWH's conquest mandate (cf. Deut 7)— he in fact did wrong by killing the Gibeonites with whom Israel had made a covenant (2 Sam 21:1-14). ${ }^{97}$

David, by contrast, is fit to be king, "a man after [YHWH]'s heart" (1 Sam 13:14). David's military success quickly exceeds Saul's, but David's moral success is fronted as well. McKenzie concludes that Saul in the DtrH is "more pitiful than villainous"- - he was fated to fail from the beginning. ${ }^{98}$ Following Van Seters, ${ }^{99}$ McKenzie holds that Saul is merely a foil for David in the DtrH. ${ }^{100}$

Mobley presumes that the Saul narrative in the book of Samuel is drawn from an originally "heroic profile" of Saul that is "now obscured in accounts edited by historians partial to his Iron

${ }^{93}$ Amit, "The Delicate Balance in the Image of Saul," 78 (exclamation original).

${ }^{94}$ Steven L. McKenzie, "Saul in the Deuteronomistic History," in Saul in Story and Tradition (ed. Carl S. Ehrlich and Marsha C. White; FAT 47; Tübingen: Mohr-Siebeck, 2006), 61.

${ }^{95}$ McKenzie, "Saul in the Deuteronomistic History," 62, 68-69.

${ }^{96}$ McKenzie, "Saul in the Deuteronomistic History," 62.

${ }^{97}$ McKenzie, "Saul in the Deuteronomistic History," 67.

${ }^{98}$ McKenzie, "Saul in the Deuteronomistic History," 68.

${ }^{99}$ John Van Seters, In Search of History: Historiography in the Ancient World and the Origins of Biblical History (New Haven, 1983), 263.

${ }^{100}$ McKenzie, "Saul in the Deuteronomistic History," 69. 
Age rival: David ben Jesse." ${ }^{101}$ He proposes to "isolate features in stories about Saul in 1 Samuel 914 that are corroborated, inversely, by details in 1 Samuel 15-31 which offer explicit or implicit contrasts between Saul and David."102

Mobley briefly sketches six "negatives" of Saul's heroic character-negative, "in its photographic sense of a reverse impression" 103 — that are obscured or overshadowed by the character of David in 1 Samuel. First, Saul is presented as an impressive physical specimen, exceptionally tall and handsome (1 Sam 9:2-3; 10:23), but Samuel's choice of David over his brother Eliab is construed as a divine discounting of the importance of physical appearance. ${ }^{104}$

Second, "Saul exhibits the martial rage, or battle fury, suitable to a great warrior" (1 Sam 914). ${ }^{105}$ Yet Saul's "inspiration" from YHWH departs to David (1 Sam 16:13), and from this point on in the story, "Saul's martial rage, often a marker of supreme battlefield performance, turns into a kind of madness, as he inappropriately erupts in domestic contexts (1 Sam 18:10-11; 19:9-10; 20:30-33), and turns against, not enemies, but YHWH's anointed." ${ }^{\text {"106 }}$ Third, Saul performed heroically and brilliantly in battle, but his prowess was acknowledged in song only as a foil to David's (1 Sam 18:7-8). ${ }^{107}$

Fourth, Saul appears to have been known for his signature weapons and armor, especially his spear (1 Sam 13:22; 18:10; 19:9; 20:33; 22:6; 26:6-22). Yet Saul never uses his spear in battle; he hurls it at Jonathan and at David. In the face of David's taunt to Goliath ("YHWH does not deliver by sword or by spear"), "Saul's hard-earned tokens of martial status have become impediments and superfluities." 108 Fifth, Saul's "mighty men" are drawn from Gibeah, the site of the outrage in Judges 19 (though Mobley admits: "Here, admittedly, I am moving further afield in the Deuteronomistic History"). ${ }^{109}$

Finally, Mobley argues that a comparison between the two stories behind the saying "Is Saul also among the prophets?" reveals the heroic component of the story he regards as original (1 Sam 10). Mobley follows Edelman's suggestion that in 1 Samuel 9:27-10:14 "posed as a member of a prophetic guild in order to gain access to a Philistine prefect for the purpose of assassinating

${ }^{101}$ Gregory Mobley, "Glimpses of the Heroic Saul," in Saul in Story and Tradition (ed. Carl S. Ehrlich and Marsha C. White; FAT 47; Tübingen: Mohr-Siebeck, 2006), 80.

\footnotetext{
${ }^{102}$ Mobley, "Glimpses of the Heroic Saul," 81.

${ }^{103}$ Mobley, "Glimpses of the Heroic Saul," 81.

${ }^{104}$ Mobley, "Glimpses of the Heroic Saul," 81.

105 Mobley, "Glimpses of the Heroic Saul," 82.

${ }^{106}$ Mobley, "Glimpses of the Heroic Saul," 82.

${ }^{107}$ Mobley, "Glimpses of the Heroic Saul," 82-83.

${ }^{108}$ Mobley, "Glimpses of the Heroic Saul," 83-84.

${ }^{109}$ Mobley, "Glimpses of the Heroic Saul," 84.
} 
him." ${ }^{110}$ In this regard Saul is not unlike the crafty Benjaminite judge, Ehud, who used a "word from the gods" to gain access to assassinate Eglon ( $\operatorname{Jg} 3$ ). But the pro-David etymology of the saying (1 Sam 19:18-24) turns Saul into "a self-lacerating, babbling, whirling exhibitionist."111

Mobley's character analysis supports White's thesis of an original, coherent story of Saul's rise, ${ }^{112}$ as well as Amit's view of the DtrH's presentation of Saul as a tragic hero. ${ }^{113}$

White mentions a hypothetical "northern prophetic history that is suspicious of kingship and lies midway between the sources and the Deuteronomistic history" in 1 Samuel 1-14. This view is offered by Birch, McCarter, Campbell and O'Brien, but White herself and McKenzie disagree. ${ }^{114}$ White holds that 1 Samuel 1-14 "exhibits an uncomplicated and straightforward history of composition....It is a complete and coherent History of Saul's Rise, meant to legitimate his unprecedented assumption of the throne and assassination of the Elide priests."115

It has been widely noted that the aetiological story of Samuel's name appears to fit the etymology of Saul's name instead (use of שאל roots in 1 Sam 1:1-28; 2:11a). ${ }^{116}$ Against the view that the Samuel birth narrative was originally Saul's narrative that was later transferred to the prophet-priest who anointed David, ${ }^{117}$ White argues that 1 Samuel 1-3 is a single, coherent story of the rise of Samuel designed to legitimate his anointing of Saul. ${ }^{118}$ She notes that the Samuel birth story (1 Sam 1) contains seven occurrences of the שאל root, as well as seven occurrences of נתן*, which is the root of Jonathan's name. ${ }^{119}$ She suggests:

${ }^{110}$ Mobley, "Glimpses of the Heroic Saul," 85. See Diana Edelman, "Saul," in Anchor Bible Dictionary, vol. 5 (ed. David Noel Freedman; New York: Doubleday Publishing, 1992), 993.

${ }^{111}$ Mobley, "Glimpses of the Heroic Saul," 86.

${ }^{112}$ Marsha C. White, "Saul and Jonathan in 1 Samuel 1 and 14," in Saul in Story and Tradition (ed. Carl S. Ehrlich and Marsha C. White; FAT 47; Tübingen: Mohr-Siebeck, 2006), 119-138.

${ }^{113}$ Amit, "The Delicate Balance in the Image of Saul," 72-73.

${ }^{114}$ White, "Saul and Jonathan in 1 Samuel 1 and 14," 119. See Bruce C. Birch, The Rise of the Israelite Monarchy: The Growth and Development of I Samuel 7-15 (SBLDS 27; Missoula, Mont.: Scholars Press, 1976), 1-7, 131, passim; P. Kyle McCarter, Jr., I Samuel (Anchor Bible Commentary; Garden City, N.Y.: Doubleday, 1980), 13-19; Antony F. Campbell, Of Prophets and Kings: A Late Ninth Century Document (1 Samuel 1 - 2 Kings 10) (CBQMS 17; Washington: Catholic Biblical Association of America, 1986), 14-16; Mark A. O’Brien, The Deuteronomistic History Hypothesis: A Reassessment (Göttingen: Vandenhoeck \& Ruprecht, 1989), 25-26.

\footnotetext{
${ }^{115}$ White, "Saul and Jonathan in 1 Samuel 1 and 14," 120.

${ }^{116}$ White, "Saul and Jonathan in 1 Samuel 1 and 14," 120-121.

${ }^{117}$ White, "Saul and Jonathan in 1 Samuel 1 and 14," 121.

${ }^{118}$ White, "Saul and Jonathan in 1 Samuel 1 and 14," 126.

${ }^{119}$ White, "Saul and Jonathan in 1 Samuel 1 and 14," 124-126.
} 


\begin{abstract}
Samuel's birth narrative does not merely allude to Saul and Jonathan; it is actually all about Saul and Jonathan, with the concluding keyword stress on Saul. If I am correct that the birth narrative is the first scene of an apologetic history designed to establish Saul's kingship, then the reason for the telling of Samuel's birth in terms of Saul's and Jonathan's names becomes clear. Although Samuel dominates the beginning of the history (1 Sam 1:1-4:1a), his preeminence there is solely for the sake of credentialing him as YHWH's intermediary. ${ }^{120}$
\end{abstract}

Furthermore, she argues, "Samuel's presence in Saul's history is not for his own sake or for the sake of advancing prophetic authority in general, but for the specific political purpose of installing a Saulide dynasty.",121

Next, White turns her attention to the conclusion of what she theorizes is the original proSaul redaction of 1 Samuel (chapters 1-14). ${ }^{122}$ She notes the connections between Hannah's vow and devoting of her firstborn to Saul's "rash" vow and near sacrificing of his firstborn, Jonathan (1 Sam 14:23b-30, 36-45). ${ }^{123}$ White questions the rashness of Saul's vow, arguing that this was a later negative interpretation after the Davidic redaction massaged these stories into a history of David's rise. Rather, she claims, Saul's vow is on par with Hannah's, and his willingness to put Jonathan to death demonstrates his piety on par with that of Joshua in the matter of Achan (Josh 7-8). ${ }^{124}$ She further compares Saul's faith to that of Abraham: "When forced to choose between his son's life and the establishment of his dynasty on the one hand and fidelity to God on the other, like Abraham Saul does not hesitate to choose rightly."125

In summary, most scholars agree that the DtrH in its received form presents Saul in a much more negative light than it does David. Scholars disagree, however, on several key points: 1) whether the presentation of Saul is entirely negative; 2) whether an original, more positive Saul narrative stands behind the received form of the text; and 3) how much of that original Saul narrative can be discerned in the received text. Against the first point, McKenzie argues that the Deuteronomist's Saul can do nothing right as king, but serves merely as a foil for David. White and Mobley argue in favor of the second point, positing that the pro-Saul rhetoric forms an original coherent story of Saul's rise and pious rule. Amit, focusing on the received text, balances the proSaul and anti-Saul material and argues that the Deuteronomist presents Saul as a sympathetic but tragic hero-in contrast to the Chronicler's one-sided portrayal.

${ }^{120}$ White, "Saul and Jonathan in 1 Samuel 1 and 14," 126-127.

${ }^{121}$ White, "Saul and Jonathan in 1 Samuel 1 and 14," 127.

${ }^{122}$ Cf. V. Philips Long, The Reign and Rejection of King Saul: A Case for Literary and Theological Coherence (Atlanta: Scholars Press, 1989).

${ }^{123}$ White, "Saul and Jonathan in 1 Samuel 1 and 14," 128.

${ }^{124}$ White, "Saul and Jonathan in 1 Samuel 1 and 14," 128-135.

${ }^{125}$ White, "Saul and Jonathan in 1 Samuel 1 and 14," 135. 
Each of these perspectives on Saul has merit, and favoring one does not preclude the others. It is apparent that, even if one can discern in the DtrH elements that could have originally been considered positive or meritorious for Saul, the text in its current form has taken those positives and turned many of them into negatives (in both senses of the term) that contrast with David. Amit's focus on the complex character of Saul perhaps does the greatest justice to the text in its final form.

\subsubsection{A Saul Polemic?}

What might have been the historical context or contexts in which a hypothetical original Saul narrative and the extant Deuteronomistic revision of that narrative were written and compiled? Various exilic and postexilic situations have been proposed.

Edelman argues that the book of Samuel appears to reflect two socio-historical contexts. First, Samuel, as a written work, would have been originally directed primarily toward "the aristocracy and court in whatever period it was written," whether or not the book found a wider audience early in its existence through public readings. ${ }^{126}$ The message to the elite audience was designed to "[legitimize] claims of the Davidic monarchy to rule rather than the Saulide monarchy." 127 By contrast, the moral ambiguity of the presentations of both Saul and David appears to endorse "the elimination of kingship in favor of YHWH's direct rule over his people,"128 a message directed to a broad audience at a later time.

In discussing a possible socio-historical setting for a pro-David, anti-Saul polemic, Edelman notes, "Any setting should explain why the rivalry is between the Davidic and the Saulide dynasties, and not, for example, the Omrides or the line of the last Israelite king, Hoshea."129 This would undoubtedly be a Judah (Southern Kingdom) context or a Babylonian- or Persian-era Yehud context, since Benjaminites (with potential loyalty to Saul) were associated with Judah and Yehud. The Davidic covenant (2 Sam 7) contrasts the two kings: David's line would never be cut off for disobedience as Saul's was.

The covenantal theme seems designed to counter an argument that YHWH inserted David into the Saulide line as a temporary interloper but did not intend his descendants to rule after him in place of

${ }^{126}$ Diana V. Edelman, “Did Saulide-Davidic Rivalry Resurface in Early Persian Yehud?” in The Land That I Will Show You: Essays on the History and Archaeology of the Ancient Near East in Honour of J. Maxwell Miller (ed. J. Andrew Dearman and M. Patrick Graham; Sheffield: Sheffield Academic Press, 2001), 70.

${ }^{127}$ Edelman, "Saulide-Davidic Rivalry,” 71.

${ }^{128}$ Edelman, "Saulide-Davidic Rivalry," 70.

${ }^{129}$ Edelman, "Saulide-Davidic Rivalry," 71. 
Saul's descendants. Thus, it seems to imply that some group in the community is asserting the right of Saulides to rule over against Davidides. ${ }^{130}$

Edelman posits two plausible social settings for such a message: the tenth century BCE "in the aftermath of either Saul or Eshbaal's death," or the last third of the sixth century BCE when the returning golah community would have favored a revival of the Davidide monarchy. She rejects the tenth-century context because of "several historical inaccuracies" which would have rendered the message unacceptable to an audience of David's contemporaries familiar with recent events. ${ }^{131}$

A late sixth-century context presents another possible setting for a Davidic-Saulide rivalry that would allow adequate time to elapse for the historical inaccuracies to enter the text (either intentionally or unintentionally):

\begin{abstract}
Those living in the villages that did not go into exile in $586 \mathrm{BCE}$, located primarily in the territory of Benjamin, were included within the borders of the Persian province of Yehud and would likely have favored the appointment of a descendant of the Saulide throne to be the new governor and puppet king of Yehud. Saul was of Benjaminite origin, so interest in the re-establishment of his dynasty in particular (as opposed to a Davidide) would have been strong. Since they were descendants of the court elite of Jerusalem who went into exile in 598 and 586 BCE, members of the golah community, on the other hand, would have favored the re-establishment of a Davidic descendant to power. ${ }^{132}$
\end{abstract}

Edelman suggests three sixth-century scenarios that could have been the impetus for the pro-David, anti-Saul editing of the book of Samuel. In each of these scenarios, Samuel is considered to be directed toward the Persian court as a primary audience for its pro-David message. First, if Sheshbazzar were of Davidic ancestry (Ezr-Neh is silent on this point), Samuel's message might have been aimed at the Persian court by the pro-David golah faction: "The narrative would have functioned as a justification to the new Persian overlords that asserted the historical primacy of the Davidic house over the Saulide house, thus maintaining Sheshbazzar in power." ${ }^{133}$ Second, if Sheshbazzar were not of Davidic ancestry, the golah faction might have intended the book of Samuel as anti-Sheshbazzar rhetoric directed toward the Persian court, with the goal of replacing Sheshbazzar with a royal descendent. In both of these scenarios, one might imagine that the Benjaminite she'erit elites would have submitted a pro-Saul version of the story to counter the golah version, but no such version of the story has survived. ${ }^{134}$ In a third sixth-century scenario, the

\footnotetext{
${ }^{130}$ Edelman, "Saulide-Davidic Rivalry," 72.

${ }^{131}$ Edelman, "Saulide-Davidic Rivalry," 72-73.

${ }^{132}$ Edelman, "Saulide-Davidic Rivalry," 73.

${ }^{133}$ Edelman, "Saulide-Davidic Rivalry," 74.

${ }^{134}$ Edelman, "Saulide-Davidic Rivalry," 74-75.
} 
book of Samuel could have been pro-Zerubbabel rhetoric to legitimize this apparently Davidide ${ }^{135}$ governor in the face of "dissatisfaction among the Benjaminite sector, who felt that a Saulide descendant had as legitimate a claim to leadership as a Davidic descendant, if not more so."136

Edelman goes on to consider the geographical manifestation of such a Judah-Benjamin rivalry that would have given rise to the book of Samuel in the late sixth century. The golah community would obviously have favored Jerusalem as a cultic and administrative center. The Benjaminite community would have favored a site such as Gibeon, which_Edelman argues_-was likely Saul's capital, a fact that the editors of Samuel downplayed. ${ }^{137}$ Yet 1 Chronicles 8-9 connects a Benjaminite community living in Jerusalem in the post-exile by ancestry to the town of Gibeon, "[showing] that some group maintained interest in the genealogy of the Saulide house down to the post-exilic community, and both genealogies link the Saulides to the town of Gibeon." 138

Edelman considers other possible socio-historical settings for the resurfacing of the SaulideDavidic rivalry in Samuel. One suggestion is the time of Josiah, who sought to expand the borders of the Southern Kingdom northward to include more Benjaminite towns and southern Ephraim after the Assyrian conquest of the Northern Kingdom. Edelman argues that a pro-David, anti-Saul message in the book of Samuel might not have resonated with the inhabitants of these towns, who were "newcomers resettled by the Assyrians"- but she concedes that the message of David as rightful king over South and North together might have resonated with the population of the Southern Kingdom in support of Josiah's campaign. ${ }^{139}$ After the Assyrian conquest of the Northern Kingdom, some northerners fled as refugees to Judah — this could also have been the impetus for a pro-David message such as Samuel's.

It is difficult to accept completely Edelman's notion that the primary audience of Samuel was the Persian court. This may have been a secondary audience, but it is likely that the primary audience would have been the elites of Yehud (Judahite and Benjaminite). If Edelman's thesis concerning the DtrH is applied more generally to a comparison with Chronicles, one can view

${ }^{135}$ Edelman notes: "I Chron. 3.19 names Shealtiel as the son of Jeconiah, but then proceeds to make Zerubbabel the son of Pedaiah, Shealtiel's brother, rather than Shealtiel himself. Nevertheless, it assigns him Davidic ancestry in either case, even if one considers the Zerubbabel, son of Pedaiah, to be a different person. In addition, Hag. 2.20-23 states that YHWH Sebaot was soon going to make Zerubbabel, his chosen one and servant, as his signet ring after overthrowing the strength of the nations and destroying their armies. Jeremiah 22.24 describes Jeconiah as the signet ring on YHWH's right hand, demonstrating the use of this expression for a member of the Davidic royal line. Thus, it is highly probable that Zerubbabel was of Davidic ancestry” (“Saulide-Davidic Rivalry," 75-76).

\footnotetext{
${ }^{136}$ Edelman, "Saulide-Davidic Rivalry," 76.

${ }^{137}$ Edelman, "Saulide-Davidic Rivalry," 77-83.

${ }^{138}$ Edelman, "Saulide-Davidic Rivalry," 77-78.

${ }^{139}$ Edelman, "Saulide-Davidic Rivalry," 86-87.
} 
Chronicles as more of a consensus document that downplays the Judah-Benjamin (David-Saul) tensions of the past (as documented in Samuel) in favor of a unifying vision of "all Israel.", 140

Amit, carrying Edelman's question further along into the history of this period, asks whether the Saul polemic revived in the Persian period, and if so, was the polemic "purely literary or resting on historical roots"? ${ }^{141}$ If one accepts a late Babylonian-era or early Persian-era date for Judges and 1 Samuel, what might be the motivation for the inclusion of an anti-Saul polemic — "in other words, what did the Persian Period have to do with Saul? Even if we regard Saul as the archetype of the kings of the Northern Kingdom or an embodiment of the tribe of Benjamin, the question remains: What did the Northern kings or the tribe of Benjamin have to do with the Persian Period?"142 Amit theorizes that three Saul-related stories_-Judges-Samuel in the early Persian period, ${ }^{143}$ and 1 Chronicles 10 and Esther in the late Persian period-reflect changing attitudes toward the possibility of a revived Davidide monarchy.

First, the Judges-Samuel polemic was put forth by "supporters of the Davidic dynasty, because of their opposition to new currents that referred to the Benjaminite option, the House of Saul." She considers this polemic to be "implied," arguing that the pro-David party either "hesitated to favor openly the scions of their favored but disappointing dynasty, 'the fallen booth of David' (Amos 9:11)," or "believed that this technique was a more effective way of changing people's attitudes, since it would not provoke an immediate and obvious resistance to a known figure."144

Second, Chronicles reflects a later "open and unambiguous" anti-Saul polemic. Amit argues that the Chronicler goes out of his way to present Saul in a negative light, even when he could have avoided doing so. 1 Chronicles 10 interprets 1 Samuel 31 in such a way as to depict "God's punishment on a leader who strayed" by consulting a medium; yet according to 1 Samuel 28:6, Saul only sought a medium after God refused to answer him through the urim or the prophets. ${ }^{145}$ "The Chronicler was so keen to defame Saul, that he was willing to deviate from and distort his own

${ }^{140}$ See David A. Glatt-Gilad, "Chronicles as Consensus Literature,” in What Was Authoritative for Chronicles? (ed. Ehud Ben Zvi and Diana Edelman; Winona Lake, IN: Eisenbrauns, 2011), 67-75.

${ }^{141}$ Yairah Amit, "The Saul Polemic in the Persian Period," in Judah and the Judeans in the Persian Period (ed. Oded Lipschits and Manfred Oeming; Winona Lake, IN: Eisenbrauns, 2006), 647.

142 Amit, "Saul Polemic," 648.

${ }^{143}$ Amit observes several connections between the narrative of the rape at Gibeah and its consequences (Jdg 19-21) and the stories of Saul: the conflict between a Judah-led coalition and Benjaminite Gibeah; the reference to Jabesh-gilead (Jdg 21:1-15; 1 Sam 31:11-13; 1 Chr 10:11-12); and "the spreading of information by means of a dismembered body" (Jdg 19:29; 1 Sam11:7; 1 Chr 10:8-10) (“Saul Polemic,” 648). For Amit, Jdg 19-21 “openly attacks the behavior of the tribe of Benjamin and especially of its town Gibeah, and by inference, covertly also Saul” ("Saul Polemic," 652).

\footnotetext{
${ }^{144}$ Amit, "Saul Polemic," 657-658.

145 Amit, "Saul Polemic," 649.
} 
sources." ${ }^{146}$ Furthermore, the Chronicler diminishes the valor of the men of Jabesh-gilead who rescued Saul's body (1 Sam 31:11-13), "reducing the brave action of [these] men...to an ordinary one....The devaluation of the heroism of the men of Jabesh-gilead eliminates the quality of solidarity, sacrifice and valor of Saul's loyal troops and their total commitment to their king."147

Third, Amit argues that by means of clues-mention of the house of Kish, mention of Haman the Agagite- “the book of Esther rehabilitates the descendants of Saul: Esther and Mordecai are virtuous; the unfinished business with Amalek is concluded; and Israel did not lay hands on the spoil." ${ }^{148}$ She suggests a late Persian context for such a rehabilitation:

The pro-Saul polemic went underground and expressed itself in a covert way in the book of Esther. This reversal shows that the problem of leadership had not gone away. The need to justify support for the Davidic dynasty, which had disappeared after Zerubabel [sic], and the need to find alternatives to the House of David, continued to preoccupy biblical literature during the Persian Period. ${ }^{149}$

Edelman and Amit are in agreement that the Deuteronomist's portrait of Saul mirrors some sort of conflict between the descendants of these two figures during the Babylonian or early Persian periods. The question remains, then, whether the Chronicler's presentation of these two figures might reflect a different stage of this important intertribal relationship. How do these two "snapshots" of Benjamin-Judah relations differ, and what do they tell us about the authors' contexts? What would have been at stake in the Chronicler's adaptation of Saul and David material from Samuel?

Amit suggests that the Chronicler's "sharpened polemic against the House of Saul" might have been a response to a rivalry with Benjaminite leadership at Mizpah. It remains an open question at this point in our study whether the Chronicler's portrait of Saul is properly understood as "polemical" - it will be argued that the Chronicler's minimalistic portrait of Saul points to a conciliatory attitude toward Benjamin. Edelman argues that while the Deuteronomist's presentation of these two figures is motivated by a struggle between the two houses in the early Persian period, the Chronicler's limited portrait of Saul is related not to a revived royal rivalry but to the legitimacy of Jerusalem as a cultic center over-against Gibeon. ${ }^{150}$ Edelman's observation seems to come closer to the mark: the royal houses themselves are no longer in play in the late Persian period, but cultic centers were.

\footnotetext{
146 Amit, "Saul Polemic," 649.

${ }^{147}$ Amit, "Saul Polemic," 650.

${ }^{148}$ Amit, "Saul Polemic," 654.

149 Amit, "Saul Polemic," 658.

${ }^{150}$ Edelman, "Saulide-Davidic Rivalry," 78-81.
} 


\subsubsection{Saul in the Persian Imperial Context?}

Jonker suggests that the differences between the portrayals of Saul in Samuel and Chronicles offer insight into the Chronicler's Persian imperial context. ${ }^{151}$ Jonker brings both possible factors previously considered-leadership and cultic location-into his interpretation of the Saul narrative in Chronicles, but adds an important dimension: self-identity in Yehud in the context of the Persian Empire. Chronicles reflects a stage in the process of Yehudite selfidentification, not within a single socio-historical context but within multiple contexts-imperial, regional, ethnic, and cultic. ${ }^{152}$ Reflecting on the evidence of this process in Chronicles, Jonker writes:

It is important to emphasise that these levels never functioned in isolation. The inhabitants of Yehud, and particularly the literati who were responsible for the writing of another historiography, the books of Chronicles, were exposed to all these contexts, and were active participants in all of them. ${ }^{153}$

Why does Saul receive so little attention in Chronicles compared to the DtrH, or conversely, why did the Chronicler pay attention to Saul at all? Knoppers and Jonker propose that the Persian imperial setting of Yehud offers a plausible answer.

Knoppers highlights three sorts of approaches to the role of Saul in the Chronicler's narrative: those that consider Saul as a mere foil for David (Kittel, von Rad, Rudolph); those that emphasize continuity/connection between the Saul narratives in Samuel and Chronicles (Zalewski); and those that consider 1 Chronicles 10 to be strongly tied to the David narratives as an introduction (Mosis, Ackroyd, Japhet). ${ }^{154}$

Knoppers synthesizes these approaches and argues that the Chronicler attempted to strike a delicate balance: "Given the prominence of the tribe of Benjamin in the Chronicler's own day, a prominence the author affirms [in 1 Chr 8:1-9:1], Samuel's stories about Benjaminite Saul's demise

${ }^{151}$ Louis C. Jonker, "Revisiting the Saul Narrative in Chronicles: Interacting with the Persian Imperial Context?" OTE 23 (2010): 283-305.

${ }^{152}$ Louis C. Jonker, "Engaging with Different Contexts: A Survey of the Various Levels of Identity Negotiation in Chronicles," in Texts, Contexts and Readings in Postexilic Literature (ed. Louis C. Jonker; Tübingen: Mohr-Siebeck, 2011), 63, 74, 91.

153 Jonker, "Engaging with Different Contexts," 73-74.

${ }^{154}$ Gary N. Knoppers, "Israel's First King and 'the Kingdom of YHWH in the hands of the sons of David': The Place of the Saulide Monarchy in the Chronicler's Historiography," in Saul in Story and Tradition (ed. Carl S. Ehrlich and Marsha C. White; FAT 47; Tübingen: Mohr-Siebeck, 2006), 189-191; Knoppers, 1 Chronicles 10-29 (Anchor Bible Commentary; New York: Doubleday, 2004), 526-531. 
and Judahite David's rise were likely sensitive issues." ${ }^{155}$ Knoppers proposes that the Chronicler's Saul, rather than being a rival of David, was "a one-time monarch, whose reign turned out to be such a colossal failure that it justified the deity's decision to execute him and turn the kingdom over to an entirely new regime." 156 Thus, the Chronicler "[omitted] all of the stories of David's relationships with Saul, Jonathan, and the members of Saul's house," thus dissociating David from Saul. ${ }^{157}$ By prefacing the narrative of Saul's demise with the genealogy of Saul's clan traced to the postexile (9:35-44), the Chronicler exonerates David of any wrongdoing toward the tribe of Benjamin and isolates the cloud of suspicion over Saul and his family, rather than on Benjamin as a whole. ${ }^{158}$ Only Saul's faithfulness to YHWH is tarnished-Benjamin, Jonathan and David go untainted.

In the context of Persian Yehud, Benjaminites would have been an important target audience for the Chronicler's "all Israel” message. Knoppers observes that the Deuteronomist's accounts of Saul "would provide Benjaminite readers with plenty of ammunition to claim that their most famous ancestor and his house were treated poorly by Judah's hero." ${ }^{159}$ The Chronicler hoped to avoid this conflict by dissociating the two houses and focusing all the criticism on Saul himself, rather than on Benjamin as a whole.

Jonker broadens Knoppers' synthesis on three levels:

Firstly, the Benjaminite link of Jerusalem and the Second Temple can be integrated into his discussion of the prominence of the tribe of Benjamin. Secondly, the relationship between the themes of monarchy and temple can be further developed, but should also be brought into relation to the theme of rest/peace which is so prominent in Chronicles. And thirdly, the international backdrop of Persian royal ideology should also be taken into account in the interpretation of the first two aspects mentioned here. ${ }^{160}$

${ }^{155}$ Knoppers, 1 Chronicles 10-29, 528.

156 Knoppers, “Israel’s First King,” 209.

${ }^{157}$ Knoppers, 1 Chronicles 10-29, 530.

158 “The Chronicler settles the matter of David having any chance to profit personally from his father-in-law's ruin historically by showing that the Jeielite lineage continued well beyond the United Monarchy. In this context, the author can freely acknowledge that the tribe of Benjamin furnished Israel with its first king. The Chronicler can also stress the contributions that the Benjaminites made to the establishment of David's kingdom (1 Chr 11:31; 12:2, 17-19, 30; 27:12, 21). The lineage and tribe of Israel's first monarch are given their due" (Knoppers, 1 Chronicles 10-29, 530).

${ }^{159}$ Knoppers, "Israel's First King,” 209.

${ }^{160}$ Jonker, "Revisiting the Saul Narrative," 296-297. 
Jonker suggests that the Chronicler's Persian royal ideology affected his portrayals of Saul and David, "an ideology that stressed the reciprocity of royal care and loyalty of the subjects." ${ }^{161}$ The Chronicler was a staunch supporter of Judah and the Davidic house, but he sought Benjaminite support for a cult centered near Benjaminite territory. The Chronicler believed that seeking YHWH and supporting YHWH's chosen king would lead to the desired peace for Yehud, symbolized by Solomon's reign. The Chronicler's views of Judah and Benjamin, combined with his theology and royal ideals, are reflected in his portrayals of Israel's kings—including Saul. The Chronicler focused on David's public "ministries" that had ongoing religious and political significance for the community, rather than on David, the man. The Chronicler's royal ideal was a king who brings peace, is penitent, and supports the temple cult. Saul's career, in the Chronicler's estimation, had not furthered the administrative or cultic organization of Israel, and was therefore worthy of no more attention than that given to one of the wicked kings of Judah. Nevertheless, Saul is included as an important link between the tribal period and the "real" monarchy.

Jonker's approach, building on Knoppers's synthesis, offers a rich interpretation of the Saul narrative that takes account of the multi-dimensional context of the Chronicler and his audience. This interpretation of Saul in Chronicles-along with the points argued by Amit and Edelmanraises the much broader question of the portrait of Benjamin in Chronicles: what is at stake in the Chronicler's day, and what is his message for Benjamin?

\subsection{CONCLUSIONS}

The first section of this chapter boldly equated the quest for Benjaminite history with the quest for Israelite history. This assertion has been defended by a demonstration of the centrality of the Benjaminite region to the history of Palestine and the prominence of Benjamin and Benjaminite figures in the Hebrew Bible.

The following sections examine the references within the DtrH and Chronicles to Benjamin and Benjaminites. The DtrH—as we have seen through references to the books of Joshua and Judges and the discussion of the Saul narrative_contains a great deal of Benjamin material. If, as Jonker has observed, "an overwhelming number of occurrences of Benjaminite terminology in Chronicles belong to the writer's Sondergut," ${ }^{\prime 62}$ two points are evident: Benjamin was important to the Chronicler, and the Chronicler's approach to Benjamin differed from that of the Deuteronomist.

At this juncture it seems demonstrable that in highlighting Benjamin, both the Deuteronomist and the Chronicler are consistent with the rest of the Hebrew Bible and in line with

\footnotetext{
${ }^{161}$ Jonker, "Revisiting the Saul Narrative," 298.

162 Jonker, “Of Jebus, Jerusalem and Benjamin,” 86.
} 
much of the archaeological evidence. The "Benjamin question" is quite relevant to the interpretation of the Hebrew Bible. Whether the Deuteronomist and the Chronicler provide the same "answer" to the question is the subject of the remainder of this study. 


\section{PART II}

\section{Chapter 5: Benjamin in the Deuteronomistic History}

\subsection{GOAL AND METHOD}

\subsubsection{Introduction}

The previous three chapters have been primarily devoted to historical concerns: historicalcritical method, historiography, and the historical backgrounds of the Deuteronomistic History and Chronicles in the Babylonian and Persian periods. The next two chapters will focus on the literary portrayals of Benjamin and intertribal relations in these two historical writings.

Many studies of individual passages, persons, places and themes pertaining to Benjamin have been conducted previously by a wide range of scholars with diverse goals and interests. Rather than expounding the relevance of a single passage in the DtrH or Chronicles for understanding the historical context of Yehud, this study aims to compile a comprehensive account of Benjamin in these two collections - two "snapshots" of an important tribal identity.

\subsubsection{Criteria for Inclusion and Evaluation}

These two chapters will evaluate the portrayal of various tribal identities, persons and places relating to Benjamin within the DtrH and Chronicles. The evaluation of each Benjaminite reference will take into account the context of the portrayal within the larger pericope, chapter, section, and book as a whole. The aim is not simply to provide a "thumbs-up or thumbs-down" judgment, but rather to consider the relation of the author's positive, negative, mixed or vague assessment of a tribe/person/place to the greater narrative context. References to Judahite and Northern tribes in relation to Benjaminite material will also be considered within the scope of this investigation.

As observed in the previous chapter, tribal identities are constructs understood through the biblical texts, not notions derived from material evidence. Thus, the biblical narratives themselves will largely determine the criteria for identifying individual persons or places with tribes. The tribal allocations found in Numbers 32, 35; Deuteronomy 4:41-49; and Joshua 13-21 will serve as a starting point, although — as was shown previously — the tribal identifications of various towns and regions appear to have changed over time. 


\subsubsection{Challenges}

Several caveats need to be considered from the outset. First, there are significant textual problems with some of the relevant passages, particularly in the book of Samuel. As outlined in chapter three, the general approach of this study is to work primarily with the MT but to consider other witnesses to the DtrH and Chronicles where necessary (cf. §3.1.2). However, since the general narrative structure of these books does not differ significantly in the other extant witnesses, once a reference to a particular person/place is established in the text, the evaluation of that person/place should not vary significantly between the MT and the other witnesses.

Second, as has been noted previously, the portrayal of a certain tribe/person/place needs to be understood in the context of the ideological perspectives of the various texts-e.g., Northern, Southern, or Levitical orientation.

Finally, it must be acknowledged that not all Benjamin-related material in the DtrH and Chronicles is necessarily freighted with intertribal concerns. The inclusion of certain historical material may have been driven by non-intertribal concerns: other ideological/theological motivations, or (perhaps) even the earnest desire to portray an event wie es eigentlich gewesen-as the author understood it to have happened.

\subsection{THE BOOK OF JOSHUA}

\subsubsection{Sources and Structure}

The book of Joshua includes a variety of both Northern- and Southern-oriented traditions. The narratives pertaining to Benjamin and that tribe's relation to Judah and Joseph are notably ambiguous.

Joshua gives the appearance of containing at least three sorts of traditions. Joshua 2-11 forms a pre-Deuteronomistic core story of the conquest, which may itself have been compiled from earlier sources. ${ }^{1}$ The account of tribal allotments (Josh 13-21) forms another distinct tradition, with its own sources and editorial activity. ${ }^{2}$ Finally, Deuteronomistic editorial activity may be found at

${ }^{1}$ Richard D. Nelson, Joshua: A Commentary (OTL; Louisville: Westminster John Knox Press, 1997), argues, "A group of discontinuous stories have been interlocked together into a larger written narrative, one that had an independent existence before being later incorporated into DH" (7); see also Jerome F. D. Creach, Joshua (Interpretation Series; Louisville: John Knox, 2003), 10.

${ }^{2}$ Nelson calls the redactional history of this section "less clear" (Joshua, 8). The Judahite and Benjaminite town lists (Josh 15:21-63; 18:21-28) may originally come from an administrative document used during the monarchic period; see Hartmut N. Rösel, Joshua (HCOT; Leuven: Peeters, 2011), 245. 
the seams of these sections and at the open and close of the book. ${ }^{3}$ Some scholars have suggested a few affinities to the Priestly tradition of the Pentateuch, but this link is not conclusively accepted. ${ }^{4}$ Of particular interest to this study is the incorporation of Josephite and Northern elements into a work that in its final form is firmly Deuteronomistic, with concomitant Judahite emphasis. Also of note is the strong Benjaminite presence within both of the core sections of the book (Josh 211, 13-21).

After a consideration of the figure of Joshua himself, the latter half of Joshua will be examined prior to the first half of Joshua, since the Benjaminite apportionments in Joshua 18 will be used to establish the relevance of the locations mentioned in Joshua 1-12 for the present study.

\subsubsection{Joshua (Character)}

Joshua, the successor to Moses (Deut 31:7-23; 32:44; 34:9; Josh 1:1-9), is described as a tribal leader of Ephraim (Num 13:8). His actions may therefore reflect positively or negatively on Ephraim as a whole, particularly his treatment of Judah and Benjamin. ${ }^{5}$

Like most of the major characters in the DtrH, Joshua receives both positive and negative assessment. In the Pentateuch, Joshua stands with (Judahite) Caleb as the only two spies who gave a faithful assessment of the Promised Land (Num 14:6-9, 30, 38; 26:65). In the book that bears his

${ }^{3}$ Creach notes, "The Deuteronomistic editing is particularly evident in Joshua 1, 12; 21:43-22:6; and 23, where these sections supply introductory or summary information in the style of the book of Deuteronomy" (Joshua, 10).

Nelson further argues, "[The] deuteronomistic [sic] redactional presence is visible throughout much of Joshua, but noticeably absent from the description of land distribution (chaps. 13:1-21:42 apart from 14:6-15). These deuteronomistic elements associate the story of Joshua with the larger topic of Israel's national existence as the people of Yahweh. Deuteronomistic language is most apparent in those sections that speak of obedience to the law and the theological significance of the conquest. It seeks to link Joshua's conquest to the previous account of Moses as a military leader and lawgiver and to the future story of Israel in the land (1:1-18; 8:30-35; 12:1-6; 21:43-22:6; 23:1-16). This deuteronomistic material represents more than just a series of isolated expansions or incidents of retouching, but is a comprehensive redaction or act of authorship" (Joshua, 6).

${ }^{4}$ See discussion in Robert G. Boling \& G. Ernest Wright, Joshua: A New Translation with Notes and Commentary (ABC; Garden City, NY: Doubleday, 1982), 56-59, 66-72.

Nelson admits that some apparently Priestly material may be found in the book, particularly in Josh 13-21but "to go so far as to link this minor redactional activity with the Priestly writing in the Pentateuch, however, is to go beyond the evidence" (Joshua, 9).

${ }^{5}$ This study is chiefly concerned with the literary figure of Joshua found in the text's final form. Some scholars consider the Joshua element to be a later addition that binds the stories of Josh 2-11 together; Nelson suggests: "Because chapters 2-9 center on the territory of Benjamin, Joshua is often thought to be a somewhat later addition to these stories, perhaps as a unifying element added in the first stage of collecting and writing. As an Ephraimite hero, he may have been most originally at home in the Divine Warrior narrative centered on Ephraimite Beth-horon (10:10-14)" (Joshua, 21). 
name, Joshua's preparations and conquests (Josh 1-6) reflect faithfulness to YHWH, as do his later conquests (Josh 10-11) and final acts (Josh 22-24). The episodes at Ai (Josh 7-8) and Gibeon (Josh 9) are blemishes on his record. The covenant renewal and reforms he initiates (24:19-28) last only as long as the elders who outlive him (24:31).

With regard to the apportionment of the land (Josh 13-21), Joshua oversees first Judah's inheritance (15) and then that of his own tribe of Ephraim (16). When the Josephites complain to Joshua about the size of their inheritance, Joshua acknowledges their size but encourages them to take initiative in conquering more territory (17:14-18). Joshua receives his own inheritance from the Israelites (19:49-50) only after the rest of the tribes have received theirs (save for the Levitical/refuge cities: 20-21). The narrative of Joshua's inheritance forms an inclusio with the narrative of Caleb as the first to receive an inheritance in the Cisjordan (14:6-14). As will be shown below, the narrative of the apportionment is balanced between the greater tribes; to the extent that Joshua was responsible for this apportionment, it does not appear from the narrative that he could be charged with partiality toward Ephraim.

\subsubsection{Tribal Allotments (Josh 13-21)}

Joshua 13-18 describes the tribal allotments for Judah, the Josephite tribes, and Benjamin. The order and rationale of these allotments is of particular interest for later intertribal relations.

After Caleb, the tribal head of Judah (cf. Num 13:6; 34:19), receives his territory (Josh 14:615), Judah (15), Ephraim (16), and Cisjordan Manasseh (17:1-13) receive their allotments from Joshua. The task of apportionment for the remaining seven tribes is then a separate procedure: the remaining land is mapped and divided by twenty-one tribal representatives, and lots are drawn for each of the seven divisions (18:1-9). Benjamin's lot from "before YHWH" is drawn first, "and the territory allotted to it fell between the tribe of Judah and the tribe of Joseph" (18:10-11). When recounting the apportionment of cities to the Levites (21), the Deuteronomist is careful to associate the Aaronides with Judahite cities only: "thirteen towns from the tribes of Judah, Simeon and Benjamin” (21:4; cf. 21:17-18).

Hawk notes the level of detail with which some of the borders and towns are described. Judah's northern border in particular is described "with meticulous precision." " Judah's list of towns (15:20-63) is organized in a twelve-part scheme, highlighting the four geographical regions of Judah: "extreme South (v. 21), the Lowland (v. 33), the hill country (v. 48), and the wilderness (v. 61)."7 The borders (18:11-20) and towns (18:21-28) of Benjamin are described with similar

\footnotetext{
${ }^{6}$ L. Daniel Hawk, Joshua (Berit Olam; Collegeville, MN: Liturgical Press, 2000), 199.

${ }^{7}$ Hawk, Joshua, 202-203.
} 
precision, elegance and structure. ${ }^{8}$ Some scholars suggest that these town lists are derived from a monarchic-era administrative source. ${ }^{9}$

By contrast, the description of the Josephite allotment is messy, divided, and incongruous. ${ }^{10}$ Only the southern boundary of Ephraim and Manasseh is described in the Josephite allotment (16:13); ${ }^{11}$ some Ephraimite towns are included within Manasseh's borders (16:9); some Manassite towns are included within the territories of other Northern tribes (17:11); and Manasseh itself is divided into western and eastern territory (17:1-6). ${ }^{12}$ The account of the inheritance of the six remaining "northern" 13 tribes is "disordered and fragmented," displaying "diverse structures and various states of cohesion." 14

Hawk also notes that the territorial layouts include towns and regions that were never actually fully conquered by Israel, which "insinuates a measure of failure" in the attempts to occupy the allotted land: ${ }^{15}$ Judah fails to conquer Jerusalem (15:63); Ephraim fails to conquer Gezer (16:10); Manasseh fails to possess its allotments within other Northern tribes (17:11-13); the Josephites together cannot dispossess Beth-shean and Jezreel (17:16). The Danites-the last to receive their lot—cannot take possession of their southern territory, so they migrate north to Leshem (19:47-48).

The balanced presentation of Judah's primacy is notable in these chapters. Caleb and Judahites receive the first and largest allotments in the Cisjordan, and are given speaking roles and short vignettes (14:6-15; 15:13-19). But Judah's primacy is offset in several ways. First, the Transjordan tribes, including Reuben — the supplanted firstborn tribe—and half-Manasseh—a Josephite tribe-have previously received their inheritances from Moses, Joshua's mentor/superior (Num 32; Josh 13). Furthermore, Caleb, the first Judahite to receive an inheritance, is actually a

${ }^{8}$ Hawk, Joshua, 216-217.

${ }^{9}$ Nelson, Joshua, 8. Rösel explains: "Before its division by the author of the book of Joshua the joint list covered the area of the kingdom of Judah. Clearly therefore this list dates from the period of the monarchies after the 'division of the kingdoms.' Originally it served the administration of that period. The exact date of the list depends on the towns mentioned (or missing), but it is disputed among the scholars. The main proposals fluctuate between the $9^{\text {th }}$ and the $7^{\text {th }}$ century BCE" (Joshua, 245).

${ }^{10}$ Hawk, Joshua, 203.

${ }^{11}$ Hawk, Joshua, 205.

${ }^{12}$ Hawk, Joshua, 207.

${ }^{13}$ Simeon and Dan later came to be associated with the North. Dan migrated to the north (Josh 19:47-48; Jdg 18); Simeon was absorbed into Judah but still literarily and theologically “counted” as a Northern tribe (see $\$ 4.1 .2 \mathrm{n} 20$ ).

${ }^{14}$ Hawk, Joshua, 217.

${ }^{15}$ Hawk, Joshua, 202-203. 
Kenizzite according to the narrative: a non-Israelite "naturalized" into Judah (14:6, 14). ${ }^{16}$ Third, Judah's dispossession of the land is incomplete: they fail to drive out the Jebusites, who continued to live in Jerusalem (Josh 15:63) — though Judges 1:21 "corrects" this by placing the blame on Benjamin. Fourth, the Josephite tribes likewise receive large, pre-survey (18:1-9) allotments, and are also given speaking roles and a corresponding vignette concerning apportionment to female heirs (the daughters of Zelophehad: 17:3-6; compare to Achsah story: 15:16-19). This section maintains a careful balance of emphasis and power between Judah and the primary Northern tribes of Ephraim and Manasseh-and Benjamin is directly in the center of that balance.

According to Joshua 18:11-28, Benjamin's allotment includes the notable locales of Bethaven (cf. Hos 5:8), Jericho, Beth-arabah, Zemaraim, Bethel, Avvim, Parah, Ophrah, Geba, Gibeon, Ramah, Be'eroth (cf 2 Sam 4:2-3), Mizpah, Rekem, Jebus/Jerusalem, and Gibeah. ${ }^{17}$ Several of these places are elsewhere associated with other tribes:

- Beth-arabah (15:61) and Jebus/Jerusalem (15:63) are also listed within Judah's tribal allotment.

- 2 Chronicles 13:4 places "Mount Zemaraim" within the hill country of Ephraim.

- Jericho and Bethel mark the border of Josephite and Benjaminite territory (Josh 16:1-2), but the cities themselves are Benjaminite. ${ }^{18}$

- A town called Ophrah is the home of Gideon, a Manassite judge (Jdg 6:11, 24; 8:27, 32; 9:5).

- Other tribes possess towns called "Ramah" (Simeon, 19:8; Asher, 19:29; Naphtali, 19:36). Benjaminite "Ramah" (cf. Isa 10:29; Hos 5:8) is associated with Ephraim as well (1 Sam $1: 19 ; 2: 11)$.

- Another Mizpah is associated with Gilead of Manasseh (Jdg 10:17; 11:11, 29, 34).

${ }^{16}$ Creach, Joshua, 101. Joshua 14 and Num 32:12 designate Caleb as a Kenizzite, one of the peoples that will be dispossessed by Abraham's descendants (Gen 15:19). The genealogy of 1 Chr 2 "grafts" Caleb (כלב) into the line of Judah (2:42-50a) by linking him with Hezron's son of a similar name (כלב / כלובי 1 Chr 2:9, 18-20, 50b-55). Willi argues that the inclusion of Caleb is for the Chronicler a strength of Judah's line, and indicates “the Chronicler's inclusive view of Judah"; see Willi, "Late Persian Judaism and its Conception of an Integral Israel According to Chronicles: Some Observations on Form and Function of the Genealogy of Judah in 1 Chronicles 2.3-4.23," in Second Temple Studies 2. Temple Community in the Persian Period (ed. Tamara C. Eskenazi and Kent H. Richards; Sheffield: Sheffield Academic, 1994), 159.

${ }^{17}$ Towns and cities not mentioned elsewhere in the Hebrew Bible include: Beth-hoglah, Emeq-qeziz, Kepharammoni, Ophni, Kephirah, Mozah, Irpe’el, Taralah, and Zela'-ha'eleph.

${ }^{18}$ Nadav Na'aman, “Saul, Benjamin and the Emergence of 'Biblical Israel' (Parts 1 \& 2)," ZAW 121 (2009): 218-220. 
- Rekem is part of the Transjordanian Midianite territory given to Reuben (Num 31:8; Josh $13: 27)$

The ambiguous statuses of these locales may indicate mixed populations, shifting tribal borders, fluidity of tribal identity, or merely editorial and scribal activity. In this study, these "Benjaminite" sites and their subsequent association with other tribes will be examined on a case-by-case basis.

The most important of these tribally ambiguous cities-important in the Hebrew Bible and in our study-is Jerusalem. Jerusalem's future prominence as David's capital and the location of the temple, "the place in which the LORD your God will choose for His name to dwell" (Deut 12:11), is only foreshadowed. But from the first references to this location, its importance becomes apparent as a border ground between the territory of Benjamin—which traditionally encompassed the Jebusite areas — and the inheritance of Judah. ${ }^{19}$

Reading retrospectively in the book of Joshua, it is remarkable that nearly all of the conquest narrative is set in what would later become Benjaminite territory. This includes the episodes at Jericho (Josh 2-6) and Gibeon (Josh 9-10). The small town of Ai, the site of Israel's defeat and subsequent victory in the Achan affair (Josh 7-8), is not mentioned in the tribal allotments, but is said to be between Bethel and Beth-aven (Josh 7:2). Elsewhere, Ai is closely tied to Bethel (Josh 8:9-17; 12:9; Ezr 2:28//Neh 7:32), indicating that the town is within Benjaminite territory.

\subsubsection{Victory at Jericho (Josh 2-6); Ai and the Achan Affair (Josh 7-8)}

The narratives of the conquests of Jericho and Ai are set primarily in Benjaminite territory. Intertribal dynamics are significant in these narratives.

The Jericho narrative begins with the Israelite spies sent to Jericho from Shittim in the Transjordan (Josh 2), and concludes with utter victory over Jericho (Josh 6). The middle chapters contain various echoes of Pentateuchal stories: the crossing of the Jordan dry-shod (Josh 3), the making of a stone memorial (Josh 4; cf. Deut 5:22; 27:1-8), the re-sanctification of Israel through circumcision (Josh 5:1-9; cf. Exod 4:24-26), and the celebration of the Passover (Josh 5:10-12).

The unity, integrity and purity of the twelve tribes are essential components of Israel's success in these chapters. Soldiers from the Transjordan tribes accompany the rest of Israel into Canaan (4:12-13). Representatives of each tribe are chosen to place stones in the middle of the

${ }^{19}$ Creach (Joshua, 102) argues that the outline of Judah's territory is "carefully drawn so as to exclude Jerusalem," so that it is clear that "Jerusalem was not an Israelite city until David captured it and made it his capital (2 Sam. 5:6-15; but see Judg. 1:8)." This puts a slightly different spin on the tribal identity of the city: according to DtrH, Jerusalem should have been Benjaminite, but by David's final act of “conquest," it became part of Judah. 
Jordan while the people cross, and then to retrieve those twelve stones for a memorial at Gilgal (3:12; 4:2-9, 20-21). YHWH's instructions at Jericho include "all" the people $(6: 3,5,20)$ and must be followed precisely for success.

By contrast, the debacle at Ai results from the fragmentation of the people and the sin of a single Judahite. Concerning Joshua 7:3, Hawk comments: “[The spies'] suggestion that "not all the people need to go up' divides the community, breaking the 'all Israel' integrity necessary for success. 'All Israel' wins battles against the fragmented Canaanite peoples, but the 'not all' character of this attack presages a reversal." ${ }^{20}$ Achan of Judah likewise breaks the integrity of Israel by keeping Canaanite חרם for himself (7:13, 20-24). Once the integrity of Israel is restored by Achan's destruction (7:25), "all Israel" is able to conquer Ai through an elaborate, concerted assault (8:1-29; especially vv. 1-3, 24: "all" the people). The narrative concludes with the covenantrenewal ceremony at Shechem commanded by Moses (Josh 8:30-35; cf. Deut 27).

These chapters provide aetiologies of important non-Benjaminite cultic sites, including Gilgal (Josh 4-5) ${ }^{21}$ and Mts. Ebal and Gerizim (Josh 8:30-35). Also included are two major military successes and one failure, all within territory that would become Benjaminite (Josh 6-8). A Judahite is responsible for the near-disaster, but an Ephraimite carefully follows YHWH's instruction and saves Israel (Josh 7:16-8:2).

\subsubsection{Israel and the Gibeonites (Josh 9-10)}

Joshua 9 describes the deception of Israel by the Gibeonites. The Gibeonites are apparently "Hivvites" (9:7) who inhabit the towns of Gibeon, Chephirah, Be'eroth and Kiriath-jearim (9:17). The key moments in the narrative include the failure of the men of Israel to "inquire of the mouth of YHWH" (9:14), the oath sworn to the Gibeonites by the leaders of the assembly (9:15), and Joshua's decree that the Gibeonites be "wood-cutters and water-bearers" for their deception (9:21b, $9: 27)$.

Na'aman reads the story of the Gibeonite deception (Josh 9) through the lens of competition between the cultic sites of Gibeon and Jerusalem in the late monarchic or Babylonian period. ${ }^{22} \mathrm{He}$ speculates:

The YHWH temple at Gibeon was probably abolished in the course of Josiah's religious reform. The

Gibeonites' strong opposition to the closing of their temple is reflected in the satirical polemic

${ }^{20}$ Hawk, Joshua, 112.

${ }^{21}$ Schunck notes that the sanctuary at Gilgal (Josh 4-5) lies on the border between the Benjaminite and Ephraimite regions; Klaus-Dietrich Schunck, "Benjamin,” Anchor Bible Dictionary, vol. 1. (trans. Phillip R. Callaway; ed. David Noel Freedman; New York: Doubleday Publishing, 1992), 671.

${ }^{22}$ Nadav Na'aman, “The Sanctuary of the Gibeonites Revisited,” JANER 9 (2009): 101-124. 
initiated by a Dtr author against the Gibeonites and their elders. They are portrayed as dishonest foreigners who entered the covenant by fraud and were appropriately condemned to serve as menial workers of lower rank in the temple of Jerusalem. ${ }^{23}$

Na'aman's concluding assertion is based on 9:27b, which states that the Gibeonites should serve "the altar of YHWH...at the place which he will choose" - an unambiguous echo of Deuteronomy 12 , referring to Jerusalem.

$\mathrm{Na}$ 'aman's laudable attempt to interpret the Gibeonite treaty narrative in light of later concerns reveals a contrast with the positive portrayal of Gibeon in the following chapter: YHWH causes the sun to stand still at Gibeon at Joshua's request (10:12-13), and uniquely heeds a human voice ("There has been no day like it before or since, when YHWH listened to the voice of a man; for YHWH fought on Israel's behalf'; 10:14). The juxtaposition of these two Gibeon stories may reflect the contested status of this Benjaminite town as a cultic center.

\subsubsection{Summary}

Intertribal relations are most prominent in the book of Joshua in the apportionment of inheritances in Canaan. Elsewhere in the book, great victories are won and miracles performed at Benjaminite sites-yet important Northern sites are established as well. Large allotments are given both to Judah and the Josephite tribes, with Benjamin occupying a clearly-delineated middle region. ${ }^{24}$ The great heroes of Israel named in the book belong to Ephraim (Joshua) and Judah (Caleb).

The delicate tribal balance in Joshua results from the blending of Northern and Southern traditions. At this early point in the Deuteronomistic narrative, the beginnings of Judah's primacy are already evident in its size and assigned location.

\subsection{THE BOOK OF JUDGES}

Intertribal dynamics are perhaps more varied and complex in the book of Judges than in any other book of the DtrH. Though the book is somewhat pro-Judah (pro-David) in its final form,

${ }^{23}$ Na'aman, "The Sanctuary of the Gibeonites Revisited," 117.

${ }^{24}$ Rösel discusses whether Josh 15-17 is structured around a "Judah-Joseph" duality, which, he argues, would be indicative of divided-kingdom-era concerns_-or, whether the section uses terminology that evinces a more ancient tribal structure (hence, "Ephraim" and "Manasseh"). The argument for the tribal emphasis seems stronger, though Rösel concedes that this may yet reflect a later hand: "Although the Judah-Israel duality is prominent in the present version, the place of Benjamin (and Simeon) at the end indicates that the tribal aspect, and not the two-kingdoms aspect, is basic. But it is also true that this reflects the intention of the comparatively late biblical author, whose aim was to render a description of tribal territories" (266-267). 
Judges contains Northern and Southern traditions, and continues Joshua's ambiguous portrayal of Benjamin.

\subsubsection{Structure and Characterization}

Schneider observes, "The book of Judges is concerned with seeking an answer to a straightforward question, 'Who is going to lead Israel?",25 A "judge” in ancient Israel (שיפטיט) not only performed a judicial role, but also possessed the leadership ability and military might to enforce judgments and to "set things right" for his people in relation to other nations (cf. Jdg 2:16). Each of the first two judges described in the book is called a "savior" (מושיע). Judges likely ruled regionally and concurrently over Israelite tribes in a loose confederation.

If the key question of the book of Judges is who should lead Israel, YHWH provides an answer at the beginning and end of the book: Judah (1:2; 20:18). Judges underscores Israel's need for a king — more precisely, a king from Judah. The book incorporates remarkable traditions concerning mostly Northern heroes, but in the final assessment none of them is worthy to lead Israel. $^{26}$

The book begins with Othniel, the model judge, and ends with Samson, who is so negatively evaluated that he not only dies in battle with foreigners, but his death leads to anarchy in Israel. These poles, Othniel and Samson, highlight the steadily decreasing worth of the judges over time, and at the same time, the downward spiral of all of Israel. ${ }^{27}$

Neither is a Benjaminite — especially one from Gibeah (Jdg 19)—worthy to be king. Only a Judahite, such as Othniel, should permanently lead Israel—all other leaders are temporary solutions at best, and utter failures at worst.

\subsubsection{Conquests after Joshua (Jdg 1:1-36)}

The narrative of the conquests after the death of Joshua overlaps and conflicts with the conquest and apportionment narratives in Joshua 2-21. Judges 1 describes the re-conquest of some regions and towns that had already been conquered under Joshua, according to the book of Joshua. The acknowledgement that much of Canaan had yet to be conquered under Joshua is consistent with Joshua 13:1-6 but at odds with the numerous statements to the effect that the Israelites had subdued the entire land under Joshua (Josh 11:15-17, 23; 21:43-45).

\footnotetext{
${ }^{25}$ Tammi J. Schneider, Judges (Berit Olam; Collegeville, MN: Liturgical Press, 2000), xiv.

${ }^{26}$ Of the major judges, only the lone female judge-Deborah—is exclusively characterized positively.

${ }^{27}$ Schneider, Judges, xiv.
} 
Judges 1 describes the campaigns of various tribes and tribal coalitions in turn. Each success לא הוריש את־ : לא accompanied by a failure to dispossess certain Canaanites (indicated by the refrain “They did not dispossess ...").

Judah's conquest is first and receives the most attention. Judah is specified by YHWH as the leader of Israel in this venture:

\begin{abstract}
Now after the death of Joshua, the sons of Israel inquired of YHWH, saying, "Who will go up for us against the Canaanites first, to fight against them?" And YHWH said, "Judah will go up; behold: I have given the land into his hand." (Jdg 1:1-2)
\end{abstract}

The narrative then follows the campaigns of Judah and Simeon together (1:3-7); Judah (1:8-10); the Kenizzites, including Caleb, Othniel and Hobab (1:11-16); and Judah and Simeon together (1:1720). The Judahites and their allies experience nearly complete success: Hobab and his people live alongside the Amalekites (1:16), and Judah fails to dispossess the "inhabitants of the plain, because they had chariots of iron" (1:19).

The remainder of the chapter highlights the unsuccessful campaigns of the other tribes. The lone "Benjaminite" campaign is a failure; Judges 1:21 has modified Joshua 15:63 to shift the blame for the continued Jebusite presence in Jerusalem away from Judah onto Benjamin. Joseph, not Benjamin, conquers Bethel, but allows the lone Canaanite to escape with his family to found a new "Luz" in the land of the Hittites (1:22-26). Manasseh and Ephraim fail to possess certain towns (1:27-29), but are able to put some Canaanites to forced labor. Similarly, the minor Northern tribes are unsuccessful in dispossessing the Canaanites (1:30-36), with the final failure of Dan representing the nadir of the conquest account. ${ }^{28}$

Judges 1 is rather pro-Judah in its orientation. Judah is chosen by YHWH to lead. Judah receives the most attention, and is the only successful tribe in these post-Joshua campaigns. Nevertheless, the presentation of Judah is not entirely positive. Judah seeks assistance from Simeon immediately after YHWH's guarantee of victory, which could be construed as a lack of faith (1:3). Hobab, an ally of Judah, settles among the Amalekites rather than dispossessing them (1:16). Judah, though "YHWH was with him," cannot dispossess the Canaanites of the plain (1:19).

${ }^{28}$ K. Lawson Younger, "Judges," in The New Oxford Annotated Bible (NOAB), Michael D. Coogan, ed. (New York: Oxford University Press, 2007), 356. 


\subsubsection{The First Judges: Judahite and Benjaminite (Jdg 3:7-30) ${ }^{29}$}

The presentation of Israel's first two judges, Othniel and Ehud, is highly significant for Judah-Benjamin-Joseph relations in the book of Judges. First, since Judah has already been designated by YHWH as the leading tribe, the expectation is that Israel's leader should come from Judah — so the audience eagerly awaits an account and evaluation of the first judge. Second, the narrative juxtaposition of the two leaders from Judah and Benjamin invites comparison of their record, and anticipates the juxtaposition of Israel's first two kings from the same tribes. Othniel calibrates the audience's expectation of the role of "judge," and subsequent judges—-beginning with Ehud-are compared to him.

The narrative of Othniel's judgeship in Israel (3:7-11) is a concise, prototypical iteration of the so-called "Judges cycle": 1) Israel forgets YHWH and worships other gods; 2) YHWH gives Israel over to oppression; 3) Israel cries out to YHWH for deliverance; 4) YHWH raises up a deliverer who leads Israel to victory over the oppressors; and 5) the land and people are granted "rest" for a time. No details are provided about the oppression, Othniel himself (other than his relation to Caleb), the rebellion, or the time of peace. The only specific positive features of Othniel's leadership are that "the spirit of YHWH camp upon him" (3:10), and that the land had rest for forty years under his judgeship—a complete generation (3:11).

The lack of detail concerning the tenure of this "major" judge from the leading tribe of Israel contrasts sharply with the detailed accounts of the character and actions of other major judges from Benjamin and the Josephite tribes. The account of Othniel's judgeship is terse, stylized, and idealized. The reader is left to wonder whether closer scrutiny of Othniel and his tenure would reveal the same sorts of flaws and failures of the other judges.

Indeed, a close reading of the earlier narrative concerning Othniel (Jdg 1:11-15//Josh 15:1519) may call into question Othniel's character and his legitimacy. Schneider discusses the relationship between Achsah and Othniel in this passage and observes, like many scholars, the suggestive nature of the language surrounding her "arrival" with (בואה) and "urging" of (ותסיתהו) Othniel. ${ }^{30}$ It is also of note that the prototypical "Judahite" judge is actually a Kenizzite, naturalized into Israel. The more the reader learns about Othniel, the more potential flaws are discovered.

${ }^{29}$ Izban the Bethlehemite (Jdg 12:8-10) is understood by most commentators as hailing not from Bethlehem of Judah/Benjamin, but from the northern Bethlehem of either Asher or Zebulun (cf. Josh 19:15). See Schneider, Judges, 187-188; Younger, "Judges," 375.

${ }^{30}$ Schneider, Judges, 10-17. The use of בואה is understood with sexual connotation as Achsah "enticing" her new husband to ask her father for a field. The LXX acknowledges the difficulty for a patriarchial context by altering the text (or reflecting a "smoothed over" Vorlage) to place Othniel in the active role, commanding his wife 
Schneider observes concerning Judges 3:7-11:

The description of [Othniel's] tenure in office reveals the bare essentials of the office. This is the perfect situation for a model. Too many particulars would confuse the essential elements. The downward spiral of Israel is reflected in her later judges who erred in the elaboration and details of the model set by Othniel. To a certain extent, too many details concerning Othniel, especially if one wants to question the legitimacy of Caleb's vow and Othniel's winning Achsah, could tarnish his image. $^{31}$

By contrast, the account of Ehud, the left-handed Benjaminite judge, is filled with details about the hero himself, his "heroic" act, and the successful rebellion (3:12-30). The Ehud narrative is as elaborate, comical, and ignoble as the Othniel narrative is terse, dignified, and idealized.

Ehud is far from the "ideal" judge. ${ }^{32} \mathrm{He}$ is, with comical irony, a left-handed (אטר יד־ימינו "right-hand-hindered") Benjaminite ("right-hand son"). Left-handedness has, in many cultures throughout history, been looked upon with suspicion. ${ }^{33}$ He kills Eglon of Moab, not nobly in handto-hand combat or on the battlefield, but secretly while the king is "covering his feet." Ehud then escapes through the latrine. ${ }^{34}$

The pair of references to the פסילים at Gilgal $(3: 19,26)$ has been understood by some as reflecting negatively upon Ehud. Ehud twice appears to travel out of his way ${ }^{35}$ to pass by the "idols/images which were in Gilgal" (הפסילים אשר את־הגלגל). Several interpretive decisions will determine if and how these verses are intended by the narrator to impugn Ehud's character:

- Are the פסילים in fact "engraved idols/images," or are they merely the stones erected at YHWH's command under Joshua (Josh 4-5)?

to ask her father for a field: $\kappa \alpha \iota \varepsilon \pi \varepsilon \sigma \varepsilon ı \sigma \varepsilon v \alpha v \tau \eta \nu ~ \Gamma o \theta o v \imath \eta \lambda \tau o v \alpha \iota \eta\rceil \sigma \alpha \pi \alpha \rho \alpha \tau o v \pi \alpha \tau \rho \circ \varsigma \alpha v \tau \eta \varsigma \alpha \gamma \rho o v$. In both versions, Achsah herself ultimately speaks to her father, perhaps because her husband lacks the courage to do so (1:15).

${ }^{31}$ Schneider, Judges, 40.

${ }^{32}$ Negative evaluations of Ehud include: Lillian R. Klein, The Triumph of Irony in the Book of Judges (JSOTSup 68; Sheffield: Almond Press, 1988), 38, 46-47; Robert H. O'Connell, The Rhetoric of the Book of Judges (VTSup 63; Leiden: Brill, 1996), 97-98.

${ }^{33}$ In the ANE, as in Near Eastern cultures today, the right hand was considered the hand of friendship; an offer of the left hand was an insult. Traces of this sentiment can be seen in modern English, with the word "sinister" derived from the Latin sinistram, "left."

${ }^{34}$ Note the comical wordplay in 3:22-23: Eglon's “stool came out" (ויצא הפרשדנה), and Ehud "went out through the latrine" (ויצא אהוד המסדרונה). This accentuates the ignobility of Ehud's heroism.

${ }^{35}$ This interpretation is based on the geographical relation of Geba (Ehud's hometown), Jericho, Gilgal, and the Ephraimite hill country. Ehud twice departs from Jericho and travels not westward toward Geba or northwest toward Ephraim, but northeast to Gilgal. 
- Does Ehud actually engage in worship at the or is he perhaps filled with zeal to rescue YHWH's people at the detestable sight?

- Alternatively, is the pilgrimage to Gilgal part of a ruse to deceive Eglon into thinking that Ehud has indeed received "a word from the gods" $(3: 20) ?^{36}$

- If Ehud does engage in worship, is it the worship of other gods, or "unorthodox" (in the author's view) Yahwistic worship?

The Deuteronomist's use of word פסילים, the root of which includes the idea of "cutting," elsewhere פסילים or not, the fact that he allows them to stand (and never destroys them, as Gideon later destroys the altar to Baal) does appear to diminish Ehud in the Deuteronomist's estimation. O'Connell suggests a connection between Ehud's (in)action and the transgressions of the Benjaminite first king of Israel:

If fault may be leveled against Ehud for allowing the 'idols' near Gilgal to remain standing (Judg. $3: 19,26)$, there may be some degree of correspondence to the fact that Saul was later confirmed as king at Gilgal and that both transgressions that disqualified Saul from kingship were likewise cultic: the first again at Gilgal (1 Sam. 13:7b-14) and the second for sparing the life of the Amalekite king (1 Sam. 15:1-31). Incidentally, the references to the 'idols' in the Ehud account form an inclusio that frames the description of Ehud's assassination of the Moabite king in much the same way that the accounts of Saul's cultic transgressions in 1 Sam. 13:7b-14 and 15:1-31 form an inclusio that frames the account of Saul's disqualification. ${ }^{38}$

Two potentially positive aspects of Ehud's characterization should be noted. ${ }^{39}$ To the extent that craftiness is a valued trait in the Hebrew Bible, Ehud certainly displays this trait in his creative assassination of Eglon. Second, both the MT and the LXX record that the period of peace following Israel's defeat of Moab under Ehud lasted eighty years (3:30), twice as long as the peace won by

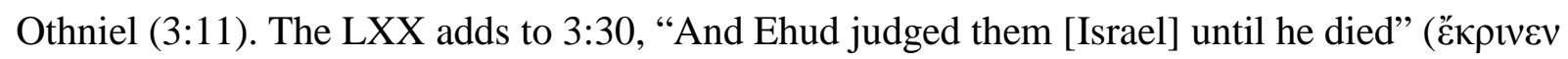

${ }^{36}$ O'Connell, The Rhetoric of the Book of Judges, 95.

${ }^{37}$ Altars to YHWH are supposed to be made of unhewn stones (Exod 20:25; cf. Deut 27:5-6; Josh 8:31).

${ }^{38}$ O'Connell, The Rhetoric of the Book of Judges, 284.

${ }^{39}$ Evaluations of Ehud that are mostly favorable include: Schneider, Judges, 52; Barry G. Webb, The Book of Judges: An Integrated Reading (JSOTSup 46; Sheffield: JSOT Press, 1987), 130-132; Yairah Amit, "The Story of Ehud (Judges 3:12-30): The Form and the Message," in Signs and Wonders: Biblical Texts in Literary Focus (ed. J. Cheryl Exum; Atlanta: Scholars Press, 1989), 97-123; Geoffrey P. Miller, "Verbal Feud in the Hebrew Bible: Judges 3:12-30 and 19-21," JNES 55 (1996): 105-117; Robert B. Chisholm Jr., "Ehud: Assessing an Assassin,” Bibliotheca Sacra 168 (2011): 274-282. 


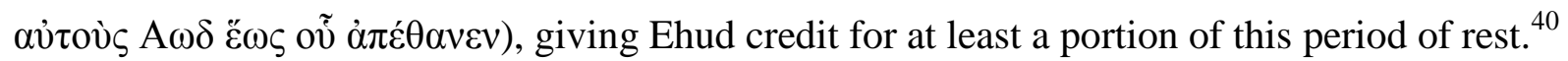
However, both the MT and LXX mitigate Ehud's success in comparison to Othniel's by recording that Moab was "given into/subdued under Israel's hand," rather than Ehud's hand (3:30; cf. 3:28)— whereas Cushan-rishathaim is given into Othniel's hand (3:11).

Schneider notes two further connections between the Ehud narrative and later David-Saul relations. Ehud is described as a "son of Gera," as is Shimei, the "man of the family of the house of Saul" who curses David for usurping Saul's kingdom (2 Sam 16:5; 19:16, $18 ; 1$ Kgs 2:8). Shimei later goes out with Judah to meet David at Gilgal as David crosses the Jordan returning to Jerusalem (2 Sam 19:15-24). These two terms subtly connect Judges 3 and 2 Samuel 16-19:

\begin{abstract}
The incidents in Samuel highlight animosity between the Benjaminites/Saulides and David. Enough similarities exist to read the David/Saul issue into the background of the Judges incident. Ehud's description introduces him not only as a Benjaminite, but, more specifically, one from the Gera clan which will insult David when his kingship is in trouble. Whereas Othniel's designation “younger brother of Caleb" ties him to the previous generations, highlighting his legitimacy, Ehud's designation relates him to Saul through the remnant of Saul's kingship which will gloat at King David's misfortune. Again the contrast favors Judah the victor over what will be the destroyed and humiliated remnants of Saul. Even before Ehud carries out any actions he is already not the model depicted by Othniel. This is another example of the polemic about David and Saul which appears as foreshadowing of events and names in Judges. ${ }^{41}$
\end{abstract}

In summary, the Ehud narrative is as ambiguous as the Othniel narrative is brief. Whether the modern interpreter chooses to assess Ehud's actions in the most sympathetic light, it seems that the ancient storymaker intended to portray Ehud 1) as morally ambiguous at best; and 2) as inadequate beside Othniel. The connections to the Saul/Saulide narratives underscore this comparison: Ehud, like Saul, is a foil for the preferred Judahite ruler.

${ }^{40}$ Does Judges 4:1 tarnish Ehud's legacy? Read strictly literally, the verse indicates that the sons of Israel resumed their evil ways during Ehud's lifetime (ויספו בני ישראל לעשות הרע בעיני יהוה ואהוד מת), but here the use of the wa$\mathrm{X}$ qatal construction seems to indicate background information in the past-perfect sense: “And the sons of Israel once again did evil in the sight of YHWH; now, Ehud had died." See Robert E. Longacre, "Discourse Perspective on the Hebrew Verb: Affirmation and Restatement,” in Linguistics and Biblical Hebrew (ed. Walter Bodine; Winona Lake, IN: Eisenbrauns, 1992), 178-179.

${ }^{41}$ Schneider, Judges, 48. 


\subsubsection{Josephite Judges (Jdg 4-12)}

Judges 4-12 is quite "Northern" in its origin and orientation. Many scholars consider this section to have been part of an original book of Northern saviors, ${ }^{42}$ and as a consequence the section may have been integrated into Judges rather late and undergone relatively little Deuteronomistic editing. ${ }^{43}$ Nearly all the judges described in this section are Josephite or connected to Joseph. Two aspects of this section of Judges are of particular interest to this study: the characterization of these judges in comparison to Othniel and Ehud; and the connections within these stories to Judah, Benjamin, and Benjaminite locations.

Four major judges ${ }^{44}$ and three minor judges are connected with Ephraim or Manasseh: Deborah (Jdg 4-5); Gideon (6-8); Abimelech (9); Tola, an Issacharite who lived in Ephraim (10:12); Jair the Gileadite (10:3-5); Jephthah (10:6-12:7); and Abdon the Pirathonite (12:13-15). Three minor judges receive favorable assessments, as does Deborah, the only female judge.

The three major Manassite judges, by contrast, are each flawed in some significant way. Gideon, despite his faith and eventual courage, exhibits fear (6:11-24, 36-40), lust for personal vengeance (8:1-21), and pride that leads to idolatry in Israel (8:22-27). His ambitious, fratricidal son, Abimelech, attempts to establish an oppressive monarchy in Israel (9). Jephthah exhibits courage and faith, but is undone by a rash vow (11:29-40). None of these figures is able to live up to the standard set by Othniel.

The Joseph-focused section of the book concludes with an intra-Josephite war between the Ephraimites and the Gileadites (12:1-6). The war highlights the inability of these Josephite leaders to unify and rule even their own tribal relatives, let alone all Israel. This conflict also anticipates the pan-Israelite civil war in Judges 19-21, in which Judah is able to unify all Israel against Benjamin.

Benjamin is mentioned twice in Judges 4-12. In the Song of Deborah, Benjamin is associated positively with Ephraim and other Northern tribes; Judah is not mentioned (Jdg 5:14). Judges 10:8-9 record that the Ammonites afflicted "Gilead," and also "Judah, Benjamin, and the

42 Though the extent of this original "Retterbuch" within Judges is debated; see discussions in Robert G. Boling, Judges: A New Translation with Notes and Commentary (ABC; Garden City, NY: Doubleday, 1975), 29-38; Trent C. Butler, Judges (WBC; Nashville: Thomas Nelson, 2009), xlix; Barry G. Webb, The Book of Judges (NICOT; Grand Rapids: Eerdmans, 2012), 20-32.

43 Thomas C. Römer, "Entstehungsphasen des 'deuteronomistischen Geschichtswerkes,"” in Die deuteronomistischen Geschichtswerke: Redaktions- und religionsgeschichtliche Perspektiven zur "Deuteronomismus”Diskussion in Torah und Vorderen Propheten (Markus Witte et al., eds; BZAW 365; Berlin: de Gruyter, 2006 ), 62-63. Römer suggests, "In der Tat ist Jdc das wohl am wenigsten dtr bearbeitete Buch und hat sicher eine vom 'Deuteronomismus' unabhängige Vorgeschichte” (63).

44 That is, if Abimelech could rightly be considered a "judge" — nevertheless, he is an important Manassite leader in Judges. 
house of Ephraim" in the Cisjordan. Israel later prevails over Ammon under the leadership of Gileadite Jephthah (11:32-33).

Benjaminite territory as defined in Joshua 18:11-28 is mentioned briefly in Judges 4-12, which is largely set in Northern territory. Judges 4:5 notes that Deborah judged Israel "between Ramah and Bethel in the hill country of Ephraim." Gideon and Abimelech, Manassites, are natives of a town called Ophrah, and part of the narrative material of Judges 6-9 is set in that town, which should most likely be distinguished from the Benjaminite town of the same name (Josh 18:23). Jephthah, the Gileadite judge, lived in "Mizpah of Gilead" (Jdg 11:29), presumably a Transjordan city without connection to Benjaminite Mizpah.

\subsubsection{Samson, Micah, and the Danites (Jdg 13-18)}

The narratives concerning Samson (Jdg 13-16), Micah, and the migration of the Danites (Jdg 17-18) contain some material relevant to the portraits of Judah and Joseph, but not Benjamin in particular.

The narrative of Samson is set in the period before the tribe of Dan migrated north (Jdg 18; cf. 1:34). Samson, a Danite judge of questionable judgment and moral character, interacts with the Philistines west of Israel. Samson succeeds in inciting the Philistines to march on the Judahites, who promptly negotiate to hand over Samson bound to the Philistines in exchange for peace (15:917).

Samson had the opportunity to champion Dan and dispossess the cities of the Philistines that had been allotted to Dan (Josh 19:40-48), but his decision to consort with the peoples of the land betrays the conquest mandate (e.g., Deut 7:1-6). His utter failure threatens to bring disaster upon the other tribes-Judah, in the case of Judges 15:9-17.

Judges 17-18 links two stories that characterize the immoral and lawless state of Israel without a king $(17: 6 ; 18: 1)$. Several features of the stories are significant for intertribal relations. Micah, an Ephraimite, fashions a silver idol (17:1-5) and hires a personal priest to perform "Yahwistic" rituals on his behalf (17:7-13). His Levitical priest, who is later revealed to be Moses's grandson (18:30), leaves his residence in Bethlehem of Judah and seeks work wherever he can find it. The narrative thrice mentions that the Levite comes from Bethlehem in Judah, and twice acknowledges his rather opportunistic, mercenary sojourning (לגור באשר ימצא/אמצא) 17:8,9) scenario clearly not in accordance with Joshua 21. His opportunism leads to the establishment of a separate Northern shrine in Dan (18:27-30). 
The polemic against the Danite shrine likely reflects the Deuteronomist's perception of Jeroboam's golden calves at Dan and Bethel (1 Kgs 12:28-33). ${ }^{45}$ The golden calves are intended to service the cultic needs of the northern and southern extremes of the Northern Kingdom, eliminating the necessity of Israelite pilgrimages to Judah (1 Kgs 12:26-27). In Judges 17-18, the downward slide begins with the fashioning of an idol in the Ephraimite hill country (where Bethel is located; cf. Jdg 4:5), continues with a fugitive priest from Judah, and ends with the establishment of a shrine at Dan.

\subsubsection{Civil War against Benjamin (Jdg 19-21)}

The civil war against Benjamin at the close of the book of Judges (Jdg 19-21) is fraught with moral and political complexity. The violent rape committed by the men of Gibeah (19) prompts all Israel, led by Judah (20:18; cf 1:2), to battle recalcitrant Benjamin (with its seven hundred ambidextrous slingshot fighters: 20:16). Benjamin's fate is lamented (21:1-3) and then "creatively" remedied through violence and rape $(21: 12,23)$.

Constituents of the five major Israelite tribes play roles in these three episodes. The narrative begins with a Levite, who (like Jonathan son of Gershom in the previous two chapters) lives in Ephraim. Phinehas the high priest, grandson of Aaron, inquires of YHWH on behalf of the people at Bethel before the Ark (20:28).

Gibeah of Benjamin is the site of the shocking, horrifying rape and murder of the concubine. The recapitulation of the story of Sodom (Gen 19) demonstrates the extent of Israel's moral decline; the fact that the Levite turns aside from the Canaanites at Jebus/Jerusalem only to meet such "hospitality" in an Israelite town further underscores the point. The narrative makes explicit that the perpetrators are Benjaminites, not Canaanites in their midst (19:16). The tribe of Benjamin later defends the Gibeahite men and implicitly their actions (20:12-17), thus precipitating the attack by the Judah-led coalition. The ambidexterity of the seven hundred fighters makes the tribe (of "Righthand Son," no less) appear even more deviant. ${ }^{46}$

Judah is designated by YHWH as the leader of the eleven tribes in the attack on Benjamin (20:18), but no judge is named. The only Judahite individual in the narrative is the concubine's father (19:2-9).

The unnamed Levite lives in Ephraim — a situation which, as demonstrated in Judges 17-18, is somewhat dubious from the storymaker's perspective. The Levite's host in Gibeah is also from Ephraim (19:16) — his true hospitality is marred by his (stated) willingness to offer his own daughter and the Levite's concubine to be raped instead of his male guest.

\footnotetext{
${ }^{45}$ See Butler, Judges, 379.

${ }^{46}$ See the discussion of Ehud's left-handedness above (\$5.3.3).
} 
Jabesh-gilead of Transjordan Manasseh appears in the narrative as the lone city who did not join the attack on Benjamin. As a consequence, the Israelites prosecute a herem war on Jabeshgilead, killing all the women and children except the virgin girls as slave-wives for the Benjaminites (21:8-14).

Geographically, much of the narrative is set in Benjaminite territory. After the concubine flees Ephraim, there is reconciliation and rejoicing in Judahite Bethlehem. After the shocking rape and murder in Gibeah, the Levite sends out from his Ephraimite home the gruesome symbol with his message calling Israel to action. "All the sons of Israel," Dan to Beersheba-including Gileadassemble at Mizpah to call Benjamin to give up the Gibeahite perpetrators (20:1-13). The three battles presumably are fought somewhere between Gibeah and Bethel or between Gibeah and Mizpah—within Benjaminite territory in either case. ${ }^{47}$ Defeated Benjamin is lamented in Bethel (21:2). The violent "solutions" devised by Israel to repopulate Benjamin are carried out in Josephite territory: Jabesh-gilead and Shiloh.

Though it is difficult to discern a positive portrayal of any tribe or individual in Judges 1921, Judah is presented as leader in Israel. Benjamin is a wayward but essential constituent of "all Israel," and provision is made for Benjamin's reincorporation. More important than the portrait of any individual tribe, however, is the statement at the beginning and ending of the story: "There was no king in Israel" $(19: 1 ; 21: 25)$. Without a righteous king, Israel has become worse than Sodom: prosecuting a herem war against one of its own tribes, and resorting to extermination and rape to remedy the consequences of rape and attempted extermination. The pro-monarchic message is strong, and the portrait of Benjamin casts aspersion on Saul as a candidate.

Numerous connections between the Civil War narrative and later Saul and David narratives have been observed. First, Judges 20 consists of a conflict between a Judah-led coalition and Benjaminite Gibeah-Saul's hometown (1 Sam 10:26).

Second, Judges 19:29 recounts "the spreading of information by means of a dismembered body." 48 Saul later uses a dismembered pair of oxen to gather all Israel to him in defense of Jabeshgilead (1 Sam 11:7). When Saul is killed, the Philistines decapitate his corpse and send his head and his weapons to "spread the good news throughout the land" (בארץ־פלשתים סביב לבשר; 1 Sam 31:9).

\footnotetext{
${ }^{47}$ The battle narrative may contain echoes of the defeat and victory at Ai (Josh 7-8). Israel does not anticipate defeat, but later successfully executes an elaborate third attack on Benjamin, complete with deflection and ambush (Jdg 20:29-48). The similarities underscore the tragic situation: one of the tribes of Israel is being exterminated like a Canaanite people.

${ }^{48}$ Yairah Amit, "The Saul Polemic in the Persian Period," in Judah and the Judeans in the Persian Period (ed. Oded Lipschits and Manfred Oeming; Winona Lake, IN: Eisenbrauns, 2006), 648.
} 
Third, Judges 21:8-14 may serve to explain Saul's connection to Jabesh-gilead. According to the text, all subsequent Benjaminites would be descendants of either the four hundred virgins of Jabesh-gilead or the two hundred virgins of Shiloh. Schneider suggests, "Saul's extreme anger over the treatment of the residents of Jabesh-Gilead [sic] could easily be rooted in the fact that an ancestress of his was kidnaped [sic] from Jabesh-Gilead." 49 Saul's loyalty is later rewarded by the men of Jabesh-gilead, who rescue the bodies of Saul and his sons and bury them in Jabesh (1 Sam $31: 11-13)^{50}$

Finally, Israel's vow not to give their daughters to Benjamin as wives places the survival of the tribe in jeopardy (Jdg 21:1-3, 18, 22). Similarly, Saul's rash vow endangers Jonathan's life, and Saul breaks the vow in the face of popular sentiment (1 Sam 14:24-30, 38-45).

Given the Judah-Benjamin (David-Saul) conflict embedded in this narrative, scholars debate when exactly to date the story's final form. Blenkinsopp suggests that the Babylonian period or early Persian period would be the most likely fit for Judges 19-21, based on parallels with other biblical narratives from these periods and the prominence of Bethel and Mizpah within the story. ${ }^{51}$

\subsubsection{Summary}

Like the book of Joshua, Judges appears to incorporate both Northern and Southern sources. Even though the middle of the book consists of a core focused on Northern heroes, the shape of the book's final form is pro-Judah, demonstrated in YHWH's designation of Judah as the leading tribe $(1: 2 ; 20: 18)$, in the ideal judge (3:7-11), and in its pro-monarchic outlook and refrain (17:6; 18:1; $19: 1 ; 21: 25)$. The editor/redactor highlights the key character flaws and mistakes that prevent the exploits and reforms of the Northern judges from having lasting impact on Israel.

Between the Northern tragic-heroes and the stylized Judahite ideal-literarily and geographically_is Benjamin: crafty, deviant, ambiguous, ambidextrous. Upon closer examination, Benjamin and its hero are not really any more deficient than the Northern tribes and their heroesbut the proximity to Judah accentuates Benjamin's inadequacy. Judah, though perhaps portrayed in a slightly better light than the other tribes, does not go untainted in the matters of the conquest (Jdg 1) and in the civil war (Jdg 20-21). The rhetoric of Judges in its final form is pro-monarchic, and also- through the use of geography, intertextual echoes, and literary motifs-pro-David and antiSaul.

${ }^{49}$ Schneider, Judges, 283-284.

${ }^{50}$ Amit argues that the Chronicler, as part of a later Saul polemic, alters the story to diminish the heroism of this act; "Saul Polemic," 650.

${ }^{51}$ Joseph Blenkinsopp, "Benjamin Traditions Read in the Early Persian Period," in Judah and the Judeans in the Persian Period (ed. Oded Lipschits and Manfred Oeming; Winona Lake, IN: Eisenbrauns, 2006), 642-643. 


\subsection{THE BOOK OF SAMUEL ${ }^{52}$}

The book of Samuel follows the rise and establishment of the first two kings of Israel, who are closely tied to one another by marriage. Since the first of these kings is a Benjaminite, it is natural that Benjaminite persons and places would be featured prominently in the narrative.

\subsubsection{Benjaminite Places}

A significant portion of the book of Samuel is set within Benjaminite territory, including two-thirds of Samuel's regular ministry circuit (Bethel, Gilgal, Mizpah; 1 Sam 7:16), Gibeah, Saul's hometown and seat of power (1 Sam 10:26;11:4; 14:2; 15:34; 22:6;26:1), and Jerusalem, David's capital for most of his reign (2 Sam 5:6-10).

Samuel is born in and resides in Ramah, which is understood in 1 Samuel as being part of Ephraim, not Benjamin (1:1; contra Josh 18:25). When David first flees from before Saul, he goes to Samuel at Ramah (19:18-20:1).

Mizpah is a crucial administrative and cultic city during the judgeship of Samuel (1 Sam 7:5-17), and is the site of the choosing of Saul as king by lot (1 Sam 10:17-25).

Much of Saul's first war with the Philistines in 1 Samuel 13:1-14:46 takes place within Benjaminite towns: Geba (13:3, 16), Beth-aven (13:5; 14:23), Ophrah (13:17), and Gibeah (14:2) are mentioned, as well as other towns to the immediate north and south of Benjamin.

On his second flight from Saul, David passes through Nob, apparently a Levitical/priestly city within Benjamin (1 Sam 21:1-9). ${ }^{53}$ Saul later orders the slaughter of the priests at Nob (1 Sam 22:9-23).

After the death of Saul and Jonathan, Abner crowns Ishbosheth/Eshbaal "king over Gilead, over the Ashurites, over Jezreel, over Ephraim, and over Benjamin, even over all Israel” (2 Sam 2:9). David rules Judah from Hebron (2:10-11). The subsequent war of succession takes place in and around Gibeon (2:12-28). The conclusion of the struggle for the throne occurs when two Benjaminites from Beeroth assassinate Ishbosheth in his own house, presumably in Gibeah of Saul $(4: 5-7)$.

\footnotetext{
52 The following section incorporates material from my unpublished paper, "Sleeping Dogs: Benjamin-Judah Relations in the Persian Period and the Chronicler's Portrait of Saul," presented at the Mid-Atlantic Regional meeting of the Society of Biblical Literature in Baltimore, MD, in March 2013. I am grateful to the conference participants for their constructive feedback.

${ }^{53}$ Neh 11:32; see also Isa 10:32. McKenzie places Nob between Gibeah and Jerusalem: "1 and 2 Samuel," in The New Oxford Annotated Bible (NOAB), Michael D. Coogan, ed. (New York: Oxford University Press, 2007 ), 433.
} 
From the conquest of Jerusalem (2 Sam 5:6-10) onward, David's seat of power is in Jerusalem, which notably belongs to both Judah and Benjamin (Josh 15:63; 18:28). Many of the events described in 2 Samuel 5-24 take place in or around Jerusalem. David's first achievement as king of all Israel is to take from the Jebusites this city which is crucial in the Deuteronomistic narrative as the future location of the temple.

In David's first Philistine war as king, he strikes down the Philistines "from Geba as far as Gezer" (2 Sam 5:25). The initial stage of the Sheba rebellion takes place partly in Gibeon (2 Sam 20:8).

In 2 Samuel 21:1-14, the Gibeonites are permitted to hang Saul's grandsons; Saul and Jonathan's bones are retrieved from Jabesh-gilead and buried with Kish and the grandsons "in Benjamin" (21:14).

In the narrative of David's census (2 Sam 24), the angel of YHWH halts at Araunah's threshing floor in Jebus, which is on the Benjamin-Judah border, and which later becomes the temple site. ${ }^{54}$

In summary, Benjaminite territory once again lies at the geographical and literary center of the Deuteronomistic narrative. Even though Ramah, the hometown and seat of Samuel, appears to be Ephraimite at this stage, much of Samuel's activity occurs within Benjamin. Saul's capital is Benjaminite, and David's capital lies on the Benjamin-Judah border. As a character analysis will show, the interplay between these two tribes-usually within the tribal borders-dominates the narrative of the book of Samuel.

\subsubsection{Major Characters in Relation to Benjamin}

The book of Samuel largely follows the public lives of four major characters: Eli, Samuel, Saul and David. One important narrative motif within 1 Samuel is the "abnormal," non-paternal succession of leadership among these four leaders who are unrelated to one another by blood. ${ }^{55}$ Jobling observes a pattern concerning the relationships between these four figures: "The leader has

${ }^{54}$ See the discussion in Louis C. Jonker, “Of Jebus, Jerusalem and Benjamin: The Chronicler's Sondergut in 1 Chronicles 21 Against the Background of the Late Persian Era in Yehud," in Chronicling the Chronicler: The Book of Chronicles and Early Second Temple Historiography (ed. Tyler F. Williams and Paul S. Evans; Winona Lake, IN: Eisenbrauns, 2013), 81-102; and Yairah Amit, “Araunah's Threshing Floor: A Lesson in Shaping Historical Memory," in What Was Authoritative for Chronicles? (ed. Ehud Ben Zvi \& Diana Edelman; Winona Lake, IN: Eisenbrauns, 2011), 133-144.

${ }^{55}$ In fact, it appears that the four figures come from different tribes, the four major tribes of Israel: Eli from Levi (he and his sons were priests in Shiloh, and his son, Phinehas, is named after Aaron's grandson; 1 Sam 1-4), Samuel from Ephraim (1 Sam 1:1; contra 1 Chr 6:28-38—-see discussion below), Saul from Benjamin, and David from Judah. 
natural sons who play a significant role in the story, but he adopts the next leader as a surrogate son. This surrogate son has (obviously) a natural father who plays some role, though a subordinate one, in the story." ${ }^{\circ 6}$ The author/editor provides an account and assessment of each figure's public life and character, in order to explain why the first three leaders were unable to establish a blood dynasty.

The most important of these assessments are those of Saul and David, who are compared explicitly and allusively throughout the narrative. 1 Samuel 10-31 covers Saul's reign, and 2 Samuel, David's reign. Given the Benjaminite identity of Israel's first king and the second king's close relationship to Benjamin, one would expect that a Benjaminite audience of the book of Samuel in the Babylonian or Persian periods would pay close attention to the characterization of these two leaders.

\subsubsection{Eli}

Eli and his sons, Hophni and Phinehas, serve as priests of YHWH at Shiloh (1 Sam 1:3). Though their tribal identity is not stated explicitly, they appear to be Levites (cf. 1 Sam 14:3; $1 \mathrm{Kgs}$ 2:27 $7^{57}$ ); Phinehas shares the name of Aaron's grandson, a revered high priest (Num 25). Eli is portrayed as devout, but his sons are corrupt and steal from YHWH's portion of the sacrifices (1 Sam 2:12-17). Eli judges Israel forty years, and is succeeded by Samuel (1 Sam 4:18).

The lone reference to Benjamin in the Eli narratives (1 Sam 1-4) is the Benjaminite messenger who returns in mourning from the Philistine battle, bearing news that the ark has been taken and Eli's sons have been killed (1 Sam 4:12-18). The man's Benjaminite identity does not appear to be anything more than a detail designed to lend historical credibility to the narrative; nothing about the characterization is positive or negative, nor is the detail particularly relevant to the story's meaning.

\subsubsection{Samuel}

Samuel—not surprisingly—is a significant character in the book of the Hebrew Bible that bears his name. Samuel is the last of the great judges of Israel (1 Sam 7:15-8:3); he has a miraculous birth narrative that links him with Samson, as well as with ancient patriarchs born of barren women (Isaac, Jacob, Joseph and Benjamin, etc.).

${ }^{56}$ David Jobling, 1 Samuel (Berit Olam; Collegeville, MN: Liturgical Press, 1998), 112.

${ }^{57}$ Rendsburg accepts the connection with Ahitub, a "legitimate priest" according to $1 \mathrm{Chr} 6$, as further evidence that Eli, Hophni and Phinehas are Levites—but argues that Samuel and Zadok are non-Levites grafted into the genealogies of $1 \mathrm{Chr}$ 6; see Gary A. Rendsburg, "The Internal Consistency and Historical Reliability of the Biblical Genealogies," VT 40 (1990): 197n25. 
Samuel's relevance to Benjamin is found in three features of his character and activities: he is Ephraimite who legitimates and crowns a Benjaminite king; he is a religious leader who prophesies the transfer of the throne from a Benjaminite to a Judahite; and he conducts a significant portion of his judicial and cultic leadership within Benjaminite territory.

The harmonization problem of Samuel's tribal identity_Ephraimite according to the DtrH (1 Sam 1:1, 19; 2:11 ${ }^{58}$ ), but Levite according to Chronicles (1 Chr 6:25-35)—should be understood as the Chronicler "grafting" Samuel into the line of Levi in order to legitimize his cultic activities. ${ }^{59}$ With regard to the Deuteronomist's characterization of Samuel, there is little question that he is an Ephraimite (1 Sam 1:1). ${ }^{60}$ At least two intertextual echoes link Hannah with Rachel, mother of the Josephite tribes, further cementing Samuel's connection to Ephraim. ${ }^{61}$

Given the ties between Joseph and Benjamin in both tradition and geography, it is not surprising that Samuel judges primarily in Ephraim and Benjamin, or that he presides over the selection of a Benjaminite king. It has been suggested that Samuel's birth narrative was actually adapted from a narrative of Saul's birth, because the root of Saul's name (שאל) matches the puzzling etymology of Samuel's name: "She gave birth to a son; and she named him Samuel (שמואל), saying, 'Because from YHWH I asked for him (שאלתיו)" (1 Sam 1:20b). ${ }^{62}$ But, as discussed in the previous chapter of this study $(\S 4.3 .1)$, this explanation is not necessary to understand the link between the usage of שאל in the Samuel narratives; rather, Samuel is the prophet/judge who anoints Saul and legitimates his rule. ${ }^{63}$

${ }^{58}$ By this time, Ramah is an Ephraimite city (Jdg 4:5).

${ }^{59}$ Rendsburg, "Biblical Genealogies,” 195-196.

${ }^{60}$ Lest it be thought that Elkanah, Samuel's father, is a Levite residing in Ephraim, the text explicitly calls his ancestor an Ephraimite (אפרת; 1:1). Leuchter observes that during this period non-Levites could function as Levites in judicial and priestly capacities, and calls Samuel "an archetypical Levite”; see Mark Leuchter, “The Levite in Your Gates': The Deuteronomic Redefinition of Levitical Authority,” JBL 126 (2007): 423, 426.

${ }^{61}$ Hannah, like Rachel, is the favored but barren wife, tormented by a fertile rival. Elkanah "comforts" Hannah with the words, “Am I not better to you than ten sons?” In Ruth 4:15, Naomi’s friends celebrate with her that Ruth, her daughter-in-law, is "better to you than seven sons," foreshadowing the birth of Ruth's most important descendant: David, the eighth son ("better than seven sons"). By use of the phrase, "better than $X$ sons," the author of 1 Sam 1-2 presents Samuel as "better to Hannah than ten sons," just as Joseph is the favored eleventh son of Jacob. Joseph receives the birthright, which entitles him to a double portion in Israel (Gen 48)_just as Hannah receives a double portion from her husband (1 Sam 1:5). These echoes—-the "better than $X$ sons" motif and the favored but barren wifegive the Hannah-Samuel narrative a Rachel-Joseph flavor and cement the (already explicit) tribal identity of Samuel.

${ }^{62}$ See the discussion in Marsha C. White, "Saul and Jonathan in 1 Samuel 1 and 14," in Saul in Story and Tradition (ed. Carl S. Ehrlich and Marsha C. White; FAT 47; Tübingen: Mohr-Siebeck, 2006), 120-124.

${ }^{63}$ White, "Saul and Jonathan in 1 Samuel 1 and 14," 126-127; Steven L. McKenzie, "Saul in the Deuteronomistic History," in Saul in Story and Tradition, 59-60. 
If indeed parts of 1 Samuel 1-14 once formed the core of a coherent narrative of Saul's rise-a plausible scenario ${ }^{64}$ - then Samuel's positive link to Saul and his activities within the Benjaminite sphere (especially Mizpah and Bethel) make perfect sense. An Ephraimite judge's choice of a Benjaminite king is good politics: defensible given Benjamin's geography at the center of Israel, and savvy given the historic connections between the tribes.

But the final form of the book of Samuel is pro-David, though both positive and negative elements of Saul's and David's lives and careers are retained. In the received text, Samuel is responsible for David's kingship also. The Ephraimite judge/prophet thus symbolizes YHWH's election and epitomizes the "correct" choice for later Israel: a Benjaminite candidate selected, but later rejected and replaced by a Judahite.

\subsubsection{Saul}

Saul, as noted in the previous chapter, is perhaps the most prominent Benjaminite in the Bible. A good portion of the interpretive survey to this point has sought to relate narrative texts to later concerns about Saul and his kingship. Much of the scholarly work that links Benjamin texts to later Babylonian- and Persian-era concerns does so through the interpretive lens of Saul and Saulide-Davidide rivalry, as we have seen previously. In this section, the narrow concern is the characterization of Saul within the book of Samuel, and the way in which that characterization might reflect the tribal context of the author/editor.

Several kinds of perspectives have been offered concerning the Deuteronomist's characterization of Saul. It has been observed that Saul fits the "tragic hero" motif prevalent in Greek literature. ${ }^{65}$ The inclusion of both Saul's successes and his failures makes him a complex figure with whom the audience can empathize. ${ }^{66}$ Others observe that Saul's failures outweigh and reverse his successes within the narrative, an imbalance that is accentuated by the ubiquitous comparison with David's many successes during Saul's reign. ${ }^{67}$

Each perspective on Saul's characterization_- "tragic hero," "balanced portrait," and "mere foil for David" - has merit. The difficulty of reconciling these helpful approaches dissolves if the book of 1 Samuel is understood as a composite work that incorporates a previously-independent

${ }^{64}$ White, "Saul and Jonathan in 1 Samuel 1 and 14"; Gregory Mobley, "Glimpses of the Heroic Saul," in Saul in Story and Tradition, 80. It is usually argued that 1 Sam 9-14 formed the core of this Saul narrative. White points out the connections between 1 Sam 1-2 and Saul-Jonathan, so perhaps some earlier version of 1 Sam 1-14 formed an original narrative of Saul's anointing prophet, Saul's rise, and Saul's success.

${ }^{65}$ Yairah Amit, "The Delicate Balance in the Image of Saul and Its Place in the Deuteronomistic History," in Saul in Story and Tradition, 71-74. Amit points to Northrop Frye and Gerhard von Rad as proponents of this view.

${ }^{66}$ Amit, "The Delicate Balance in the Image of Saul," 73.

${ }^{67}$ McKenzie, "Saul in the Deuteronomistic History," 59-70. 
pro-Saul narrative into a larger, pro-David narrative. ${ }^{68}$ The transformation from a pro-Saul narrative into the present pro-David form explains numerous characterizations of Saul that could be understood initially as positive but turn out to be negative-a few examples will suffice. Saul, like many heroes, possesses a signature weapon: a spear (1 Sam 13:22; 18:10; 19:9; 20:33; 22:6; 26:7, 11, 12, 16, 22; 2 Sam 1:6)—but this symbol of his heroism is negated by David's defeat of Goliath after refusing Saul's weapons and armor (1 Sam 17:38-40, 47-51). ${ }^{69}$ The positive origin of the expression, "Saul among the prophets," found in 1 Samuel 10:10-12 is replaced with a negative origin story in 19:23-24. ${ }^{70}$ Saul's vow/curse upon any soldier who ate food (1 Sam 14:24) and his subsequent willingness to realize that curse even on his own son $(14: 44)$ could be understood as an act of extreme piety on par with that of Abraham which is rewarded with success in battle. ${ }^{71}$ But in the narrative's final form, Saul's curse is construed as a rash oath that nearly brings calamity upon his house, just as Jephthah did. ${ }^{72}$

Thus, the portrait of Saul in the received text is a mixture of positives and negatives, a mixture which-like the portrait of the Benjaminite and Josephite judges in the book of Judgesmay be attributed to the introduction of the editor's perspective into an originally positive portrait.

As has been noted, the book of Samuel is concerned to explain the "abnormal" (nonpaternal) succession of the first four leaders in the narrative. The most important of these successions for the Deuteronomist is David's accession to the throne of Israel in place of Saul's heirs. This has two key implications for a reconstruction of the Deuteronomist's context and audience. First, such a work might have been necessitated by a renewed conflict between the descendants of David and Saul. ${ }^{73}$ Second, the Deuteronomist's adaptation of a previously pro-Saul narrative into his larger pro-David narrative reflects a desire to lend credibility to his own work, and to co-opt his opponents' narrative. What better way to prove the legitimacy of the Davidic line than through the skillful editing of a Saulide story?

${ }^{68}$ White, "Saul and Jonathan in 1 Samuel 1 and 14," 119-120, 135-136; Mobley, "Glimpses of the Heroic Saul," 80. Daniel E. Fleming suggests that David's lament in 2 Sam 1:19-27 also may have originated in a pro-Saul circle and subsequently been attributed to David (The Legacy of Israel in Judah's Bible: History, Politics, and the Reinscribing of Tradition [New York: Cambridge University Press, 2012], 151).

${ }^{69}$ Mobley, "Glimpses of the Heroic Saul," 83-84.

${ }^{70}$ Mobley, "Glimpses of the Heroic Saul," 85; McKenzie, "Saul in the Deuteronomistic History,” 60n9, 65.

${ }^{71}$ White, "Saul and Jonathan in 1 Samuel 1 and 14," 128-135.

${ }^{72}$ McKenzie, "Saul in the Deuteronomistic History," 62.

${ }^{73}$ Diana V. Edelman, "Did Saulide-Davidic Rivalry Resurface in Early Persian Yehud?” in The Land That I Will Show You: Essays on the History and Archaeology of the Ancient Near East in Honour of J. Maxwell Miller (ed. J. Andrew Dearman and M. Patrick Graham; Sheffield: Sheffield Academic Press, 2001), 90. 
The characterization of Saul in the book of Samuel is intended to reflect poorly upon the viability of Benjaminite leadership in Israel, when compared with Judahite leadership. Just as Ehud initially appears somewhat successful but pales when compared to Othniel, Saul is a marginally successful prince of Israel who nevertheless ends up lacking all the most important qualities for kingship—qualities attributed to David. Such an anti-Benjamin-leadership message could have been relevant at several different stages in Judah's history: 1) in the later stages of the monarchy, when the kings of Judah expanded their territory north, and Northern and Benjaminite refugees came south after the destruction of the Samarian kingdom; 2) in the Babylonian period, during which a Benjaminite governor ruled Yehud from Mizpah; or 3) during the early Persian period, when primarily Benjaminite she'erit and primarily Judahite golah communities vied for leadership in Yehud. ${ }^{74}$ If indeed the book of Samuel incorporates a pro-Saul narrative, then the late-monarchic integration of Benjaminite territory and refugees could have brought the Saul narrative south to Judah at that time, making a Babylonian- or Persian-era incorporation of the narrative into the DtrH more likely.

\subsubsection{David}

David is one of the most significant figures in the history of biblical interpretation. In modern biblical scholarship, the traditional interpretation of the pious "man after God's own heart" has given way to a variety of "bad David" studies. ${ }^{75}$ Characterizations of David can be understood on a three-dimensional spectrum. The first dimension relates to the historical reliability of the Deuteronomistic narratives and the degree of bias introduced by the author/editor-what is the "real story" reflected within the text? The second dimension is the degree of literary integrity and coherence of the narratives-is David's characterization consistent and coherent throughout the story? The third dimension evaluates David's character and behavior as reflected in and behind the text—perfectly pious, or murderously Machiavellian? ${ }^{76}$

As discussed above, this study assumes that the book of Samuel incorporates a pro-Saul narrative into a larger pro-David narrative. It does not follow, however, that the final form of the David narrative lacks literary integrity. Scholars have observed, for example, a high degree of coherence in the so-called "Succession Narrative" of 2 Samuel 9 through 1 Kings 2.

${ }^{74}$ Edelman, "Saulide-Davidic Rivalry," 86-91. Edelmen argues that an early Persian date for the final form is most likely.

${ }^{75}$ A few examples include: Robert Polzin, David and the Deuteronomist: 2 Samuel (Bloomington, IN: Indiana University Press, 1993); Baruch Halpern, David's Secret Demons: Messiah, Murderer, Traitor, King (Grand Rapids: Eerdmans, 2001); Steven L. McKenzie, King David: A Biography (New York: Oxford University Press, 2000).

${ }^{76}$ Paul Borgman, David, Saul, and God: Rediscovering an Ancient Story (New York: Oxford University Press, 2008), 11-16. 
Regarding the subject at hand, David is consistently presented as a complex character throughout the book of Samuel. This characterization includes damaging accounts of sacrilege (1 Sam 21:4-6); alliance with the Philistines against Israel (1 Sam 27:1-28:2—but compare 29:1-11); civil war of usurpation (2 Sam 2-4); adultery and murder (2 Sam 11-12); and slaughter of rivals (2 Sam 21:1-14; 1 Kgs 2:8-9).

The Deuteronomistic editor takes every opportunity to present David's behavior in the best possible light, but in his final assessment, David's kingship is YHWH's doing, not David's (1 Sam 16; 2 Sam 7). For the Deuteronomist, the notion of YHWH's eternal covenant with David dominates the narrative - and though election does not expiate David's sins, it does eliminate (or at least mitigate) his culpability for the removal of Saul's line from the kingship. In the author's view, David's dealings with Saul and his family are unimpeachable and require no apology.

Such an approach—while satisfying a pro-David audience-leaves much fodder in the narrative for anti-Davidic partisans. Knoppers observes that the Deuteronomist's accounts of David's dealings with Saul "would provide Benjaminite readers with plenty of ammunition to claim that their most famous ancestor and his house were treated poorly by Judah's hero.",77

Yet the Deuteronomist's David is also presented favorably in his dealings with various Benjaminites, which are expounded in greater detail in the next subsection. David foregoes two opportunities to kill Saul, refusing to lay a hand on YHWH's anointed (1 Sam 24, 26). David laments Saul and Jonathan (2 Sam 1:17-27), kills the Amalekite who claims to have ended Saul's life (2 Sam 1:2-16), and blesses the men of Jabesh-gilead for their courageous act of faithfulness toward Saul in his death (2 Sam 2:4-6). David even receives some early Benjaminite support in his quest to become king, though Benjaminite support is not as early or as unanimous as the Chronicler suggests (1 Sam 22:7-8). When David conquers the Amalekites (contrasting with Saul's failure to kill King Agag; 1 Sam 15), he sends portions of the spoil "to the elders of Judah, his friends" ( לזקני יהודה לרעהו), ${ }^{78}$ but includes Bethel, an historically Benjaminite city (1 Sam 30:26-31).

One of David's key strengths is his ability to attract support from outside Judah, including Benjaminites, members of the Northern tribes, and even foreigners. The list of David's mighty men includes members of various tribes of Israel and non-Israelite peoples. The ethnically inclusive list of David's “Three" and "Thirty” is evidence of David's early support from "all Israel," and even resident aliens within Israel. Among David's mighty men is a warrior of Saul's own people and

${ }^{77}$ Gary N. Knoppers, "Israel's First King and 'the Kingdom of YHWH in the hands of the sons of David': The Place of the Saulide Monarchy in the Chronicler's Historiography," in Saul in Story and Tradition, 209.

${ }^{78}$ McKenzie, “1 and 2 Samuel,” 445. 
hometown, "Ittai son of Ribai of Gibeah of the Benjaminites" (2 Sam 23:29), ${ }^{79}$ as well as Abiezer the Anathothite (23:27). Barzillai the Gileadite-Manassite—is one of David's key supporters in the Absalom crisis (2 Sam 19:31-39), despite the fact that some of the elders of Judah had capitulated to Absalom (2 Sam 19:11-15).

David is repeatedly able to unite all Israel behind him in battle—something Saul fails to do. After the brief war with the forces of Mephibosheth, all Israel unites under David at Hebron (2 Sam 5:1-3). David's first act as king of all Israel is to take Jerusalem from the Jebusites (2 Sam 5:4-9), a task Judah and Benjamin had failed to complete (Josh 15:63, Jdg 1:21).

For the Deuteronomist, the greatest point of contrast between David and Saul is that David seeks YHWH's guidance and Saul does not. Saul commits two cultic violations (1 Sam 13; 15), makes a rash oath and breaks it (1 Sam 14), and later consults a medium (1 Sam 28). David repeatedly inquires of YHWH, particularly in matters of battle and strategy, and he is rewarded with victory (1 Sam 23:2-5; 30:8; 2 Sam 2:1-2; 5:19-25).

David's first achievement as king of all Israel is perhaps his most religiously significant: the conquest of Jerusalem (2 Sam 5:6-10), the future temple site, crucial in Deuteronomistic thought. This action has indirect negative and positive implications for Benjamin. To the extent that Benjamin had failed to take Jerusalem from the Jebusites (Jdg 1:21), David's success reflects poorly on Benjamin. However, the situation of the future temple site on the border between Benjamin and Judah becomes a recommending feature of the Jerusalem cult center. For the Deuteronomist, David has finally accomplished the conquest mandate (Deut 7:1-16) and prepared the way for YHWH to "set His name to dwell" in a house of His own choosing (Deut 12:11).

The message of the Deuteronomistic account of David for later intertribal relations is the legitimation of Jerusalem as the temple site, and of Judah and the line of David as YHWH's chosen leadership in Israel—despite the fact that David (nor his descendants) were perfect. It is doubtful that the message of David's election would have "won over" a Benjaminite audience, but it may have been intended to galvanize internal Judahite support for Davidide leadership in the exile or postexile, or to muster support from the Persian court for such leadership. ${ }^{80}$

\subsubsection{Lesser Benjaminite Characters}

Numerous Benjaminite characters form the supporting cast in the Deuteronomist's narratives of Saul and David. A brief survey of their characterization will focus on their dealings

79 This "Ittai" does not appear to be the same person as "Ittai the Gittite" (אתי הגתי), one of David's commanders and loyal supporters during the Absalom crisis (2 Sam 15:19-22; 18:2-5). That Ittai is noted by David for his loyalty despite his status as a foreigner (15:19-20).

${ }^{80}$ Edelman, "Saulide-Davidic Rivalry," 75. 
with David, and conclude with an evaluation of David's relation to Benjamin overall and its significance for later audiences.

\subsubsection{Jonathan}

Jonathan, son of Saul and friend to David, is presented very favorably in the book of Samuel. No doubt both a hypothesized pro-Saul source and the final editorial flourish of the DtrH would have wanted to portray Jonathan positively. Jonathan is first mentioned in Samuel as a successful military leader in his own right, not primarily as Saul's son (1 Sam 13:2, 3, 16). He exhibits tremendous courage (14:6-14) and perhaps greater common sense than his father (14:2730). He fits the Benjaminite stereotype of a skilled archer (20:20-22, 35-40).

Jonathan represents in 1 Samuel an ideal Benjaminite in the author's view. Rather than claiming his father's throne, he acknowledges a Judahite as YHWH's anointed, makes a covenant with him, and supports him at great risk to his own life (18:1-4; 19:1-3; 20:1-42). Jonathan hopes to sit at David's right hand when David succeeds Saul (23:16-18). David reciprocates Jonathan's loyalty by lamenting his death (2 Sam 1) and showing mercy to his son (2 Sam 9).

\subsubsection{Michal}

Michal, daughter of Saul and wife to David, receives a mixed portrayal in the book of Samuel. Michal is introduced as something of a pawn in political dealings between Saul and David. Her older sister is promised to David as a wife, but passed over for reasons not entirely clear (1 Sam 18:17-19). Michal loves David, though nothing is said of David's love for her (18:20). At the time of their betrothal, Saul hopes to get David killed by requiring Philistine foreskins as a dowry, but David is doubly successful in this mission (18:25-29). Michal later becomes an active participant in the struggle on David's side, rescuing him from her father (19:11-17).

Michal once again recedes into a passive role as she is given to "Palti son of Laish" while David is hiding from Saul (1 Sam 25:44). Her return to David's possession is one of the conditions of peace negotiated after the war of succession (2 Sam 3:13-16). Michal later despises and rebukes David for unseemly behavior in the Ark processional, actions for which she is punished with barrenness (2 Sam 6:16, 20-23). ${ }^{81}$

${ }^{81}$ Michal also appears in the MT in 2 Sam 21:8b (ואת־חמשת בני מיכל בת־שאול אשר ילדה לעדריאל בן־ברזלי המחלתי);

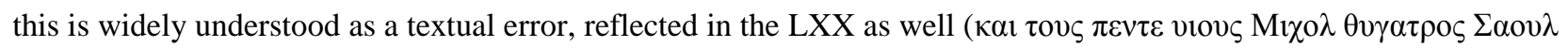

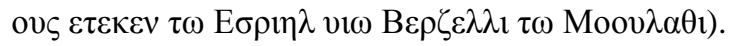

McCarter explains, "MT has mykl, 'Michal,' but we know that Michal was childless (6:23) and that Adri(el) was Merob's husband (1 Sam 18:19). $\mathrm{LXX}^{\mathrm{LN}}$ (merob) and $\mathrm{MT}^{\mathrm{MSS}}$, therefore, are correct in reading $m r b$, 'Merob' (cf. $\mathrm{LXX}^{\mathrm{M}}$, Syr., Targ.). LXX ${ }^{\mathrm{B}}$ agrees with MT, but the fact that it renders mykl as michal instead of the usual LXX melchol 
Michal is portrayed positively insofar as she loves and protects David. Her unfortunate marriage to Palti weakens her connection to David, though he is still attached to her. But her later actions in the Ark narrative eliminate the possibility of lasting association with David: she would never bear him children and (perhaps) provide a link between the two houses that could legitimize David's heirs in the eyes of later Benjaminites.

\subsubsection{Ishbosheth}

The characterization of Ishbosheth, son of Saul and rival to David, is negative in many respects. His reign is a mere two years, and he rules a smaller kingdom than that of his fatherJudah follows David (2 Sam 2:9-10), and Saul had lost several Israelite cities to the Philistines in his death (1 Sam 31:7).

Ishbosheth is portrayed as weak and impotent. He is little more than a puppet of Abner his uncle, who commanded Saul's army (2 Sam 2:8; 3:6). Abner is clearly the military leader, not Ishbosheth (2:12-17). When Abner and Ishbosheth have a falling out over a royal concubine, Abner transfers his allegiance to David (3:7-11). Ishbosheth cannot withhold from David Michal his wife (3:14-16). Ishbosheth is assassinated by his two captains, Rechab and Baanah (4:2-8).

Nevertheless, Ishbosheth is called "a righteous man" by David, who executes and displays Ishbosheth's killers (4:9-12). Ishbosheth's shortcomings are his inadequacy as king and his failure to acknowledge David's rightful rule. David's avenging Ishbosheth's death and his earlier acceptance of Abner are indicative of his willingness to make peace with Benjaminite leadersprovided that they acknowledge his kingship.

\subsubsection{Abner}

Abner first appears in the Saul narrative as Saul's captain and uncle (1 Sam 14:50-51; 17:55-57; 20:25). Abner is a minor character in the narrative of David's second opportunity to kill Saul (26:5, 14-15). After Saul's death, Abner makes Ishbosheth king under himself (2 Sam 2:8). After defecting to David, Abner is assassinated by Joab and Abishai (3:27-30).

(3:13, etc.) shows that it is recensional and suggests that merob was in fact the OG rendering. Thus merob cannot have been derived from 1 Sam 18:19, which was lacking in OG” (P. Kyle McCarter, Jr., II Samuel [Anchor Bible Commentary; Garden City, N.Y.: Doubleday, 1984], 439).

Interestingly, Targum Jonathan resolves the difficulty by explaining that Michal raised Merab's five sons ( וית חמשא בני מירב דרביאת מיכל בת שאול דילידת לעדריאל בר ברזלי דממחולת.). 
Abner is presented as a capable military leader (2 Sam 2:12-17 ${ }^{82}$ ), a skilled fighter (2:18$23)$, and at times a sensible diplomat $(2: 25-28 ; 3: 12,17-21)$. Abner fights honorably for his clan and his king, but recognizes David's right to rule and leads "the elders of Israel" and "the whole house of Benjamin" to follow David (3:17-19). He kills Asahel in battle after warning him to stand down (2:20-23), but Asahel is avenged dishonorably by Joab (3:27). David laments Abner's death and pronounces a curse on Joab's house for this betrayal (3:28-39).

Abner, like Jonathan, represents the Deuteronomist's ideal Benjaminite: he supports the "rightful" Judahite king. In exchange, David shows loyalty to Abner by making a covenant with him, and by lamenting and avenging (1 Kgs 2:5-6, 32-34) his death.

\subsubsection{Mephibosheth and Ziba}

Mephibosheth (called Merib-baal in Chronicles) is first mentioned in 2 Samuel 4:4, which explains how he came to be crippled. After his rule is established, David seeks out descendants of Saul in order to show kindness for Jonathan's sake (2 Sam 9:1). Ziba is "a servant in the house of Saul" who brings Mephibosheth out of hiding to David (9:2-6). Both Mephibosheth and Ziba fearfully humble themselves before David, who rewards them with the ownership and care of Saul's former estates (9:8-13). Mephibosheth is always to eat at David's table (9:10,13). When David allows the Gibeonites to avenge themselves on Saul's grandsons, Mephibosheth is excluded because of David's covenant with him and with Jonathan (21:7).

Years later, when David is forced to flee from Absalom, Ziba approaches David and reports to him that Mephibosheth hopes to regain the kingship of Saul for himself. David gives all Mephibosheth's lands over to Ziba (16:1-4). It appears, however, that Ziba has lied, since Mephibosheth welcomes David upon his return (19:24-30). David, bound by his oath, divides the land between the two, but Mephibosheth throws in his lot completely with David, saying, "Let him even take it all, since my lord the king has come safely to his own house" (19:30).

Mephibosheth is honored because of David's allegiance to Jonathan, and is later rewarded for his loyalty to David. Mephibosheth represents the proper relationship between David and Benjamin: honored king and loyal subject.

\subsubsection{Shimei}

Mephibosheth contrasts sharply with Shimei and Sheba, Benjaminites who oppose David. Shimei taunts David in his flight from Absalom, throwing stones at him and calling him a usurper

\footnotetext{
82 Joab's twelve (Judahite) warriors and Abner's twelve (Benjaminte/Northern) warriors fight to a bloody draw-there is no winner.
} 
(2 Sam 16:5-14). Later, Shimei begs for and receives pardon from David when he returns (19:1623)—though David later tells Solomon to kill Shimei after David dies (1 Kgs 2:8-9, 36-46).

Interestingly, when Shimei asks forgiveness, he claims to be from "the house of Joseph" (19:20), though earlier he is "a man of the clan of the house of Saul" (16:5). This is consistent with the historically close affiliation of Benjamin with Ephraim and Manasseh.

When David is on the run from Saul, he calls himself "a dead dog" to highlight his insignificance and humility before Saul (1 Sam 24:14). The stories of Mephibosheth and Shimei share the phrase "dead dog" (הכלב המת): Mephibosheth calls himself "a dead dog" before David (2 Sam 9:8), whereas Abishai calls Shimei "a dead dog" for cursing David (2 Sam 16:9). In these three narratives, the proper stance before YHWH's anointed is humility-David and Mephibosheth share that quality, but Shimei does not.

\subsubsection{Sheba}

As David returns across the Jordan and is hailed by Judah at Gilgal, a rift opens between Judah and Israel over the honor of welcoming the king in his return (2 Sam 19:41-43). "Israel" is said to have "ten shares (עשר־יידות) in the king," anticipating the later rebellion of the "ten" (cf. §4.1.2) Northern tribes against Rehoboam (1 Kgs 12:16). Sensing an opportunity, a Benjaminite named Sheba son of Bichri proclaims a rebellion against David (2 Sam 20:1), and all Israel save for Judah follows Sheba (20:2). "Israel" presumably includes Benjamin, since a Benjaminite leads the rebellion.

Joab, having assassinated Amasa who had replaced him as commander (20:4-12) ${ }^{83}$, pursues Sheba and his forces to Beth-maacah, one of the northernmost fortresses in Israel (20:13-15). Joab negotiates with a leading "wise woman" of the city to execute Sheba and throw his head over the wall (20:16-22).

Sheba's rebellion ends quickly. Like David's previous Benjaminite rivals to the throne (Saul and Ishbosheth), Sheba is beheaded. David is not directly responsible for Sheba's death, just as he was not responsible for the deaths of Saul, Jonathan, Ishbosheth, Abner and Absalom.

\subsubsection{Saul's Grandsons}

Having inquired of YHWH concerning the reason for a three-year famine in the land, David allows the Gibeonites to avenge Saul's betrayal of the Josh 9 covenant on seven of Saul's grandsons (2 Sam 21:1-14). David does not permit the Gibeonites to kill Mephibosheth because of the covenant between David and Jonathan (21:7).

\footnotetext{
${ }^{83}$ A dishonorable act which, incidentally, occurs in Gibeon.
} 
The Deuteronomist paints this action in the best possible light: David responds appropriately to YHWH's action and word, and his covenant-keeping with Mephibosheth contrasts nicely with Saul's covenant-breaking. But it is difficult not to view this action-through Benjaminite eyes-as an attempt to destroy potential Saulide challengers to the throne. ${ }^{84}$ Once again, David's Benjaminite rivals are killed and their corpses mutilated, but not directly by David's hand.

\subsubsection{Summary}

The book of Samuel, which records the founding of the Israelite monarchy, is quite significant for later intertribal relations, particularly between Benjamin and Judah as represented by Israel's first two kings. The book appears to incorporate early Saul traditions with later narratives of David's rise and reign. The narratives explain the abnormal transfers of leadership among the final judges and the initial monarchs. Levi, Ephraim and Benjamin are not fit to provide lasting political leadership to united Israel—only a Judahite can do so. David is not a perfect ruler, but he is the chosen of YHWH and relies upon him for strength and guidance. David is able to unify and defend Israel.

In Samuel, loyalty to YHWH's anointed king is rewarded. David exhibits loyalty to Saul because Saul is chosen by YHWH. When David becomes king, those Benjaminites (and others) who are loyal to him are exalted, but those who oppose him are destroyed-though not by David's hand. David is not directly responsible for the deaths of his enemies: Saul, Ishbosheth, Absalom, Shimei, Saul's grandsons.

The pro-David book of Samuel includes this message to Benjaminites: loyalty to the anointed Judahite leader is YHWH's will, and obedience will be rewarded. Such a message would have been particularly relevant in the late seventh or sixth centuries BCE, as suggested, with a Babylonian-era or early Persian-era date most appropriate.

\subsection{THE BOOK OF KINGS}

The Benjaminite content within the book of Kings differs greatly from that of the book of Samuel. Whereas David's story includes numerous interactions with Benjaminites, only a few relatively insignificant Benjaminite persons are mentioned by name in Kings. More significant to the present study are the references in Kings to historically Benjaminite locations-especially Bethel — and the three key instances of national/tribal realignment: the division of the kingdom under Rehoboam (1 Kgs 12), the capture of the Northern Kingdom (2 Kgs 17), and the fall of Judah to Babylon (2 Kgs 24-25).

\footnotetext{
${ }^{84}$ Knoppers, “Israel's First King,” 205.
} 


\subsubsection{Benjaminites}

The narrative of Solomon's accession to the throne contains three Benjaminite references relating to the book of Samuel, each consistent with the portrait of the relevant characters in Samuel.

In David's last instructions to Solomon, he exhorts his son to avenge the murders of Abner (2 Sam 3:27) and Amasa (2 Sam 20:10) committed by Joab (1 Kgs 2:5-6). David had previously promised that he would not harm Shimei the Benjaminite for cursing him as a usurper (2 Sam 16:5$14 ; 19: 16-23)$, but he craftily commands Solomon to do the job for him after his death (1 Kgs 2:89). David's final acts of faithfulness toward Abner and recompense toward Shimei reflect the Deuteronomist's generally positive attitude toward Benjaminites who acknowledged David's status as YHWH's anointed king, and hatred for David's opponents. Solomon fulfills David's requests for vengeance upon Joab and Shimei (1 Kgs 2:28-46). Solomon dismisses Abiathar the priest to his estate in Anathoth—a Levitical city within Benjamin (Josh 21:18)_for his role in the Adonijah affair (1 Kgs 2:26-27). ${ }^{85}$

Once Solomon consolidates his rule, he divides the kingdom into twelve administrative regions, each with its own official (1 Kgs 4:7-19). Shimei son of Ela is appointed over the region of Benjamin (4:18); not every tribe receives its own administrative region, but Benjamin does. Jebusites—presumably inhabitants of Benjaminite and Judahite areas—are among the non-Israelites

${ }^{85}$ Here the apparently irreconcilable differences between several Deuteronomistic traditions and $1 \mathrm{Chr} 6$ may be relevant to the present study. The question is whether the dismissal of Abiathar in favor of Zadok should be understood as Solomon choosing a Jerusalemite (Jebusite or Levite?) as priest in place of a Levite resident of Benjamin:

1) The Deuteronomist links Solomon's appointment of Zadok in place of Abiathar to the curse upon Eli's house (1 Sam 2:27-36) and the near extermination of the Elide priests under Saul from which only Abiathar, Eli's great-great-grandson, escaped (1 Sam 22:20-22; in Nob, also a Levitical city within Benjamin). Abiathar would then be understood as the fulfillment of 1 Sam 2:33 and 2:36.

2) In contrast to 1 Sam 22:20-22, 2 Sam 8:17 alleges that Zadok is an Elide (Levite) priest, a son of Ahitub.

3) Rendsburg suggests that the Zadok genealogy provided in 1 Chr 6 (MT 5:30-34 and 6:35-38) is an incredible attempt to graft a non-Israelite, Jebusite priest onto the line of Levi ("Internal Consistency," 196-198).

Zadok's pedigree in 2 Sam 8:17 is difficult to reconcile with 1 Sam 2:27-36 and 1 Kgs 2:26-35-particularly if the prophecy of 1 Sam 2:35 is understood as referring to Zadok (cf. McKenzie, "1 and 2 Samuel," 403). Contra Rendsburg, however, it is not necessary to place Zadok outside Israel or even the line of Levi. In contrast to 2 Sam 8:17 and in accord with $1 \mathrm{Chr}$ 6, Zadok could simply be understood as a Levitical priest from a line other than Eli's.

In summary, it is far from clear that Solomon's choice of Zadok over Abiathar should be understood as a preference for Judah Levites over Benjamin Levites. 
whom Solomon subjects to forced labor, but are not singled out among the Canaanites for the corvée (1 Kgs 9:20-22).

The relevance of the Deuteronomist's account of Gedaliah's provincial Mizpah government under the Babylonians (2 Kgs 25:22-26) will be addressed in more detail below. With regard to Gedaliah himself, his tribal status is unclear. ${ }^{86}$ Mizpah itself as a Benjaminite city is the more relevant datum from 2 Kings 25:22-26 for the examination of the Deuteronomist's portrait of Benjamin.

\subsubsection{Benjaminite Places}

Benjaminite places are much more prominent within the book of Kings than are individual Benjaminite persons. Given the administrative and cultic importance of Bethel, Gibeon and Mizpah in the Babylonian and early Persian periods, the portraits of those towns in Kings is particularly relevant.

\subsubsection{Jerusalem}

As has been shown (§5.2.3), Jerusalem’s history includes ambiguity of tribal status (Josh $15: 63 ; 18: 28$ ). From David's conquest onward (2 Sam 5:6-9), Jerusalem is the capital of the Davidide monarchs and is understood as primarily Judahite in Samuel and Kings. Nevertheless, the capital's proximity to the Benjamin border and its historic Benjamin connection should not be overlooked when considering the exilic or post-exilic reception of Kings.

For the Deuteronomistic authors-in all of the various sorts of redactional models that have been proposed ${ }^{87}$-Jerusalem is the only proper cultic center, since YHWH has "set his name to dwell there" (Deut 12:11). Even when the twelve tribes are divided into two nations, his understanding is that the Israelites should make pilgrimage to Jerusalem for the worship of $\mathrm{YHWH}^{88}$ - though non-Jerusalem Yahwistic worship and syncretism become the norm.

${ }^{86}$ Gedaliah is said to be grandson of Shaphan (25:22); Shaphan and his family are scribes who are often associated with the family of Hilkiah the priest (2 Kgs 22; Jer 29:3; 36:10-12; 39:14). Though the scribal and Levitical communities contained significant overlap, it cannot be said for certain whether Gedaliah is a Levite or a Benjaminite (or of another tribe, for that matter).

${ }^{87}$ See the discussion in Thomas C. Römer, The So-Called Deuteronomistic History: A Sociological, Historical and Literary Introduction (London: T\&T Clark, 2005), 27-43, 64-65.

${ }^{88}$ Knoppers writes of $1 \mathrm{Kgs}$ 12:26-33: "Like Rehoboam before him, Jeroboam attempts to subvert an arrangement in which Israel is to be politically, but not cultically, detached from Judah. Rehoboam sought political reunification, but Jeroboam's concerns are different. Jeroboam fears political reunification because of the cultic unity extant between Judah and Israel" (Two Nations Under God: The Deuteronomistic History of Solomon and the Dual Monarchies [2 vols.; HSM 52, 53; Atlanta: Scholars Press, 1993, 1994], II.24). 
The fall of Jerusalem is a major theme in the book of Kings. As dwelling place of YHWH and his anointed kings, Jerusalem is protected from invasion and conquest by Israel, Aram, Egypt and Assyria—despite the fall of Israel and Jerusalem's environs at various points. In the book's received form, it constitutes an explanation for theological catastrophe: the fall of Jerusalem, the captivity of the Davidide ruler, and the destruction of the temple.

Kings repeatedly compares and contrasts the Judahite kings with the Northern kings who worshiped at Bethel, "walking in the sins of Jeroboam son of Nebat." In the end, the consequences of Manasseh's sin could not be reversed by the purity reforms and cultic centralization instituted by Josiah. ${ }^{89}$ The Deuteronomistic tradition sought a new conception of YHWH's dwelling among his people, which could no longer be understood as the Jerusalem temple (1 Kgs 8:27-30; cf. Ezek $11: 16) .^{90}$

Given the crucial role of Jerusalem in Kings as the catalyst for a change in theological understanding, its geographic location on the border between Judah and Benjamin — particularly the temple site within Jebusite territory (2 Sam 24) — should not be underestimated. ${ }^{91}$ In a sense, any evolution in theological understanding that resulted from the changing fortunes of Jerusalem is experienced by Judah and Benjamin (and Levi) together. "Jerusalem" by synecdoche symbolizes Benjamin as well as Judah.

\subsubsection{Bethel}

Bethel's tribal status is similarly ambiguous within the DtrH. This Benjaminite town sits on the border between Benjamin and Ephraim, but is closely tied to Ephraim/Joseph (Jdg 1:22-26). Within Kings, Bethel is understood as a Northern city, reflecting the identification of Benjamin with the Northern Kingdom for at least part of the monarchic period (cf. §4.1.2).

Bethel is the most prominent "illicit" cultic site in Kings, and is most often mentioned in association with "unlawful” worship. Jeroboam, fearing that his people's pilgrimages to Jerusalem could result in political (and economic) reunification, establishes two golden calves in Dan and Bethel, the latter being his own primary high place (1 Kgs 12:26-33). Knoppers notes that this is a

${ }^{89}$ Jill Middlemas, The Templeless Age (Louisville: Westminster John Knox Press, 2007), 58.

${ }^{90}$ Middlemas, The Templeless Age, 58-59. See also the discussion of the contribution of the book of Lamentations to this notion of Zion's portability in Benjamin D. Giffone, "The Timeless, Unifying Rhetoric of Lamentations," OTE 25 (2012): 549-551.

${ }^{91}$ Jonker, "Of Jebus, Jerusalem and Benjamin," 83-84. There is a long tradition of placing a capital city on the border between opposing factions/regions: Washington, D.C., on the border of the early American north and south (1790); Ottawa between Ontario and Quebec and equidistant to Toronto and Quebec City (1857); Canberra equidistant to Melbourne and Sydney (1927). See also the comparisons drawn between Jerusalem and Washington, D.C., in Yigal Levin, "Joseph, Judah and the 'Benjamin Conundrum,"” ZAW 116 (2004): 228-229. 
religiously conservative move for Jeroboam, given the religious history of these sites. ${ }^{92}$ While the Dan high place is never "sanctioned" in the DtrH (Jdg 18:30-31), Bethel has an ancient aetiology (Gen 28) and a long tradition of "orthodox" worship (Jdg 20:18, 26; 21:2; 1 Sam 7:16; 10:3).

Bethel's deficiency is merely that it is not Jerusalem, which is now-within the narrative- the only proper high place. Jeroboam's use of a golden calf (linked to the worship of Baal) and a religious calendar of his own device (rather than that established in the Law) heighten the contrast with Jerusalem.

Negative references to Bethel abound in Kings. Bethel is the site of a miracle by man of God prophesying against its altar (13:1-10); the man of God is subsequently led astray by a Bethelite prophet and mauled by a lion (13:11-32). After the deportation of the Northern Kingdom, a Samarian priest returns to Bethel to teach the resettled, lion-plagued "non-Israelite" peoples how to worship YHWH-though not to the author's satisfaction (2 Kgs 17:24-34, 41). During Josiah's reforms, vessels in the Jerusalem temple that had been made for Baal and Asherah are burned outside Jerusalem and the ashes taken to Bethel (2 Kgs 23:4). Josiah breaks down the high place at Bethel and defiles the altar by burning the bones of its priests on it, though he leaves undisturbed the tomb of the man of God who predicted these things (2 Kgs 23:15-18).

The Bethel cult under Jeroboam and his successors results in disregard for YHWH's true prophets. 1 Kings 16:34 recounts that Hiel of Bethel rebuilt Jericho at the cost of two sons, as predicted by Joshua (Josh 6:26). This lone verse "[reminds] us that Bethel has now become a thoroughly impious city, whose residents treat Joshua's 'prophecy' with contempt." 93 Bethelite youths mock Elisha's pate and are mauled by bears (2 Kgs 2:23-24). Despite these significant blemishes, Bethel is home to some (at least marginally) pious prophets of YHWH (1 Kgs 13:11; 2 Kgs 2:3).

\subsubsection{Gibeon, Mizpah, and Other Benjaminite Locations}

The Deuteronomist seems somewhat embarrassed about Solomon's private worship at the Gibeon high place (1 Kgs 3:2-4) — an embarrassment not shared by the Chronicler, who assumes that the tabernacle made by Moses was the proper venue for a (national, not private) religious occasion (2 Chr 1:3)! Nevertheless, the DtrH records YHWH's appearance to Solomon in a dream at Gibeon (1 Kgs 3:5-14), after which Solomon journeys to Jerusalem to offer sacrifices before the Ark (3:15).

92 Knoppers, Two Nations Under God, II.35-36.

${ }^{93}$ Iain W. Provan, "1 and 2 Kings," in The New Oxford Annotated Bible (NOAB), Michael D. Coogan, ed. (New York: Oxford University Press, 2007), 521. 
Minor mentions of Benjaminite locations in Kings include little in the way of positive or negative portrayal. Asa of Judah pays Ben-hadad of Aram to attack northern Israel in order to deflect Baasha's efforts to fortify Ramah; Asa steals the building materials from the Ramah project and uses them to fortify "Geba of Benjamin and Mizpah" (1 Kgs 15:16-22). The narrative of Elijah's assumption moves from Gilgal to Bethel to Jericho, and then to the Jordan where Elijah is taken into heaven (2 Kgs 2:1-12). Elisha then performs a miracle in Jericho (2:19-22), and at Bethel confronts the mocking youths (2:23-24). Josiah's reforms include the destruction of high places "from Geba to Beer-sheba," possibly mapping the northern and southern extent of Judah at that time (2 Kgs 23:8). ${ }^{94}$ Zedekiah is captured by the Babylonians at Jericho (2 Kgs 25:5).

Mizpah becomes the administrative seat of Gedaliah's provincial government under the Babylonians (2 Kgs 25:22-26; Jer 40-41). The historical circumstances surrounding the arrangement have been discussed at length in the previous chapter (\$4.1.2-4.1.3). Several relevant points may be made concerning this reference to Mizpah. The account of this (perhaps) five-yearlong administration ${ }^{95}$ is remarkably brief. Jeremiah's support for the Mizpah administration is not mentioned (Jer 40-41), nor is any Mizpah cult (as is suggested in Jer 41:5). ${ }^{96}$ This Benjamin-based government is quite unsuccessful, but the attempted Davidide coup brings greater calamity upon Judah. Given that the events described were probably within living memory for some in the Deuteronomist's audience, the brief Mizpah account should be taken merely as a presentation of historical fact, not as a polemical statement about Judah and Benjamin-in contrast, for example, to the strong anti-Bethel rhetoric that would have been relevant in a exilic or post-exilic context.

\subsubsection{Benjamin Between Two Kingdoms}

In addition to a few references to Benjaminite persons and places, the book of Kings refers to Benjamin directly and indirectly in accounts of the division of the kingdom and the interactions of Israel and Judah. Portions of the previous chapter focused on Benjamin's history "behind" the Deuteronomistic narratives of this period; this section considers briefly the relevance of the theological content of Kings concerning Israel, Benjamin, and Judah.

94 Though Josiah's reform efforts extend into Samaria and include the slaughter and desecration of living priests, not just the bones of dead priests as at Bethel (2 Kgs 23:19-20).

${ }^{95}$ That is, if the third deportation described in Jer 52:28-30 (582 BCE) is Nebuchadrezzar's response to Gedaliah's assassination.

${ }^{96}$ Klaus-Dietrich Schunck, "Benjamin,” Anchor Bible Dictionary, vol. 1. (trans. Phillip R. Callaway; ed. David Noel Freedman; New York: Doubleday Publishing, 1992), 672-673; Philip R. Davies, “The Origin of Biblical Israel,” in Essays on Ancient Israel in Its Near Eastern Context: A Tribute to Nadav Na'aman (ed. Yairah Amit et al.; Winona Lake, IN: Eisenbrauns, 2006), 142-144. 
Kings idealizes the united, peaceful, prosperous kingdom of Israel under Solomon (1 Kgs 4:20-28). Solomon's disobedience irreparably ruptures that unity (11:11-13). Jeroboam, an Ephraimite (11:26), is YHWH's instrument by which “ten" tribes are torn from David's kingdom and only "one" is left (11:30-36). Israel is thus returned to a sub-optimal situation of Ephraimite rule, reminiscent of the pre-Davidic days of Joshua, the Josephite judges, or Samuel the prophet. The result is further cultic unfaithfulness and religious degeneration (12:26-13:10).

Benjamin, the "twelfth" tribe, sits precariously—geographically and rhetorically—between the two kingdoms. 1 Kings 12 obliquely communicates the division of Benjamin. Benjaminites are no doubt included in "the sons of Israel who lived in the cities of Judah" who remained subject to Rehoboam (12:17). Verse 20b states, "None followed the house of David except the tribe of Judah alone (לבדו)."97 Yet Rehoboam is able to muster "all the house of Judah and the tribe of Benjamin" (12:21) and "all the house of Judah and Benjamin" (12:23). Meanwhile, Bethel becomes the site of Northern idolatry (12:29).

Despite the division of the tribes into separate political entities in accordance with YHWH's plan, Kings idealizes the religious unity of the twelve tribes. The Bethel altar is condemned (1 Kgs 13:2-3). Elijah's altar at Carmel has twelve stones, emphasizing for the Northern Kingdom its religious identity with Judah as part of a larger covenant body (1 Kgs 18:31; cf. Josh 4). The "silver lining" of the Assyrian deportation (2 Kgs 17) is that the absence of a Samarian government allows Josiah's religious reforms to extend northward into Benjaminite and Josephite territory (Bethel and Samaria) in a futile attempt to restore cultic unity (2 Kgs 23:15-20).

The divided status of Benjamin in Kings epitomizes the Deuteronomist's attitude toward the division of the kingdom. Political division was a lamentable but understandable attempt to spark repentance and reform in the twelve tribes (1 Kgs 12:24; 14:7-9). But neither kingdom is able to follow YHWH as David did, and exile is the consequence. In relation to Judah, the sinful Davidide kings are Benjamin's problem, whereas in relation to the Northern Kingdom, Bethel-Benjamin itself-represents the problem.

\subsubsection{Summary}

The book of Samuel seeks to justify David as YHWH's choice over-against the house of Saul. The book of Kings seeks to justify the division and eventual destruction of David's kingdom. In Kings, individual Benjaminite persons are insignificant-more important are the actions of Judahite and Northern kings in relation to Benjamin as a tribe and as a region.

\footnotetext{
${ }^{97}$ Interestingly, this statement is absent from $2 \mathrm{Chr} 10$, which states quite clearly that Benjamin followed
} Rehoboam. 
Any assessment of Benjamin's fate as presented in Kings will parallel one's opinion of the tension between the competing theological emphases in the book: the Davidic promise, and the covenant curses of Deuteronomy (Deut 27-29). An approach that considers the Davidic promise within the DtrH (or one of the DtrH's redactional layers) as "trumping" the Deuteronomic curses ${ }^{98}$ might emphasize Benjamin's relative success in connection to Judah over-against Israel. An approach that favors the Deuteronomic curses as the DtrH's overriding principle ${ }^{99}$ might consider the exile to have been an inevitability—and Benjamin's association with North or South an irrelevancy.

Like Samuel, Kings contains quite a bit of material that could have elicited a negative response from Benjaminites in the Babylonian and early Persian periods. The Deuteronomistic perspective, despite its negative portrayals of sinful Southern kings, is unapologetically pro-David and Judah-centered. Benjaminites could argue quite understandably from the DtrH that David had usurped Saul's kingdom, and that David's descendants had mismanaged Israel, leading to the exile.

The most prominent Benjaminite references within Kings are condemnations of the Bethel cult, which likely continued into the Babylonian and Persian periods. Kings' strong anti-Bethel sentiment, as will be shown, is replaced in Chronicles by an even stronger pro-Jerusalem message.

\subsection{SUMMARY AND ANALYSIS}

This chapter focuses on the literary and theological representation of Benjamin in the DtrH, rather than the historical events these books purport to recount. The assumption is that the DtrH and Chronicles provide indirect "snapshots" of intertribal relations at two points in Judah's history. The DtrH is the first of these representations, and provides much of the material from which the Chronicler crafts his later snapshot of Benjamin.

The books of the Former Prophets, which are considered to constitute the so-called Deuteronomistic History, incorporate a wide variety of literary and theological traditions, including traditions that are Northern, Benjaminite, and Judahite in origin. Though the collection tells a grand narrative of Israel from Moses to the exile, each book has its own unique emphases and combination of traditions-with a variety of implications for a Benjaminite audience.

The book of Joshua includes a mixture of traditions, balancing its portrayal of Judah, Benjamin and Joseph. Much of the narrative is set in Benjaminite territory, and the boundaries of

\footnotetext{
${ }^{98}$ Stemming from, for example, von Rad or Wolff; see Middlemas, The Templeless Age, 60-61.

${ }^{99}$ Following, for example, Noth or Cross; see Middlemas, The Templeless Age, 59; Römer, The So-Called
} Deuteronomistic History, 21-29; Gary N. Knoppers, "Is There a Future for the Deuteronomistic History?" in The Future of the Deuteronomistic History (Thomas C. Römer, ed.; BETL 147; Leuven: Leuven University Press, 2004), 119-134. 
Benjamin relative to Judah, Ephraim and Manasseh are carefully delineated, with significant implications for later intertribal relations.

The book of Judges contains a core of Northern traditions, which are co-opted by the editor in service of a pro-Judah, pro-David agenda by the addition of several chapters at the beginning and end of the book. The Northern and Benjaminite judges are presented as inadequate, highlighting Israel's need for Judahite leadership.

The book of Samuel builds a pro-David narrative on top of earlier Saul traditions, emphasizing Saul's inadequacy as king and David's election by YHWH. Morally, David is far from perfect, but his actions are justified in the narrator's view by his position as YHWH's anointed. The interactions between David and Saul's house are presented in a polarizing manner: it seems unlikely that a partisan of either royal house would be persuaded to empathize with the opposing house. The establishment of Jerusalem as the capital of Judahite kings and as the future temple site within Benjaminite terrirory has significant implications for its suitability as an administrative and cultic center for future generations.

The book of Kings also divides its attention between Northern and Southern events. Benjamin's political status appears ambiguous, and the region is divided. No individual Benjaminites are prominent, though Bethel is a major blemish on the Northern Kingdom. In Kings, the failures of the Davidide monarchs result in the division and weakening of the entire kingdomBenjamin in particular. Severed politically from "south Benjamin" and Judah, Bethel becomes a continual snare that leads to the deportation of the Northern tribes. The fall of Jerusalem, YHWH's chosen home according to the Deuteronomist, becomes a catalyst for theological change that is relevant to "all Israel."

The Deuteronomistic editors, in the pursuit of various theological and ideological goalsthe legitimation of the Davidic monarchy, a Deuteronomic explanation for the division of the kingdom and the exile, etc.- -included quite a bit of divisive material within this account of Israel's rise and fall. The DtrH presents the struggles of Israel's tribes in all their messiness-including facts or interpretations that a Benjaminite audience would dispute, or facts that could easily be incorporated into anti-Judah rhetoric.

The next chapter will consider whether a re-presented history of Israel could have been designed in part to smooth those tensions. The Chronicler, from a later historical vantage point with different sociopolitical and religious concerns, pursued different theological and ideological goals, using diverse materials and methods. How does Benjamin fare in the Chronicler's presentation of Deuteronomistic material and in the Sondergut? How might Benjaminite communities have received Chronicles, and what role might the historical memory represented by Samuel-Kings have played in that reception? 


\section{Chapter 6: Benjamin in Chronicles}

\subsection{CRITERIA AND METHOD}

The present chapter focuses on the literary portrayals of Benjamin and intertribal relations in the book of Chronicles. The scope and method of the study have much in common with those of the previous chapter, but with some necessary points of divergence.

\subsubsection{Focus}

The criteria for consideration within a study of Benjamin in Chronicles differ slightly from the criteria for a study of Benjamin within the DtrH. There are significantly fewer Benjaminite individuals referenced in Chronicles than in the DtrH. With respect to geography, which locations are considered part of Benjamin for the Chronicler? Are the borders of Benjamin to be understood as they might have been in the Chronicler's day, or in some other historical moment—and how might this be determined?

The question of geography is not quite as difficult as it initially appears. As will be shown, very few of the DtrH's references to Benjaminite places (other than Jerusalem) are adopted by the Chronicler ${ }^{1}$ - yet most of the key Benjaminite locations in the DtrH are referenced in Chronicles. Thus, it does not appear that the Chronicler attempts to redraw the borders of Benjamin to any significant degree.

Whereas source-critical study of Benjaminite (and Northern) material within the DtrH is strictly theoretical, direct comparison of Chronicles to its sources is essential. Benjaminite material considered in relation to Chronicles may be divided into three categories, with one of those categories further subdivided:

1) Benjaminite material within sections of Chronicles that have no parallel in the DtrH;

2) Benjaminite material within sections of Chronicles that have been adopted from the DtrH;

2a) Benjaminite material adapted directly from the DtrH;

2b) Benjaminite supplements to the Deuteronomistic narrative; ${ }^{2}$

${ }^{1}$ Louis C. Jonker, “Of Jebus, Jerusalem and Benjamin: The Chronicler’s Sondergut in 1 Chronicles 21 Against the Background of the Late Persian Era in Yehud," in Chronicling the Chronicler: The Book of Chronicles and Early Second Temple Historiography (ed. Tyler F. Williams and Paul S. Evans; Winona Lake, IN: Eisenbrauns, 2013 ), 86-88.

${ }^{2}$ This category would be distinguished from the first in that the "Category 1" narratives have no direct parallel in DtrH. For example: 1 Chr 26:28 (Saul's and Abner's war spoils) would be "Category 1" because it falls within 1 Chr 
2c) Benjaminite material omitted from the DtrH narrative;

3) Significant sections omitted from the DtrH that contain Benjaminite material. ${ }^{3}$

\subsubsection{Approach}

Benjaminite content within Chronicles may be evaluated according to two general criteria:

1) What is the Benjaminite element of this literary unit?

2) Does the Benjaminite element relate to the author's intended message in this literary unit, and if so, how? ${ }^{4}$

A previous chapter (\$3.3.3) suggested some ways that the Benjaminite content (and perhaps a Benjamin-related message) within Chronicles might support and integrate with recognized themes of the book as a whole. This chapter tests this theory on a case-by-case basis, keeping in mind the varying and complex purposes of the Chronicler and the general polyvalence of texts.

Given the Chronicler's reliance upon Samuel-Kings as a source (cf. §3.2), the following criteria will guide the analysis of the Benjaminite elements of the Chronicler's material that parallels the DtrH:

3) How text-critically certain is it that this divergence from the DtrH reflects the editorial hand of the Chronicler?

4) Does the Chronicler change the Benjaminite element of the DtrH literary unit, and if so, how?

a. If the Benjaminite element is retained unchanged, is its meaning within the Chronicler's literary unit significantly different from its meaning within the DtrH?

b. If the Benjaminite element is changed, how is it different, and does its meaning within Chronicles diverge from the meaning within the DtrH?

5) What is the meaning of Benjaminite additions by the Chronicler to the Vorlage?

22-29, which has no direct parallel in DtrH, whereas $1 \mathrm{Chr}$ 21:6 (Levi and Benjamin excluded from the census) would be a "Category $2 b$ " addition to the narrative adapted from 2 Sam 24.

${ }^{3}$ This category would be distinguished from $2 \mathrm{c}$ in that the "Category 3 " material has no direct parallel in Chronicles. For example: 2 Sam 6:20-23 (Michal chides David) would be "Category 2c" because the Chronicler adapts the larger story of the ark's arrival in Jerusalem (1 Chr 15-16; 2 Sam 6:12-19) but excludes those verses, whereas 2 Sam 20 (Sheba's uprising) would be a "Category 3" Benjaminite exclusion without any narrative parallel in Chronicles.

${ }^{4}$ The historical question of how a Benjaminite audience might have interpreted such a literary unit will be deferred to the next chapter. 
6) Why did the Chronicler exclude this Benjaminite element found within the DtrH? Is the exclusion primarily or secondarily due to the Benjaminite content, or is the exclusion merely a necessary consequence of another editorial/authorial purpose?

\subsubsection{Outline}

The examination of Benjamin and Chronicles is divided into three sections. The first section will proceed topically by examining the portrait of Benjamin, Benjaminites, and Benjaminite places in Chronicles. The second section will consider Benjamin in Chronicles synoptically, section by section. A third section will consider key Benjaminite topics and sections with Benjaminite content in the DtrH that are omitted by the Chronicler.

\subsection{BENJAMIN, BENJAMINITES, AND BENJAMINITE PLACES}

In an essay considering a the possibility of "a Benjaminite interest" in 1 Chronicles 21 , Jonker briefly surveys references to Benjamin in Chronicles, focusing on the genealogical introduction of 1 Chronicles 1-9, occurrences of "Benjamin" or "Benjaminite," and the use of key terms such as the personal name "Saul" and certain place names. ${ }^{5}$ This study attempts to build on Jonker's focused inquiry by broadening in scope to include all potential Benjaminite material in Chronicles. The goal is to discover whether such a "Benjaminite interest" is present throughout the book, and what sort of rhetorical goals and strategies may be attributed to the Chronicler.

\subsection{1 "Benjamin" and "Benjaminite"}

Chronicles contains thirty references to "Benjamin" or "Benjaminite(s)" (see Appendix: Table 1). Of these thirty occurrences, nine are located in the genealogies (1 Chr 1-9). The remaining occurrences are clustered somewhat unevenly throughout the other sections of Chronicles. Only three of these twenty-one references in the narrative section of Chronicles are from the Vorlage, while the overwhelming majority are unique to Chronicles.

\begin{tabular}{|c|c|c|c|}
\hline "Benjamin"/"Benjaminite(s)" & 1 Chr 1-9 & $\begin{array}{c}1 \mathrm{Chr} 10-29 ; \\
2 \mathrm{Chr}\end{array}$ & $\begin{array}{c}1 \text { Sam } 31 ; 2 \text { Sam; } \\
1-2 \mathrm{Kgs}\end{array}$ \\
\hline Total References & \multicolumn{2}{|c|}{30} & 19 \\
\hline Unique References & 9 & 18 & 16 \\
\hline Common References & N/A & \multicolumn{2}{|r|}{3} \\
\hline Total Chapters & 9 & 56 & 72 \\
\hline
\end{tabular}

\footnotetext{
${ }^{5}$ Jonker, “Of Jebus, Jerusalem and Benjamin," 85-87.
} 
Jonker makes several pertinent observations concerning these references in Chronicles. First, "Benjamin" and "Benjaminite" occur in all parts of Chronicles: the genealogies, the histories of David and Solomon (1 Chr 10-29 and 2 Chr 1-9), and the history of Judah's kings (2 Chr 1036). ${ }^{6}$ Second, “The term 'Benjamin' occurs almost exclusively (with the exception of five occurrences in Rehoboam's narrative) in the narratives about those kings who were evaluated positively by the Chronicler (namely David, Asa, Jehoshaphat, Amaziah, Hezekiah, and Josiah)."7 Third, ten occurrences of "Benjamin" are as part of the phrase, "Judah and Benjamin." 8

An additional observation should be made regarding the distribution and frequency of these references. The narrative section of Chronicles parallels 1 Samuel 31, 2 Samuel, and 1-2 Kings: seventy-two chapters in all. These seventy-two chapters include only nineteen references to "Benjamin" or "Benjaminite(s)," whereas the corresponding narratives in Chronicles_constituting only fifty-six chapters-include more references within a smaller corpus. At the very least, this indicates that although the Chronicler has narrowed the focus by trimming from the narrative, overall direct attention to Benjamin collectively has not diminished. What exactly has been removed in the sixteen DtrH references to "Benjamin" or "Benjaminite(s)" omitted by the Chronicler? This question will be considered in greater detail (\$6.4).

\subsubsection{Benjaminite Persons}

With the exception of 1 Chronicles 10, no narrative in Chronicles includes a Benjaminite as a primary character. References to Benjaminite persons in Chronicles are concentrated in the genealogies and the account of David's supporters (1 Chr 7:6-12; 8:1-40; 9:7-9, 35-44; 12:1-7), and dispersed as minor characters within narratives concerning Davidide kings.

The paucity of references to Benjaminite figures in Chronicles in comparison with SamuelKings does not by itself indicate that the Chronicler thinks less of Benjamin than the Deuteronomist. Many important non-Benjaminite figures-Eli, Samuel, Jeroboam, Elijah, Elisha, etc.- - receive diminished attention or none at all in Chronicles. The Chronicler's narrowed focus on the Davidide kings and their administrative and religious contributions displaces or submerges certain themes and figures of the DtrH-Benjaminite and non-Benjaminite. The relevance of this narrowed focus to a shift in stance toward Benjamin will be considered below.

The concern of the present section is the portrait of Benjaminites in Chronicles. The narrative sections of Chronicles contain a handful of references to Saul and his family. Certain figures in the narrative sections of Chronicles are known to be Benjaminite from a narrative

\footnotetext{
${ }^{6}$ Jonker, "Of Jebus, Jerusalem and Benjamin," 86.

${ }^{7}$ Jonker, "Of Jebus, Jerusalem and Benjamin," 86.

${ }^{8}$ Jonker, “Of Jebus, Jerusalem and Benjamin," 86-87.
} 
context. Others might be understood as Benjaminite when a narrative is read in conjunction with the genealogies.

\subsubsection{Saul and His Family ${ }^{9}$}

A comparison of the portraits of Saul—perhaps the most important Benjaminite in the Hebrew Bible-within the DtrH and Chronicles deserves extended treatment in a later section. This sub-section focuses narrowly on the portrayal of Saul and his family members in 1 Chronicles (see Appendix: Table 2), and their contribution to an overall presentation of Benjaminites in Chronicles.

Saul and his sons are part of the genealogy of Jeiel (1 Chr 8:29-40). This genealogy that extends to the post-exile is mostly repeated in 1 Chronicles 9:35-44 to provide a connection between the era of the returnees and the narrative of Saul's death (1 Chr 10).

In describing Saul's death, the Chronicler unambiguously denigrates his reign (10:14), his military might (10:1), his courage (10:4), and his moral character (10:13-14). At Hebron, all Israel affirms that David was the true leader of Israel even while Saul was still king (11:2). ${ }^{10}$ Numerous Benjaminites from Saul's own clan had begun to defect to David while Saul was still alive (12:118). Before the assembly, David expresses regret that the people had not "sought the Ark in the days of Saul" (13:3). ${ }^{11}$ In an oblique reference, YHWH promises not to remove his hesed from David's son, "as I removed it from him who was before you" (17:13).

Yet Chronicles includes two references to Saul that could be understood positively. The first mention of Saul in Chronicles is the passing mention of the Reubenites' conquest of the Hagrites, which is said to have occurred "in the days of Saul" (1 Chr 5:10). Knoppers and Klein hesitate to allow this to reflect positively on Saul, since no evidence is given of Saul's direct involvement. ${ }^{12}$

${ }^{9}$ The following section incorporates material from my unpublished paper, "Sleeping Dogs: Benjamin-Judah Relations in the Persian Period and the Chronicler's Portrait of Saul," presented at the Mid-Atlantic Regional meeting of the Society of Biblical Literature in Baltimore, MD, in March 2013. I am grateful to the conference participants for their constructive feedback.

${ }^{10}$ Gary N. Knoppers, "Israel's First King and 'the Kingdom of YHWH in the hands of the sons of David': The Place of the Saulide Monarchy in the Chronicler's Historiography," in Saul in Story and Tradition (ed. Carl S. Ehrlich and Marsha C. White; FAT 47; Tübingen: Mohr-Siebeck, 2006), 187.

${ }^{11}$ Yairah Amit, "The Saul Polemic in the Persian Period," in Judah and the Judeans in the Persian Period (ed. Oded Lipschits and Manfred Oeming; Winona Lake, IN: Eisenbrauns, 2006), 651-52.

${ }^{12}$ Knoppers observes that Reuben's campaign is independent of the rest of Israel; however, he admits that all these independent campaigns mentioned in the genealogies is successful, in contrast to the independent campaigns of Jdg 1 (1 Chronicles 1-9 [Anchor Bible Commentary; New York: Doubleday, 2004], 398). Ralph W. Klein writes of 5:10: "Such a war is not attested in other biblical passages, nor is it clear how the Reubenites related to the authority of King Saul himself in this battle" (1 Chronicles: A Commentary [Hermeneia series; Minneapolis: Fortress Press, 2006], 163-164). 
Yet in 1 Chronicles 20, Joab's victories over Ammon are considered a feather in David's cap. The Reubenite campaign could be viewed as a positive reflection on Saul's reign. Arguably the only overtly positive reference to Saul in Chronicles is a passing mention of his war spoils contributing to the treasury for the building of the House of YHWH (1 Chr 26:27-28).

1 Chronicles 8:33//9:39 lists four sons of Saul: Jonathan, Malchi-shua, Abinadab, and Eshbaal. Eshbaal is never mentioned in the narrative section of Chronicles, and the first three brothers are killed at the very beginning of the narrative (1 Chr 10:2, 6). Interestingly, the three slain sons and Saul together—without Eshbaal—are said to constitute "his whole house" ( כל־ביתו יחדו מתו), an addition to the Vorlage (1 Sam 31:6).

The Chronicler's lone reference to Michal, daughter of Saul and wife of David, is a single verse in the narrative of the ark's successful journey to Jerusalem (1 Chr 15). Michal looks out the window as the ark approaches the tent which David has set up for it, and she despises David for "leaping and dancing" (1 Chr 15:29).

In addition to these references to the direct descendants of Saul, Chronicles includes two (Sondergut) references to Saul's uncle and cousin, Abner and Jaasiel. Abner is the son of Ner (1 Chr 26:28), Saul's grandfather (8:33//9:39). Abner's war spoils are used to fund the construction of the temple, along with the spoils of Samuel, Saul and Joab (26:28). Jaasiel, son of Abner and cousin of Saul, is listed as the tribal head of Benjamin in David's administration (27:21).

One is struck by the Chronicler's relative silence concerning the members of Saul's house. Aside from 1 Chronicles 10, only the references to Michal and Jaasiel describe events that actually occur within the Chronicler's story-the references to Saul and Abner describe events anterior to the Chronicler's narrative of David. After Saul's death, he and his household are relegated nearly completely to a previous era, an insecure, unstable, irreligious time in Israel's history. Yet Saul's line continues all the way to the postexilic period (9:35-44), his daughter is queen (15:29), and his cousin is head of the tribe of Benjamin (27:21).

\subsubsection{Benjaminites Known from the Narratives}

In addition to the members of Saul's household, several Benjaminite figures appear in Chronicles (see Appendix: Table 3). All of these figures are referenced in military contexts.

The list of David's mighty men in 1 Chronicles 11:10-47 mentions two Benjaminites by name: Abiezer of Anathoth (11:28b), and Ittai son of Ribai "from Gibeah of the sons of Benjamin" (11:31a). Abiezer is later listed as the commander of David's ninth military division (27:12). These two are honored as David's trusted commanders, though "not attaining to the Three." 
1 Chronicles 12 lists Benjaminites who defected to David at Ziklag while Saul was still alive (12:2-7, 16-18 [MT 12:2-8, 17-19]), and mentions others who gathered to David at Hebron during the (implied) war of succession with Ishbosheth (12:29 [MT 12:30]).

Abijah's mother is described in 2 Chronicles 13:2 as "Micaiah daughter of Uriel of Gibeah," which differs from 1 Kings 15:2 ("Maacah daughter of Abishalom").

2 Chronicles 14:8 (MT 14:7) records that Asa's army included 300,000 from Judah and 280,000 from Benjamin, and that the Benjaminites in particular "wielded the bow" (דרכי קשת).

In 2 Chronicles 17:17-18, Eliada and (perhaps) Jehozabad of Benjamin are the fourth and fifth of Jehoshaphat's five military commanders. With Eliada were 200,000 warriors "armed with bow and shield" (נשקי־קשת ומגן)—Eliada's Benjaminites are the only warriors described specifically as archers.

The references to non-Saulide Benjaminites in 1 Chronicles 12 and 2 Chronicles are remarkable in two respects. First, they are part of the Chronicler's Sondergut. Second, these references (with the exception of 2 Chr 13:2b) reinforce the Primary Narrative's traditional characterization of Benjaminites as archers and slingshot experts, as well as the fascination with Benjaminite ambidexterity or left-handedness. ${ }^{13}$ Benjaminite skill with the bow in 2 Chronicles strategically complements Judahites' skill with shield and spear. Left-handedness and ambidexterity, as discussed previously $(\S 5.3 .3, \S 5.3 .6)$, is associated with deviance and craftiness, particularly when paired with the traditional designation as "Benjaminite," "right-hand son." In contrast to Judges 3:21 and 20:16, the "left-handed/ambidextrous Benjaminite" motif becomes a positive feature of the tribal characterization in Chronicles, since these "traditional" skills are used in the service of David ${ }^{14}$ or a Davidide king to complement Judahite warriors-rather than to oppose Judah, as in Judges.

\subsubsection{Benjaminites Known from the Genealogies?}

In addition to the characters described in the narrative as Benjaminite or Saulide, the next question is whether any characters within the narratives might have been understood by the Chronicler as Benjaminite through connection to the genealogies. It is clear enough that the genealogies are intended to establish relationships between peoples, tribes, clans and families, and

\footnotetext{
${ }^{13}$ Interestingly, no mention is made in Chronicles of David's renowned skill with the sling (1 Sam 17:50), though the Chronicler harmonizes in David's favor the contradictory accounts of Goliath's death (1 Sam 17:50; 2 Sam 21:19; 1 Chr 20:5).

${ }^{14}$ Compare also the account of Jonathan's skill with the bow, which he uses to communicate with David to save David’s life (1 Sam 20:20-22, 35-40). As discussed previously (§5.4.3.1), Jonathan is something of an ideal Benjaminite for the Deuteronomist.
} 
that the Chronicler appears to "graft" key figures into certain tribes/families for various reasons (e.g., Caleb and Samuel; cf. §5.2.3, §5.4.2.2). Do the genealogies point to any characters in the narrative of Chronicles that might have been understood as Benjaminites by the author, or whom the author intends to "graft into" the tribe of Benjamin?

1 Chronicles 13:7 is an interesting possibility in this regard. As the ark is brought from Kiriath-jearim, it departs "from the house of Abinadab," and is driven on a cart by "Uzza and Ahio" (מבית אבינדב ועזא ואחיו נהגים בעגלה). Could the association of these three names, in conjunction with the genealogies, indicate that any or all of these men are to be understood as Benjaminite? The evidence is suggestive but not conclusive.

First, each of the names appears twice in the genealogies (1 Chr 1:1-9:1), but the names are linked only by the Benjaminite list. "'Abinadab" is the name of David's brother (2:13) and Saul's son (8:33). "Uzza('/h)” is the name of a Levite (עזה; 6:29 [MT 6:14]) and a Benjaminite (עזה 6: "'Ahio" is the name of two Benjaminites $(8: 14,31)$. Second, other than 1 Chronicles 10:2 (Saul's sons' death), none of the names occurs in Chronicles outside 1 Chronicles 13 and the genealogies.

Third, in the Chronicler's presentation Uzza's and Ahio's status as non-Levites is one of the reasons for the failure to bring up the ark. Knoppers notes that although "Uzza(h)" is referenced in the Levitical genealogy, "the Chronicler's later comment upon the failure of the first attempt to bring the Ark into the City of David suggests that he did not regard either Uzza or Ahio as of Levitical descent (15:13)."15 Klein observes a relevant omission by the Chronicler: "The two men who drove the cart are introduced in Chronicles without mentioning the other details about them contained in 2 Samuel 6. According to Samuel, but not in Chronicles, the two men were sons of Abinadab, at whose house the ark had stayed."16

In summary, we have two men who are not of Levitical descent, whose names are linked in Chronicles only by this incident and inclusion in the Benjaminite genealogy. It is possible, though not certain, that the Chronicler understood these men as Benjaminites.

There are several difficulties with this suggestion. The first concerns the identity of Abinadab, who has hosted the ark in his house at Kiriath-jearim, "which belongs to Judah" (13:6). This does not appear to be Saul's son, but it could possibly be David's brother (2:13) or another Judahite. If this Abinadab is not Benjaminite, then a Benjaminite connection between the other two figures appears less likely.

${ }^{15}$ Knoppers, 1 Chronicles 10-29 (Anchor Bible Commentary; New York: Doubleday, 2004), 587. Klein contends, "There seems to be no reason to connect the Uzzah in this genealogy [1 Chr 6:14] with the Uzzah who died for touching the ark" (1 Chronicles, 333n33).

${ }^{16}$ Klein, 1 Chronicles, 333. 
Second, the word אָּזיו that is understood as a proper name in the MT could also be vocalized

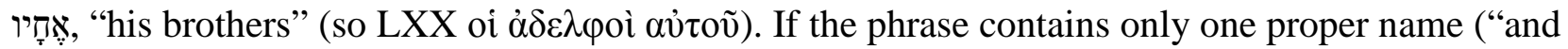
Uzza and his brothers drove the cart"), then the connection to the Benjaminite genealogies becomes even weaker.

This example highlights the difficulties in using the genealogical material to identify the tribal associations of various characters in the narrative. We have not even considered the implications of relegating the genealogical introduction and the narrative to separate redactions of the book. Perhaps it is not possible to make connections strong enough to definitively identify tribal identities that are indefinite in the narrative. But perhaps the Chronicler (or the final editor of Chronicles) intended to allow the reader some flexibility in associating names in the genealogies with characters in the narrative, a form of midrash used by later Jewish interpreters.

In addition to "Benjamin" and "Saul," 138 personal names are mentioned in 1 Chronicles 7:6-12 $2^{17}$ and 8:1-40. ${ }^{18} 207$ instances of those 138 names may be found in 151 verses within the narrative of Chronicles (1 Chr 10-2 Chr 36). Yet a great many of these occurrences refer to characters that are unambiguously non-Benjaminite within the narrative context. For example, these "Benjaminite" names from the genealogies occur a total of fifty-four times in 1 Chronicles 15-16 and 23-26; however, fifty-two of the persons called by those names are Levites!

Only in a few instances might the Benjaminite lists of names be used to suggest Benjaminite identity for minor figures in the Chronicles narratives:

${ }^{17}$ This "preliminary" genealogy is attributed to Benjamin, grouped with Northern tribes of Issachar (7:1-5), Naphtali, Manasseh, Ephraim, Asher (7:13-40), contains parallels to more extensive genealogy of Benjamin in 1 Chr 8. It has been suggested that 7:6-12 was originally a Zebulun genealogy; see Sara Japhet, The Ideology of the Book of Chronicles and its Place in Biblical Thought (trans. Anna Barber; Winona Lake, IN: Eisenbrauns, 2009 [1977]), 219n60-61; and Edward L. Curtis and Albert A. Madsen, The Books of Chronicles (ICC; Edinburgh, 1910), 145-149. However, Knoppers (1 Chronicles 1-9, 459) and Klein (1 Chronicles, 220-221) are skeptical of these theories, arguing that they require too much implausible textual emendation.

${ }^{18}$ According to the NRSV: Abdon, Abihud, Abijah, Abinadab, Abishua, Abitub, Adaiah, Addar, Aharah, Ahaz, Aher, Ahihud, Ahijah, Ahio, Ahishahar, Ahoah, Aijalon, Alemeth, Anathoth, Anthothijah, Arad, Ashbel, Athaliah, Azel, Azmaveth, Azrikam, Baal, Baara, Becher, Bela, Beraiah, Beriah, Bilhan, Binea, Bocheru, Chenaanah, Eber, Eder, Ehud, Elam, Eleasah, Eliel, Elienai, Eliezer, Elijah, Elioenai, Eliphelet, Elpaal, Esh-Baal, Eshek, Ezbon, Gedor, Gera, Hanan, Hananiah, Heber, Heglam, Hizki, Hodesh, Huppim, Huram, Hushim, Hushim, Iphdeiah, Ir, Iri, Ishmael, Ishmerai, Ishpah, Ishpan, Izliah, Jaareshiah, Jakim, Jediael, Jehoaddah, Jeiel, Jeremoth, Jerimoth, Jeroham, Jeush, Jeuz, Joash, Jobab, Joha, Jonathan, Kish, Maacah, Malcam, Malchishua, Melech, Merib-baal, Mesha, Meshullam, Micah, Michael, Mikloth, Mirmah, Misham, Moza, Naaman, Nadab, Ner, Nohah, Obadiah, Omri, Penuel, Pithon, Rapha, Raphah, Sachia, Shaharaim, Shamsherai, Shashak, Sheariah, Shehariah, Shema, Shemed, Shephuphan, Shimeah, Shimei, Shimrath, Shuppim, Tarea, Tarshish, Ulam, Uzza, Uzzi, Uzziel, Zabdi, Zebadiah, Zecher, Zemirah, Zethan, Zibia, Zichri, Zillethai, Zimri, and Zur. 
- The list of David's mighty men includes ten names from the Benjaminite lists that refer to persons of uncertain tribal origin (11:33-34, 36, 43-47). ${ }^{19}$ Since other unambiguously Benjaminite figures are named among David's mighty men (Ittai and Abiezer, as discussed previously), the "message" of the passage for Benjamin (i.e., Benjaminites were numbered among David's most trusted supporters) would not change very much if these men are understood as Benjaminite.

- The description of David's administrative and military hierarchy includes six names from the Benjaminite lists that refer to persons of uncertain tribal origin: Mikloth (1 Chr 27:4), Azmaveth (27:25), Jonathan son of Uzziah (27:25), Shimei the Ramathite ${ }^{20}$ (27:27), Zabdi the Shiphmite (27:27), and Joash (27:28). Along with these persons are ten names from the list that are clearly not Benjaminites in this context, and one Benjaminite who is explicitly identified by the context (Abiezer; 27:12).

- A certain Obadiah is one of Jehoshaphat's officials (2 Chr 17:7).

- Zedekiah, a prophet, is called the son of Chenaanah (2 Chr 18:10).

- Eliezer son of Dodavahu of Mareshah prophesies against Jehoshaphat's sea venture (2 Chr 20:37).

- Four names (Jeroham, Ishmael, Adaiah, Zichri) appear in the list of army commanders (some as fathers of the men in question) who were loyal to Jehoiada ( $2 \mathrm{Chr} 23: 1){ }^{21}$

- Uzziah has a secretary named Jeiel and a commander named Hananiah (2 Chr 26:11).

- Azrikam was "prince of the palace" (נגיד הבית) of Ahaz (2 Chr 28:7).

- Abdon son of Micaiah ${ }^{22}$ is one of Josiah's officials (2 Chr 34:20).

Of the "possible" Benjaminites listed, most are understood in a positive or neutral light. The exceptions would be Zedekiah, whose prophecy turned out to be untrue (2 Chr 18:23-24), and Azrikam, who is killed in the Northern invasion (2 Chr 28:7).

It is not at all conclusive that the fact that these minor characters' names are included in the Benjaminite genealogies of 1 Chronicles 7:6-12 and 8:1-40 should have any bearing on the

${ }^{19}$ Azmaveth, Jonathan, Ahijah, Hanan, Maacah, Jeiel, Jediael, Joha, and Eliel (twice). Interestingly, only "Azmaveth" has been taken over from the Vorlage (2 Sam 23:31-39).

${ }^{20}$ See the discussions of the tribal affiliations of the various places called "Ramah": $\$ 4.2 .4, \S 5.2 .3, \S 5.3 .4$, $\S 5.4 .1, \S 5.5 .2 .3$.

${ }^{21}$ No commander is mentioned by name in $2 \mathrm{Kgs} 11: 4$ ("Jehoiada summoned the captains of the Carites and of the guards and had them come to him in the house of the LORD").

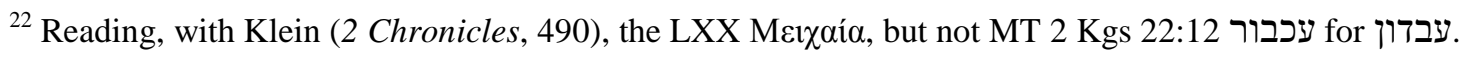


interpretation of these characters as Benjaminites - or whether the identification of such characters as Benjaminites changes the implications of the narratives to any significant degree. Genealogies seem to reflect the ancient author's perception of the relation of individuals and groups through the use of telescoping vertical lineages, incomplete family branches, non-exhaustive lists, and the grouping of certain family/tribal names. One might imagine that an ancient hearer/reader of Chronicles might have been attuned to the use of names that were common in his tribe-and he might be less concerned about whether the generations of the genealogies could be synchronized with references in the narrative passages. In other words, simply the occurrences of "Benjaminite" names in the narrative (along with other more obvious Benjaminites) would signal the inclusion of Benjamin in Chronicles, whether or not the characters are "in fact" Benjaminite. ${ }^{23}$

\subsubsection{Summary}

The characterization of Benjaminite individuals and groups in Chronicles tends to be favorable or neutral. Most individuals are minor characters in the narratives. The majority of references to Benjaminites in Chronicles occur in the Sondergut. This may indicate that the Chronicler sought to reshape the presentation of Benjamin in his retelling of Israel's monarchic history.

Saul, the most important Benjaminite in Samuel-Kings, receives very little treatment in Chronicles. Saul is isolated at the beginning of the narrative and belongs to the pre-Davidic era, which is not the Chronicler's focus. Nevertheless, Saul's line continues many generations after his death through his grandson, Merib-baal.

In Chronicles, Benjaminites continue to play an important role in Israel in the service of Judahite kings. Many Benjaminites are portrayed as crucial in David's rise and the establishment of his kingdom. Benjaminites are prominent in administration and the military.

Interestingly, Chronicles adopts from the Primary Narrative the characterization of a subset of Benjaminites as left-handed or ambidextrous, and as skilled with the bow and/or sling. But the stereotype manifests itself in the Sondergut material, and the Chronicler has not included any of the DtrH passages that contribute to these characterizations (or from which these characterizations are derived).

\subsubsection{Benjaminite Places}

Benjaminite places receive relatively little attention in Chronicles, which bypasses the portions of Israel's pre-monarchic and early-monarchic history that are set in Benjaminite territory.

\footnotetext{
${ }^{23}$ See Yigal Levin, "Who Was the Chronicler's Audience? A Hint from His Genealogies,” JBL 122 (2003):
} 231-233. 
Of the locales that are mentioned as belonging to Benjamin—except for Jerusalem/Jebus-eleven are mentioned in Chronicles in twenty-eight verses/passages (see Appendix: Table 4). Seven such verses/passages are located in the genealogies. Four additional verses/passages reference Jebus, the Canaanite name of the city that became Jerusalem.

Jonker makes several pertinent observations concerning the Chronicler's lack of narrative references to Benjaminite places. First, Bethel and Mizpah are mentioned only once each. The statement that Asa used the stones from Ramah to fortify "Geba and Mizpah" (2 Chr 16:6) is taken over from the Vorlage (1 Kgs 15:22). The lone reference to Bethel is found in the Sondergut, and places Judah's capture of that city from the Northern Kingdom in the time of Jeroboam and Abijah (2 Chr 13:19). ${ }^{24}$ Second, Jonker remarks that Gibeah is mentioned only once, but it is actually twice if the construct form in 1 Chronicles 11:31 is counted (מגבעת בני בנימן). The other reference (2 Chr 13:2) is found in the Sondergut, but Jonker observes that this verse

\begin{abstract}
...is not the Chronicler's own addition; it is, rather, a compendium of information that appears in 1 $\operatorname{Kgs}$ 15:2, 6, and 7. The Chronicler added to these verses the point that Jeroboam's mother was the daughter of Uriel of Gibeah. 1 Kgs 15:2, however, states, "His mother's name was Maacah daughter of Abishalom" (NRSV). ${ }^{25}$
\end{abstract}

Gibeon is referenced five times in the narrative, four times as the location of the tent of meeting (1 Chr 16:39; 21:29; 2 Chr 1:3, 13). Additionally, 1 Chronicles 14:16 changes the extent of David's defeat of the Philistines to, "from Gibeon to Gezer" (cf. 2 Sam 5:25: "from Geba to Gezer"). ${ }^{26}$ Klein suggests that the Chronicler hereby clears the way for the ark's ascent to Jerusalem, and also clarifies that the tabernacle is secure at Gibeon (cf. 1 Chr 16:39). ${ }^{27}$ After Solomon's consolidation of the ark and the tent into the temple, Gibeon is not mentioned subsequently in Chronicles.

Other narrative references to places with historic Benjaminite connection include: Ramah (2 Chr 16:1-6; 22:6), Jericho (1 Chr 19:5, 2 Chr 28:15), Mount Zemaraim (2 Chr 13:4); Anathoth, a Levitical city within Benjamin (1 Chr 11:28; 12:3; 27:12; cf 6:60 [MT 6:45]); and Aijalon, another Levitical city, formerly of the Philistines (1 Chr 6:69 [MT 6:54]; 8:13; 2 Chr 11:10; 28:18). Ramah

${ }^{24}$ Jonker, “Of Jebus, Jerusalem and Benjamin,” 87.

${ }^{25}$ Jonker, “Of Jebus, Jerusalem and Benjamin,” 87.

${ }^{26}$ The change does not appear to be a text-critical issue; Knoppers, 1 Chronicles 10-29, 597; Klein, 1 Chronicles, 338.

${ }^{27}$ Klein, 1 Chronicles, 343. See also Joseph Blenkinsopp, Gibeon and Israel: The Role of Gibeon and the Gibeonites in the Political and Religious History of Early Israel (SOTSMS 2; New York: Cambridge University Press, 1972), 100-104. 
is a border city between Northern Kingdom and Judah, a point of contention. Zemaraim is the site of a Sondergut royal speech and miraculous victory. Jericho is the point of return for the Southern captives who are shown mercy by their Samarian captors (2 Chr 28:15).

\subsubsection{Jebus/Jerusalem}

The importance of Jebus/Jerusalem in both the DtrH and Chronicles as a strategic location between Judah and Benjamin ${ }^{28}$ has featured prominently in this study $(\S 2.3 .3, \S 5.2 .3, \S 5.4 .2 .4$, etc.), and much remains to be discussed in this regard. In a sense, all the narrative sections of Chronicles that are set in Jerusalem - a large portion of Chronicles-are set in Benjaminite territory, or at least territory that was traditionally Benjaminite.

1 Chronicles 21, the Chronicler's reworking of the census narrative (2 Sam 24), is quite revealing. Two recent contributions by $\mathrm{Amit}^{29}$ and Jonker ${ }^{30}$ discuss the significance of this passage in the Chronicler's attempt to shape the historical memory of his audience in relation to tribal relations and disputes over Jerusalem and other cultic sites.

Several relevant differences between the two narratives are immediately apparent. First, 2 Samuel 24 is part of a compendium of stories appended to the end of Samuel, and cannot be definitively placed in the chronology of David's reign. By contrast, 1 Chronicles 21 is used to launch a section that contains David's testament and his preparations for the temple construction, which is his magnum opus. ${ }^{31}$

Second, the Chronicler makes two changes to the census account pertaining to geography. He omits the description of Joab's Northern route in conducting the census (2 Sam 24:5-8a), opting for the phrase "all Israel" (1 Chr 21:4). This may indicate that the Chronicler considered the details to be irrelevant or incomprehensible ${ }^{32}$ - but Jonker suggests:

This term [כל ישראל] that appears so frequently in the Chronicler's Sondergut is a prominent reflection of the self-definition that the Chronicler wanted to attribute to the community that returned to Yehud after the exile. The use of this term should therefore not be seen merely as an abbreviation of the Deuteronomistic version but as having significance in itself within the broader scope of Chronicles. ${ }^{33}$

${ }^{28}$ To summarize: the city of Jebus/Jerusalem is listed in Benjamin's allotment (Josh 18:28; cf Jdg 1:21), but also mentioned as a border of Judah's allotment (Josh 15:8) and as a (partial) possession of Judah at some point in time (Josh 15:63).

${ }^{29}$ Yairah Amit, “Araunah's Threshing Floor: A Lesson in Shaping Historical Memory,” in What Was Authoritative for Chronicles? (ed. Ehud Ben Zvi and Diana Edelman; Winona Lake, IN: Eisenbrauns, 2011), $133-144$.

${ }^{30}$ Jonker, "Of Jebus, Jerusalem and Benjamin."

${ }^{31}$ Amit, “Araunah's Threshing Floor,” 134-136.

${ }^{32}$ Klein, 1 Chronicles, 421.

${ }^{33}$ Jonker, “Of Jebus, Jerusalem and Benjamin,” 89. 
The Chronicler also adds that Joab excluded Levi and Benjamin from the census (21:6). Japhet argues that this change prevents Levi and Benjamin from bearing the consequences of David's sin, and sets the stage for Jerusalem - a city already linked to Benjamin and later linked to Levi through the cult- to be guiltless and, moreover, the place where the guilt of "all Israel" is expunged. ${ }^{34}$

Third, the Chronicler adds significantly to David's purchase from Araunah/Ornan. In 2 Samuel 24:24, David purchases the threshing floor (הגרן) and the oxen for fifty shekels of silver. The Chronicler records that David purchased "the [whole] site of the threshing floor" (מקום הגרן) and the oxen for six hundred shekels of gold (21:22-25).

Fourth, the drama of YHWH's answer to David's act is also heightened by the Chronicler: whereas 2 Samuel 24:25 notes only that "YHWH was moved by the prayer for the land, and the plague was withdrawn from Israel," the Chronicler adds that YHWH answered by fire and commanded the angel to withdraw his sword (21:26-27). This dramatic response frightens David and convinces him that this site in Jebus, rather than the tabernacle at Gibeon, is now the proper location for prayers to YHWH (21:28-22:1).

Amit argues that these changes to the 2 Samuel 24 narrative convert the story from "an unfocused etiological story" to "a focused hieros logos." 35 Whereas the readers of 2 Samuel would perhaps be expected to assume that Jerusalem is "the place in which YHWH will set his name to dwell there" based on the three disparate etiologies of its status (as David's capital: 2 Sam 5:6-9; as home of the ark: 6:1-19; as site of an altar: 24:1-25), the Chronicler makes explicit his belief that YHWH guided David to this very location for the temple.

As discussed previously ( $\$ 2.3 .3)$, the Chronicler is able through these changes to assert that Jerusalem and its cult belong equally to Judah, Benjamin and Levi. ${ }^{36}$ By linking Benjamin "historically" to the Jerusalem cult, the Chronicler also cleverly excludes Benjaminite traditional cultic sites, such as Bethel and Gibeon:

By claiming that this exact site is the place where the sanctuary should be built, the Chronicler establishes neutral terrain for the temple site.... Jebus now becomes the Chronicler's trump card to play over against any Benjaminite claim to authority. ${ }^{37}$

${ }^{34}$ Sara Japhet, I \& II Chronicles: A Commentary (Old Testament Library Series; Louisville: Westminster John Knox Press, 1993), 378. See also Jonker, “Of Jebus, Jerusalem and Benjamin,” 93.

35 Amit, "Araunah's Threshing Floor," 136-137.

${ }^{36}$ Louis C. Jonker, "Engaging with Different Contexts: A Survey of the Various Levels of Identity Negotiation in Chronicles," in Texts, Contexts and Readings in Postexilic Literature (ed. Louis C. Jonker; Tübingen: Mohr-Siebeck, 2011), 79.

${ }^{37}$ Jonker, "Engaging with Different Contexts," 79-80. 
Therefore, it is reasonable to suggest that, in the Chronicler's mind, all of his narratives that are set in Jerusalem relate equally to Benjamin in addition to Levi and Judah. The Chronicler goes to great lengths elsewhere to encompass members of the wayward Northern tribes within "all Israel." In his time, however, attempting to draw Benjaminites toward Jerusalem was a much more realistic application of his "all Israel" rhetorical goal than attempting to draw the other tribes, given the proximity of Benjamin to Jerusalem and the closer political ties between Benjamin and Judah historically.

\subsubsection{Summary}

The Chronicler's treatment of Benjaminite locations makes several contributions to our understanding of the Chronicler's stance toward Benjamin. First, many of the Chronicler's references to uniquely Benjaminite locations are paired with names of persons (demonyms). Those Benjaminite persons, as we have seen, are minor characters in the narrative but indicate the presence of Benjaminites in high administrative and military positions.

Second, some references to Benjaminite locations are in the contexts of military gains, losses, and fortifications by Judahite kings - the locations are not themselves settings in the narratives. The underlying assumption is that Benjamin is part of the territory of Judahite kings; the towns do not constitute a separate political entity within Judah, but individuals and towns do retain Benjaminite identity.

Third, no Benjaminite locations are the focus of cultic activity, except for Gibeon. Bethel and Mizpah, which apparently housed Yahwistic cults during several periods, are virtually absentthey are merely part of Benjamin, which is part of the kingdom of Judah. Gibeon is only present in the narrative so long as the tent of meeting is located there-after Solomon resolves to build the temple, Gibeon disappears.

Finally, the Chronicler's paucity of references to Benjaminite places, paired with his generally positive view of Benjamin and Benjaminites, lends support to the notion that the Chronicler actually considers Jerusalem itself (more precisely, the site of the temple) to be part of Benjaminite territory—or at least, common to Judah and Benjamin. Thus, all the royal and cultic activity that takes place in Jerusalem in Chronicles is relevant to Benjamin.

\subsubsection{Summary: Benjamin in Chronicles}

The references to Benjamin, Benjaminites, and Benjaminite places in Chronicles are consistent with the book's narrow focus on the public lives of Judahite kings and the religious activities and responsibilities of the Levitical families. 
- Characters from tribes other than Judah and Levi—including Benjaminites—recede into the background.

- After the division of the kingdom, the Northern tribes collectively retreat from the Chronicler's purview_-but Benjamin remains a relevant collective identity, as evidenced by the numerous references to "Benjamin" and "Benjaminites" in 2 Chronicles. Benjamin remains the primary constituent tribe of "all Israel" beside Judah and Levi.

- Benjaminites are prominent in all sections of Chronicles, serving in important administrative and military positions.

- Uniquely Benjaminite locations receive less attention because they have no cultic significance for the Chronicler.

- It is implied that the Jerusalem temple belongs equally to Judah, Benjamin and Levi, being located on the border between the territories of the first two tribes and administered by the third.

\subsection{BENJAMIN IN THE SECTIONS OF CHRONICLES}

This section will address the portrayal of Benjamin and Benjaminites in the contexts of the literary units within Chronicles, with particular attention to the Chronicler's use of the Vorlage.

\subsubsection{Genealogies (1 Chr 1-9)}

The novice reader of Chronicles, having consulted commentaries on Chronicles that emphasize the importance of synoptic comparisons to Samuel and Kings, may be surprised to discover that the first nine chapters of Chronicles do not actually contain material derived from Samuel-Kings. The date and provenance of 1 Chronicles 1-9 are widely debated. ${ }^{38}$ In accordance with the approach taken elsewhere in this study, this section will consider the structure and purpose of 1 Chronicles 1-9 in the context of the received form of the book of Chronicles, with particular attention to the relationship between the Benjaminite material and the contribution of the genealogies to the argument of Chronicles.

${ }^{38}$ Israel Finkelstein lists many of the most important works in a recent essay: "The Historical Reality Behind the Genealogical Lists in 1 Chronicles," JBL 131 (2012): 65-83. For his own part, Finkelstein argues that if the sites listed in the genealogies of $1 \mathrm{Chr} 2-9$ reflect "a given, genuine moment in history," then that moment would be the Hasmonean period (83). It remains to be seen whether Finkelstein's suggestion will receive wider acceptance. 
Many scholars have discerned a concentric (chiastic) structure within the genealogies. ${ }^{39}$ Bracketing the genealogy of "all Israel" (1 Chr 2:3-9:1) are the nations of the world (1:1-2:2) and the account of Israel among the nations in the post-exile (9:2-34). Within the genealogy of "all Israel" are concentric rings that create the following corresponding pairs around Levi at the center (6:1-81 [MT 5:27-6:66]): Judah and Simeon (2:3-4:43) corresponding to Benjamin (8:1-40); and the Transjordan tribes (5:1-26) corresponding to the Northern tribes (7:1-40).

Several remarkable features of 1 Chronicles 1-9 relate to Benjamin. First, the chiastic structure of the genealogy of "all Israel" (2:3-9:1) focuses attention on the substantial genealogies at the beginning, middle and end-Judah, Levi and Benjamin. Klein observes that the genealogies of these three tribes are the longest, with Judah's list spanning one-hundred verses, Levi's list totaling eighty-one verses, and Benjamin's lists combining for a total of fifty-seven verses (7:6-12; 8:1-40; 9:35-44). ${ }^{40}$ Knoppers observes, "In an era in which kinship relations and the question of ancestry were of great consequence for determining status and self-identity, the prominence of Benjamin is striking," ${ }^{41}$ and, "The due attention given to Benjamin's many descendants supports and ratifies the prominence of this group in Persian period Judah."42 Jonker claims, "It is clear that the Chronicler's genealogical introduction is intended to claim equal status between Judah and Benjamin." 43 It is apparent that Judah and Levi claim special status as the tribes of David and the high priests, but Benjamin complements these two tribes and forms the fitting "conclusion" of "all Israel"-last, but certainly not least.

${ }^{39}$ Jonker, "Of Jebus, Jerusalem and Benjamin," 85-86; Knoppers, 1 Chronicles 1-9, 260-265; Klein, 1 Chronicles, 86-87. See James T. Sparks, The Chronicler's Genealogies: Towards an Understanding of 1 Chronicles 1 9 (Atlanta: SBL, 2008), 23-32, for a discussion of the criteria for identifying and interpreting chiasm in this section and elsewhere in the Hebrew Bible.

Manfred Oeming (Das wahre Israel: Die “geneologische Vorhalle” 1 Chronik 1-9; BWANT 128; Stuttgart: Kohlhammer, 1990) acknowledges a sort of chiastic structure within 1 Chr 2-8, but prefers to think of 1 Chr 1-9 overall as a progression of concentric circles of holiness (world-Israel-Jerusalem-temple): "Dem Aufriß liegt ein wohldurchdachtes Modell konzentrischer Heiligkeit zugrunde: Den ersten äusseren Kreis bildet die Völkerwelt mit dem Zentrum Israel; den zweiten Kreis bilden die Stämme Israels mit den eindeutigen Schwerpunkten Juda, Levi, Benjamin, wobei Levi in der Mitte steht; der dritte Kreis ist Jerusalem mit seinen Bewohnern, wobei im Zentrum der Tempel, die Wohnung Jahwes, und sein Personal steht” (210, emphasis original).

${ }^{40}$ Klein, 1 Chronicles, 86.

${ }^{41}$ Gary N. Knoppers, "Israel's First King and 'the Kingdom of YHWH in the hands of the sons of David': The Place of the Saulide Monarchy in the Chronicler's Historiography," in Saul in Story and Tradition (ed. Carl S. Ehrlich and Marsha C. White; FAT 47; Tübingen: Mohr-Siebeck, 2006), 207.

\footnotetext{
${ }^{42}$ Knoppers, 1 Chronicles 1-9, 492.

${ }^{43}$ Jonker, "Of Jebus, Jerusalem and Benjamin," 86.
} 
Three features of the genealogies pertain to the so-called "Northern" tribes. First, the Chronicler has taken pains to ensure that the tribes total twelve-plus-Levi-even though this involves the exclusion of Dan and Zebulun, and counting Manasseh and Benjamin twice each (5:23-24 and 7:14-19; 7:6-12 and 8:1-40). Simeon is also retained as a distinct tribe, though this territory was likely absorbed into Judah before the Chronicler's time. ${ }^{44}$ The Chronicler's "creative" way of counting to twelve represents his "all Israel" ideal, which was certainly more ideal than reality in his own day. Second, setting the Northern and Transjordan tribes inside the inclusio formed by Judah and Benjamin emphasizes their importance to the integrity of "all Israel." Third, Benjamin is listed among the "Northern" tribes (7:6-12). Rather than constituting an edited or corrupted listing of Zebulun or Dan, ${ }^{45}$ this brief listing of Benjamin ties this "Southern" tribe partly to the north, acknowledging the likely historical reality of the divided monarchy. The inclusion of Benjamin among the Northern tribes balances the close association with Judah created by the chiasm. $^{46}$

In addition to Benjamin's important placement in the listing of "all Israel" (2:3-9:1), Benjaminites figure prominently in the listing of the returning golah community. The Chronicler calls the returnees "Israel, the priests, the Levites, and the temple servants" $(9: 2) ;{ }^{47}$ the inhabitants of Jerusalem are said to include "some of the sons of Judah, the sons of Benjamin, and the sons of Ephraim and Manasseh" (9:3)— though only Judahites, Benjaminites and Levites are counted and

${ }^{44}$ Knoppers, 1 Chronicles 1-9, 372.

${ }^{45}$ See the discussion in $\$ 6.2 .2 .3 \mathrm{n} 17$ above.

${ }^{46}$ Regarding $1 \mathrm{Chr} 8$, Knoppers argues, "Counter to some earlier biblical texts in which Benjamin is associated with the northern tribes"—-for example, 1 Chr 7:6-12! — "the Chronicler postulates close ties between Judah and Benjamin. In spite of the crisis created by the northern secession, Benjamin, together with Judah and Levi, remains loyal to the normative institutions established during the United Monarchy (2 Chr 11:1-4, 13-17; 13:4-12)" (1 Chronicles 1-9, 491).

${ }^{47}$ Blenkinsopp suggests a connection between the "non-Israelite" Gibeonites and the נתינים (usually translated "temple servants") in 1 Chr 9:2, Ezr 2:43ff., Neh 11:3 and elsewhere (Gibeon and Israel, 106-108). He postulates, "Once the Gibeonite sanctuary had been definitely eclipsed by its rival in Jerusalem, it is entirely probable that Gibeonites and other ethnic groups were used for the many menial tasks involved in the sacrificial cultus, and the phrase 'hewers of wood and drawers of water' would be consistent with such occupations" (Gibeon and Israel, 107). He supports the connection between the נתינים and Gibeon with the observation that $1 \mathrm{Chr} 9$ concludes its outline the returning golah community with a restatement of the Gibeonite genealogy (9:35-44).

Blenkinsopp's theory, while intriguing, is difficult to prove conclusively, given the complexities surrounding the "ethnic" identities of the returnees and the she'erit communities in the early Persian period. Also, as discussed below, the repetition of the Gibeonite genealogy at the end of $1 \mathrm{Chr} 9 \mathrm{might}$ be better understood as a segue to the Saul narrative rather than as a statement of the identity of some of the temple servants (9:33), as Blenkinsopp suggests. 
named (9:4-34). The "all Israel" ideal is therefore retained, but Benjamin is a crucial part of the manifested reality of "all Israel."

Finally, the genealogical section of Chronicles concludes with ten verses repeating the genealogy of Jeiel (9:35-44//8:29-38). The mere fact that this section concludes with a Benjaminite genealogy is striking. Knoppers observes, "Along with the Davidic genealogy (1 Chr 3:1-24) and the Kohathite priestly genealogy (1 Chr 5:27-41), the genealogy of this ancestor of Saul is one of the longest in the Hebrew Bible," extending fifteen generations. ${ }^{48}$ The purpose may be to create a link between the Chronicler's post-exilic era (9:2-34) and the Saul narrative (10:1-14). ${ }^{49}$ As will be discussed in greater detail below in relation to Saul, this genealogical link from the Chronicler's present to his past underscores the importance of Benjamin in the Chronicler's era and distances the tribe as a whole from the failures of Saul the individual. ${ }^{50}$

In summary, the genealogical section of Chronicles establishes the importance of Benjamin in two important respects: as a crucial component of the "all Israel" ideal, and as an equal constituent of Yehud in the Persian period. As the only "other" tribe beside Judah and Levi, the tribe of Benjamin is the only tangible realization of the ancient "all Israel" ideal in the Chronicler's own day. For this reason, Benjamin is held in high esteem by the Chronicler. This esteem pervades the narrative of Chronicles: Benjaminites are repeatedly presented as performing the proper functions of "all Israel" - sometimes along with members of other tribes, but sometimes as the lone representative of "all Israel."

\subsubsection{Reign of David (1 Chr 10-29)}

The Chronicler's account of the rise and reign of David constitutes twenty chapters and parallels twenty-seven chapters in the DtrH (1 Sam 31; 2 Sam 1-24; 1 Kgs 1-2). However, ten of the Chronicler's twenty chapters on David's reign are predominantly or exclusively comprised of Sondergut material (1 Chr 12; 16; 22-29) —and nineteen of the Deuteronomist's twenty-seven chapters are mostly or completely unrepresented in Chronicles (2 Sam 1-4; 9; 11-20; 21:1-14; 22; 1 Kgs 1-2). Additionally, the Chronicler has reordered some of the source material. Each of these categories - sections common to both works, or unique to either the DtrH or Chronicles-contains significant Benjaminite material.

${ }^{48}$ Knoppers, “Israel's First King,” 207-208.

${ }^{49}$ Knoppers treats 9:35-10:14 as a unit in his commentary (1 Chronicles 10-29, 515-531). See also Klein, 1 Chronicles, 281.

${ }^{50}$ Klein argues, “....Genealogical material in chap. 9 prepares for the beginning of the Chronicler's narrative with the death of Saul. It also indicates that while Saul's family suffered a severe blow at Gilboa, the whole family was not wiped out, least of all by David....However unfaithful the Benjaminite Saul had proven to be, the indictment against him did not make all the members of his tribe guilty" (1 Chronicles, 281). 


\subsubsection{Saul's Death and David's Rise (1 Chr 10-12)}

That the Chronicler chose to begin his narrative with an account of Israel's only Benjaminite king is quite significant for understanding the Chronicler's stance toward Benjamin. But the exact nature of the role of 1 Chronicles 10 in the Chronicler's argument has been the subject of much debate. Does the Chronicler assume that his audience knows 1 Samuel, and does he intend to import the Deuteronomist's account and assessment of Saul into this new context? Is the Saul narrative part of the story of David's rise, or is it a self-contained narrative that contrasts with the account of David? If the Chronicler's primary purpose is to draw a contrast between David and the poor administration of the preceding eras, why did he not choose to begin his narrative earlier in Saul's career, or in the period of the judges ${ }^{51}$

Knoppers argues that the Chronicler has carefully chosen to include this account of Saul's death (and to add the assessment of Saul's kingship; 1 Chr 10:13-14) in order to reconfigure the overlap of David's rise and Saul's downfall. ${ }^{52}$ In this view, the Chronicler recognizes that Saul is an important component of the story of the monarchy, not just a foil for David—and thus Saul's pedigree and his sons are included (9:35-10:2). ${ }^{53}$ But the Chronicler is concerned to absolve David of any perceived complicity in the downfall of Saul's house; therefore, he must disentangle the fates of the two figures. ${ }^{54} \mathrm{He}$ accomplishes this dissociation by reshaping the chronology of the events and by omission of narratives that connect David to Saul's house. Both of these techniques will be discussed in greater detail below (\$6.4.1).

In the Chronicler's presentation, “all Israel” crowns David immediately upon Saul's death. No mention is made of a civil war with Ishbosheth/Eshbaal, Benjamin and the Northern tribes. Rather, Benjaminites and Northerners (and foreigners) are included in David's mighty men, which the Chronicler moves from an appendix (2 Sam 23:8-39) to the beginning of David's reign (1 Chr 11:10-47). While Saul was still king, David led Israel (1 Chr 11:2) and was attracting support from all tribes, including Benjaminites from Saul's own clan (1 Chr 12:1-7, 16-18, 29 [MT 12:1-8, 1719, 30]).

In 1 Chronicles 10-12, the Chronicler takes great pains to isolate his assessment of Saul from the otherwise positive presentation of Benjaminites, who are integral members of David's early support (1 Chr 11). Benjaminites are listed first among David's supporters at Ziklag (12:1ff).

\footnotetext{
${ }^{51}$ Knoppers discusses at least four sorts of approaches to these questions (“Israel's First King,” 189-193).

${ }^{52}$ Knoppers, “Israel's First King," 192.

${ }^{53}$ Knoppers, “Israel's First King," 192.

${ }^{54}$ Knoppers, “Israel's First King," 192.
} 
In Chronicles, as in 2 Samuel 5, David's first act as king of "all Israel" is to capture Jebus. As discussed, the Chronicler's choice to highlight David's establishment of a capital on the border between Judah and Benjamin may reflect a conciliatory tone for his work.

\subsubsection{Bringing up the Ark (1 Chr 13-16)}

This section of Chronicles supplements, modifies and rearranges material from 2 Samuel 5:11-6:23. Most notably, the Chronicler splits the narrative of the ark's ascent to Jerusalem (2 Sam 6:1-19a) into two attempts, and inserts material concerning the establishment of David's house and his military victories (2 Sam 5:11-25) between the two narratives. The Chronicler also adds quite a bit of material: an account of the Levites and elders who accompany the ark, and a song attributed to David for the occasion.

Several Benjaminite elements are notable. In a preface to the initial attempt to bring the ark to Jerusalem, David remarks that the people had "not sought [the ark] in the days of Saul" (11:3). As discussed, this remark (and the people's affirmation: 11:4b) casts aspersion on Saul as a leader.

The Chronicler adopts from the Vorlage the statement that Michal, daughter of Saul, despised David for dancing (1 Chr 15:29//2 Sam 6:16). However, the Chronicler omits the later discussion between Michal and David (2 Sam 6:20-23). These references will be discussed in greater detail below (\$6.4.1.5), but this appears to serve the Chronicler's purpose of distancing the houses of David and Saul from one another, and isolating guilt upon Saul's house rather than upon Benjamin as a whole.

The choice of Jerusalem as the location for the ark is significant for Benjamin, as well. In Samuel, David acts autonomously to bring the ark to himself (2 Sam 6:1-2a, 9, 12a). The Chronicler's accounts of the attempts to transport the ark are sprinkled with the phrase "all Israel" $(13: 5,6,8 ; 15: 3,28$-all Sondergut), emphasizing the unanimity of the decision to move the ark to Jerusalem.

Two references to Gibeon have been added to the Vorlage. As discussed previously (\$6.2.3), 1 Chronicles 14:16 reads "Gibeon" for "Geba" (2 Sam 5:25), which may be interpreted as the Chronicler clarifying that the tabernacle is secure at Gibeon. ${ }^{55}$ After situating the ark in Jerusalem, David appoints Zadok the priest to remain in Gibeon to minister at the tabernacle (16:39).

\footnotetext{
${ }^{55}$ Klein, 1 Chronicles, 343.
} 


\subsubsection{Establishment and Extension of David's Kingdom (1 Chr 17-20)}

1 Chronicles 17-20 is more remarkable for the Benjaminite content that is omitted from the Vorlage than for anything that is included. ${ }^{56}$ The Chronicler "adds relatively little to the material he draws from Samuel," nor does he reorder the material he retains. ${ }^{57}$

The explicit reference to Saul in the context of YHWH's promise to David (2 Sam 7:15) is made implicit (1 Chr 17:13). The Chronicler further distances David from the house of Saul by bypassing the Mephibosheth (Merib-baal) narrative (2 Sam 9).

Even more significant is the omission of the narratives of David's troubles (2 Sam 13:121:17), in which Benjaminites play significant roles (Mephibosheth, Ziba, Shimei, Sheba, Saul's grandsons). Synoptically, these chapters would be placed between 1 Chronicles 20:3 (2 Sam 12:31) and 20:4 (2 Sam 21:18), ${ }^{58}$ though it is not clear that the events of 2 Samuel 21-24 are intended to be read as chronologically subsequent to the events of the rest of the book. The Chronicler has, for various reasons, completely expunged these events (and the sin with Bathsheba: 2 Sam 11:2-12:25), and used the isolated narrative of the census (2 Sam 24) as the introduction to the (now peaceful and prosperous) twilight years of David's reign (1 Chr 21-29).

It would be a stretch to argue that a pro-Benjamin slant—rather than a pro-David agendamotivated these omissions. Yet from the perspective of this study, it is notable that the Chronicler replaces a narrative of David's latter years that portrays individual Benjaminites (Saulides in particular) in a poor light, with a narrative in which David providentially discovers that the temple should be built on the border between Judah and Benjamin.

\subsubsection{The Census, Temple Preparations, and David's Testament (1 Chr 21-29)}

The last nine chapters of 1 Chronicles are quite significant for the presentation of Benjamin, including material adapted from the Vorlage, material omitted from the Vorlage, and the Sondergut. The Chronicler uses the census narrative (2 Sam 24//1 Chr 21) as a crucial introduction to David's preparations for the temple and for Solomon's succession (1 Chr 22-29), which is radically altered from 1 Kings 1-2—with significant implications for Benjamin.

As discussed (\$6.2.3.1), the Chronicler’s adaptation of the census narrative establishes the temple site in Jebus on the border between Benjamin and Judah, and exempts Benjamin and Levi from any negative consequences of David's sin. ${ }^{59}$ In the present section, it is important to emphasize that the Chronicler has not only added a pro-Benjamin slant to the story but also placed

\footnotetext{
${ }^{56}$ The Chronicler does retain a single reference to Jericho from 2 Sam 10:5 (1 Chr 19:5).

${ }^{57}$ Knoppers, 1 Chronicles 10-29, 739.

${ }^{58}$ See the outline by Knoppers, 1 Chronicles 10-29, 738.

${ }^{59}$ See also Knoppers, 1 Chronicles 10-29, 752-753.
} 
the story at the center of his narrative of David's reign. Knoppers calls 1 Chronicles 21:1-22:1 "a crux interpretum in the Chronicler's depiction of an illustrious reign. ${ }^{60}$ Knoppers views this narrative not as a puzzling blemish on David's character that somehow evaded the Chronicler's whitewashing, but rather as a positive presentation of David as an exemplary king who models confession, repentance, intercession, obedience, and divine blessing: ${ }^{61}$

David's unequivocal admission of guilt, his mediation on behalf of Israel, his diligent observance of divine instructions, and his securing a site for the future Temple contribute positively to his legacy. ${ }^{62}$

The narrative of the census is followed by David's preparations for the building of the temple (22:2-19), his delegation of its administration (23-26), his military and administrative provision for Solomon's kingdom (27), and his promotion of Solomon to the throne (28-29). Saul's and Abner's war spoils contribute to the temple treasury (26:28), ${ }^{63}$ and Benjaminites occupy high positions in the administrative hierarchy $(27: 12,21 b)$.

The smooth transfer of power from a respected and still-vigorous David (1 Chr 29:28) to his unanimously-supported son, Solomon (1 Chr 29:22-24; $2 \mathrm{Chr}$ 1:1), contrasts with the contested succession from a weak David (1 Kgs 1:1-4) to a tentative and naïve Solomon (1 Kgs 1:5-53; 3:7) in the DtrH. Notable Benjaminite omissions from the DtrH include Solomon's avenging of Abner upon Joab (1 Kgs 2:5, 28-34), the avenging of David upon Shimei (2:8-9, 36-46), and the dismissal of Abiathar the priest to his estate in Anathoth for his role in Adonijah's attempted coup (1 Kgs 2:26-27). The Chronicler, in stressing the unanimity of "all Israel" in support of Solomonincluding Benjamin (even Saul's cousin; 27:21b)—conveniently excises reminders of conflict between the houses of Saul and David.

\subsubsection{Summary}

The Chronicler presents an idealized portrait of David and his public administration, and is less concerned with David's personal and family life. A departure from the Deuteronomist's presentation of Benjamin is both a consequence of and a part of this shift in focus vis-à-vis David. By shifting the focus away from David's personal and family life, the Chronicler necessarily omits many of David's dealings with Saul and his household as recorded in 1-2 Samuel. Benjaminites,

${ }^{60}$ Knoppers, 1 Chronicles 10-29, 762.

${ }^{61}$ Knoppers, 1 Chronicles 10-29, 763.

${ }^{62}$ Knoppers, 1 Chronicles 10-29, 763.

${ }^{63}$ Knoppers observes, "It seems that in Chronicles any Israelite contemporary of David who was of any consequence and who ever waged war makes a dedicatory gift" (1 Chronicles 10-29, 886). 
however, are an important part of the idealized "all Israel" from which David draws his support. The result is a more positive_-if less prominent—presentation of Benjamin.

\subsubsection{Reign of Solomon (2 Chr 1-9)}

The Chronicler's account of the reign of Solomon spans nine chapters, and parallels nine chapters in the DtrH (1 Kgs 3-11). The Chronicler subtracts far more than he supplements (1 Kgs 3:16-4:19; 4:22-34 [MT 5:2-14]; 6:4-18, 28-38; 7:1-12, 27-37; 8:55-61; 9:12-16; 10:29-11:40); however, most of these omissions do not contain particularly Benjaminite content.

Perhaps the most important Benjaminite aspect of the Chronicler's account of Solomon's reign is geographical. Solomon's signature achievement (in both Kings and Chronicles) is the construction of the temple in Jerusalem, which is of course part of the Benjamin-Judah border. The Chronicler, consistent with his earlier transformation of 2 Samuel 24 (1 Chr 21:1-22:1), states that the temple site is the threshing floor of Ornan the Jebusite (2 Chr 3:1) — the Deuteronomist does not state the exact location of the temple site.

The Benjaminite aspect of this temple construction is given a slightly different twist in the two works because of the construal of the status of Gibeon. The Deuteronomist is slightly embarrassed by the fact that Solomon sacrifices at Gibeon, applying to Solomon the refrain of mitigated praise found in the book of Kings:

And Solomon loved YHWH, walking in the statutes of his father, David-except (רק) that he sacrificed and burned [incense] on the high places (בבמות). And the king went to Gibeon to sacrifice there (for that was the great high place-a thousand offerings Solomon offered upon that altar). (1 Kgs 3:3-4)

The Chronicler, by contrast, is not at all ashamed of this action-which he transforms from a private pilgrimage into a national assembly (2 Chr 1:2)—since Gibeon was the location of the tent of meeting:

The Solomon and all the assembly with him went to the high place (לבמה) which is in Gibeon, for the tent of meeting (אהל מועד) of Elohim, which Moses the servant of YHWH had made in the wilderness, was there. (2 Chr 1:3)

The Chronicler further enhances the prestige of this high place by reminding the reader that "the bronze altar, which Bezalel the son of Uri, the son of Hur, had made, was there before the sanctuary (משכן) of YHWH" (2 Chr 1:5).

The narratives leave slightly different impressions of this important Benjaminite cultic location. For the Deuteronomist, the ancient Benjaminite cultic location is a "high place," a site of 
dubious status. For the Chronicler, worship at this location was good and right, but belonged to a previous era; once the temple is built, the ark and the tent of meeting are consolidated into the temple (1 Kgs 8:4//2 Chr 5:5), leaving no doubt concerning the "proper" cultic site. After Solomon's encounter with YHWH at Gibeon, he sought YHWH only in Jerusalem (1 Kgs 3:15; 2 Chr 1:13).

One key Benjaminite component omitted from the Vorlage is the prophecy to Jeroboam concerning "ten" tribes taken from Solomon's son, with only “one” tribe left for David's sake (1 Kgs 11:31-32,35). The ambiguous status of Benjamin in this prophecy and in the subsequent narrative of the division of the kingdom (1 Kgs 12) has been discussed previously in this study $(\S 4.1 .2, \S 5.5 .3)$. For the purpose of this section, it will suffice to note that, in the process of "sanitizing" the reign of Solomon through the omission of his apostasy (1 Kgs 11:1-40), the Chronicler has removed the ambiguity of Benjamin's status in the divided kingdom. In 2 Chronicles 10-36, as will be shown, Benjamin's complete loyalty to the kings of Judah is never in doubt, whereas Kings preserves the apparent struggle between the Northern and Jerusalemite kingdoms for Benjaminite territory. ${ }^{64}$

\subsubsection{Kingdom of Judah (2 Chr 10-36)}

The Chronicler's removal of the ambiguity of Benjamin's status begins with the omission of 1 Kings 11 and continues in the re-shaping of the Rehoboam-Jeroboam narratives (1 Kgs 12-14). The Chronicler's adaptation of these three chapters (2 Chr 10-12) results in a shift in perspective on Benjamin in ways that are broadly characteristic of such changes in 2 Chronicles 10-36 as a whole.

The Chronicler emphasizes the parity of Judah and Benjamin during the period of the divided kingdom. Variations of the phrase "Judah and Benjamin" occur eleven times in 2 Chronicles 10-36, ${ }^{65}$ as contrasted with only a single occurrence in Kings (1 Kings 12:23). In the Rehoboam narrative in particular (five occurrences), the Chronicler emphasizes the equality and unity of Judah and Benjamin under the Davidic monarchy. A comparison of three particular verses reveals several relevant changes from the Vorlage:

\footnotetext{
${ }^{64}$ For example, compare the apparently contradictory statements in $1 \mathrm{Kgs}$ 12:20-21 that "the tribe of Judah alone" or "the house of Judah and the tribe of Benjamin" followed the house of David; and, the status of Bethel under Northern control (1 Kgs 12:29, etc.).

65 "The house of Judah and Benjamin" (11:1); "all Israel in Judah and in Benjamin" (11:3); "in Judah and in Benjamin" (11:10); "Judah and Benjamin" (11:12, 23); “all Judah and Benjamin” (15:2, 9; 25:5; 31:1; 34:9); "all the land of Judah and Benjamin" (15:8).
} 
So Israel has been in rebellion against the house of David to this day.

And it happened that when all Israel heard that Jeroboam had returned, they sent and called him to the assembly and made him king over all Israel. None went after the house of David except the tribe of Judah alone.

Then Rehoboam came to Jerusalem and assembled all the house of Judah and the tribe of Benjamin, 180,000 chosen men who made war, to fight against the house of Israel to restore the kingdom to Rehoboam son of Solomon.
So Israel has been in rebellion against the house of David to this day.
Then Rehoboam came to Jerusalem and assembled the house of Judah and Benjamin, 180,000 chosen men who made war, to fight against Israel to restore the kingdom to Rehoboam.

The Chronicler cannot bring himself to call the apostate Northern tribes "all Israel," nor can he state that they made Jeroboam king (וימליכו). He also removes the statement that "Judah alone" followed Rehoboam, which is contradicted by the succeeding verse. Finally, the Chronicler refers to Judah and Benjamin "in the same house," in contrast to 1 Kings 12:21-moreover, "Israel" is not described as "a house."

Next, the Chronicler removes from the Deuteronomistic Rehoboam-Jeroboam section the narratives concerning Jeroboam's reign and his cultic activity at Bethel (1 Kgs 12:29-13:34). Both of these omissions set the pattern for the remainder of Chronicles, which does not consider the Northern kingdom to be legitimate and worthy of inclusion in a (primarily) royal history. The omission of Bethel directs focus away from "illegitimate" Northern worship and the likely historical reality of the Benjamin's divided status.

Finally, the Chronicler supplements the Rehoboam narrative with accounts of the fortification of Jerusalem and Benjamin (2 Chr 11:5, 10, 12, 23); the centralization of the Levites and cultic activities in Jerusalem (11:13-16); and a story of royal and corporate prayer in Jerusalem and YHWH's positive response (12:1-12). These three type scenes recur throughout 2 Chronicles 10-36 during the reigns of Asa, Jehoshaphat, Uzziah, Hezekiah, Manasseh and Josiah, almost exclusively as part of the Sondergut (see Appendix: Table 5). These three types of actions relating to Benjamin (including Jerusalem) are part of the core criteria by which the Chronicler assesses the kings of Judah. 


\subsubsection{Summary}

Benjamin is important in every major section of Chronicles, and in all three sorts of materials relating to those sections (Sondergut, adaptations from the Vorlage, omissions from the Vorlage). Clearly the Chronicler's presentation of Benjamin exhibits a shift from that of the DtrH. In some sections of Chronicles, the shift seems to be part of the Chronicler's primary agenda, while in other sections the shift is incidental to other concerns. The Chronicler highlights the close relationship between Benjamin and Judah—almost certainly exaggerating the connection and oversimplifying historical complexities along the way. The Chronicler believes that his main emphases - the Davidic monarchy, Jerusalem cult, confession and repentance, the unity of "all Israel"- should be embraced equally by Benjaminites as well as Judahites and Levites, whose interests are represented more explicitly in Chronicles.

The following sections will explore the Chronicler's most prominent narrative and thematic omissions from the Vorlage, with the goal of honing an understanding of the Chronicler's "Benjaminite interest."

\subsection{OMISSIONS FROM THE DEUTERONOMISTIC HISTORY ${ }^{66}$}

\subsubsection{Saul and His Household}

This section contrasts the Chronicler's treatment of Saul and his house (or lack thereof) with the Deuteronomist's. The Chronicler's account of David's accession to the throne adroitly reworks the order and emphases of certain events relevant to Saul's offspring.

Most scholars agree that the characterizations of Saul and his family differ in the DtrH and Chronicles. It is clear that the amount of attention paid to Saul and his house by the Chronicler-a genealogy, an account of Saul's death, and mere traces in the accounts of David's reign—represents a shift in focus from that of the DtrH; however, the exact nature of and reasons for that shift is a subject of much debate, as discussed in the fourth chapter of this study (§4.3.2).

The working assumption of this study is that the Saul material in the book of Samuel is a reworked and supplemented version of an originally pro-Saul account that transforms Saul's achievements into failures and sets those failures in contrast with David's strengths ( $\$ 4.3 .1$, $\S 5.4 .2 .3)$. Chronicles represents a slant on Israel's history that is even more solidly pro-David than the Deuteronomistic perspective(s), so it is curious why the Chronicler did not include even more pro-David, anti-Saul material from Samuel. Why not re-edit 1 Samuel to portray David more positively?

${ }^{66}$ The following section incorporates material from my unpublished paper, "Sleeping Dogs: Benjamin-Judah Relations in the Persian Period and the Chronicler's Portrait of Saul." 
Any proposed explanation for the Chronicler's editorial approach to Saul material in his sources must therefore account for the following factors:

- The Chronicler mentions Saul as a "king" (1 Chr 11:2), but includes only an account of his death (10:1-12). Only “a series of flashbacks" ${ }^{\text {"67 }}$ hearken back to Saul's reign (12:1-18; $13: 3){ }^{68}$

- The Chronicler presents a negative evaluation of Saul (10:13-14), but still includes Saul and establishes his pedigree (9:35-44).

- The Chronicler presents a negative evaluation of Saul but includes only an abbreviated list of some of his failures.

- The Chronicler states that David led the people even while Saul was king (11:2), but gives no examples (such as his slaying of Goliath and two hundred other Philistines: 1 Sam 17; 18:27).

- The Chronicler presents all Israel as acknowledging David as king immediately upon Saul's death, including members of Saul's clan $(12: 2,29)$ — but does not mention the support that David received from Michal and Jonathan (1 Sam 18:1-4; 19:1-7, 11-17; 20:1-42; 23:16$18)$.

- The Chronicler typically presents David as positively as possible, but does not include the narratives of his exploits under Saul (1 Sam 17-18), his refusal to kill Saul on two occasions (1 Sam 24, 26), and his covenant-keeping toward Jonathan's son (2 Sam 9).

Knoppers's synthesis provides a compelling explanation of the Chronicler's editorial approach to Saul. The Chronicler sought to strike a delicate balance: "Given the prominence of the tribe of Benjamin in the Chronicler's own day, a prominence the author affirms [in 1 Chronicles 8], Samuel's stories about Benjaminite Saul's demise and Judahite David's rise were likely sensitive issues." ${ }^{69}$ Knoppers argues that the Chronicler considered Saul to be part of the monarchy, but needed to disentangle the stories of Saul and David in order to absolve David of complicity in Saul's demise. ${ }^{70}$ In the Chronicler's view, it must be clear that YHWH and YHWH alone-not David's political maneuvering—made David king.

\footnotetext{
${ }^{67}$ Knoppers, "Israel's First King," 193.

${ }^{68}$ Amit, "Saul Polemic," 651-52.

${ }^{69}$ Knoppers, 1 Chronicles 10-29, 528.

${ }^{70}$ Knoppers, “Israel's First King," 192.
} 
The following section examines specific examples of Saulide omissions from the DtrH in Chronicles, to determine whether Knoppers's proposal also explains the omissions of Saul's household from Chronicles.

\subsubsection{Recollections of Saul and His Reign}

An overtly positive reference to Saul in Chronicles is a passing mention of his war spoils contributing to the treasury for the building of the House of YHWH (1 Chr 26:27-28). Klein astutely contrasts this brief positive allusion to Saul's conquests with Samuel's condemnation of Saul's decision to spare the Amalekites' animals for sacrifice to YHWH (1 Sam 15:9-35). ${ }^{71}$ Here, at least, the Chronicler replaces a negative memory—-Saul, conquest and sacrifice"-with a positive one.

\subsubsection{Jonathan's Love for David}

The Chronicler only mentions Jonathan son of Saul in the genealogies, and in his death (1 Chr 10:2). Given the Chronicler's pro-David stance, his omission of the stories of Jonathan's support for David's succession (especially 1 Sam 18:1-4 and 20:12-17) is surprising-why did he not craft a succession narrative that included the support of Saul's own son (and his daughter, Michal, for that matter)?

The Chronicler evidently felt that the risk of including these stories was too great. Knoppers observes, "Omitting all of the stories of David's relationships with Saul, Jonathan, and the members of Saul's house gives the writer a free hand to dissociate David from Saul." ${ }^{27}$ By prefacing the narrative of Saul's demise with the genealogy of Saul's clan traced to the postexile (9:35-44), the Chronicler exonerates David of any wrongdoing toward the tribe of Benjamin and isolates the cloud of suspicion over Saul and his family, rather than on Benjamin as a whole. ${ }^{73}$ Only Saul's faithfulness to YHWH is tarnished-Benjamin, Jonathan and David go untainted.

\subsubsection{David's Reign: Saul's Household and Relatives}

The Chronicler's story of David's reign draws selectively from the period of his rise to power (2 Sam 2-10) and the appendix of David stories (2 Sam 21-24), while excluding completely

${ }^{71}$ Klein, 1 Chronicles, 495-496.

${ }^{72}$ Knoppers, 1 Chronicles 10-29, 530.

73 "The Chronicler settles the matter of David having any chance to profit personally from his father-in-law's ruin historically by showing that the Jeielite lineage continued well beyond the United Monarchy. In this context, the author can freely acknowledge that the tribe of Benjamin furnished Israel with its first king. The Chronicler can also stress the contributions that the Benjaminites made to the establishment of David's kingdom (1 Chr 11:31; 12:2, 17-19, 30; 27:12, 21). The lineage and tribe of Israel's first monarch are given their due" (Knoppers, 1 Chronicles 10-29, 530). 
the stories of David's failures with Bathsheba and Absalom (2 Sam 11-20). The Chronicler, in pursuing one of his main goals_-portraying David's reign as favorably as possible — conveniently excises nearly all potentially contentious references to Saul's descendants and extended family. Indeed, the Chronicler edits 1 Samuel 31:6-which states that Saul died with his three sons, his armor-bearer, and all his men—to state: "all his house died together" (1 Chr 10:6).

\subsubsection{Ishbosheth/Eshbaal and Abner}

The Chronicler quite prominently omits the war between the houses of Ishbosheth/Eshbaal and David after Saul's death (2 Sam 2-4). The war of succession would certainly be considered one of the low points of Judah-Benjamin relations in the DtrH, so its omission would not be surprising if the Chronicler were concerned about tribal unity.

However, a positive David-Saulide interaction in the DtrH becomes a casualty of the Chronicler's omission of the war of succession. Abner, Saul's uncle, initially installs Ishbosheth as king, but defects to David (2 Sam 3:7-13), makes a covenant with him (כרת ברית; 3:12, 13), and urges "all Israel" to make a covenant with David (3:21).

Chronicles instead replaces the civil war narrative with the account of David's mighty men from the "David appendix" in 2 Samuel (1 Chr 11:10-47//2 Sam 23:8-39), along with an account of large-scale defections to David prior to his accession (1 Chr 12:1-23). This has the effect of pushing the period of tribal conflict back into Saul's reign, rather than extending the conflict into the first seven years of David's formal reign from Hebron (cf 2 Sam 5:5). The Chronicler records David's gathering forces at Hebron (1 Chr 12:24-41), but glosses over any ongoing strife between the two houses following Saul's death (12:30). In the Chronicler's presentation, all Israel was in the process of defecting to David while Saul was alive, but immediately upon Saul's death, all Israel gathered to crown David king (1 Chr 12:38-40). ${ }^{74}$ The "civil war" between Judah- and Benjamin-led factions belongs strictly to Saul's reign.

Eshbaal is only mentioned in the Chronicler's genealogies among Saul's sons—and no offspring are listed (1 Chr 8:33//9:39). The Benjaminite genealogies serve as declarations of Benjamin's important role within larger Israelite identity in the Chronicler's own context. ${ }^{75}$ By this measure, Eshbaal is merely a short horizontal branch in this largely vertical list, since only the line of Jonathan continues.

Eshbaal represented for the Chronicler both a blemish on David's reign and a dark period of hostility between Benjamin and Judah. Omitting Eshbaal from his narrative served the dual purpose of minimizing conflict between the two important tribes and improving David's image. David's

\footnotetext{
${ }^{74}$ Knoppers, "Israel's First King," 188.

${ }^{75}$ Knoppers, 1 Chronicles 1-9, 492.
} 
relationship with Abner could have been viewed suspiciously by a Benjaminite audience: Abner supported David, but his death at the hands of David's general (2 Sam 3:27) - though repudiated by David publically—conveniently removed Saul's uncle as a potential future rival to the throne.

\subsubsection{5 $\mathrm{Michal}^{76}$}

The Chronicler's lone reference to Michal, ${ }^{77}$ daughter of Saul and wife of David, is a single verse in the narrative of the ark's successful journey to Jerusalem (1 Chr 15; 2 Sam 6). In $1 \mathrm{Chr}$ 15:29, Michal looks out the window as the ark approaches the tent which David has set up for it, and she despises David for "leaping and dancing."

The Chronicler omits, however, the later conversation between David and Michal, noted twice in these verses as "Michal the daughter of Saul" (2 Sam 6:20-23). Michal's rebuke and David's humble response are implicitly connected with Michal's barrenness; the narrative concludes: "Michal the daughter of Saul had no child to the day of her death" (2 Sam 6:23).

Japhet notes that the Chronicler makes two changes to the story designed to diffuse criticism of David. In anticipation of Michal's accusation of immodesty, the Chronicler adds "a robe of fine linen" to David's rather sparse ensemble in the 2 Samuel version (2 Sam 6:14//1 Chr 15:27). The Chronicler also omits that David "danced with all his might.," 78 These changes to the story in David's favor are understandable, but it is puzzling that the Chronicler took the trouble to defend David but omitted the argument between Michal and David later in the story.

Perhaps the omission of Michal's rebuke is meant to balance out the necessary omission of previous episodes that would have put her in a positive light. The Chronicler has already chosen to exclude the account of David's rise in Saul's court, so he cannot mention Michal's love for David (1 Sam 18:20) and her assistance in his escape from Saul (1 Sam 19:11-17). Because he cannot include these positive recollections of Michal, he at least softens a negative recollection of her (the ark narrative).

This single mention of Michal is consistent with the Chronicler's pattern of focusing the criticism on the religious failings of Saul's family, away from Benjamin as a tribe. Japhet remarks:

${ }^{76}$ See the discussion in $§ 5.4 .3 .2$ of a possible reference to Michal in $2 \mathrm{Sam}$ 21:8b, which is a text-critical problem. The author's view follows the standard reading of the MT "Michal" as a corruption which should read "Merab," Saul's other daughter.

${ }^{77}$ Knoppers observes that Michal is not listed among David's wives in 1 Chr 3:1-9. This may be because she did not bear David any children (2 Sam 6:23) — but it also has the effect of dissociating the houses of David and Saul. Likewise, Saul's genealogy does not mention his son-in-law, David (Knoppers, “Israel’s First King,” 195).

78 Japhet, I \& II Chronicles, 307. 
Michal's attitude in this matter reflects the traditional position of the house of Saul: a negative stand toward the ark of the Lord (1 Chr 13:3). Even at the very last moment, when the ark arrives in 'the city of David,' the living representative of the house of Saul sticks to this negative, despising attitude - in contrast to David, who does whatever is in his power to "seek God. ${ }^{, 79}$

\subsubsection{Kindness to Mephibosheth}

The Chronicler's omission of the story of David's kindness to Mephibosheth/Merib-baal, Saul's grandson (2 Sam 9; chronologically between $1 \mathrm{Chr} 18$ and 19), is consistent with the complete demise of Saul's house in $1 \mathrm{Chr}$ 10:6 and the omission of the story of David's relationship with Jonathan. The Chronicler's pro-David agenda is trumped here by the importance of avoiding any reminder of Saul's reign and David's role in its downfall.

\subsubsection{Role of Saul's Family in the Absalom Crisis}

2 Samuel 11-20 is perhaps the most damning material concerning David in all of the DtrH. Not only does David commit adultery and murder (2 Sam 11-12), but as his punishment from YHWH he also loses control of his family (2 Sam 13-14) and eventually his kingdom (2 Sam 1520). It is not surprising, then, that the Chronicler would omit this material entirely. The omission of the role of Saul's house in these affairs is a happy byproduct for the Chronicler.

David encounters two members of Saul's family during the Absalom crisis. In his flight from Jerusalem, David is apparently betrayed by Mephibosheth, who allegedly hoped that the house of Israel would "restore the kingdom of his father to him" (2 Sam 16:1-4). David is also harassed by Shimei, "a man of the family of the house of Saul" (2 Sam 16:5), who believes that David's troubles are YHWH's punishment for usurping Saul's kingdom (16:7-8). David's response follows his pattern of humility in all his dealings with Saul's house.

After Absalom's death, David returns to Jerusalem and is met and welcomed by both Shimei and Ziba (2 Sam 19:16-23) and Mephibosheth (2 Sam 19:24-30). Shimei begs forgiveness and Mephibosheth pleads his innocence, and David shows mercy to both. Saul is mentioned twice:

79 Japhet, 1 \& 2 Chronicles, 308. Knoppers comments: "The text should be read in the context of Chronicles, which presents its own distinctive perspective on Saul, his household, and the tribe of Benjamin, from which Saul stems. The fall of Saul results from Saul's own apostasy (10:13-14; 13:3). The transfer of the kingdom to David results from a divine decision $(10: 14 ; 12: 24)$. Recognizing the presence of Yhwh with David, members of Saul's own tribe defect to David (12:1-8, 17). The decision to retrieve the Ark stems from its neglect during the regime of Saul (13:3). Given the Chronicler's recontextualization and recasting of older material, a different perspective emerges from that found in Samuel. In Samuel, Michal has legitimate grounds for complaint. But in Chronicles, which depicts David as properly attired and well-behaved, Michal's contempt is baseless. Her reaction to David, however, is consistent with her father's earlier posture toward the Ark. In Chronicles, Michal's attitude reflects badly on her and the fallen Saulide house she represents" (1 Chronicles 10-29, 626). 
Ziba as "servant of the house of Saul," and Mephibosheth as "son of Saul." Mephibosheth recalls the deadness of his father's household but for David's kindness (19:28).

Interestingly, the Chronicler-in omitting the conflict and bloodshed surrounding Solomon's succession-also excludes David's request that Solomon avenge him on Shimei (1 Kgs 2:8-9), and Solomon's fulfillment of this request (2:36-46).

\subsubsection{Revenge of the Gibeonites}

2 Samuel 21:1-14 is another potentially divisive text omitted by the Chronicler. David allows the Gibeonites to avenge Saul's betrayal of the Josh 9 covenant on seven of Saul's grandsons. The Deuteronomist paints this action in the best possible light: David responds appropriately to YHWH's action and word, and his covenant-keeping with Mephibosheth contrasts nicely with Saul's covenant-breaking. But it is difficult not to view this action-through Benjaminite eyes - as an attempt to destroy potential Saulide challengers to the throne. ${ }^{80}$ Though this story falls outside the "untouchable" tumultuous section of David's reign (2 Sam 11-20), the Chronicler is careful to avoid this story as well.

\subsubsection{Summary}

The Chronicler's reasons for his editorial handling of the Deuteronomist's Saul material were, no doubt, complex and multi-dimensional. We have seen instances in which the Chronicler's apparent goals conflict with one another, and choices were made to adopt, to alter, or to omit source material. In his handling of the Saul material the Chronicler needed to be sensitive to his Benjaminite audience that formed the primary constituency of "all Israel" beside the royal and priestly tribes of Judah and Levi in the Persian period.

The Chronicler adapts a single chapter from Saul's reign from the DtrH—no more, no less. The Chronicler could have included no account of Saul at all—but he would have risked alienating Benjaminites who could convincingly assert Saul's importance as the first king of Israel. The Chronicler could have included more Saul material in order to glorify David and cast aspersion on Saul, but was hesitant to highlight the connections between the families of David and Saul.

This balance also appears to explain the Chronicler's amount of attention to members of Saul's household. He could have excluded them altogether-but did not. He could have included more material, with both positive and negative portrayals of David-but did not. This tension between the pro-David idea and the "all Israel" message applied to Benjamin is an important feature of the Chronicler's editorial approach.

${ }^{80}$ Knoppers, “Israel's First King," 205. 


\subsubsection{Conquest and Judges Period}

Concerning the scope of the Chronicler's work, Japhet writes:

Chronicles describes the history of Israel from beginning to 'beginning', that is, from the inception of human existence with Adam, through the destruction of the first commonwealth during the reign of Zedekiah, to the new commencement with the declaration of Cyrus. It thus constitutes a comprehensive parallel to the earlier historiography from Genesis to Kings... with its conclusion pointing toward a new era. ${ }^{81}$

But if Chronicles is intended to be "comprehensive" in its scope, it is certainly not exhaustive. The Chronicler is clearly aware of the traditions of the patriarchs, the exodus, the wilderness wanderings, the conquest, and the period of the judges - and appears to have used information from the books of Genesis through Judges in some form. Yet he chose to begin his narrative with 1 Samuel 31, choosing to consolidate the narrative contribution of seven-and-a-half books of the Enneateuch into nine chapters of genealogy-why?

Two sorts of explanations can be offered. First, the Chronicler appears to have limited his work to fit on a single scroll of convenient size, of comparable length to Samuel and Kings. ${ }^{82}$ Since it would not have been possible to include the entire history of Adam to Cyrus on such a scroll, the Chronicler had to begin the narrative somewhere-and he happened to choose the death of Saul. But technology alone cannot explain the Chronicler's limited narrative scope. This consideration merely reconstrues the Chronicler's choice as the addition of so much of his own material (e.g., genealogies, $1 \mathrm{Chr} 12 ; 16 ; 22-29$; etc.) at the expense-for example-of narrative summaries of earlier eras. $^{83}$

Therefore, some combination of ideological, theological and historiographical reasons for the Chronicler's limited narrative scope must be sought. It has already been suggested that the puzzling exclusion of Saul's reign but inclusion of his death exhibits concern for a Benjaminite audience. It is worth considering the possibility that a Benjaminite interest is also partly responsible for the Chronicler's replacement of a narrative history rife with tribal conflict with a balanced genealogical survey that presumes, by its grouping of tribes and the persons mentioned, Israel's Joshua- and Judges-era presence in the land (Simeon with Judah, Transjordan tribes, Northern

${ }^{81}$ Japhet, I \& II Chronicles, 8.

${ }^{82}$ Knoppers cites the following totals from personal communication with Dean Forbes: Samuel - 24,302 words; Kings - 25,424 words; Chronicles - 24,058 words. The expansion in spelling when the books were translated into Greek occasioned the division of each of these books into two scrolls (1 Chronicles 1-9, 51).

${ }^{83}$ The Chronicler does not hesitate to summarize at various points-for example, the two-verse summary (1 Chr 10:13-14) of events from 1 Sam 13-28. Elsewhere within Chronicles, radical summarizations of events from Kings include 2 Chr 32:20-27 (2 Kgs 19:1-20:19) and 2 Chr 36:2-21 (2 Kgs 23:31-25:30). 
tribes, etc.). By including a genealogy rather than a narrative summary of Joshua-Judges, the Chronicler is able to bypass all the "difficult" Benjamin material surveyed in the last two chapters: aetiologies of Benjaminite cultic sites; less-than-savory exploits of Benjaminite and Northern judges; and the civil war against Benjamin. The past is acknowledged, but the focus is the integrity of "all Israel" and the connections of the past to the Chronicler's present day.

\subsubsection{Northern Kings and Prophets}

The Chronicler considered the Northern kings illegitimate, and excludes a great deal of material from Kings dealing primarily with Israelite kings and prophets. ${ }^{84}$ It is remarkable that much of the Benjaminite content in 1 Kings 12:25 through 2 Kings 25 is found in sections excluded by the Chronicler. A survey of the Benjaminite references in Chronicles (see Appendix) reveals that most of the Benjaminite content of 2 Chronicles 10-36 is found in the Sondergut. It appears that the Chronicler is replacing one conception of Benjamin with another.

As noted in §5.5.2.2, negative references to Bethel abound in Kings (1 Kgs 12:25-13:34; 2 Kgs 2:23-24; 10:29; 17:28ff; 23:4-20). From the Deuteronomist's perspective, the idolatry of the Northern Kingdom begins and ends at Bethel (1 Kgs 12:29; 2 Kgs 17:28), with echoes of Northern idolatry continuing after Bethel is annexed by Judah (2 Kgs 23:4-20). None of these references is adopted by the Chronicler. Jericho mentioned seven times in three passages (1 Kgs 16:34; $2 \mathrm{Kgs}$ 2:4-18; 25:5), none of which is found in Chronicles. Though the reference to Mizpah (and Geba) in 1 Kings 15:22 are adopted by the Chronicler (2 Chr 16:6), the description of Gedaliah's Mizpahbased government under Babylonian rule is not (2 Kgs 25:23-26).

\subsection{SUMMARY}

Chronicles consistently attempts to portray Benjamin positively from a Judah- and Levicentered perspective. It is difficult to argue that a Benjamin-inclusive agenda is a primary concern of the Chronicler. However, we do find instances in which the Chronicler's editorial decisions become intelligible through the lens of a Benjamin-inclusive agenda-decisions that are difficult to explain in light of the more commonly-understood themes of Chronicles. The attitudes toward Saul

${ }^{84}$ Substantial omissions include narratives of the reign of Jeroboam I (1 Kgs 12:25-14:20); Israelite kings from Nadab through Ahab (15:25-16:34); Elijah (17:1-19:21); Ahab (20:1-21:29); Ahaziah (1 Kgs 22:52-2 Kgs 1:18); Elisha (2 Kgs 2:1-8:15); Jehu (9:1-10:36); Jehoahaz (13:1-9); Elisha’s final prophecy and death (13:14-25); Jeroboam II (14:23-29); Israelite kings from Zechariah through Pekah (15:8-31); and the fall of Israel to Assyria (17:1-41). For a helpful synoptic comparison of these narratives in relation to Chronicles, see Chronicles and Its Synoptic Parallels in Samuel, Kings, and Related Biblical Texts (ed. John C. Endres, William R. Millar, and John Barclay Burns; Collegeville, MN: The Liturgical Press, 1998). 
(in relation to the David theme) and Bethel (in relation to the cult-centralization theme) are particularly stark examples: the brief inclusion of Saul and the excision of Bethel are more fully explained by a pro-Benjamin agenda.

The next chapter will consider in more detail the differences between the literary portraits of Benjamin in the DtrH and Chronicles, and attempt a historical synthesis: situating the Chronicler's modified portrait of Benjamin in the social context of late Persian Yehud. 


\section{PART III}

\section{Chapter 7: The Chronicler's "Benjamin" in Persian Yehud}

Historiography is the art and science of telling accurate, compelling stories about the past. In the three words, "accurate," "compelling," and "stories," one can see Ricoeur's three phases of the historiographical operation: the documentary phase (gathering and sifting of testimonies), the explanatory phase (asking "Why," and "Why does it matter"), and the representative phase (“[offering] a discourse to the readers of history"). ${ }^{1}$ The narrative form, Ricoeur argues, "adds its modes of intelligibility to those of explanation/understanding."2 The narrative is designed to convey meaning and to compel to action.

The present study aims to make a modest contribution to the historiography of the Chronicler's historiography. The Chronicler told and re-told stories of his people's past: gathering and sifting sources, providing explanation, and offering a narrative representation of history from the beginning of the world to the beginning of his own era- a narrative that, he believed, had ongoing implications for his own time and beyond.

As this study has passed through the documentary and (to some extent) the explanatory phases, we now undertake in earnest the task of representation. This final chapter seeks to tell a story: a model that synthesizes literary observations concerning the differences between Chronicles and the DtrH vis-à-vis Benjamin with the existing historical models concerning the Chronicler's setting. The critical tools discussed in the second chapter-identity formation, textual identities, political game theory-will help us construct a model that (hopefully) can successfully connect the literary and historical phenomena, and thus provide a richer understanding of both the book of Chronicles and its context.

${ }^{1}$ Paul Ricoeur, Memory, History, Forgetting (trans. Kathleen Blamey and David Pellauer; Chicago: University of Chicago Press, 2004), 136-37.

${ }^{2}$ Ricoeur, Memory, History, Forgetting, 276. 


\subsection{COMPARISON: BENJAMIN IN THE DEUTERONOMISTIC HISTORY AND CHRONICLES ${ }^{3}$}

After an extensive analysis of the portraits of Benjamin in both the DtrH and Chronicles in the preceding chapters, this section summarizes those portraits and postulates four important points of contrast between the two. The following section will attempt to situate the Chronicler's modified portrait of Benjamin within the socio-political context of Persian Yehud.

\subsubsection{Balanced Portraits of Benjamin: Different Reasons}

The evidence presented in the last two chapters suggests that the DtrH and Chronicles each present a portrait of Benjamin that could be understood as "balanced," but in different ways and for different reasons. The DtrH is a mixture of traditions in which the original pro-Northern and proBenjamin perspectives are evident through the pro-Judah, pro-Levi slant of the final form. Chronicles consists of a more consistent, concerted attempt to portray Benjamin positively from a Judah- and Levi-centered perspective.

Chapter five observed that each of the books of the Former Prophets appears to consist of an edited mix of Northern and Southern traditions (\$5.6). In each instance, the pro-Judah hand seems to be the final layer of editing, but this pro-Judah slant did not obliterate those other traditions, though they have been somewhat obscured and repurposed. For example, the Northern core of Judges is sandwiched between material that highlights Judah as the leading tribe and points toward the need for a Judahite king.

The inclusion of quite a bit of Benjaminite material in the DtrH is primarily due to two factors: the composite nature of the DtrH, which combines traditions from different tribes; and the setting of events it purports to describe. The inclusion of Benjaminite and Northern traditions in the DtrH—even traditions reworked by a pro-Judah editor—gives the books some sort of balance, in that the attention given to the various tribes and tribal coalitions is somewhat evenly distributed. There is "something for everyone," especially Benjaminites, in the DtrH.

By contrast, Chronicles represents a second layer of pro-Judah, pro-Levi editorial activity on the traditions of Israel. This Judah-Levi perspective on each of the tribes and tribal coalitions is more evident and more consistent than in the DtrH, and yet—perhaps surprisingly-Benjamin is

\footnotetext{
${ }^{3}$ The following section incorporates material from my previously unpublished paper, "Sleeping Dogs: Benjamin-Judah Relations in the Persian Period and the Chronicler's Portrait of Saul," presented at the Mid-Atlantic Regional meeting of the Society of Biblical Literature in Baltimore, MD, in March 2013. I am grateful to the conference participants for their constructive feedback.
} 
repeatedly presented positively in each major section of Chronicles. The Chronicler attempts to construct a sort of limited parity between Judah and Benjamin, with Levi in the middle.

\subsubsection{Association of Benjamin with Judah}

Consonant with the generally positive portrait of Benjamin, The Chronicler highlights_ —and probably exaggerates - the historic association of Benjamin with Judah. Throughout the DtrH, Benjamin occupies an ambiguous middle ground between Judah and the Northern tribes—and on a great many occasions, Benjamin appears to be more Northern than Southern. The prophecy concerning Jeroboam's "ten" tribes to Rehoboam's "one" in 1 Kings 11:31-35 is the best example of this ambiguity (cf. §4.1.2, §5.5.3).

The Chronicler removes that ambiguity by associating Benjaminites with David and the Davidic house from the beginning of the narrative of Chronicles. Hints of the division or neutrality of Benjamin in the Rehoboam narrative are removed, in order to "clarify" that Benjamin and Judah together followed the house of David (2 Chr 11:1), along with the Levites and priests (11:13-16). Ten times in the Sondergut the Chronicler uses the phrase, "Judah and Benjamin,"4 highlighting the association between the tribes.

The Chronicler has a strong sense of the importance of "all Israel," which theoretically would include the Northern (and Transjordan) tribes. Chronicles includes these tribes in the genealogical survey of "all Israel," and highlights the support that David received from the other tribes. But Benjamin receives special attention throughout Chronicles as the "first-runner-up" tribe-secondary to Judah and Levi-because Benjamin is the only other self-standing tribe of "all Israel" in the Chronicler's day.

\subsubsection{Cultic Centers}

The Chronicler excludes numerous references to Benjaminite places found in Kings. Bethel is nearly completely excluded, as is Mizpah (§6.2.3). Gibeon is mentioned in Chronicles only until 2 Chronicles 1:13 without reluctance or hesitation as the location of the tabernacle before the building of the temple in Jerusalem.

At least two reasons for these differences between Chronicles and the DtrH could be offered. First, references to Northern cultic activity at these sites could be evidence of the Benjamin's ambiguous or divided political status during the Divided Monarchy, which the

\footnotetext{
${ }^{4}$ Louis C. Jonker, “Of Jebus, Jerusalem and Benjamin: The Chronicler’s Sondergut in 1 Chronicles 21 Against
} the Background of the Late Persian Era in Yehud," in Chronicling the Chronicler: The Book of Chronicles and Early Second Temple Historiography (ed. Tyler F. Williams and Paul S. Evans; Winona Lake, IN: Eisenbrauns, 2013 ), 86-87. 
Chronicler seems to want to avoid (§6.4.3). It is important in Chronicles that Benjamin be associated with Judah early and always.

Perhaps more importantly, references to Bethel and Mizpah in Kings are associated with idolatry and the provisional non-Davidide government under Babylonian rule. There might be several motivations for excluding these episodes, which will be discussed below. But the consequence of the exclusion—and perhaps part of the motivation—was that Benjamin's association with idolatry at these locations is expunged from the Chronicler's account. Benjaminites early and always worshiped in Jerusalem, according to Chronicles.

\subsubsection{Different Conceptions of Monarchy?}

Further explanation for the Chronicler's editorial approach may lie in fundamentally different views of monarchy in Israel. Fleming argues that the "divided" polities of Judah and Israel had different views on royal succession, the roles of elites, and identifiable entities within the polities (called "tribes"). ${ }^{5}$

Fleming observes that the political structures reflected in Israel were more decentralized and tribal-based. Religious and political centers of power were kept separate. Fleming explains the balance of power between individual rulers and the elites who comprised the selectorate:

Individual rulers could be deposed without recourse to the departing royal house, unlike the house of David in Judah. Through the house of Jehu, the first person to be granted kingship in a new royal line was never deposed, according to the biblical portrayal: Saul, David, Jeroboam I, Baasha, Omri, and Jehu. This pattern testifies to the settled nature of the right to rule, once affirmed, even as the treatment of successors indicates the power of other constituents in Israel. The notion of anointing may be linked to this agreement not to depose, and a literary elaboration may be found in the theme of David's refusal to take Saul's life (1 Sam 24, 26). The sons of these founding rulers must then prove themselves, with uneven results: Solomon (of David), Ahab (of Omri), and Jehoahaz (of Jehu) survive evaluation by their constituents, while Eshbaal/Ishbosheth (of Saul), Nadab (of Jeroboam I), and Elah (of Baasha) are all murdered in their second year, evidently a stereotyped term of office for the weak and unworthy. The insecure status of royal successors in Israel suggests a protracted period of struggle between the concentrated power of kings and some kind of collaborative counterbalance, whatever its political basis. Clearly, each new king wished to hand off power to a successor, and no biblical tradition envisions any attempt to thwart the coronation of royal sons. ${ }^{6}$

Judah's political system, on the other hand, was more centralized, characterized by weaker local elites (the "people of the land") and the lack of constituent "tribes" (with "Benjamin as one

${ }^{5}$ Daniel E. Fleming, The Legacy of Israel in Judah's Bible: History, Politics, and the Reinscribing of Tradition (New York: Cambridge University Press, 2012).

${ }^{6}$ Fleming, Legacy of Israel in Judah's Bible, 26-27. 
possible exception" in Jer 17). ${ }^{7}$ Religious and political authorities were centralized in Jerusalem. In contrast to the Israelite tradition, royal heirs were protected from deposition by the overriding principle of filial succession (protected, at least, from rivals outside the royal house).

In terms of selectorate theory (introduced in $\$ 2.3 .1$ and $\$ 3.4 .2 .1$ ), the contrast between the two institutional structures could be characterized as a difference in the size of the winning coalition. In order to establish their rule, Israel's kings needed the support of larger winning coalitions (the tribal elites and generals) than did Judah's kings (perhaps the 'am ha'ares ${ }^{8}$ and the priests). The pool of potential replacement leaders appears to have been wider in Israel than in Judah: no particular tribe was perceived as being more entitled to the throne. Additionally, the potential cost of forming a new winning coalition behind a different leader was apparently lower in Israel, making the replacement of the existing leader more likely. ${ }^{9}$

"Northern” Israel's decentralized, larger-winning-coalition system of "collaborative politics," Fleming argues, was also the political structure of unified, pre-Rehoboam Israel. The decentralized model is found in the books of Judges and Samuel, and continues into the early "monarchy." Saul's son, therefore, was successfully deposed when a winning coalition of Israelite elites shifted their support to David (cf. 2 Sam 3:1, 7-13, 17-21). In this view, Rehoboam's refusal to be deposed and his consolidation of power in a Southern domain are the exception, rather than the rule. ${ }^{10}$

If Fleming is correct that the "collaborative" conception of monarchy was dominant in preand post-Rehoboam Israel, then perhaps this assumption underlies the DtrH's argument concerning monarchy in general and the Davidic monarchy in particular. The DtrH explains (in messy detail) why David did not depose Saul but was chosen to replace Ishbosheth, and why Jeroboam did not depose Solomon but was chosen by Israel to replace Rehoboam (1 Kgs 12:20). ${ }^{11}$ YHWH's

${ }^{7}$ Fleming, Legacy of Israel in Judah's Bible, 25.

${ }^{8}$ Christopher Seitz, Theology in Conflict: Reactions to the Exile in the Book of Jeremiah (Berlin: de Gruyter, 1989), 67. Seitz observes that the 'am ha'ares "actively engaged in dynastic affairs" from time to time, including the overthrow of Athaliah (2 Kgs 11) and Amon (2 Kgs 21:24).

${ }^{9}$ It is important to note that Fleming himself does not use the terms "selectorate" and "winning coalition," but more conventionally refers to "tribal and military elites" and "supporters." The danger of anachronism is always present when attempting to apply modern principles to the study of ancient societies. Nevertheless, the purpose of selectorate theory $(\$ 2.3 .1)$ is to quantify political systems in order to facilitate "apples-to-apples” comparisons of institutional frameworks across time and place.

${ }^{10}$ Fleming, Legacy of Israel in Judah's Bible, 179.

${ }^{11}$ Fleming's theory also partly explains why Sheba's attempted coup (2 Sam 20:1-2)—which is (incorrectly?)

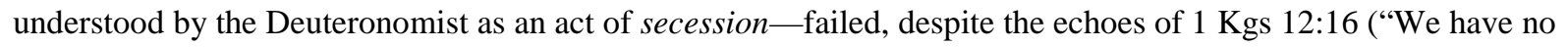
portion in David, Nor do we have inheritance in the son of Jesse; Every man to his tents, O Israel!”). Sheba's movement 
covenant with David (2 Sam 7) establishes an "eternal" royal line, but in the end, both the Northern Kingdom with its series of dynasties and the Southern Kingdom with its single royal bloodline fail to meet the Deuteronomic standard and are exiled for unfaithfulness.

The Chronicler, by contrast, does not appear to accept the collaborative model, preferring a centralized model of both political and religious authority. The Chronicler does not need to demonstrate why Eshbaal lost support to David. Rather, David is chosen of YHWH, and the institutions he established - though interrupted by the exile so that "the land could enjoy its Sabbaths" (2 Chr 36:21; cf. Lev 26:43)—must continue in the Chronicler's own day for "all Israel" (Judah, Benjamin, Levi) to receive YHWH's continued blessing.

\subsubsection{Conclusion}

The Deuteronomistic History and the book of Chronicles present different portraits of Benjamin. Many of the differences and similarities between the portraits of Benjamin closely parallel the general differences between the two presentations of Israel's story-differences in facts, interpretation, theology, and ideology. Certainly the differences between the Deuteronomist's and Chronicler's presentations of Benjamin can be overplayed, but the difference is significant enough to have warranted examination and explanation.

The course of this study thus far has been to establish the tools and parameters by which a difference in the two portraits of Benjamin could be demonstrated as significant and relevant (chapters 2-4), and then to apply those tools to demonstrate a significant difference (chapters 5-6). The task that remains is to suggest how these differences may be relevant to historical reconstruction and biblical interpretation, which will be the focus of the remainder of this chapter.

\subsection{THE CHRONICLER, THE TRIBE OF BENJAMIN, AND PERSIAN YEHUD $^{12}$}

In a recent insightful publication that has previously been referenced, Fleming examines the implications of the curious phenomenon of the use of "Israel" in the Hebrew Bible: the texts that we have are products of a polity that self-identified as "Judah"/“Yehud," but also embraced the term "Israel" to describe its origins (in the Primary History) and its future (throughout the Latter Prophets). ${ }^{13}$ Fleming attempts to disentangle the traditions of Israel (the so-called "Northern

could not gather enough of a winning coalition because it was not proper to depose an anointed king, whereas Rehoboam was still vulnerable to deposition in some sort of probationary period (cf. $1 \mathrm{Kgs} \mathrm{12:3-5).}$

${ }^{12}$ The following section incorporates material from my unpublished paper, "Sleeping Dogs: Benjamin-Judah Relations in the Persian Period and the Chronicler's Portrait of Saul.”

${ }^{13}$ Fleming, Legacy of Israel in Judah's Bible. 
Kingdom") from the Judahite perspective of the Hebrew Bible, taking an approach that is based on polities and self-categorization, rather than on the elusive concept of ethnicity that previous studies have presupposed.

Had the present study been undertaken after the publication of Fleming's work, it could have been given the analogous, elaborate (if clumsy) title, “The legacy of Benjamin in Judah's Former Prophets, and the legacy of and message to Benjamin in Judah's and Levi's book of Chronicles." Benjamin is unique among the tribes that self-identified as descendants of ancient Israel. Benjaminites apparently enjoyed historic ties to Israel, especially the Josephite tribes, but also persisted as a subset of the polity of Judah/Yehud. "Benjaminite" appears to be the most significant non-Judahite, non-Levite self-categorization in the second temple period, as the other tribal identifications of Israel grew less prominent. The presence of Benjamin in Persian-era Hebrew scripture, then, is not only a "legacy," but also a statement about "Israel" to the author's contemporaries.

What were the social contexts of self-identifying "Israelites" in the Chronicler's day? What was the strategy of the Chronicler's message for "Israelites," especially Benjaminites? How successful might that strategy have been?

\subsubsection{Historical Setting}

Assuming a mid-fourth-century date for Chronicles (§3.1.3), and scribal authorship in Jerusalem, the Chronicler (or the community that produced Chronicles) would have been part of the regional capital of a small, rural, relatively insignificant province in the Persian Empire (§3.4.2.2).

It does not seem likely that the Persian government subsidized the Jerusalem cult. Religious and political leaders competed for the taxes on the economic activity (including religious activity) of the landed class of Yehudians, and for the imperial favor brought about by contributing tax revenue to the king's treasury (\$3.4.2.3). Material evidence from this period would suggest that the Jerusalem cult was heavily reliant upon the participation of wealthier areas to its north. Knowles states:

In a situation where most members of the population of Yehud were subsistence farmers living in small unwalled villages, these individual offerings were probably small, so the temple would need the support of a large number of people. ${ }^{14}$

One of the Chronicler's goals may have been expanding the temple's constituency, and thus its revenue and relative prominence. The historically Benjaminite and southern Josephite regions, more

${ }^{14}$ Melody D. Knowles, Centrality Practiced: Jerusalem in the Religious Practice of Yehud \& the Diaspora in the Persian Period (Atlanta: SBL, 2006), 117. 
prosperous than Jerusalem's immediate vicinity, would have been an attractive audience for the Chronicler's message. ${ }^{15}$ Wright suggests:

\begin{abstract}
The small, poor Persian province of Yehud faced new challenges in the demands placed upon them as the land to their immediate south west became the frontier between the land of Egypt and of the Great King. Moreover, ethnoi more numerous, powerful, and wealthier stood to Yehud's southwest, west, northwest, and north. From other sources, we know that the Jerusalem temple struggled to sustain a centralized economic position within the province. A thriving temple economy could help sustain Yehud against the powerful economic and political pressures toward assimilation. ${ }^{16}$
\end{abstract}

The notion of assimilation raises the issue of the self-identification of Yehudians during this period. A previous section discussed at some length the difficulties inherent in various models of community identity (\$2.2.1). That section concluded 1) that no single construct of identityethnicity, nationality, religion-can be used exclusively to describe the self-identifications of Yehudians in this period; 2) that the flexibility of Jewish identity to emphasize different categorizations according to the needs of the community has historically been a reason for the longevity of the "Jewish" categorization; and 3) that a model of identity formation along multiple dimensions (imperial, regional, ethnic, and cultic) best explains the identification(s) of Yehudians in the Persian period (\$2.2.1.3).

The fluidity of identity formation allows us to speculate about the interplay between the biblical texts and the communities that produced them. For example, if a $\mathrm{P}$ community or a Chronistic community sought to reemphasize elements of tradition toward redefinition of religious, ethnic or political identity, there was enough flexibility in the traditions-and perhaps in the communities— to make such an attempt seem feasible (§2.2.2). This flexibility no doubt accounts in part for the survival of the traditions.

The degree to which Yehudian identities in the Chronicler's day were influenced by the legacy of conflict early in the Persian era between the returning golah community and the she'erit is a matter of some debate. Levin argues that, although a golah minority caused some conflict by

\footnotetext{
15 This message appears to be embedded in many of the direct-speech passages in Chronicles. A prime example would be David's appeal in 1 Chr 29. Knoppers writes (in his comments on 1 Chr 26:20-32): "Major benefactors, whose dedications make their way to the treasury, include Samuel the seer, Saul son of Qish, Abner son of Ner, and Joab son of Zeruiah (26:28). It seems that in Chronicles any Israelite contemporary of David who was of any consequence and who ever waged war makes a dedicatory gift. In his speech to the entire assembly (29:1-5), David makes a concerted pitch to enlarge this elite circle of benefactors" (1 Chronicles 10-29, 886).

${ }^{16}$ John W. Wright, "The Priestly Center of the Sons of Levi: Temple Familial Patronage Differentiation in the Book of Chronicles," presented at the annual meeting of the Society of Biblical Literature in Chicago, IL, in November, 2012. I am grateful to Professor Wright for sharing a pre-publication version of this paper with me.
} 
attempting to impose aspects of their exile/Diaspora way of life on the she'erit of Yehud, eventually "the two groups were drawn together." ${ }^{17}$ His scenario identifies the early Persian-era golah-she' erit conflict as a class struggle between the upper-class returnees and "the 'lower,' mostly agrarian stratum of Judahite society." 18 This characterization tells one important part of the story-but does not adequately account for the she'erit elites who opposed the golah reforms. Extrapolating from the geographic extent of the destruction wrought by the Babylonians (§4.1.3-4.1.4), it is reasonable to suggest that the she'erit elites in the Babylonian and Persian province of Yehud were primarily Benjaminite. If it is correct that the golah elites and the agrarian inhabitants of Jerusalem's environs eventually "were drawn together" and had made peace by the Chronicler's time, the displaced she'erit elites may have gravitated toward other centers of religious, political and economic power. The legacy of that conflict may have been mutual hostility or suspicion between Benjaminites and Judahites.

Other cultic centers existed in and around Yehud that competed with Jerusalem for patronage. Outside Yehud, religious centers existed at Elephantine ${ }^{19}$ and possibly in Babylonia at Casiphia. ${ }^{20}$ As noted previously (\$3.4.2.2), it is possible that Benjaminites living between the historically Judahite region and the Josephite region of Samaria would have found religious and economic association with the Samarian province-which was culturally and historically similar to Yehud but more prosperous - to be more advantageous than association with Yehudian institutions like the Jerusalem temple. A Mt. Gerizim temple may have been a powerful competitor to Jerusalem. $^{21}$

The extent of cultic activity at the Benjaminite sites of Gibeon, Bethel and Mizpah in the late Persian period is not known with certainty. Bethel and Gibeon seem to have been active sites during the Babylonian and early Persian periods, ${ }^{22}$ and Mizpah was certainly an administrative

${ }^{17}$ Yigal Levin, “Who Was the Chronicler's Audience? A Hint from His Genealogies,” JBL 122 (2003): 241.

${ }^{18}$ Levin, "Who Was the Chronicler's Audience," 241.

${ }^{19}$ Knowles, Centrality Practiced, 122, 127.

${ }^{20}$ Joseph Blenkinsopp, Ezra-Nehemiah: A Commentary (Old Testament Library; Philadelphia: Westminster Press, 1988), 165-66.

${ }^{21}$ Gary N. Knoppers, "Revisiting the Samarian Question in the Persian Period," in Judah and the Judeans in the Persian Period (ed. Oded Lipschits and Manfred Oeming; Winona Lake, Ind.: Eisenbrauns, 2006), 279; Knowles, Centrality Practiced, 127.

${ }^{22}$ Diana V. Edelman, “Did Saulide-Davidic Rivalry Resurface in Early Persian Yehud?” in The Land That I Will Show You: Essays on the History and Archaeology of the Ancient Near East in Honour of J. Maxwell Miller (ed. J. Andrew Dearman and M. Patrick Graham; Sheffield: Sheffield Academic Press, 2001), 78-81; Joseph Blenkinsopp, "Bethel in the Neo-Babylonian Period," in Judah and the Judeans in the Neo-Babylonian Period (ed. Oded Lipschits and Joseph Blenkinsopp; Winona Lake, IN: Eisenbrauns, 2003), 93-107; idem., "Benjamin Traditions Read in the Early 
center, if not a religious one also (Jer 41:5). The DtrH, as has been shown, contains a diverse set of portrayals of these historic sites - their miraculous origins, and also the shameful failures (from the authors' perspective) that occurred there. Chronicles, by contrast, expunges nearly every reference to Bethel and Mizpah $(\S 6.2 .3, \S 6.4 .3)$. The Chronicler does not overtly exhibit suspicion of Gibeon, as the Deuteronomist does (§6.3.3); Chronicles includes the genealogy of Jeiel, Gibeon’s founder, all the way to the Persian period (1 Chr 8:29-40). But worship at Gibeon belongs to the preJerusalem-temple era (2 Chr 1:13). It seems reasonable to interpret the Chronicler's definitive stance on Bethel (the prominent silence) and Gibeon (over-against the DtrH's mixed portrayal) as evidence of cultic activity at these sites in the Chronicler's day, or at least the legacy of recent activity.

\subsubsection{The Chronicler's Vision}

The Chronicler was probably a Levite of the scribal profession, ${ }^{23}$ working in the administration of a modest temple economy in a backwater town of a less-than-prominent province of the empire. Perpetuating and expanding the influence of his religious, economic and political spheres were important to him. The tools at his disposal were the religious texts and religious symbols of his people, and the historical, economic, religious, and (perceived) ethnic ties to the peoples to the north and northwest, and in the Diaspora.

\subsubsection{Audience}

The Chronicler's work seems to have been directed at a varied audience. As we have seen, some similarities to Greek local histories, as well as a generally positive view of Cyrus and the values of Persian administration, may indicate that the work was intended for broader distribution outside Yehud or Diaspora communities. Nevertheless, the primary focus is Israel's history and the activities of the local Jerusalem cult.

What were the tribal identifications of the Chronicler's audience in and around Yehud? No doubt self-identifying Levites and Judahites were included, but were Benjamin and the Northern tribes intended as well? Some have argued that only Levi, Judah and Benjamin are the Chronicler's

Persian Period," in Judah and the Judeans in the Persian Period (ed. Oded Lipschits and Manfred Oeming; Winona Lake, Ind.: Eisenbrauns, 2006), 643-645.

${ }^{23}$ Louis C. Jonker, "Engaging with Different Contexts: A Survey of the Various Levels of Identity Negotiation in Chronicles," in Texts, Contexts and Readings in Postexilic Literature (ed. Louis C. Jonker; Tübingen: Mohr-Siebeck, 2011), 68 . 
intended audience. ${ }^{24}$ Others hold that the Northern tribes are included as well, in whole ${ }^{25}$ or in part. ${ }^{26}$ The previous chapter suggested-based in part on the fact that 1 Chronicles 9:3 includes Ephraim and Manasseh among the post-exile community but only lists individuals from Judah, Benjamin and Levi (9:4-34)—that the Northern inclusion reflects the Chronicler's "all Israel” ideal, but that a united Levi-Judah-Benjamin would be the primary realistic manifestation of such an ideal in the Chronicler’s day (\$6.3.1). This is not to say that no Yehudians at this time could credibly claim tribal identification other than Levi, Judah and Benjamin. Rather, the contention is that these three are the most significant, substantial, semi-independent identifications at this time. This interpretation helps to explain the Chronicler's conciliatory attitude toward the North, but consistent inclusion of Benjamin — the former is mostly hypothetical, but the latter is real.

\subsubsection{Strategy: Jerusalem Cult}

The Chronicler's rhetorical strategy may be described as irenic and heresthetic. The Chronicler included material in his work that he hoped would mollify the competing factions within his existing political sphere (e.g., the Levitical and priestly groups, ${ }^{27}$ and lay supporters of these

${ }^{24}$ Joel P. Weinberg asserts, "Hieraus folgt, dass 1 Chronik 1-9 eine zweiteilige funktionelle Bestimmung hat: eine engere-die Begrüdung und Bestätigung der Herkunft der Mitglieder der nachexilischen Bürger-TempelGemeinde, ihrer Ansprüche und Rechte, eine weitere-ein Beweis dafür zu sein, dass eben diese von Adam und den Patriarchen abstammende, alle Stämme umfassende, von Juda und Benjamin umrahmte und Levi als Mitte innehabende Gemeinde das Volk Israel ist” (“Das Wesen und funktionelle Bestimmung der Listen in 1 Chr 1-9," ZAW 93 [1981]:

112). See also David Janzen, Witch-Hunts, Purity and Social Boundaries: The Expulsion of the Foreign Women in Ezra 9-10 (JSOTSup 350; London: Sheffield Academic Press, 2002), 101-104.

${ }^{25}$ Japhet (The Ideology of the Book of Chronicles and its Place in Biblical Thought; trans. Anna Barber; Winona Lake, IN: Eisenbrauns, 2009 [first English edition 1997; Hebrew original 1989]) writes: “The Chronicler does not just present the standard system and the abstract idea of the twelve tribes; he goes on to infuse life into the system, portraying it as a functioning ethnic body" (218). See also Jonathan E. Dyck, The Theocratic Ideology of the Chronicler (Biblical Interpretation Series 33; Leiden: Brill, 1999), 119-120.

${ }^{26}$ Levin, "Who Was the Chronicler's Audience,” 242-243. Levin argues, “The genealogies of Judah, Benjamin, Levi, Ephraim, Manasseh, and (southern) Asher are too complex to have come entirely from an old archival source. They display the depth, segmentation, and fluidity that we would associate with oral genealogies in a "living" tribal society....They also contain information that seems to reflect the Chronicler's own day. The logical conclusion would be that these genealogies were adapted from the "living" oral traditions of the people of Judah, Benjamin, Levi, Ephraim, Manasseh, and (southern) Asher in the late Persian period and were intended to reflect the situation of those tribes' clans at the time."

${ }^{27}$ Gary N. Knoppers, "Hierodules, Priests, or Janitors? The Levites in Chronicles and the History of the Israelite Priesthood,” JBL 118 (1999): 71. See also Louis C. Jonker, “David's Officials According to the Chronicler (1 Chronicles 23-27): A Reflection of Second Temple Self-Categorization?” in Historiography and Identity 
groups).Such a move could create a winning coalition comprised of selectorate members within both groups and thereby secure the temple's support base. The Chronicler also sought to change the composition of the selectorate by attracting additional participants in that sphere (especially Benjaminites)_additional participants that he hoped would join his winning coalition. This assertion depends upon the overlap of the religious and political spheres of power, which is ubiquitous in pre-modern societies.

Chapter two of this study ( $\$ 2.3 .3$ in particular) suggested that the Chronicler heresthetically reappropriated and recast the key religious and cultural symbols of his people, especially the Davidic monarchy and the Jerusalem temple. Glatt-Gilad asserts that the recommendation of these symbols was intended "to promote consensus around the institutions, principles and holy writ that formed the defining elements of overall group identity in his time." 28

Knoppers and Jonker have demonstrated this strategy at work relating to the Jerusalem temple, directed internally and externally. ${ }^{29}$ Jonker's interpretation of 1 Chronicles 21 is of particular relevance to Benjamin (see also §6.2.3.1). Jonker argues that by changing the story of 2 Samuel 24 in several important ways and by drawing a contrast between Jerusalem and Gibeon, the Chronicler associates Jerusalem with Benjamin from the very start of cultic activity at that site. ${ }^{30}$ Yet the Chronicler also balances that association by placing the temple on "neutral terrain," preventing Benjamin from appropriating the symbolism of the site completely from Judah:

The Chronicler, a staunch supporter of the Davidic House and the cultic center in Jerusalem, was confronted with the fact that the surrounding Benjaminites had, in the more administratively relaxed Achaemenid dispensation, an opportunity to resuscitate their claim to being the central political and cultic influence. The Chronicler was also confronted with the fact that the Judahite center of political and cultic influence was situated near Benjaminite territory (and could even have been claimed by the Benjaminites). ${ }^{31}$

One of the key aspects of heresthetic strategy is dimensionality, the addition of a new dimension that changes the content or order of questions/decisions, in order to manipulate the outcome (§2.3.3). Three important questions in Chronicles pertaining to the cult are:

(Re)formulation in Second Temple Historiographical Literature (ed. Louis C. Jonker; New York: T\&T Clark, 2010), 65-91; and Wright, "The Priestly Center of the Sons of Levi."

${ }^{28}$ David A. Glatt-Gilad, "Chronicles as Consensus Literature," in What Was Authoritative for Chronicles? (ed. Ehud Ben Zvi and Diana Edelman; Winona Lake, IN: Eisenbrauns, 2011), 75.

${ }^{29}$ Knoppers, "Hierodules, Priests, or Janitors?” and Jonker, “Of Jebus, Jerusalem and Benjamin.”

${ }^{30}$ Jonker, “Of Jebus, Jerusalem and Benjamin,” 93-94.

${ }^{31}$ Jonker, “Of Jebus, Jerusalem and Benjamin,” 95-96. 
1) Who should be part of the worship of YHWH?

2) Where should the cult be located?

3) Which group should oversee the YHWH cult? ${ }^{32}$

If the third question is asked first and the Chronicler provides the answer, "the Aaronides and the Levites, with the support of the Davidide kings," then he risks alienating Benjaminites who might dissociate themselves from "all Israel" (first question) and reject Jerusalem in favor of Benjaminite cultic locations (second question). In 1 Chronicles 21 and following, the Chronicler cleverly answers the questions in the order given above:

1) "All Israel” should worship YHWH, including Benjamin (21:6). Benjamin has "early and always" been an important connection between Judah and "all Israel” (1 Chr 8; 11-12).

2) YHWH should be worshiped in Jerusalem, and Benjamin has always been associated with Jerusalem and its cult (21:18-22:1).

3) Given the first two answers, Levi should administer the cult for the benefit of Benjamin and "all Israel," with the support of the Jerusalemite kings (1 Chr 22-26).

${ }^{32}$ See Scott M. Langston, Cultic Sites in the Tribe of Benjamin: Benjaminite Prominence in the Religion of Israel (New York: Peter Lang Publishing, 1998), 180-200. Langston claims to show that the DtrH reveals a Benjaminite-Levite rivalry for cultic prominence in the period of the judges and the monarchy, as demonstrated by the number of Benjaminite cultic sites (other than Jerusalem), the hostility shown by Benjaminites toward Levites (e.g., Jdg 19; 1 Sam 21-22), and indications of YHWH's hostility toward Benjaminites acting as cultic leaders (e.g., Saul in 1 Sam 13:9; Abinadab's sons in 2 Sam 6:3-8).

However, Langston's work is less than convincing in many respects. He uses Chronicles as evidence that Samuel had Levitical heritage rather than Ephraimite (Cultic Sites, 186-187), and that Joab in fact excluded Benjamin and Levi from the census (1 Chr 21:6; no parallel in 2 Sam 24) because "Benjamin's role in the cult was not forgotten completely" (Cultic Sites, 189)_historical claims that are shaky at best.

Furthermore, Langston overlooks the evidence that Levites enjoyed prominence within Benjamin as cultic leaders-for example, Ahimelech and the Elide priests at Nob (1 Sam 21-22), and Jeremiah of Anathoth (Jer 1:1; 29:27; 32:6-15). Jeremiah is a particularly good example of a Levitical priest serving in Jerusalem with strong ties to Benjamin and pro-Benjamin sympathies (cf. §4.1.3, §4.2.3). A simpler argument would be that Levites were primary cultic leaders (cf. Jdg 17-18), and ministered at various cultic sites throughout Northern, Southern and Benjaminite territories. In any case, Langston's arguments are limited to the judges and monarchic periods and do not necessarily constitute evidence for a Benjamin-Levi rivalry during the Babylonian and Persian periods. It sems more plausible (to this author) that the anti-Benjamin material in the DtrH should be explained in the Babylonian or early Persian periods by a Benjamin-Judah rivalry for political leadership rather than by a Benjamin-Levi rivalry for cultic leadership. It is even more difficult to find evidence of a Benjamin-Levi rivalry for cultic leadership in Chronicles-the tension over cultic leadership seems to be between a Priestly faction and a Levitical faction (cf. Knoppers, "Hierodules, Priests, or Janitors?"). 
The Chronicler thus frames "all Israel" to include Benjamin prominently, which then lends credence to the Jerusalem temple. After commending the Jerusalem cult to Benjaminites, Jonker argues, the Chronicler also protects the cult from cooption by Benjamin.

For the Chronicler, the questions of the proper location, conduct, participation and oversight of the cult are much more than academic or religious. The penitential component of the cult is prominent throughout Chronicles, and the political message is clear: deliverance from enemies of Israel is correlated to royal and corporate confession of $\sin$ in (or toward) the Jerusalem temple. The Chronicler's ability to convince his audience of the credence of his answers to the three questions above-i.e., "all Israel" must worship YHWH in Jerusalem under the oversight of the Levites and Davidides-meant the difference between the success or failure of his people, in his estimation.

\subsubsection{Strategy: Davidic Monarchy}

The previous chapter asserted that the Chronicler attempts to reposition the "Davidic monarchy" symbol as a rallying-point for Judah, Benjamin and "all Israel," rather than as the triumph of a Judahite king over a Benjaminite royal house. This "repositioning" of the Davidic monarchy is an important feature of the Chronicler's outreach to Benjamin, since the Deuteronomistic accounts of David's rise and Saul's downfall could have become a significant obstacle to tribal unity. Knoppers observes that the Deuteronomist's accounts of Saul "would provide Benjaminite readers with plenty of ammunition to claim that their most famous ancestor and his house were treated poorly by Judah's hero.",33

The Chronicler therefore dissociates the two houses and focuses aspersion on Saul himself (rather than on Benjamin as a whole), and highlights instead Benjamin's early and constant support for David (§6.3.2.1).

The Chronicler focuses on David's public "ministries" that had ongoing religious and political significance for the whole community, rather than on David the man, or on David as a king of Judah primarily (with the exception of $1 \mathrm{Chr} 28: 4$ ). The Chronicler's royal ideal is a king who brings peace, is penitent, and supports the temple cult. Saul's career, in the Chronicler's estimation, did not advance the administrative or cultic organization of Israel, and was therefore worthy of no more attention than that given to one of the wicked kings of Judah. Nevertheless, Saul is included as an important link between the judges and the monarchy. According to the Chronicler, the "fact"

${ }^{33}$ Gary N. Knoppers, "Israel's First King and 'the Kingdom of YHWH in the hands of the sons of David': The Place of the Saulide Monarchy in the Chronicler's Historiography," in Saul in Story and Tradition (ed. Carl S. Ehrlich and Marsha C. White; FAT 47; Tübingen: Mohr-Siebeck, 2006), 209. 
that Benjaminites recognized David's election by YHWH and supported him from the beginning redounds to their credit.

Amit is quite critical of the Chronicler's portrait of Saul over-against the Deuteronomist's:

The indictment of Saul in the Book of Chronicles contrasts with the delicate balance of his characterization in the Book of Samuel, where the reader can discern the positive sides of the first chosen king, while at the same time understanding why the kingship was taken from him. In other words, Saul may be criticized while feeling sympathy for him. ${ }^{34}$

Amit is certainly correct that the Chronicler's portrait of Saul is one-sided-but so is the Chronicler's portrait of David. The Deuteronomist's story presents more complex characters, so that David and Saul both receive a more balanced (if not impartial) portrayal. But the Chronicler also excised quite a bit of material that could have made Saul look even worse.

It is perhaps more appropriate to characterize the Chronicler's portrait of Saul and his house as minimalistic, rather than one-sided. This is not "an unambiguously sharpened polemic against the House of Saul," 35 as Amit contends, but rather an adroit avoidance of a piece of contentious history. By cutting out Saul's offspring and key moments of tension between Saul's house and David, the Chronicler attempts to move forward toward an ideal of tribal unity surrounding a purified Jerusalem cult with broad tribal support.

\subsubsection{Strategy: Eschatology}

By "eschatology," we mean the Chronicler's vision of the future of his people in relation to YHWH, their land, and the nations. This aspect of the Chronicler's message is widely debated. ${ }^{36}$ Where does the Chronicler believe that the story of his people is going? Who is part of Israel, and

${ }^{34}$ Yairah Amit, "The Delicate Balance in the Image of Saul and Its Place in the Deuteronomistic History," in Saul in Story and Tradition (ed. Carl S. Ehrlich and Marsha C. White; FAT 47; Tübingen: Mohr-Siebeck, 2006 ), 76.

${ }^{35}$ Yairah Amit, "The Saul Polemic in the Persian Period," in Judah and the Judeans in the Persian Period (ed. Oded Lipschits and Manfred Oeming; Winona Lake, IN: Eisenbrauns, 2006), 656.

${ }^{36}$ Japhet uses the term "eschatology” differently: "[The Chronicler's] expectations are not eschatological, for eschatology is entirely foreign to the Chronicler's way of thinking. They are concrete hopes that the land will be redeemed and Israel's greatness and glory will be restored. The power to realize these hopes rests with the people; they need only follow God's ways and observe His commandments." Restoration involves "gathering the exiles back to the land, settling them in their old territory, and restoring the Davidic monarchy" (Ideology of the Book of Chronicles, 392 , 393).

See also Steven J. Schweitzer, Reading Utopia in Chronicles (LHBOTS 442; London: T\&T Clark, 2007); Ralph W. Klein, 1 Chronicles: A Commentary (Hermeneia series; Minneapolis: Fortress Press, 2006), 48; idem., 2 Chronicles: A Commentary (Hermeneia series; Minneapolis: Fortress Press, 2012), 2-4. 
what is Israel's relationship with the surrounding nations and the ruling empire? How does Benjamin relate to this aspect of the Chronicler's message?

The Chronicler begins with Adam, symbolizing the beginning of humanity, and concludes with Cyrus in mid-sentence, ${ }^{37}$ emphasizing the connection of that point in Israel's story to his own era. In contrast to the DtrH (which seeks to provide a Deuteronomic explanation for the exile), Chronicles understands the fall of Jerusalem, the period of Sabbath rest for the land (2 Chr 36:21), and the restoration under Persian rule as inevitable based on the promises in Deuteronomy 30:1-4 and Leviticus 26:33-45. The continuing story of Israel, for the Chronicler, is the perpetuation of the institutions that were restored under Persian rule according to YHWH's will as a response to Israel's repentance and cultic observance.

Did the Chronicler anticipate the fall of the ruling empire and the reinstatement of the Davidic dynasty? It is difficult to discern the Chronicler's view of Persian rule from the final four verses of Chronicles - the only passage that refers explicitly to Persia-but Cyrus is a positive instrument of YHWH's plan, just as Nebuchadrezzar had been a negative instrument. The Chronicler does retain from 2 Samuel 7 the promise that David's line would continue forever (1 Chr 17:12). Moreover, in Sondergut passages such as 2 Chronicles 12:7-8 and 28:5-15 the Chronicler appears to assert that a state of subjugation by foreign powers is only a temporary chastening from YHWH in order to bring about repentance.

Contrary to ancient Greek accounts, most modern scholars now question the notion that the Persian Empire was in decline in the middle of the fourth century, making it more difficult to argue that the Chronicler hoped to muster Benjaminite support for a rebellion against increasingly weak Persian rule. The Chronicler's goals seem to have been more modest: a degree of autonomy, independence and security for a unified Israel, centered around the Jerusalem cult. If Benjamin, the most substantial "other" tribe in the region, could be rallied to this goal, the Jerusalem cult stood the best chance of success-due both to YHWH's restored favor for unified Israel, and to the increase in economic activity in Jerusalem.

\subsubsection{Summary}

Benjamin is present—-though not always prominent—throughout Chronicles. The Chronicler's goals were complex and multi-layered, as were the texts that he used to form his message. The suggestion that an inclusive rhetorical strategy vis-à-vis Benjamin was a primary goal of the Chronicler could certainly be overstated.

The prominence of Benjamin in the Babylonian and Persian eras, however, demands that the Benjaminite material in Chronicles (and the DtrH) receive greater scrutiny. If Benjamin truly was

\footnotetext{
${ }^{37}$ This suggestion assumes that $2 \mathrm{Chr} 36: 22-23$ is abbreviates Ezra 1:1-3a.
} 
the primary "other" tribal identification in the Chronicler's day, then Benjamin is the most important manifestation of the "all Israel" motif.

\subsubsection{Reception of the Chronicler's Message?}

Inasmuch as this study postulates a conciliatory message to Benjamin in Chronicles, speculation on the reception of that message is a necessary component of the historical hypothesis. If the Chronicler did "reach out" to Benjamin, how might Benjaminites have responded?

First, the fact that Chronicles itself "caught on" as scripture is relevant to this question. The Chronicler's ideological re-presentation of Israel's history was received into the canon of Jewish scripture, meaning that the Chronicler's ideals resonated with at least some of his contemporaries and successors. However, this may be due in large measure to his focus on the Levites, the priests and the cult. If the Chronicler was a Levite and a member of the literati who transmitted the sacred writings and oversaw their ceremonial and instructive use, his work would only have needed the support of his own circle in order to be retained as scripture. (Or, as has been suggested, there was no single "Chronicler," but rather the work is the product of a circle within the literati.)

How might Benjaminites - particularly those outside Jerusalem and on the fringes of the Chronicler's sphere of influence-have received Chronicles? Would that anything like a modern survey or a focus group study had been conducted and preserved for the benefit of modern scholarship! But there are clues in texts from before and after the era in view.

Fleming attempts to situate the origins of Benjaminite tradition found in the DtrH before the early Persian period. Based on references to Benjamin as a "land" within the book of Jeremiahand Benjamin is the only constituent described as such-he suggests:

\footnotetext{
"The land of Benjamin" appears to be accorded a special status within the kingdom of Judah, evidently as preserving a form of identity that did not apply to other territories within the realm.... When the kingdom of Judah was first defeated and then dismantled by the Babylonians at the start of the sixth century, Benjamin's separate identity may have surfaced in a refusal to follow the party of resistance in Judah's last years. ${ }^{38}$
}

Fleming acknowledges Edelman's point that the Deuteronomistic account of the Saul-David rivalry in the early Persian period reflects a Benjamin-Judah rivalry, ${ }^{39}$ but he argues that the preservation of this Saul-David tradition must have older roots in both Benjaminite and Judahite communities in order for the account to resonate with either side:

\footnotetext{
${ }^{38}$ Fleming, Legacy of Israel in Judah's Bible, 160.

${ }^{39}$ Edelman, "Saulide-Davidic Rivalry."
} 
The question then becomes why such a rivalry would have been preserved on either side, not only in Judah but also among the people of Benjamin. Whether or not the conflict between the House of David and the House of Saul originated in actual events when Israel was first ruled by kings, the stories about it must have retained their audiences through the ninth and eighth centuries. ${ }^{40}$

Fleming therefore suggests that Benjamin "maintained a vigorously separate identity throughout the early first millennium, no matter the political dominance of the kingdoms to the north and south."41 If Fleming is correct that the durability of the Saul tradition reflects the endurance of the independent Benjaminite identity, then it is reasonable to argue that such an identity would have continued into the late Persian period-the Chronicler's day. Given the apparent economic disparity between the historically Benjaminite and Judahite regions, a certain degree of independence and mutual wariness seems likely.

Furthermore, it appears that Benjaminite identity as a subset of "Jews" or "Israelites" persisted long after the Chronicler's day. As Davies has pointed out, Saul of Tarsus calls himself an "Israelite" and a "Jew," and proudly claims Benjaminite heritage and the name of the most famous Benjaminite in the Hebrew Bible (see the discussion in $§ 1.1 .1) .{ }^{42}$ Given that Saul's memory was cherished by at least some Benjaminites centuries after Chronicles was written, it may be that Persian-era Benjaminites would have preferred the more detailed Deuteronomistic account of Saul as tragic hero- or perhaps even retained their own positive traditions about Saul that had formed the basis for 1 Samuel 1-14 (see $\$ 4.3 .1, \S 5.4 .2 .2$ ).

The "pro-Benjamin" message in Chronicles that this study suggests may have seemed inclusive to its author and even a Judahite audience. But it is worth wondering whether a Benjaminite audience would have found Benjamin's subordination to the Davidic monarchy and the Levitical cult condescending and unpalatable. Nevertheless, chapter five has argued that there is much within the Chronicler's sources that Benjaminites would also have found objectionable—and yet the DtrH was also retained and revered as scripture by at least some Benjaminites. The Chronicler was limited by the sources he used and their perceived credibility in the communities of his day. Within those limitations, we have suggested that the Chronicler did the best he could have in attempting to bridge the gap between Benjaminites and Judahites/Levites. The argument is not that Chronicles presents an even-handed, unbiased presentation of history, but that the Chronicler's story is more slanted in favor of Benjamin than is the Deuteronomistic History.

\footnotetext{
${ }^{40}$ Fleming, Legacy of Israel in Judah's Bible, 160.

${ }^{41}$ Fleming, Legacy of Israel in Judah's Bible, 160.

${ }^{42}$ Philip R. Davies, “The Trouble With Benjamin," in Reflection and Refraction: Studies in Biblical Historiography in Honour of A. Graeme Auld (ed. R. Rezetko et al.; Leiden: Brill, 2007), 94-96.
} 


\subsection{REVISITING THE HYPOTHESIS}

Having concluded the empirical and synthetic portions of the study, it is now appropriate to revisit the hypothesis of this study and the premises on which it is based. The first chapter proposed the following line of argumentation $(\$ 1.2 .2)$ :

1) The catastrophe of the exile was the catalyst for the composition and formation of much of the Hebrew canon during the Persian period.

2) Persian-era concerns are reflected in the Hebrew canon.

3) The tribes of Judah, Levi and Benjamin were the primary constituent tribes of the people of Yehud during the Persian period, and these distinctions appear to have had continued relevancy in Jewish communities for centuries afterward.

4) The legacy of early Persian-era sectarian conflict between the largely Judahite and Levite golah and the largely Benjaminite she'erit is evident in the Hebrew canon.

5) Two key elements of the Chronicler's agenda are the support of the Jerusalem cult and the definition of "all Israel."

6) The Chronicler's presentation of Benjamin in relation to the royal tribe of JudahBenjamin being the other self-standing tribe besides Judah and Levi in the Persian period-is an important "test case" of the Chronicler's vision of "all Israel" and the Jerusalem cult.

7) The Chronicler respectfully but purposefully appropriates and reshapes canonical material for his contemporary audience (and beyond).

8) A comprehensive comparison between the presentations of Benjamin and its relations with Judah in Chronicles and in the DtrH (the Chronicler's main source) will offer a significant contribution to the understanding of the Chronicler's context, his ideology of "all Israel," and his view of the centrality of the Jerusalem cult.

The hypothesis is expressed in two points $(\S 1.2 .3)$ :

- Chronicles is a unique form of consensus-building literature. The Chronicler's portrayal of Benjamin in relation to Judah reflects an inclusive vision of "all Israel" that walks a fine line: simultaneously valuing Benjamin as an equal partner with Judah (as his "right hand"), yet still protecting the primacy of David as YHWH's chosen ruler, the Levites as the priestly tribe, and Jerusalem as the proper cultic center. 
- Chronicles' portrait of Benjamin differs from that of the DtrH, which portrays Benjamin's relation to Judah as varied and complex. The Chronicler attempts to smooth over these difficulties by highlighting the historically close relationship between the two tribes. In this regard his goals and strategy differ from that of the Deuteronomist, who presents both the high and low points of Judah-Benjamin relations.

The claim that the portraits of Benjamin in the DtrH and Chronicles differ in important ways appears to have been demonstrated in chapters five and six. It also seems quite reasonable to link the Benjaminite content of Chronicles to the "all Israel" theme that is so prominent in the work.

The most questionable aspects of the claims made in this study are those that rest upon current historical reconstructions, especially the fourth and sixth premises. Further archaeological research into the patterns of settlement and destruction in the Babylonian and Persian periods could alter the understanding of sectarian conflicts during this time. How certainly can the conflict in the early Persian period really be characterized as "Benjaminite versus Judahite," and what is the legacy of such conflict in the late Persian period? Where exactly did cultic activity occur (and how much) in and around Yehud that competed with the Jerusalem cult?

The hypothesized "outreach" to Benjamin in Chronicles, though plausible, is also difficult to prove. It has already been suggested that a pro-Benjamin message in Chronicles might have been met with limited acceptance. Given widespread illiteracy, it is difficult to say which texts and traditions various individuals and groups knew of and valued. The Chronicler's pro-Benjamin (from his own perspective) slant might have merely been wishful thinking.

The next chapter summarizes the contributions of this study and suggests avenues for further investigation. 


\section{Chapter 8: Conclusions and Ideas for Further Study}

As an interdisciplinary project that has incorporated elements of historical and literary criticism, social and political theory, and biblical interpretation, this study contributes to the understanding of Jewish history in the Persian period and the book of Chronicles in its historical context. The study begins with the fascinating fact of the prominence of the tribe of Benjamin in the Hebrew Bible, and attempts to situate the prominence of Benjamin in the DtrH and Chronicles within particular historical moments.

This chapter considers the contributions of this study to several currents in biblical scholarship, and suggests several ideas for further study.

\subsection{CONTRIBUTION}

\subsubsection{Exegesis and Biblical Theology}

The overall purpose of this study is to further the understanding of the texts of the Hebrew Bible. The study aids biblical exegesis and biblical theology by explaining various passages and themes within the DtrH and Chronicles that would be difficult to understand apart from the "Benjaminite" aspect. Of particular note are the contrasting portraits of Saul, which have been the object of several previous articles. This study suggests that the differences between the Deuteronomist's and Chronicler's treatment of Saul—as well as other Benjaminite persons and places—reflect different stages in Benjamin-Judah relations in the Persian period.

\subsubsection{The "Benjaminite Substratum" in the Hebrew Bible}

Davies and others have noted the presence of a "Benjaminite substratum" in the Hebrew Bible (\$1.1.1). ${ }^{1}$ But no monograph-length studies of Benjamin have been published since Schunck's in $1963{ }^{2}$ though many articles in the last fifteen years have provided insights into various manifestations of that substratum. Quite a few works have focused on Saul, the most prominent Benjaminite. Fleming's 2012 book on (Northern) Israel pays some attention to Benjamin, and he indicates that a co-authored book (with L. Monroe) focusing on Benjamin is

\footnotetext{
${ }^{1}$ Philip R. Davies, “The Trouble With Benjamin," in Reflection and Refraction: Studies in Biblical Historiography in Honour of A. Graeme Auld (ed. R. Rezetko et al.; Leiden: Brill, 2007), 111.

${ }^{2}$ Klaus-Dietrich Schunck, Benjamin: Untersuchungen zur Entstehung und Geschichte eines israelitischen Stammes (BZAW 86; Berlin: Alfred Töpelmann, 1963).
} 
forthcoming. ${ }^{3}$ Given the consensus around two ideas-that Benjaminite regions fared well under Babylonian and early Persian rule, and that the exilic and postexilic periods produced the canonical texts-Benjamin is increasingly understood as important to historical reconstruction and biblical interpretation.

Though this study has focused on the Benjaminite content of the DtrH and Chronicles, the survey of Benjaminite content in the rest of the Hebrew Bible could serve as a starting point for further study. The significance of Benjamin in the DtrH and Chronicles should prompt investigation into other Benjaminite content in the Bible, even content that does not immediately appear significant for interpretation or historical reconstruction. If nothing else, this study has highlighted the growing mass of scholarly work on the substantial Benjaminite component of the Bible, and attempted to synthesize a modest portion of that body of work.

\subsubsection{The Theologies of the Deuteronomistic History and Chronicles}

This study has attempted to situate the "Benjaminite message" within the Chronicler's main theological program. It is important to stress that the postulated message to Benjamin is not properly a distinct component of the Chronicler's theology, but rather one aspect or manifestation of various components of the Chronicler's theology: "all Israel," Jerusalem cult, and Davidic monarchy. The Benjaminite aspect of these theological components, particularly the "all Israel" component," is a crucial application of the Chronicler's theology in his era and beyond.

This study offers a detailed comparison of a particular theme in the DtrH and Chronicles, and thus contributes to the understanding of the relationship between these two works. Even as some scholars have suggested different models for the literary development of these works (Auld, Ho, and Person), and others propose to reassess the extent of the theological differences between the two works (essays by Ben Zvi, Knoppers, and Jonker), the importance of Benjamin in both works means that the detailed comparison offered is relevant to both discussions. Proponents of the common-source theory would need to account for the differences between the portraits of Benjamin within their models of literary development. If indeed the Deuteronomistic and Chronistic theologies are not as divergent as usually perceived, what accounts for the divergent portraits of Benjamin?

\footnotetext{
${ }^{3}$ Daniel E. Fleming, The Legacy of Israel in Judah's Bible: History, Politics, and the Reinscribing of Tradition
} (New York: Cambridge University Press, 2012), 144n1. In a personal conversation (November 2013), Fleming indicated that this study was still in its early phase. 


\subsubsection{Economic and Political Theories/Categories Applied to Historical Contexts}

This study contributes to the understanding of the social situation in Yehud in the late Persian period, and suggests important differences between that period and the early Persian period, particularly as reflected in the DtrH (among other sources). In particular, we have attempted to apply the tools and concepts of economics, political economy, and social categorization theory to the study of ancient Israel and Yehud. This reflects the recent trend away from problematic concepts of ethnicity and nationalism, toward notions such as identity formation, selfcategorization, and polities.

This study suggests that the historic association of Benjamin with the kingdom of Judah (later, the province of Yehud) over the Josephite tribes is a triumph of economic, political and geographic concerns over perceived closer ethnic ties (§4.1.2).

This study also stresses the importance of understanding cultic practice as economic transaction. ${ }^{4}$ An increase in cultic activity in Jerusalem meant that the priests and Levites enjoyed greater command over the distribution of resources such as meat, wine, oil, and grains. Expanding or decreasing religious influence had highly significant commercial and economic implications for Yehud.

Finally, this study attempts to introduce the related concepts of selectorate theory and heresthetic from the field of political economy into the historical backgrounds of the Hebrew Bible. Selectorate theory - a method of assessing and quantifying the balances of power within institutional frameworks - is used to highlight the differences between the separate polities of Israel and Judah, and to situate the Chronicler and his goals within the overlapping religious, political and economic institutions of late-Persian Yehud. The concept of heresthetic political strategy has been offered as a model for the Chronicler's attempts to balance, co-opt, and persuade the diverse political voices of his context.

\subsection{FURTHER STUDY}

\subsubsection{Benjamin in the Hebrew Bible}

Much work remains to be done concerning the Benjaminite substratum in the Hebrew Bible, particularly regarding the relationship of Benjamin to the Josephite tribes and to Judah. As

\footnotetext{
${ }^{4}$ John W. Wright, "The Priestly Center of the Sons of Levi: Temple Familial Patronage Differentiation in the Book of Chronicles," presented at the annual meeting of the Society of Biblical Literature in Chicago, IL, in November, 2012. Wright points out that sacrifices brought to the temple were partly eaten by the household bringing the offering, but part of the sacrifice was the priests' and Levites' patronage (cf. Lev 6-7; Deut 12:13-27). The implications of this fact (in contrast to a modern notion of wholly-consumed "sacrificial" offering) deserve greater attention in the historical and exegetical literature.
} 
mentioned above, many studies have focused on individual Benjaminite components of books/passages, and more could certainly yield helpful insights. This study has attempted to pursue some of those individual points within the DtrH and Chronicles, and the surveys of Benjaminite content in the books of the DtrH needs to be pursued in further detail.

Davies and Fleming have suggested that large-scale, "big-picture" investigations of Benjamin are in order. For example, intertribal relations between Benjamin and Judah could also be used to inform the understanding of the "collaborationist"/"capitulationist" and "independence" factions in the time of Babylonian invasion and occupation. Jeremiah, Gedaliah, and other Benjaminites support the collaborationist government at Mizpah, but Ishmael and other Judahites sought to repel Babylonian rule. A Benjaminite/“capitulationist”" approach could provide interpretive insights into the book of Jeremiah, for example.

Conversely, an understanding of Israel's tribal history could assist in the dating of various elements of tradition (e.g., certain psalms).

\subsubsection{Persian Yehud, Samaria, and Diaspora}

The insights of this study concerning Chronicles' reflection of the social context of Yehud could be extrapolated to assess the situation of those who historically identified as "Israelites" in the region of Samaria, as well as "Jews"/"Israelites" in the Diaspora. This study has suggested that an outreach to Benjamin is a primary application of the Chronicler's "all Israel" theme; what would be the implications of this fact for Samarians or for those in the Diaspora who maintained ties to Yehud? How do Samarians fit into the Chronicler's worldview/program? Chronicles never describes the fall of Israel to Assyria in detail (cf. 2 Kgs 17), only in passing (2 Chr 30:1-11). Is Chronicles' suggestion of the renewal of historic ties between Judah and the Northern tribes a "good-faith" offer, or symbolic only? How might such a text have been received among selfidentifying "Israelites" in Yehud and Samaria, and how could we know? These lines of questioning could contribute to the understanding of Jewish/Israelite communities in the late Persian and early Hellenistic periods.

\subsubsection{Orality, Textuality, Cult and Education in Yehud}

This study explored some recent works concerning orality and the use of texts in ancient Israelite society, ${ }^{5}$ and postulated that the literary culture in Jerusalem produced a document that

\footnotetext{
${ }^{5}$ For example: Raymond F. Person, The Deuteronomic History and the Book of Chronicles: Scribal Works in
} an Oral World (Atlanta: Society of Biblical Literature, 2010); Karel van der Toorn, Scribal Culture and the Making of the Hebrew Bible (Cambridge: Harvard University Press, 2009); David M. Carr, Writing on the Tablet of the Heart: Origins of Scripture and Literature (New York: Oxford University Press, 2005). 
revised an already-known historiography of Israel, with political aims for that text. But the actual function of that text-and other texts - in the lives of the people of Yehud (and abroad) remains obscure.

To take a related example: if Blenkinsopp, Glatt-Gilad and others are correct that "the Pentateuchal law in its final form represents a compromise between different interest groups with their own legal traditions worked out in several stages during the two centuries of Persian rule,"6 reaching its final form around $400 \mathrm{BCE},{ }^{7}$ how would the competing "interest groups"-who each presumably wanted to hear their own bits of tradition as the Pentateuch was read-have actually enjoyed/engaged/utilized the fruits of that compromise? Was a standardized text read in synagogues (if such things existed), or in public worship at the Jerusalem temple? How widespread was the ability to read written text, and how much of the diverse traditions still existed in the form of memory and oral recitation?

Returning the question of Chronicles, the questions remain: How would the Chronicler's message have been disseminated? How would a text like Chronicles have functioned in the community, practically? More scholarly work is needed to model the interplay between orality and textuality, and the cultic function of written texts.

\subsubsection{Chronicler's Editing}

This study has approached Chronicles as a carefully edited work of theological historiography, with sociopolitical aims. Several of the Chronicles scholars whose observations about Benjamin inspired this study (Jonker, Knoppers, Wright, etc.) have made excellent contributions in this area, and this project could be developed even further. What does the Chronicler have to say about the nations surrounding Israel and the Northern tribes, and how do these groups relate to the Chronicler's immediate context of a primarily Judah-Benjamin-Levi Yehud?

\subsubsection{Common-Source Theory}

Though acknowledging the merits and insights of the "common-source" theories of the development of the DtrH and Chronicles, this study has worked with the assumption that the Chronicler used Samuel and Kings as a source (\$3.2.2.1). It could be suggested that the contrast between the smoother, more positive presentation of Benjamin in Chronicles and the rougher, more

${ }^{6}$ Joseph Blenkinsopp, The Pentateuch: An Introduction to the First Five Books of the Bible (New York: Doubleday, 1992), 241.

${ }^{7}$ David A. Glatt-Gilad, "Chronicles as Consensus Literature," in What Was Authoritative for Chronicles? (ed. Ehud Ben Zvi and Diana Edelman; Winona Lake, IN: Eisenbrauns, 2011), 74. 
patchwork presentation of Benjamin in the DtrH is a valid argument in favor of the view that Chronicles is dependent upon a version of Samuel-Kings that is (mostly) identical to the extant texts. It would be fascinating to consider how the models of parallel textual development (e.g., Person's "Contemporary Competing Historiographies"8) would integrate this study's insights into the literary contrasts between the DtrH's Benjamin and Chronicles' Benjamin. If these historiographies developed "contemporaneously," how did they "compete” over Benjaminite memory?

\title{
8.2.6 Economics, Politics, and Religion
}

Biblical scholarship should always be prepared to appropriate the insights of other disciplines, including history, archaeology, literature, and the social sciences-with due deference and caution. Studies of the interplay between religion, the ancient contexts of the Bible, and the social sciences are not new.

In the last fifty years, however, the discipline of economics has gradually made inroads into many different areas of social scientific research, including the study of the law, history, the family, crime, tastes, irrationality, politics, religion, war, and even the academy itself. One economist claims:

\begin{abstract}
Like the physical sciences, economics uses a methodology that produces refutable implications and tests these implications using solid statistical techniques. In particular, economics stresses three factors that distinguish it from other social sciences. Economists use the construct of rational individuals who engage in maximizing behavior. Economic models adhere strictly to the importance of equilibrium as part of any theory. Finally, a focus on efficiency leads economists to ask questions that other social sciences ignore. These ingredients have allowed economics to invade intellectual territory that was previously deemed to be outside the discipline's realm. ${ }^{9}$
\end{abstract}

Economists have been received into these fields with a mixture of welcome and skepticism, but the impact of the economic approach on these modern academic fields cannot be denied. ${ }^{10}$

\footnotetext{
${ }^{8}$ Raymond F. Person, “The Deuteronomic History and the Books of Chronicles: Contemporary Competing
} Historiographies," in Reflection and Refraction: Studies in Biblical Historiography in Honour of A. Graeme Auld (ed. Robert Rezetko et al.; Leiden: Brill, 2007), 315-336; also, Person, The Deuteronomic History and the Book of Chronicles.

${ }^{9}$ Edward P. Lazear, "Economic Imperialism,” Quarterly Journal of Economics 115(2000): 99.

${ }^{10}$ For example, the pioneering research on crime and the family by Gary Becker, and on irrationality by Daniel Kahneman (a psychologist), both Nobel laureates in economic science. See George J. Stigler, "Economics-The Imperial Science?" Scandinavian Journal of Economics 86(1984): 301-313; Gerard Radnitzky \& Peter Bernholz, eds., Economic Imperialism: The Economic Approach Applied Outside the Field of Economics (New York: Paragon House, 
This study has attempted to integrate insights from the (relatively new) field of political economy. Fleming's work is recent example of the application of economic insights from the fields of sociology and political science to the study of the Hebrew Bible and ancient Israel. Other important historical works on the period usually address the economic aspects of ancient politics and religious practice, but do not explicitly ground their historical insights in the economic way of thinking. This author would like to see biblical historians in the next generation begin to integrate the social-scientific insights produced in each of the traditional fields by the new "economic imperialization"- as the economic insights and methods come into wider acceptance within those fields. 


\section{Appendix: Benjamin References in Chronicles (Supplement to Chapter 6)}

Table 1: "Benjamin”/“Benjaminite” in Chronicles ${ }^{1}$

\begin{tabular}{|c|c|c|}
\hline $\begin{array}{l}\text { English } \\
\text { (MT) }\end{array}$ & NRSV (unless noted) & DtrH Parallel? \\
\hline $1 \mathrm{Chr} 2: 2$ & Dan, Joseph, Benjamin, Naphtali, Gad, and Asher. & Sondergut \\
\hline $\begin{array}{l}6: 60 \\
(6: 45)\end{array}$ & $\begin{array}{l}\text { From the tribe of Benjamin, Geba with its pasture lands, Alemeth } \\
\text { with its pasture lands, and Anathoth with its pasture lands. All their } \\
\text { towns throughout their families were thirteen. }\end{array}$ & Sondergut \\
\hline $\begin{array}{l}6: 65 \\
(6: 50)\end{array}$ & $\begin{array}{l}\text { They also gave them by lot out of the tribes of Judah, Simeon, and } \\
\text { Benjamin these towns that are mentioned by name. }\end{array}$ & Sondergut \\
\hline $7: 6$ & The sons of Benjamin: Bela, Becher, and Jediael, three. & Sondergut \\
\hline $7: 10$ & $\begin{array}{l}\text { The sons of Jediael: Bilhan. And the sons of Bilhan: Jeush, } \\
\text { Benjamin, Ehud, Chenaanah, Zethan, Tarshish, and Ahishahar. }\end{array}$ & Sondergut \\
\hline $8: 1$ & $\begin{array}{l}\text { Benjamin became the father of Bela his firstborn, Ashbel the } \\
\text { second, Aharah the third, }\end{array}$ & Sondergut \\
\hline $8: 40$ & $\begin{array}{l}\text { The sons of Ulam were mighty warriors, archers, having many } \\
\text { children and grandchildren, one hundred fifty. All these were } \\
\text { Benjaminites. }\end{array}$ & Sondergut \\
\hline $9: 3$ & $\begin{array}{l}\text { And some of the people of Judah, Benjamin, Ephraim, and } \\
\text { Manasseh lived in Jerusalem: }\end{array}$ & Sondergut \\
\hline $9: 7$ & $\begin{array}{l}\text { Of the Benjaminites: Sallu son of Meshullam, son of Hodaviah, son } \\
\text { of Hassenuah, }\end{array}$ & Sondergut \\
\hline $11: 31$ & $\begin{array}{l}\text { Ithai son of Ribai of Gibeah of the Benjaminites, Benaiah of } \\
\text { Pirathon, }\end{array}$ & $\begin{array}{c}\text { Vorlage } \\
\text { 2 Sam 23:29 }\end{array}$ \\
\hline $12: 2$ & $\begin{array}{l}\text { They were archers, and could shoot arrows and sling stones with } \\
\text { either the right hand or the left; they were Benjaminites, Saul's } \\
\text { kindred. }\end{array}$ & Sondergut \\
\hline $\begin{array}{l}12: 16 \\
(12: 17)\end{array}$ & Some Benjaminites and Judahites came to the stronghold to David. & Sondergut \\
\hline $\begin{array}{l}12: 29 \\
(12: 30)\end{array}$ & $\begin{array}{l}\text { Of the Benjaminites, the kindred of Saul, three thousand, of whom } \\
\text { the majority had continued to keep their allegiance to the house of } \\
\text { Saul. }\end{array}$ & Sondergut \\
\hline $1 \mathrm{Chr} 21: 6$ & $\begin{array}{l}\text { But he did not include Levi and Benjamin in the numbering, for the } \\
\text { king's command was abhorrent to Joab. }\end{array}$ & Sondergut \\
\hline $27: 12$ & $\begin{array}{l}\text { Ninth, for the ninth month, was Abiezer of Anathoth, a } \\
\text { Benjaminite; in his division were twenty-four thousand. }\end{array}$ & Sondergut \\
\hline $27: 21$ & $\begin{array}{l}\text { for the half-tribe of Manasseh in Gilead, Iddo son of Zechariah; for } \\
\text { Benjamin, Jaasiel son of Abner; }\end{array}$ & Sondergut \\
\hline 2 Chr 11:1 & $\begin{array}{l}\text { When Rehoboam came to Jerusalem, he assembled one hundred } \\
\text { eighty thousand chosen troops of the house of Judah and Benjamin } \\
\text { to fight against Israel, to restore the kingdom to Rehoboam. }\end{array}$ & $\begin{array}{l}\text { Vorlage } \\
1 \text { Kgs } 12: 21\end{array}$ \\
\hline
\end{tabular}

${ }^{1}$ Adapted with elaboration from Louis C. Jonker, “Of Jebus, Jerusalem and Benjamin: The Chronicler's Sondergut in 1 Chronicles 21 Against the Background of the Late Persian Era in Yehud," in Chronicling the Chronicler: The Book of Chronicles and Early Second Temple Historiography (ed. Tyler F. Williams and Paul S. Evans; Winona Lake, IN: Eisenbrauns, 2013), 97-99. 


\begin{tabular}{|c|c|c|}
\hline $11: 3$ & $\begin{array}{l}\text { Say to King Rehoboam of Judah, son of Solomon, and to all Israel in } \\
\text { Judah and Benjamin, }\end{array}$ & $\begin{array}{c}\text { Vorlage } \\
1 \mathrm{Kgs} 12: 23\end{array}$ \\
\hline $11: 10$ & $\begin{array}{l}\text { Zorah, Aijalon, and Hebron, fortified cities that are in Judah and in } \\
\text { Benjamin. }\end{array}$ & Sondergut \\
\hline $11: 12$ & $\begin{array}{l}\text { He also put large shields and spears in all the cities, and made them } \\
\text { very strong. So he held Judah and Benjamin. }\end{array}$ & Sondergut \\
\hline $11: 23$ & $\begin{array}{l}\text { He dealt wisely, and distributed some of his sons through all the } \\
\text { districts of Judah and Benjamin, in all the fortified cities; he gave } \\
\text { them abundant provisions, and found many wives for them. }\end{array}$ & Sondergut \\
\hline $\begin{array}{l}14: 8 \\
(14: 7)\end{array}$ & $\begin{array}{l}\text { Asa had an army of three hundred thousand from Judah, armed with } \\
\text { large shields and spears, and two hundred eighty thousand troops } \\
\text { from Benjamin who carried shields and drew bows; all these were } \\
\text { mighty warriors. }\end{array}$ & Sondergut \\
\hline $15: 2$ & $\begin{array}{l}\text { He went out to meet Asa and said to him, "Hear me, Asa, and all } \\
\text { Judah and Benjamin: The LORD is with you, while you are with } \\
\text { him. If you seek him, he will be found by you, but if you abandon } \\
\text { him, he will abandon you." }\end{array}$ & Sondergut \\
\hline $15: 8$ & $\begin{array}{l}\text { When Asa heard these words, the prophecy of Azariah son of Oded, } \\
\text { he took courage, and put away the abominable idols from all the } \\
\text { land of Judah and Benjamin and from the towns that he had taken in } \\
\text { the hill country of Ephraim. He repaired the altar of the LORD that } \\
\text { was in front of the vestibule of the house of the LORD. }\end{array}$ & Sondergut \\
\hline $15: 9$ & $\begin{array}{l}\text { He gathered all Judah and Benjamin, and those from Ephraim, } \\
\text { Manasseh, and Simeon who were residing as aliens with them, for } \\
\text { great numbers had deserted to him from Israel when they saw that } \\
\text { the LORD his God was with him. }\end{array}$ & Sondergut \\
\hline $17: 17$ & $\begin{array}{l}\text { Of Benjamin: Eliada, a mighty warrior, with two hundred thousand } \\
\text { armed with bow and shield, }\end{array}$ & Sondergut \\
\hline $25: 5$ & $\begin{array}{l}\text { Amaziah assembled the people of Judah, and set them by ancestral } \\
\text { houses under commanders of the thousands and of the hundreds for } \\
\text { all Judah and Benjamin. He mustered those twenty years old and } \\
\text { upward, and found that they were three hundred thousand picked } \\
\text { troops fit for war, able to handle spear and shield. }\end{array}$ & Sondergut \\
\hline $31: 1$ & $\begin{array}{l}\text { Now when all this was finished, all Israel who were present went out } \\
\text { to the cities of Judah and broke down the pillars, hewed down the } \\
\text { sacred poles, and pulled down the high places and the altars } \\
\text { throughout all Judah and Benjamin, and in Ephraim and Manasseh, } \\
\text { until they had destroyed them all. Then all the people of Israel } \\
\text { returned to their cities, all to their individual properties. }\end{array}$ & Sondergut \\
\hline $34: 9$ & $\begin{array}{l}\text { They came to the high priest Hilkiah and delivered the money that } \\
\text { had been brought into the house of God, which the Levites, the } \\
\text { keepers of the threshold, had collected from Manasseh and Ephraim } \\
\text { and from all the remnant of Israel and from all Judah and Benjamin } \\
\text { and from the inhabitants of Jerusalem. }\end{array}$ & Sondergut \\
\hline $34: 32$ & $\begin{array}{l}\text { Then he made all who were present in Jerusalem and in Benjamin } \\
\text { pledge themselves to it. And the inhabitants of Jerusalem acted } \\
\text { according to the covenant of God, the God of their ancestors. }\end{array}$ & Sondergut \\
\hline
\end{tabular}


Table 2: Saul and his relatives in Chronicles $^{2}$

\begin{tabular}{|c|c|c|}
\hline $\begin{array}{c}\text { English } \\
\text { (MT) }\end{array}$ & NRSV (unless noted) & DtrH Parallel? \\
\hline $\begin{array}{l}1 \mathrm{Chr} \\
8: 29-40\end{array}$ & House of Jeiel & Sondergut \\
\hline 9:35-44 & House of Jeiel & Sondergut \\
\hline $10: 2$ & $\begin{array}{l}\text { The Philistines overtook Saul and his sons; and the Philistines killed } \\
\text { Jonathan and Abinadab and Malchishua, sons of Saul. }\end{array}$ & $\begin{array}{l}\text { Vorlage } \\
\text { 1 Sam 31:2 }\end{array}$ \\
\hline $10: 3$ & $\begin{array}{l}\text { The battle pressed hard on Saul; and the archers found him, and he } \\
\text { was wounded by the archers. }\end{array}$ & $\begin{array}{l}\text { Vorlage } \\
1 \text { Sam 31:3 }\end{array}$ \\
\hline $10: 4$ & $\begin{array}{l}\text { Then Saul said to his armor-bearer, "Draw your sword, and thrust } \\
\text { me through with it, so that these uncircumcised may not come and } \\
\text { make sport of me." But his armor-bearer was unwilling, for he was } \\
\text { terrified. So Saul took his own sword and fell on it. }\end{array}$ & $\begin{array}{l}\text { Vorlage } \\
1 \text { Sam } 31: 4\end{array}$ \\
\hline $10: 5$ & $\begin{array}{l}\text { When his armor-bearer saw that Saul was dead, he also fell on his } \\
\text { sword and died. }\end{array}$ & $\begin{array}{c}\text { Vorlage } \\
\text { 1 Sam 31:5 }\end{array}$ \\
\hline 10:6 & $\begin{array}{l}\text { Thus Saul died; he and his three sons and all his house died } \\
\text { together. }\end{array}$ & $\begin{array}{l}\text { Modified Vorlage } \\
1 \text { Sam 31:6 }\end{array}$ \\
\hline $10: 7$ & $\begin{array}{l}\text { When all the men of Israel who were in the valley saw that the army } \\
\text { had fled and that Saul and his sons were dead, they abandoned their } \\
\text { towns and fled; and the Philistines came and occupied them. }\end{array}$ & $\begin{array}{l}\text { Vorlage } \\
\text { 1 Sam 31:7 }\end{array}$ \\
\hline $10: 8$ & $\begin{array}{l}\text { The next day when the Philistines came to strip the dead, they found } \\
\text { Saul and his sons fallen on Mount Gilboa. }\end{array}$ & $\begin{array}{c}\text { Vorlage } \\
1 \text { Sam 31:8 }\end{array}$ \\
\hline 10:11 & $\begin{array}{l}\text { But when all Jabesh-gilead heard everything that the Philistines had } \\
\text { done to Saul, }\end{array}$ & $\begin{array}{c}\text { Vorlage } \\
1 \text { Sam 31:11 }\end{array}$ \\
\hline 10:12 & $\begin{array}{l}\text { all the valiant warriors got up and took away the body of Saul and } \\
\text { the bodies of his sons, and brought them to Jabesh. Then they buried } \\
\text { their bones under the oak in Jabesh, and fasted seven days. }\end{array}$ & $\begin{array}{l}\text { Vorlage } \\
\text { 1 Sam 31:12 }\end{array}$ \\
\hline $10: 13$ & $\begin{array}{l}\text { So Saul died for his unfaithfulness; he was unfaithful to the LORD } \\
\text { in that he did not keep the command of the LORD; moreover, he had } \\
\text { consulted a medium, seeking guidance, }\end{array}$ & Sondergut \\
\hline $11: 2$ & $\begin{array}{l}\text { For some time now, even while Saul was king, it was you who } \\
\text { commanded the army of Israel. The LORD your God said to you: It } \\
\text { is you who shall be shepherd of my people Israel, you who shall be } \\
\text { ruler over my people Israel." }\end{array}$ & $\begin{array}{l}\text { Vorlage } \\
2 \text { Sam 5:2 }\end{array}$ \\
\hline $12: 1$ & $\begin{array}{l}\text { The following are those who came to David at Ziklag, while he } \\
\text { could not move about freely because of Saul son of Kish; they were } \\
\text { among the mighty warriors who helped him in war. }\end{array}$ & Sondergut \\
\hline 12:19 & $\begin{array}{l}\text { Some of the Manassites deserted to David when he came with the } \\
\text { Philistines for the battle against Saul. (Yet he did not help them, for } \\
\text { the rulers of the Philistines took counsel and sent him away, saying, } \\
\text { "He will desert to his master Saul at the cost of our heads.") }\end{array}$ & Sondergut \\
\hline $12: 23$ & $\begin{array}{l}\text { These are the numbers of the divisions of the armed troops who } \\
\text { came to David in Hebron to turn the kingdom of Saul over to him, } \\
\text { according to the word of the LORD. }\end{array}$ & Sondergut \\
\hline $12: 29$ & $\begin{array}{l}\text { Of the Benjaminites, the kindred of Saul, three thousand, of whom } \\
\text { the majority had continued to keep their allegiance to the house of } \\
\text { Saul. }\end{array}$ & Sondergut \\
\hline $13: 3$ & $\begin{array}{l}\text { "Then let us bring again the ark of our God to us; for we did not turn } \\
\text { to it in the days of Saul." }\end{array}$ & Sondergut \\
\hline $15: 29$ & $\begin{array}{l}\text { As the ark of the covenant of the LORD came to the city of David, } \\
\text { Michal daughter of Saul looked out of the window, and saw King } \\
\text { David leaping and dancing; and she despised him in her heart. }\end{array}$ & $\begin{array}{l}\text { Vorlage } \\
\text { 2 Sam 6:16 }\end{array}$ \\
\hline
\end{tabular}

${ }^{2}$ Adapted with elaboration from Jonker, "Of Jebus, Jerusalem and Benjamin," 99-101. 


\begin{tabular}{|l|l|c|}
\hline $17: 13$ & $\begin{array}{l}\text { "I will be his father and he shall be My son; and I will not take My } \\
\text { lovingkindness away from him, as I took it from him who was } \\
\text { before you." }\end{array}$ & $\begin{array}{c}\text { Modified Vorlage } \\
2 \text { Sam 7:15 }\end{array}$ \\
\hline $26: 28$ & $\begin{array}{l}\text { Also all that Samuel the seer, and Saul son of Kish, and Abner son } \\
\text { of Ner, and Joab son of Zeruiah had dedicated-- all dedicated gifts } \\
\text { were in the care of Shelomoth and his brothers. }\end{array}$ & Sondergut \\
\hline $27: 21$ & $\begin{array}{l}\text { for the half-tribe of Manasseh in Gilead, Iddo son of Zechariah; for } \\
\text { Benjamin, Jaasiel son of Abner; }\end{array}$ & Sondergut \\
\hline
\end{tabular}


Table 3: Other (non-Saulide) Benjaminites in the Narrative of Chronicles

\begin{tabular}{|c|c|c|}
\hline $\begin{array}{l}\text { English } \\
\text { (MT) }\end{array}$ & NRSV (unless noted) & DtrH Parallel? \\
\hline $\begin{array}{l}1 \mathrm{Chr} \\
11: 28 \mathrm{~b}\end{array}$ & Abiezer of Anathoth & $\begin{array}{c}\text { Vorlage } \\
2 \text { Sam 23:27a }\end{array}$ \\
\hline $11: 31 \mathrm{a}$ & Ithai son of Ribai of Gibeah of the Benjaminites & $\begin{array}{c}\text { Vorlage } \\
2 \text { Sam 23:29b }\end{array}$ \\
\hline $\begin{array}{l}12: 2-7 \\
(12: 2-8)\end{array}$ & $\begin{array}{l}2 \text { They were archers, and could shoot arrows and sling stones with } \\
\text { either the right hand or the left; they were Benjaminites, Saul's } \\
\text { kindred. } \\
3 \text { The chief was Ahiezer, then Joash, both sons of Shemaah of } \\
\text { Gibeah; also Jeziel and Pelet sons of Azmaveth; Beracah, Jehu of } \\
\text { Anathoth, } \\
4 \text { Ishmaiah of Gibeon, a warrior among the Thirty and a leader over } \\
\text { the Thirty; Jeremiah, Jahaziel, Johanan, Jozabad of Gederah, } \\
5 \text { Eluzai, Jerimoth, Bealiah, Shemariah, Shephatiah the Haruphite; } \\
6 \text { Elkanah, Isshiah, Azarel, Joezer, and Jashobeam, the Korahites; } \\
7 \text { and Joelah and Zebadiah, sons of Jeroham of Gedor. }\end{array}$ & Sondergut \\
\hline $\begin{array}{l}12: 16,18 b \\
(12: 17 \\
19 b)\end{array}$ & $\begin{array}{l}16 \text { Some Benjaminites and Judahites came to the stronghold to } \\
\text { David. } \\
18 \mathrm{~b} \text { Then David received them, and made them officers of his } \\
\text { troops. }\end{array}$ & Sondergut \\
\hline $\begin{array}{l}12: 29 \\
(12: 30)\end{array}$ & $\begin{array}{l}\text { Of the Benjaminites, the kindred of Saul, three thousand, of whom } \\
\text { the majority had continued to keep their allegiance to the house of } \\
\text { Saul. }\end{array}$ & Sondergut \\
\hline $\begin{array}{l}2 \mathrm{Chr} \\
13: 2 \mathrm{~b}\end{array}$ & [Abijah's] mother's name was Micaiah daughter of Uriel of Gibeah. & $\begin{array}{c}\text { Sondergut } \\
1 \mathrm{Kgs} 15: 2 \text { modified }\end{array}$ \\
\hline $\begin{array}{l}14: 8 \\
(14: 7)\end{array}$ & $\begin{array}{l}\text { Asa had an army of three hundred thousand from Judah, armed with } \\
\text { large shields and spears, and two hundred eighty thousand troops } \\
\text { from Benjamin who carried shields and drew bows; all these were } \\
\text { mighty warriors. }\end{array}$ & Sondergut \\
\hline $17: 17-18$ & $\begin{array}{l}17 \text { Of Benjamin: Eliada, a mighty warrior, with two hundred } \\
\text { thousand armed with bow and shield, } \\
18 \text { and next to him Jehozabad with one hundred eighty thousand } \\
\text { armed for war. }\end{array}$ & Sondergut \\
\hline
\end{tabular}


Table 4: Benjaminite Places in Chronicles (other than “Jerusalem") ${ }^{3}$

\begin{tabular}{|c|c|c|}
\hline $\begin{array}{l}\text { English } \\
(\mathrm{MT})\end{array}$ & NRSV (unless noted) & DtrH Parallel? \\
\hline $\begin{array}{l}\text { 1 Chr 6:60 } \\
(6: 45)\end{array}$ & $\begin{array}{l}\text { From the tribe of Benjamin, Geba with its pasture lands, Alemeth } \\
\text { with its pasture lands, and Anathoth with its pasture lands. All their } \\
\text { towns throughout their families were thirteen. }\end{array}$ & Sondergut \\
\hline $\begin{array}{l}1 \text { Chr 6:69 } \\
(6: 54)\end{array}$ & And Aijalon with her suburbs, and Gathrimmon with her suburbs. & Sondergut \\
\hline $7: 28$ & $\begin{array}{l}\text { Their possessions and settlements were Bethel and its towns, and } \\
\text { eastward Naaran, and westward Gezer and its towns, Shechem and } \\
\text { its towns, as far as Ayyah and its towns; }\end{array}$ & Sondergut \\
\hline $8: 6$ & $\begin{array}{l}\text { These are the sons of Ehud (they were heads of ancestral houses of } \\
\text { the inhabitants of Geba, and they were carried into exile to } \\
\text { Manahath): }\end{array}$ & Sondergut \\
\hline $8: 13$ & $\begin{array}{l}\text { And Beriah and Shema (they were heads of ancestral houses of the } \\
\text { inhabitants of Aijalon, who put to flight the inhabitants of Gath) }\end{array}$ & Sondergut \\
\hline $8: 29$ & $\begin{array}{l}\text { Jeiel the father of Gibeon lived in Gibeon, and the name of his wife } \\
\text { was Maacah. }\end{array}$ & Sondergut \\
\hline $9: 35$ & $\begin{array}{l}\text { In Gibeon lived the father of Gibeon, Jeiel, and the name of his wife } \\
\text { was Maacah. }\end{array}$ & Sondergut \\
\hline $11: 4-6$ & $\begin{array}{l}\text { David and all Israel marched to Jerusalem, that is Jebus, where the } \\
\text { Jebusites were, the inhabitants of the land. } \\
5 \text { The inhabitants of Jebus said to David, "You will not come in } \\
\text { here." Nevertheless David took the stronghold of Zion, now the city } \\
\text { of David. } \\
6 \text { David had said, "Whoever attacks the Jebusites first shall be } \\
\text { chief and commander." And Joab son of Zeruiah went up first, so he } \\
\text { became chief. }\end{array}$ & $\begin{array}{l}\text { Vorlage } \\
\text { 2 Sam 5:6-8 }\end{array}$ \\
\hline $11: 28 b$ & Abiezer of Anathoth & $\begin{array}{c}\text { Vorlage } \\
\text { 2 Sam 23:27a }\end{array}$ \\
\hline $11: 31 \mathrm{a}$ & Ithai son of Ribai of Gibeah of the Benjaminites & $\begin{array}{c}\text { Vorlage } \\
\text { 2 Sam 23:29b }\end{array}$ \\
\hline $12: 3$ & $\begin{array}{l}\text { The chief was Ahiezer, then Joash, both sons of Shemaah of } \\
\text { Gibeah; also Jeziel and Pelet sons of Azmaveth; Beracah, Jehu of } \\
\text { Anathoth, }\end{array}$ & Sondergut \\
\hline 12:4 & $\begin{array}{l}\text { Ishmaiah of Gibeon, a warrior among the Thirty and a leader over } \\
\text { the Thirty; Jeremiah, Jahaziel, Johanan, Jozabad of Gederah, }\end{array}$ & Sondergut \\
\hline 14:16 & $\begin{array}{l}\text { David did as God had commanded him, and they struck down the } \\
\text { Philistine army from Gibeon to Gezer. }\end{array}$ & $\begin{array}{l}\text { Modified Vorlage } \\
\text { 2 Sam 5:25 "Geba" }\end{array}$ \\
\hline $16: 39$ & $\begin{array}{l}\text { And he left the priest Zadok and his kindred the priests before the } \\
\text { tabernacle of the LORD in the high place that was at Gibeon, }\end{array}$ & Sondergut \\
\hline $19: 5 b$ & $\begin{array}{l}\text { The king said, "Remain at Jericho until your beards have grown, } \\
\text { and then return." }\end{array}$ & $\begin{array}{c}\text { Vorlage } \\
2 \text { Sam } 10: 5 b\end{array}$ \\
\hline $21: 15-22: 1$ & The threshing floor of Ornan the Jebusite (3x) & $\begin{array}{l}\text { Modified Vorlage } \\
2 \text { Sam 24:16-25 }\end{array}$ \\
\hline $21: 29$ & $\begin{array}{l}\text { For the tabernacle of the LORD, which Moses had made in the } \\
\text { wilderness, and the altar of burnt offering were at that time in the } \\
\text { high place at Gibeon; }\end{array}$ & Sondergut \\
\hline $27: 12$ & $\begin{array}{l}\text { Ninth, for the ninth month, was Abiezer of Anathoth, a } \\
\text { Benjaminite; in his division were twenty-four thousand. }\end{array}$ & Sondergut \\
\hline
\end{tabular}

\footnotetext{
${ }^{3}$ Adapted with elaboration from Jonker, “Of Jebus, Jerusalem and Benjamin,” 101-102.
} 


\begin{tabular}{|c|c|c|}
\hline 2 Chr $1: 3$ & $\begin{array}{l}\text { Then Solomon, and the whole assembly with him, went to the high } \\
\text { place that was at Gibeon; for God's tent of meeting, which Moses } \\
\text { the servant of the LORD had made in the wilderness, was there. }\end{array}$ & $\begin{array}{l}\text { Modified Vorlage } \\
\quad 1 \mathrm{Kgs} 3: 4\end{array}$ \\
\hline $1: 13$ & $\begin{array}{l}\text { So Solomon came from the high place at Gibeon, from the tent of } \\
\text { meeting, to Jerusalem. And he reigned over Israel. }\end{array}$ & Sondergut \\
\hline $3: 1$ & $\begin{array}{l}\text { Solomon began to build the house of the LORD in Jerusalem on } \\
\text { Mount Moriah, where the LORD had appeared to his father David, } \\
\text { at the place that David had designated, on the threshing floor of } \\
\text { Ornan the Jebusite. }\end{array}$ & Sondergut \\
\hline $11: 10$ & $\begin{array}{l}\text { Zorah, Aijalon, and Hebron, fortified cities that are in Judah and in } \\
\text { Benjamin. }\end{array}$ & Sondergut \\
\hline $13: 2$ & $\begin{array}{l}\text { He reigned for three years in Jerusalem. His mother's name was } \\
\text { Micaiah daughter of Uriel of Gibeah. Now there was war between } \\
\text { Abijah and Jeroboam. }\end{array}$ & $\begin{array}{l}\text { Sondergut } \\
1 \mathrm{Kgs} 15: 2 \text { modified }\end{array}$ \\
\hline $13: 4$ & $\begin{array}{l}\text { Then Abijah stood on the slope of Mount Zemaraim that is in the } \\
\text { hill country of Ephraim, and said, "Listen to me, Jeroboam and all } \\
\text { Israel!" }\end{array}$ & Sondergut \\
\hline 13:19 & $\begin{array}{l}\text { Abijah pursued Jeroboam, and took cities from him: Bethel with its } \\
\text { villages and Jeshanah with its villages and Ephron with its villages. }\end{array}$ & Sondergut \\
\hline $16: 1$ & $\begin{array}{l}\text { In the thirty-sixth year of the reign of Asa, King Baasha of Israel } \\
\text { went up against Judah, and built Ramah, to prevent anyone from } \\
\text { going out or coming into the territory of King Asa of Judah. }\end{array}$ & $\begin{array}{l}\text { Vorlage } \\
1 \text { Kgs 15:17 }\end{array}$ \\
\hline $16: 5$ & $\begin{array}{l}\text { When Baasha heard of it, he stopped building Ramah, and let his } \\
\text { work cease. }\end{array}$ & $\begin{array}{c}\text { Vorlage } \\
1 \text { Kgs } 15: 21\end{array}$ \\
\hline $16: 6$ & $\begin{array}{l}\text { Then King Asa brought all Judah, and they carried away the stones } \\
\text { of Ramah and its timber, with which Baasha had been building, and } \\
\text { with them he built up Geba and Mizpah. }\end{array}$ & $\begin{array}{l}\text { Vorlage } \\
1 \text { Kgs 15:22 }\end{array}$ \\
\hline $22: 6$ & $\begin{array}{l}\text { and he returned to be healed in Jezreel of the wounds that he had } \\
\text { received at Ramah, when he fought King Hazael of Aram. And } \\
\text { Ahaziah son of King Jehoram of Judah went down to see Joram son } \\
\text { of Ahab in Jezreel, because he was sick. }\end{array}$ & $\begin{array}{l}\text { Vorlage } \\
2 \text { Kgs 8:29 }\end{array}$ \\
\hline $28: 15$ & $\begin{array}{l}\text { Then those who were mentioned by name got up and took the } \\
\text { captives, and with the booty they clothed all that were naked among } \\
\text { them; they clothed them, gave them sandals, provided them with } \\
\text { food and drink, and anointed them; and carrying all the feeble } \\
\text { among them on donkeys, they brought them to their kindred at } \\
\text { Jericho, the city of palm trees. Then they returned to Samaria. }\end{array}$ & Sondergut \\
\hline $28: 18$ & $\begin{array}{l}\text { And the Philistines had made raids on the cities in the Shephelah and } \\
\text { the Negeb of Judah, and had taken Beth-shemesh, Aijalon, } \\
\text { Gederoth, Soco with its villages, Timnah with its villages, and } \\
\text { Gimzo with its villages; and they settled there. }\end{array}$ & Sondergut \\
\hline
\end{tabular}


Table 5: Benjamin-related Type Scenes in 2 Chronicles 10-36

\begin{tabular}{|c|c|c|c|}
\hline King & $\begin{array}{l}\text { Type Scene: } \\
\text { Fortification of Jerusalem and/or } \\
\text { Benjamin; Cultic and Levitical } \\
\text { centralization in Jerusalem; } \\
\text { Royal/corporate prayer in Jerusalem } \\
\text { and YHWH's positive response }\end{array}$ & English (MT) & DtrH Parallel? \\
\hline \multirow{3}{*}{ Rehoboam } & Fortification of Benjamin & $11: 5,10,12,23$ & Sondergut \\
\hline & Jerusalem centralization & $11: 13-16$ & Sondergut \\
\hline & Prayer in Jerusalem & $12: 1-12$ & $\begin{array}{l}\text { Sondergut expansion } \\
\text { upon Vorlage }\end{array}$ \\
\hline \multirow{3}{*}{ Asa } & Fortification of Benjamin & $14: 6-8(14: 5-7)$ & Sondergut \\
\hline & $\begin{array}{l}\text { Jerusalem centralization of worship-- } \\
\text { Judah, Benjamin, Ephraim, Manasseh, } \\
\text { Simeon }\end{array}$ & $15: 8-10$ & Sondergut \\
\hline & Prayer in Jerusalem, YHWH's response & $15: 12-15$ & Sondergut \\
\hline \multirow{3}{*}{ Jehoshaphat } & $\begin{array}{c}\text { Fortification of Jerusalem with } \\
\text { Benjaminites }\end{array}$ & $17: 13-19$ & Sondergut \\
\hline & $\begin{array}{l}\text { Jerusalem centralization of worship and } \\
\text { Levitical teaching }\end{array}$ & 19:4-11 & Sondergut \\
\hline & Prayer in Jerusalem, YHWH's response & $20: 5-28$ & Sondergut \\
\hline Uzziah & Fortification of Jerusalem & $26: 9,15$ & Sondergut \\
\hline \multirow{5}{*}{ Hezekiah } & $\begin{array}{l}\text { Repair of Jerusalem temple and } \\
\text { rededication of Levites }\end{array}$ & 29 & Sondergut \\
\hline & $\begin{array}{c}\text { Passover celebrated in Jerusalem, } \\
\text { including Benjamin and some Northern } \\
\text { tribes }\end{array}$ & 30 & Sondergut \\
\hline & $\begin{array}{c}\text { Provision for priests and Levites in } \\
\text { Jerusalem }\end{array}$ & 31 & Sondergut \\
\hline & Fortification of Jerusalem & $32: 2-5$ & Sondergut \\
\hline & $\begin{array}{l}\text { Royal prayer in Jerusalem and } \\
\text { YHWH's positive response }\end{array}$ & $32: 20-26$ & $\begin{array}{c}\text { Sondergut } \\
\text { radical summarization } \\
\text { of Vorlage }\end{array}$ \\
\hline \multirow{2}{*}{ Manasseh } & Fortification of Jerusalem & $33: 14$ & Sondergut \\
\hline & Cult centralization in Jerusalem & $33: 15-16$ & Sondergut \\
\hline Josiah & $\begin{array}{l}\text { Cultic reforms in Jerusalem; keeping of } \\
\text { the Passover; cleansing of the Levites }\end{array}$ & $34: 2-35: 19$ & $\begin{array}{c}\text { Vorlage with some } \\
\text { Benjaminite additions }\end{array}$ \\
\hline Cyrus! & Rebuilding of temple in Jerusalem & $36: 22-23$ & Sondergut \\
\hline
\end{tabular}




\section{Bibliography}

Ackroyd, Peter R. "Problems in the Handling of Biblical and Related Sources in the Achaemenid Period." Pages 33-54 in Achaemenid History III: Method and Theory. Edited by Amélie Kuhrt and Heleen Sancisi-Weerdenburg. Leiden: Nederlands Instituut Voor Het Nabije Oosten, 1988.

Albertz, Rainer. Israel in Exile: The History and Literature of the Sixth Century B.C.E. Translated by David Green. Atlanta: Society of Biblical Literature, 2003.

Alexander, Philip S. "Retelling the Old Testament." Pages 99-121 in It Is Written: Scripture Citing Scripture. Essays in Honour of Barnabas Lindars, SSF. Edited by D.A. Carson and H.G.M. Williamson. Cambridge: Cambridge University Press, 1988.

Allen, Leslie C. The Greek Chronicles: The Relation of the Septuagint of I and II Chronicles to the Massoretic Text. 2 vols. VTSup 25, 27. Leiden: Brill, 1974.

Allen, Lindsay. The Persian Empire. Chicago: University of Chicago Press, 2005.

Amit, Yairah. “Araunah's Threshing Floor: A Lesson in Shaping Historical Memory.” Pages 133144 in What Was Authoritative for Chronicles? Edited by Ehud Ben Zvi and Diana Edelman. Winona Lake, IN: Eisenbrauns, 2011.

Amit, Yairah. "The Delicate Balance in the Image of Saul and Its Place in the Deuteronomistic History." Pages 71-79 in Saul in Story and Tradition. Edited by Carl S. Ehrlich and Marsha C. White. FAT 47. Tübingen: Mohr-Siebeck, 2006.

Amit, Yairah. "The Saul Polemic in the Persian Period." Pages 647-661 in Judah and the Judeans in the Persian Period. Edited by Oded Lipschits and Manfred Oeming. Winona Lake, IN: Eisenbrauns, 2006.

Amit, Yairah. "The Story of Ehud (Judges 3:12-30): The Form and the Message." Pages 97-123 in Signs and Wonders: Biblical Texts in Literary Focus. Edited by J. Cheryl Exum. Atlanta: Scholars Press, 1989.

Auld, A. Graeme. Kings without Privilege: David and Moses in the Story of the Bible's Kings. Edinburgh: T. \& T. Clark, 1994.

Auld, A. Graeme. "What Was the Main Source of the Books of Chronicles?" Pages 91-99 in The Chronicler as Author: Studies in Text and Texture. Edited by M. Patrick Graham and Steven L. McKenzie. JSOTSup 263. Sheffield: Sheffield Academic Press, 1999.

Barnes, William H. "Non-Synoptic Chronological References in the Books of Chronicles." Pages 106-131 in The Chronicler as Historian. Edited by M. Patrick Graham, Kenneth G. Hoglund and Steven L. McKenzie. Sheffield: Sheffield Academic Press, 1997. 
Barstad, Hans M. "Deuteronomists, Persians, Greeks, and the Dating of the Israelite Tradition." Pages 47-77 in Did Moses Speak Attic? Jewish Historiography and Scripture in the Hellenistic Period. Edited by Lester L. Grabbe. JSOTSup 317. Sheffield: Sheffield Academic Press, 2001.

Barstad, Hans M. The Myth of the Empty Land: A Study in the History and Archaeology of Judah During the "Exilic” Period. Oslo: Scandinavian University Press, 1996.

Barstad, Hans M. “The Strange Fear of the Bible: Some Reflections on the 'Bibliophobia' in Recent Ancient Israelite Historiography." Pages 120-127 in Leading Captivity Captive: 'The Exile' as History and Ideology. Edited by Lester L. Grabbe. Sheffield: Sheffield Academic Press, 1998.

Barth, Fredrik. "Introduction.” Pages 9-37 in Ethnic Groups and Boundaries: The Social Organization of Culture Difference. Edited by Fredrik Barth. London: Allen \& Unwin, 1969.

Bedford, Peter R. Temple Restoration in Early Achaemenid Judah. JSJSup 65. Leiden: Brill, 2000. Bell, Catherine. Ritual Theory, Ritual Practice. New York: Oxford University Press, 1992.

Bell, Catherine. "Ritualization of Texts and Textualization of Ritual in the Codification of Taoist Liturgy.” History of Religions 27 (1988): 366-392.

Ben Zvi, Ehud. “Are There Any Bridges Out There? How Wide Was the Conceptual Gap Between the Deuteronomistic History and Chronicles?” Pages 59-86 in Community Identity in Judean Historiography: Biblical and Comparative Perspectives. Edited by Gary N. Knoppers and Kenneth A. Ristau. Winona Lake, IN: Eisenbrauns, 2009.

Ben Zvi, Ehud. "The Chronicler as a Historian: Building Texts.” Pages 132-149 in The Chronicler as Historian.

Ben Zvi, Ehud. History, Literature and Theology in the Book of Chronicles._Oakville, Conn.: Equinox, 2006.

Ben Zvi, Ehud. “On Social Memory and Identity Formation in Late Persian Yehud.” Pages 95-148 in Texts, Contexts and Readings in Postexilic Literature. Edited by Louis C. Jonker. Tübingen: Mohr-Siebeck, 2011.

Berger, Peter L. and Thomas Luckmann. The Social Construction of Reality: A Treatise in the Sociology of Knowledge. New York: Anchor Books, 1967 [1966].

Berlin, Adele. “The Exile: Biblical Ideology and Its Postmodern Ideological Interpretation.” Pages 341-356 in Literary Construction of Identity in the Ancient World. Edited by Hanna Liss and Manfred Oeming. Winona Lake, IN: Eisenbrauns, 2010. 
Berquist, Jon L. "Constructions of Identity in Postcolonial Yehud.” Pages 53-66 in Judah and the Judeans in the Persian Period. Edited by Oded Lipschits and Manfred Oeming. Winona Lake, IN: Eisenbrauns, 2006.

Birch, Bruce C. The Rise of the Israelite Monarchy: The Growth and Development of I Samuel 715. SBLDS 27. Missoula, Mont.: Scholars Press, 1976.

Blenkinsopp, Joseph. "Benjamin Traditions Read in the Early Persian Period.” Pages 629-645 in Judah and the Judeans in the Persian Period. Edited by Oded Lipschits and Manfred Oeming. Winona Lake, IN: Eisenbrauns, 2006.

Blenkinsopp, Joseph. "Bethel in the Neo-Babylonian Period." Pages 93-107 in Judah and the Judeans in the Neo-Babylonian Period. Edited by Oded Lipschits and Joseph Blenkinsopp. Winona Lake, IN: Eisenbrauns, 2003.

Blenkinsopp, Joseph. “Did the Second Jerusalemite Temple Possess Land?” Transeuphratène 21 (2001): 61-68.

Blenkinsopp, Joseph. Ezra-Nehemiah: A Commentary. Old Testament Library series. Philadelphia: Westminster Press, 1988.

Blenkinsopp, Joseph. Gibeon and Israel: The Role of Gibeon and the Gibeonites in the Political and Religious History of Early Israel. SOTSMS 2. New York: Cambridge University Press, 1972.

Blenkinsopp, Joseph. "Isaiah.” In The New Oxford Annotated Bible: New Revised Standard Edition with Apocrypha, Augmented Third Edition. Edited by Michael D. Coogan. New York: Oxford University Press, 2007.

Blenkinsopp, Joseph. "The Judaean Priesthood During the Neo-Babylonian and Achaemenid Periods: A Hypothetical Reconstruction." CBQ 60(1998): 25-43.

Blenkinsopp, Joseph. The Pentateuch: An Introduction to the First Five Books of the Bible. New York: Doubleday, 1992.

Blenkinsopp, Joseph. "Temple and Society in Achaemenid Judah.” Pages 22-53 in Second Temple Studies: 1. Persian Period. Edited by Philip R. Davies. JSOTSup 177. Sheffield: Sheffield Academic Press, 1991.

Boling, Robert G. and G. Ernest Wright. Joshua: A New Translation with Notes and Commentary. Anchor Bible Commentary. Garden City, NY: Doubleday, 1982.

Boling, Robert G. Judges: A New Translation with Notes and Commentary. Anchor Bible Commentary. Garden City, NY: Doubleday, 1975.

Borgman, Paul. David, Saul, and God: Rediscovering an Ancient Story. New York: Oxford University Press, 2008. 
Braun, Roddy L. "1 Chronicles 1-9 and the Reconstruction of the History of Israel: Thoughts on the Use of Genealogical Data in Chronicles in the Reconstruction of the History of Israel." Pages 92-105 in The Chronicler as Historian. Edited by M. Patrick Graham, Kenneth G. Hoglund and Steven L. McKenzie. Sheffield: Sheffield Academic Press, 1997.

Breisach, Ernst. Historiography: Ancient, Medieval, and Modern. Chicago: University of Chicago Press, 1983.

Briant, Pierre. From Cyrus to Alexander: A History of the Persian Empire. Translated by Peter T. Daniels. Winona Lake, IN: Eisenbrauns, 2002.

Brooke, George J. "Rewritten Bible.” Pages 777-781 in Encyclopedia of the Dead Sea Scrolls. Edited by Lawrence H. Schiffman and James C. VanderKam. 2 vols. New York: Oxford University Press, 2000.

Bueno de Mesquita, Bruce et al. The Logic of Political Survival. Cambridge, Mass.: MIT Press, 2005 [2003].

Butler, Trent C. Judges. Word Biblical Commentary. Nashville: Thomas Nelson, 2009.

Campbell, Antony F. Of Prophets and Kings: A Late Ninth Century Document (1 Samuel 1 - 2 Kings 10). CBQMS 17. Washington: Catholic Biblical Association of America, 1986.

Carr, David M. The Formation of the Hebrew Bible: A New Reconstruction. New York: Oxford University Press, 2011.

Carr, David M. Writing on the Tablet of the Heart: Origins of Scripture and Literature. New York: Oxford University Press, 2005.

Carroll, Robert P. "Textual Strategies and Ideology in the Second Temple Period.” Pages 108-124 in Second Temple Studies: 1. Persian Period. Edited by Philip R. Davies. JSOTSup 177. Sheffield: Sheffield Academic Press, 1991.

Carter, Charles E. The Emergence of Yehud in the Persian Period: A Social and Demographic Study. JSOTSup 294. Sheffield: Sheffield Academic Press, 1999.

Carter, Charles E. "The Province of Yehud in the Post-Exilic Period: Soundings in Site Distribution and Demography." Pages 106-145 in Second Temple Studies 2. Temple Community in the Persian Period. Edited by Tamara C. Eskenazi and Kent H. Richards. Sheffield: Sheffield Academic, 1994.

Cataldo, Jeremiah W. A Theocratic Yehud? Issues of Government in a Persian Province. New York: T\&T Clark, 2009.

Chisholm, Robert B., Jr. "Ehud: Assessing an Assassin.” Bibliotheca Sacra 168 (2011): 274-282.

Clark, Elizabeth. History, Theory, Text: Historians and the Linguistic Turn. Cambridge, Mass.: Harvard University Press, 2004.

Clifford, Richard J. "Genesis 38: Its Contribution to the Jacob Story.” CBQ 66 (2004): 519-532. 
Coggins, Richard J. The First and Second Books of the Chronicles. Cambridge: Cambridge University Press, 1976.

Coggins, Richard J. "Theology and Hermeneutics in the books of Chronicles." Pages 263-278 in In Search of True Wisdom: Essays in Old Testament Interpretation in Honour of Ronald E. Clements. Edited by Edward Ball. JSOTSup300. Sheffield: Sheffield Academic Press, 1999.

Cohen, Shaye J. D. The Beginnings of Jewishness: Boundaries, Varieties, Uncertainties. Berkeley, CA: University of California Press, 1999.

Creach, Jerome F. D. Joshua. Interpretation Series. Louisville: John Knox, 2003.

Cross, Frank M. "The Themes of the Book of Deuteronomy and the Structure of the Deuteronomistic History." Pages 79-94 in Reconsidering Israel and Judah: Recent Studies on the Deuteronomistic History. Edited by Gary N. Knoppers and J. Gordon McConville. Winona Lake, IN: Eisenbrauns, 2000.

Curtis, Edward L., and Albert A. Madsen. The Books of Chronicles. International Critical Commentary. Edinburgh, 1910.

Davies, Philip R. “Chronicles and the Definition of 'Israel.'” Pages 77-88 in What Was Authoritative for Chronicles? Edited by Ehud Ben Zvi and Diana Edelman. Winona Lake, IN: Eisenbrauns, 2011.

Davies, Philip R. In Search of “Ancient Israel.” Sheffield: JSOT Press, 1992.

Davies, Philip R. “The Origin of Biblical Israel.” Pages 141-148 in Essays on Ancient Israel in Its Near Eastern Context: A Tribute to Nadav Na'aman. Edited by Yairah Amit et al. Winona Lake, IN: Eisenbrauns, 2006.

Davies, Philip R. "Sociology and the Second Temple." Pages 11-21 in Second Temple Studies: 1. Persian Period. Edited by Philip R. Davies. JSOTSup 177. Sheffield: Sheffield Academic Press, 1991.

Davies, Philip R. “Story, Memory, Identity: Benjamin.” Pages 35-45 in Performing Memory in Biblical Narrative and Beyond. Edited by Athalya Brenner and Frank H. Polak. Sheffield: Sheffield Phoenix Press, 2009.

Davies, Philip R. “The Trouble With Benjamin.” Pages 93-111 in Reflection and Refraction:

Studies in Biblical Historiography in Honour of A. Graeme Auld. Edited by R. Rezetko et al. Leiden: Brill, 2007.

Davies, Philip R. and Diana V. Edelman, eds. The Historian and the Bible: Essays in Honour of Lester L. Grabbe. New York: T\&T Clark, 2010.

Dever, William G. Who Were The Early Israelites, And Where Did They Come From? Grand Rapids: Eerdmans, 2003. 
Dobbs-Allsopp, F.W. "R(az/ais)ing Zion in Lamentations 2." Pages 21-68 in David and Zion:

Biblical Studies in Honor of J.J.M. Roberts. Edited by B.F. Batto and K.L. Roberts. Winona Lake, IN: Eisenbrauns, 2004.

Dobbs-Allsopp, F.W. "Rethinking Historical Criticism.” Biblical Interpretation 7(1999): 235-71.

Dobbs-Allsopp, F.W. Weep, O Daughter of Zion: A Study of the City-Lament Genre in the Hebrew Bible. Rome: Editrice Pontifico Istituto Biblico, 1993.

Dörrfuß, Ernst M. Mose in den Chronikbüchern: Garant theokratischer Zukunftserwartung. BZAW 219. Berlin: Walter de Gruyter, 1994.

Dyck, Jonathan E. "The Ideology of Identity in Chronicles." Pages 89-116 in Ethnicity and the Bible. Edited by Mark G. Brett. Biblical Interpretation Series 19. Leiden: Brill, 1996.

Dyck, Jonathan E. The Theocratic Ideology of the Chronicler. Biblical Interpretation Series 33. Leiden: Brill, 1999.

Edelman, Diana V. "Did Saulide-Davidic Rivalry Resurface in Early Persian Yehud?” Pages 69-91 in The Land That I Will Show You: Essays on the History and Archaeology of the Ancient Near East in Honour of J. Maxwell Miller. Edited by J. Andrew Dearman and M. Patrick Graham. Sheffield: Sheffield Academic Press, 2001.

Edelman, Diana V. "Ethnicity and Early Israel." Pages 25-55 in Ethnicity and the Bible. Edited by Mark G. Brett. Biblical Interpretation Series 19. Leiden: Brill, 1996.

Edelman, Diana V. King Saul and the Historiography of Judah. JSOTSup 121. Sheffield: Sheffield Academic Press, 1991.

Edelman, Diana V. "Saul." Page 993 in Anchor Bible Dictionary, vol. 5. Edited by David Noel Freedman. New York: Doubleday Publishing, 1992.

Edelman, Diana V. and Lynette Mitchell. "Chronicles and Local Greek Histories." Pages 229-252 in What Was Authoritative for Chronicles? Edited by Ehud Ben Zvi and Diana Edelman. Winona Lake, IN: Eisenbrauns, 2011.

Endres, John C., William R. Millar, and John Barclay Burns, eds. Chronicles and Its Synoptic Parallels in Samuel, Kings, and Related Biblical Texts. Collegeville, Minn.: The Liturgical Press, 1998.

Entine, Jon. Abraham's Children: Race, Identity and the DNA of the Chosen People. New York: Grand Central Publishing, 2007.

Faust, Avraham. "Settlement Patterns and State Formation in Southern Samaria and the Archaeology of (a) Saul." Pages 14-38 in Saul in Story and Tradition. Edited by Carl S. Ehrlich and Marsha C. White. FAT 47. Tübingen: Mohr-Siebeck, 2006.

Fin, Ben and Dimitris Milonakis. From Economics Imperialism to Freakonomics: The Shifting Boundaries Between Economics and Other Social Sciences. New York: Routledge, 2009. 
Finkelstein, Israel. "The Emergence of the Monarchy in Israel: The Environmental and Socioeconomic Aspects." JSOT 44(1989): 43-74.

Finkelstein, Israel. "The Historical Reality Behind the Genealogical Lists in 1 Chronicles." JBL 131 (2012): 65-83.

Finkelstein, Israel and Amihai Mazar. The Quest For the Historical Israel: Debating Archaeology and the History of Early Israel. Edited by Brian B. Schmidt. Atlanta: Society of Biblical Literature, 2007.

Finkelstein, Israel and Lily Singer-Avitz. "Reevaluating Bethel.” Zeitschrift des Deutschen Palästina-Vereins 125 (2009): 33-48.

Finkelstein, Israel and Neil Asher Silberman. The Bible Unearthed: Archaeology's New Vision of Ancient Israel and the Origin of Its Sacred Texts. New York: Free Press, 2001.

Fishbane, Michael. Biblical Interpretation in Ancient Israel. New York: Oxford University Press, 1986.

Fleming, Daniel E. The Legacy of Israel in Judah's Bible: History, Politics, and the Reinscribing of Tradition. New York: Cambridge University Press, 2012.

Fried, Lisbeth S. "The 'am hā'āreș in Ezra 4:4 and the Persian Imperial Administration." Pages 123-145 in Judah and the Judeans in the Persian Period. Edited by Oded Lipschits and Manfred Oeming. Winona Lake, IN: Eisenbrauns, 2006.

Gerstenberger, Erhard S. Israel in the Persian Period: The Fifth and Fourth Centuries B.C.E. Translated by Siegfried S. Schatzmann. Atlanta: SBL, 2011 (2005).

Giffone, Benjamin D. "From Time-Bound to Timeless: The Rhetoric of Lamentations and Its Appropriation.” MTh thesis, Stellenbosch University. < http://hdl.handle.net/10019.1/20205> (2012).

Giffone, Benjamin D. "Sleeping Dogs: Benjamin-Judah Relations in the Persian Period and the Chronicler's Portrait of Saul." Paper for the Mid-Atlantic Regional meeting of the Society of Biblical Literature (Baltimore, MD: March 15, 2013).

Giffone, Benjamin D. “The Timeless, Unifying Rhetoric of Lamentations.” OTE 25 (2012): 534558.

Glatt-Gilad, David A. "Chronicles as Consensus Literature.” Pages 67-75 in What Was Authoritative for Chronicles? Edited by Ehud Ben Zvi and Diana Edelman. Winona Lake, IN: Eisenbrauns, 2011.

Grabbe, Lester L. Ancient Israel: What Do We Know and How Do We Know It? London: T\&T Clark, 2007. 
Grabbe, Lester L. “"The Exile’ Under the Theodolite: Historiography as Triangulation.” Pages 80100 in Leading Captivity Captive: 'The Exile' as History and Ideology. Edited by Lester L. Grabbe. Sheffield: Sheffield Academic Press, 1998.

Grabbe, Lester L. Ezra-Nehemiah. Old Testament Readings. New York: Routledge, 1998.

Grabbe, Lester L. A History of the Jews and Judaism in the Second Temple Period, Volume 1:

Yehud: A History of the Persian Province of Judah. London: T\&T Clark, 2004.

Grabbe, Lester L. A History of the Jews and Judaism in the Second Temple Period, Volume 2: The Coming of the Greeks: The Early Hellenistic Period (335-175 BCE). London: T\&T Clark, 2008.

Grabbe, Lester L. "Jewish Historiography and Scripture in the Hellenistic Period." Pages 129-155 in Did Moses Speak Attic? Jewish Historiography and Scripture in the Hellenistic Period. Edited by Lester L. Grabbe. Sheffield: Sheffield Academic Press, 2001.

Grabbe, Lester L. "Who Were the First Real Historians? On the Origins of Critical Historiography." Pages 156-181 in Did Moses Speak Attic? Jewish Historiography and Scripture in the Hellenistic Period. Edited by Lester L. Grabbe. Sheffield: Sheffield Academic Press, 2001.

Graham, M. Patrick. The Utilization of 1 and 2 Chronicles in the Reconstruction of Israelite History in the Nineteenth Century. SBLDS, 116. Atlanta: Scholars Press, 1990.

Graham, M. Patrick and Steven L. McKenzie, eds. The Chronicler as Author: Studies in Text and Texture. JSOTSup 263. Sheffield: Sheffield Academic Press, 1999.

Gunn, David M. The Fate of King Saul: An Interpretation of a Biblical Story. JSOTSup 14. Sheffield: Sheffield Academic Press, 1980.

Halpern, Baruch. David's Secret Demons: Messiah, Murderer, Traitor, King. Grand Rapids: Eerdmans, 2001.

Hawk, L. Daniel. Joshua. Berit Olam. Collegeville, MN: Liturgical Press, 2000.

Ho, Craig Y.S. "Conjectures and Refutations: Is 1 Samuel XXXI 1-13 Really the Source of 1 Chronicles X 1-12?" VT 45(1995): 82-106.

Ho, Craig Y.S. "The Stories of the Family Troubles of Judah and David: A Study of Their Literary Links." VT 49(1999): 514-531.

Hoglund, Kenneth G. "The Achaemenid Context." Pages 54-72 in Second Temple Studies: 1. Persian Period. Edited by Philip R. Davies. JSOTSup 177. Sheffield: Sheffield Academic Press, 1991.

Hoglund, Kenneth G. "The Chronicler as Historian: A Comparativist Perspective." Pages 19-29 in The Chronicler as Historian. Edited by M. Patrick Graham, Kenneth G. Hoglund and Steven L. McKenzie. Sheffield: Sheffield Academic Press, 1997. 
Humphreys, W.L. "A Life-Style for Diaspora: A Study of the Tales of Esther and Daniel." Journal of Biblical Literature 92(1991): 211-23.

Janzen, David. Witch-Hunts, Purity and Social Boundaries: The Expulsion of the Foreign Women in Ezra 9-10. JSOTSup 350. London: Sheffield Academic Press, 2002.

Japhet, Sara. I \& II Chronicles: A Commentary. Old Testament Library series. Louisville:

Westminster John Knox Press, 1993.

Japhet, Sara. "The Historical Reliability of Chronicles: The History of the Problem and its Place in Biblical Research.” JSOT 3 (1985): 83-107.

Japhet, Sara. The Ideology of the Book of Chronicles and its Place in Biblical Thought. Translated by Anna Barber. Winona Lake, IN: Eisenbrauns, 2009 (first English edition 1997; Hebrew original 1989).

Japhet, Sara. "The Supposed Common Authorship of Chronicles and Ezra-Nehemiah Investigated Anew." VT 18(1968): 330-371.

Jobling, David. 1 Samuel. Berit Olam. Collegeville, MN: Liturgical Press, 1998.

Jobling, David. "Text and the World-An Unbridgeable Gap? A Response to Carroll, Hoglund and Smith.” Pages 175-182 in Second Temple Studies: 1. Persian Period. Edited by Philip R. Davies. JSOTSup 177. Sheffield: Sheffield Academic Press, 1991.

Johnstone, William. 1 and 2 Chronicles. 2 vols. Sheffield: Sheffield Academic Press, 1997.

Jonker, Louis C. “The Chronicler and the Prophets: Who Were His Authoritative Sources?" Pages 145-164 in What Was Authoritative for Chronicles? Edited by Ehud Ben Zvi and Diana Edelman. Winona Lake, IN: Eisenbrauns, 2011.

Jonker, Louis C. "David's Officials According to the Chronicler (1 Chronicles 23-27): A Reflection of Second Temple Self-Categorization?" Pages 65-91 in Historiography and Identity (Re)formulation in Second Temple Historiographical Literature. Edited by Louis C. Jonker. New York: T\&T Clark, 2010.

Jonker, Louis C. "Engaging with Different Contexts: A Survey of the Various Levels of Identity Negotiation in Chronicles." Pages 63-93 in Texts, Contexts and Readings in Postexilic Literature. Edited by Louis C. Jonker. Tübingen: Mohr-Siebeck, 2011.

Jonker, Louis C. “Of Jebus, Jerusalem and Benjamin: The Chronicler's Sondergut in 1 Chronicles 21 Against the Background of the Late Persian Era in Yehud." Pages 81-102 in Chronicling the Chronicler: The Book of Chronicles and Early Second Temple Historiography. Edited by Tyler F. Williams and Paul S. Evans. Winona Lake, IN: Eisenbrauns, 2013.

Jonker, Louis C. "Reforming History: The Hermeneutical Significance of the Books of Chronicles." VT 57 (2007): 21-44. 
Jonker, Louis C. "Revisiting the Saul Narrative in Chronicles: Interacting with the Persian Imperial Context?" OTE 23 (2010): 283-305.

Jonker, Louis C. "Textual Identities in the Books of Chronicles: The Case of Jehoram's History." Pages 197-217 in Community Identity in Judean Historiography: Biblical and Comparative Perspectives. Edited by Gary N. Knoppers and Kenneth A. Ristau. Winona Lake, IN: Eisenbrauns, 2009.

Jonker, Louis C. "Was the Chronicler More Deuteronomic Than the Deuteronomist? Explorations Into the Chronicler's Relationship With Deuteronomic Legal Traditions.” SJOT 27 (2013): 191-203.

Jonker, Louis C. "Who Constitutes Society? Yehud's Self-understanding in the Late Persian Era as Reflected in the Books of Chronicles." JBL 127 (2008): 703-724.

Kalimi, Isaac. An Ancient Israelite Historian: Studies in the Chronicler, His Time, Place and Writing. SSN 46. Assen: Van Corcum, 2005.

Kalimi, Isaac. "Was the Chronicler a Historian?" Pages 73-89 in The Chronicler as Historian. Edited by M. Patrick Graham, Kenneth G. Hoglund and Steven L. McKenzie. Sheffield: Sheffield Academic Press, 1997.

Kertzer, Morris N. What Is a Jew? New York: Macmillan Publishing Co, 1975.

Klein, Lillian R. The Triumph of Irony in the Book of Judges. JSOTSup 68. Sheffield: Almond Press, 1988.

Klein, Ralph W. 1 Chronicles: A Commentary. Hermeneia series. Minneapolis: Fortress Press, 2006.

Klein, Ralph W. 2 Chronicles: A Commentary. Hermeneia series. Minneapolis: Fortress Press, 2012.

Klein, Ralph W. Israel in Exile: A Theological Interpretation. Philadelphia: Fortress Press, 1979. Knauf, Ernst A. "Bethel: The Israelite Impact on Judean Language and Literature.” Pages 291-349 in Judah and the Judeans in the Persian Period. Edited by Oded Lipschits and Manfred Oeming. Winona Lake, IN: Eisenbrauns, 2006.

Knoppers, Gary N. 1 Chronicles: A New Translation with Introduction and Commentary. 2 vols. Anchor Bible Commentary. New York: Doubleday, 2004.

Knoppers, Gary N. “Greek Historiography and the Chronicler's History: A Reexamination.” JBL 2003 (122): 627-650.

Knoppers, Gary N. "Hierodules, Priests, or Janitors? The Levites in Chronicles and the History of the Israelite Priesthood." JBL 118 (1999): 49-72. 
Knoppers, Gary N. "History and Historiography: The Royal Reforms." Pages 178-203 in The Chronicler as Historian. Edited by M. Patrick Graham, Kenneth G. Hoglund and Steven L. McKenzie. Sheffield: Sheffield Academic Press, 1997.

Knoppers, Gary N. "Is There a Future for the Deuteronomistic History?" Pages 119-34 in The Future of the Deuteronomistic History. Edited by Thomas C. Römer. BETL 147. Leuven: Leuven University Press, 2004.

Knoppers, Gary N. "Israel's First King and 'the Kingdom of YHWH in the hands of the sons of David': The Place of the Saulide Monarchy in the Chronicler's Historiography." Pages 187213 in Saul in Story and Tradition. Edited by Carl S. Ehrlich and Marsha C. White. FAT 47. Tübingen: Mohr-Siebeck, 2006.

Knoppers, Gary N. "The Relationship of the Deuteronomistic History to Chronicles: Was the Chronicler a Deuteronomist?" Pages 307-341in Congress Volume Helsinki 2010. Proceedings of the $20^{\text {th }}$ Congress of the International Organization for the Study of the Old Testament. Edited by Martti Nissinen. VTSup 148. Leiden: Brill, 2012.

Knoppers, Gary N. "Revisiting the Samarian Question in the Persian Period." Pages 265-289 in Judah and the Judeans in the Persian Period. Edited by Oded Lipschits and Manfred Oeming. Winona Lake, IN: Eisenbrauns, 2006.

Knoppers, Gary N. "Shem, Ham and Japheth: The Universal and the Particular in the Genealogy of Nations." Pages 13-31 in The Chronicler as Theologian: Essays in Honor of Ralph W. Klein. Edited by M. Patrick Graham, Steven L. McKenzie, and Gary N. Knoppers. JSOTSup 371. New York: T\&T Clark, 2003.

Knoppers, Gary N. Two Nations Under God: The Deuteronomistic History of Solomon and the Dual Monarchies. 2 vols. HSM 52, 53. Atlanta: Scholars Press, 1993, 1994.

Knowles, Melody D. Centrality Practiced: Jerusalem in the Religious Practice of Yehud \& the Diaspora in the Persian Period. Atlanta: SBL, 2006.

Koch, Klaus. "Ezra and the Origins of Judaism.” Journal of Semitic Studies 19 (1974): 173-97. Kreuzer, Siegfried. "Saul—Not Always—at War: A New Perspective on the Rise of Kingship in Israel." Pages 39-58 in Saul in Story and Tradition. Edited by Carl S. Ehrlich and Marsha C. White. FAT 47. Tübingen: Mohr-Siebeck, 2006.

Kuhrt, Amélie. The Persian Empire: A Corpus of Sources from the Achaemenid Period. London: Routledge, 2010 (2007).

Langston, Scott M. Cultic Sites in the Tribe of Benjamin: Benjaminite Prominence in the Religion of Israel. New York: Peter Lang Publishing, 1998.

Lazear, Edward P. “Economic Imperialism.” Quarterly Journal of Economics 115(2000): 99-146. 
Lemche, Niels Peter. The Israelites in History and Tradition. Louisville: Westminster John Knox Press, 1998.

Lemke, Werner E. “The Synoptic Problem in the Chronicler's History.” HTR 58(1965): 349-363.

Leuchter, Mark. “'The Levite in Your Gates': The Deuteronomic Redefinition of Levitical Authority." JBL 126 (2007): 417-436.

Levin, Yigal. "Joseph, Judah and the 'Benjamin Conundrum.'” ZAW 116 (2004): 223-241.

Levin, Yigal. "Who Was the Chronicler's Audience? A Hint from His Genealogies." JBL 122(2003): 229-245.

Levtow, Nathaniel B. "Text Production and Destruction in Ancient Israel: Ritual and Political Dimensions." Pages 111-139 in Social Theory and the Study of Israelite Religion: Essays in Retrospect and Prospect. Edited by Saul M. Olyan. Atlanta: Society of Biblical Literature, 2012.

Lipschits, Oded. "Achaemenid Imperial Policy, Settlement Processes in Palestine, and the Status of Jerusalem in the Middle of the Fifth Century B.C.E." Pages 19-52 in Judah and the Judeans in the Persian Period. Edited by Oded Lipschits and Manfred Oeming. Winona Lake, IN: Eisenbrauns, 2006.

Lipschits, Oded. The Fall and Rise of Jerusalem: Judah Under Babylonian Rule. Winona Lake, IN: Eisenbrauns, 2005.

Lipschits, Oded. "The History of the Benjamin Region under Babylonian Rule." Tel Aviv 26(1999): 155-90.

Lipschits, Oded, Gary N. Knoppers, and Manfred Oeming, eds. Judah and the Judeans in the Achaemenid Period: Negotiating Identity in an International Context. Winona Lake, IN: Eisenbrauns, 2011.

Long, V. Philips. The Reign and Rejection of King Saul: A Case for Literary and Theological Coherence. Atlanta: Scholars Press, 1989.

Longacre, Robert E. "Discourse Perspective on the Hebrew Verb: Affirmation and Restatement." Pages 177-89 in Linguistics and Biblical Hebrew. Edited by Walter Bodine. Winona Lake, IN: Eisenbrauns, 1992.

Löwisch, Ingeborg. "Cracks in the Male Mirror: References to Women as Challenges to Patilinear Authority in the Genealogies of Judah." Pages 105-132 in What Was Authoritative for Chronicles? Edited by Ehud Ben Zvi and Diana Edelman. Winona Lake, IN: Eisenbrauns, 2011.

Magen, Yitzhak et al., eds. The Land of Benjamin. Jerusalem: Israel Antiquities Authority, 2004. Master, Daniel M. "State Formation Theory and the Kingdom of Ancient Israel." JNES 60(2001): 117-131. 
McCarter, P. Kyle, Jr. I Samuel. Anchor Bible Commentary. Garden City, NY: Doubleday, 1980.

McCarter, P. Kyle, Jr. II Samuel. Anchor Bible Commentary. Garden City, NY: Doubleday, 1984.

McConville, J. Gordon. "Ezra-Nehemiah and the Fulfillment of Prophecy." VT 36 (1986): 205-24.

McConville, J. Gordon. I \& II Chronicles. Philadelphia: Westminster Press, 1984.

McKenzie, Steven L. "The Chronicler as Redactor.” Pages 70-90 in The Chronicler as Author:

Studies in Text and Texture. Edited by M. Patrick Graham and Steven L. McKenzie.

JSOTSup 263. Sheffield: Sheffield Academic Press, 1999.

McKenzie, Steven L. The Chronicler's Use of the Deuteronomistic History. HSM 33. Atlanta:

Scholars Press, 1985.

McKenzie, Steven L. 1-2 Chronicles. Nashville: Abingdon Press, 2004.

McKenzie, Steven L. "1 and 2 Samuel.” In The New Oxford Annotated Bible: New Revised

Standard Edition with Apocrypha, Augmented Third Edition. Edited by Michael D. Coogan.

New York: Oxford University Press, 2007.

McKenzie, Steven L. King David: A Biography. New York: Oxford University Press, 2000.

McKenzie, Steven L. "Saul in the Deuteronomistic History." Pages 59-70 in Saul in Story and

Tradition. Edited by Carl S. Ehrlich and Marsha C. White. FAT 47. Tübingen: MohrSiebeck, 2006.

McLean, Iain. "William H. Riker and the Invention of Heresthetic(s)." British Journal of Political Science 32 (2002): 535-558.

Middlemas, Jill. The Templeless Age. Louisville: Westminster John Knox Press, 2007.

Miller, Geoffrey P. "Verbal Feud in the Hebrew Bible: Judges 3:12-30 and 19-21." JNES 55 (1996): 105-117.

Mitchell, Christine. “"How Lonely Sits the City': Identity and the Creation of History.” Pages 71-83 in Approaching Yehud: New Approaches to the Study of the Persian Period. Edited by Jon L. Berquist. Atlanta: Society of Biblical Literature, 2007.

Mobley, Gregory. "Glimpses of the Heroic Saul.” Pages 80-87 in Saul in Story and Tradition.

Edited by Carl S. Ehrlich and Marsha C. White. FAT 47. Tübingen: Mohr-Siebeck, 2006.

Mobley, Gregory. "Hosea." In The New Oxford Annotated Bible: New Revised Standard Edition with Apocrypha, Augmented Third Edition. Edited by Michael D. Coogan. New York: Oxford University Press, 2007.

Myers, J.M. 1 Chronicles. 1965.

Na'aman, Nadav. "Canaanite Jerusalem and its Central Hill Country Neighbours in the Second Millennium B.C.E.” UF 24 (1992): 275-291.

Na'aman, Nadav. “The Sanctuary of the Gibeonites Revisited.” JANER 9 (2009): 101-124. 
Na'aman, Nadav. "Saul, Benjamin and the Emergence of 'Biblical Israel' (Parts 1 \& 2)." ZAW 121 (2009): 211-224, 335-349.

Nelson, Richard D. Joshua: A Commentary. Old Testament Library series. Louisville: Westminster John Knox Press, 1997.

Newsome Jr., J.D. “Toward a New Understanding of the Chronicler and His Purpose.” JBL 94(1975): 201-203.

Niditch, Susan. Oral World and Written Word: Ancient Israelite Literature. Louisville:

Westminster John Knox Press, 1996.

Nihan, Christophe. "Saul among the Prophets (1 Sam 10:10-12 and 19:18-24): The Reworking of Saul's Figure in the Context of the Debate on 'Charismatic Prophecy' in the Persian Era." Pages 88-118 in Saul in Story and Tradition. Edited by Carl S. Ehrlich and Marsha C. White. FAT 47. Tübingen: Mohr-Siebeck, 2006.

North, R. "Theology of the Chronicler." JBL 82(1963): 369-381.

O'Brien, Mark A. "The Contribution of Judah's Speech, Genesis 44:18-34, to the Characterization of Joseph." CBQ 59 (1997): 429-47.

O’Brien, Mark A. The Deuteronomistic History Hypothesis: A Reassessment.Göttingen:

Vandenhoeck \& Ruprecht, 1989.

O'Connell, Robert H. The Rhetoric of the Book of Judges. VTSup 63. Leiden: Brill, 1996.

Oeming, Manfred. Das wahre Israel: Die "geneologische Vorhalle" 1 Chronik 1-9. BWANT 128. Stuttgart: Kohlhammer, 1990.

Peltonen, Kai. "Function, Explanation and Literary Phenomena: Aspects of Source Criticism as Theory and Method in the History of Chronicles Research." Pages 18-69 in The Chronicler as Author: Studies in Text and Texture. Edited by M. Patrick Graham and Steven L.

McKenzie. JSOTSup 263. Sheffield: Sheffield Academic Press, 1999.

Peltonen, Kai. “A Jigsaw Without A Model? The Date of Chronicles.” Pages 225-271 in Did Moses Speak Attic? Jewish Historiography and Scripture in the Hellenistic Period. Edited by Lester L. Grabbe. JSOTSup 317. Sheffield: Sheffield Academic Press, 2001.

Person, Raymond F. "The Deuteronomic History and the Books of Chronicles: Contemporary Competing Historiographies." Pages 315-336 in Reflection and Refraction: Studies in Biblical Historiography in Honour of A. Graeme Auld. Edited by R. Rezetko et al. Leiden: Brill, 2007.

Person, Raymond F. The Deuteronomic History and the Book of Chronicles: Scribal Works in an Oral World. Atlanta: Society of Biblical Literature, 2010.

Person, Raymond F. The Deuteronomic School: History, Social Setting, and Literature. Atlanta: Society of Biblical Literature, 2002. 
Polzin, Robert. David and the Deuteronomist: 2 Samuel. Bloomington, IN: Indiana University Press, 1993.

Polzin, Robert. Late Biblical Hebrew: Toward an Historical Typology of Biblical Hebrew Prose. HSM 12. Missoula, MT: Scholars Press, 1976.

Provan, Iain W. "1 and 2 Kings.” In The New Oxford Annotated Bible: New Revised Standard Edition with Apocrypha, Augmented Third Edition. Edited by Michael D. Coogan. New York: Oxford University Press, 2007.

Radnitzky, Gerard and Peter Bernholz, eds. Economic Imperialism: The Economic Approach Applied Outside the Field of Economics. New York: Paragon House, 1987.

Rainey, Anson F. “The Chronicler and His Sources-Historical and Geographical.” Pages 30-72 in The Chronicler as Historian. Edited by M. Patrick Graham, Kenneth G. Hoglund and Steven L. McKenzie. Sheffield: Sheffield Academic Press, 1997.

Rendsburg, Gary A. "The Internal Consistency and Historical Reliability of the Biblical Genealogies." VT 40 (1990): 185-206.

Rezetko, Robert, et al., eds. Reflection and Refraction: Studies in Biblical Historiography in Honour of A. Graeme Auld. Leiden: Brill, 2007.

Ricoeur, Paul. Memory, History, Forgetting. Translated by K. Blamey and D. Pellauer. Chicago: University of Chicago Press, 2004.

Ricoeur, Paul. "The 'Sacred' Text and the Community." Translated by David Pellauer. Pages 68-72 in Figuring the Sacred: Religion, Narrative and Imagination. Edited by M.I. Wallace. Minneapolis: Fortress Press, 1995.

Riker, William H. The Art of Political Manipulation. New Haven: Yale University Press, 1986.

Ristau, Kenneth A. "Breaking Down Unity: An Analysis of 1 Chronicles 21.1-22.1.” JSOT 30.2 (2005): 201-221.

Römer, Thomas C. "Entstehungsphasen des 'deuteronomistischen Geschichtswerkes.” Pages 45-70 in Die deuteronomistischen Geschichtswerke: Redaktions- und religionsgeschichtliche Perspektiven zur "Deuteronomismus"-Diskussion in Torah und Vorderen Propheten. Edited by Markus Witte et al. BZAW 365. Berlin: de Gruyter, 2006.

Römer, Thomas C. The So-Called Deuteronomistic History: A Sociological, Historical and Literary Introduction. London: T\&T Clark, 2005.

Rösel, Hartmut N. Joshua. Historical Commentary on the Old Testament. Leuven: Peeters, 2011.

Rudolph, W. Chronikbücher. 1955. Chs. 3, 6-7

Schiffman, Lawrence. From Text to Tradition. Hoboken, N.J.: Ktav Publishing House, 1991.

Schneider, Tammi J. Judges. Berit Olam. Collegeville, MN: Liturgical Press, 2000. 
Schniedewind, William M. "Prophets and Prophecy in the Books of Chronicles." Pages 204-224 in The Chronicler as Historian. Edited by M. Patrick Graham, Kenneth G. Hoglund and Steven L. McKenzie. Sheffield: Sheffield Academic Press, 1997.

Schnittjer, Gary E. The Torah Story: An Apprenticeship on the Pentateuch. Grand Rapids: Zondervan, 2006.

Schofield, Norman. "Constitutions, Voting and Democracy: A Review." Social Choice and Welfare 18 (2001): 571-600.

Schunck, Klaus-Dietrich. “Benjamin.” Translated by Phillip R. Callaway. Pages 671-673 in Anchor Bible Dictionary, vol. 1. Edited by David Noel Freedman. New York: Doubleday Publishing, 1992.

Schunck, Klaus-Dietrich. Benjamin: Untersuchungen zur Entstehung und Geschichte eines israelitischen Stammes. BZAW 86. Berlin: Alfred Töpelmann, 1963.

Schweitzer, Steven J. Reading Utopia in Chronicles. LHBOTS 442. London: T\&T Clark, 2007.

Seitz, Christopher. Theology in Conflict: Reactions to the Exile in the Book of Jeremiah. Berlin: de Gruyter, 1989.

Shepsle, Kenneth A. "Losers in Politics (And How They Sometimes Become Winners): William Riker's Heresthetic.” Perspectives on Politics 1 (2003): 307-315.

Siedlecki, Armin. “'Persian Period Studies Have Come of Age."” Pages 123-131 in Historiography and Identity (Re)formulation in Second Temple Historiographical Literature. Edited by Louis C. Jonker. New York: T\&T Clark, 2010.

Ska, Jean-Louis. Introduction to Reading the Pentateuch. Translated by Sr. Pascale Dominique. Winona Lake, IN: Eisenbrauns, 2006.

Skinner, Kiron et al. The Strategy of Campaigning: Lessons from Ronald Reagan and Boris Yeltsin. Ann Arbor: University of Michigan Press, 2007.

Smith, Anthony D. The Ethnic Origins of Nations. Oxford: Blackwell, 1986.

Smith, Anthony D. The Ethnic Revival. Cambridge: Cambridge University Press, 1981.

Smith, M. Palestinian Parties and Politics that Shaped the Old Testament. New York, 1971.

Smith-Christopher, Daniel L. "Between Ezra and Isaiah: Exclusion, Transformation and Inclusion of the 'Foreigner' in Post-exilic Biblical Theology." Pages 117-142 in Ethnicity and the Bible. Edited by Mark G. Brett. Biblical Interpretation Series 19. Leiden: Brill, 1996.

Sparks, James T. The Chronicler's Genealogies: Towards an Understanding of 1 Chronicles 1-9. Atlanta: Society of Biblical Literature, 2008.

Stager, Lawrence E. "Forging an Identity: The Emergence of Ancient Israel." Pages 123-175 in The Oxford History of the Biblical World. Edited by Michael D. Coogan. New York: Oxford University Press, 1998. 
Steins, Georg. Die Chronik als kanonisches Abschlußphänomen: Studien zur Enstehung und Theologie von 1/2 Chronik. BBB 93. Weinheim: Beltz Athenäum, 1995.

Stern, Ephraim. Material Culture of the Land of the Bible in the Persian Period 538-332 B.C. Jerusalem: Israel Exploration Society. Warminster: Aris \& Phillips, 1982.

Stern, Ephraim. "New Evidence on the Administrative Division of Palestine in the Persian Period." Pages 221-226 in Achaemenid History IV: Centre and Periphery. Edited by Heleen SancisiWeerdenburg and Amélie Kuhrt. Leiden: Nederlands Instituut Voor Het Nabije Oosten, 1990.

Stern, Ephraim, and Yitzhak Magen. "Archaeological Evidence for the First Stage of the Samaritan Temple on Mt. Gerizim.” IEJ 52 (2002): 49-57.

Stigler, George J. "Economics-The Imperial Science?" Scandinavian Journal of Economics 86(1984): 301-313.

Talshir, David. “A Reinvestigation of the Linguistic Relationship Between Chronicles and EzraNehemiah." VT 38(1988): 165-193.

Thompson, Thomas L. The Mythic Past: Biblical Archaeology and the Myth of Israel. New York: Basic Books, 1999.

Throntveit, Mark A. “The Chronicler's Speeches and Historical Representation.” Pages 204-224 in The Chronicler as Historian. Edited by M. Patrick Graham, Kenneth G. Hoglund and Steven L. McKenzie. Sheffield: Sheffield Academic Press, 1997.

Throntveit, Mark A. "Linguistic Analysis and the Question of Authorship in Chronicles, Ezra, and Nehemiah.” VT 32(1982): 201-216.

Tuell, Steven S. First and Second Chronicles. Interpretation Series. Louisville: John Knox, 2001. van der Toorn, Karel. Scribal Culture and the Making of the Hebrew Bible. Cambridge: Harvard University Press, 2009.

von Rad, Gerhard. Theology of the Old Testament. English, vol 1, 347-354.

Webb, Barry G. The Book of Judges. NICOT. Grand Rapids: Eerdmans, 2012.

Webb, Barry G. The Book of Judges: An Integrated Reading. JSOTSup 46. Sheffield: JSOT Press, 1987.

Weinberg, Joel P. The Citizen-Temple Community. Translated by Daniel L. Smith-Christopher. JSOTSup 151. Sheffield: JSOT Press, 1992.

Weinberg, Joel P. “Das Wesen und funktionelle Bestimmung der Listen in 1 Chr 1-9.” ZAW 93 (1981): 91-114.

White, Marsha C. "Saul and Jonathan in 1 Samuel 1 and 14." Pages 119-138 in Saul in Story and Tradition. Edited by Carl S. Ehrlich and Marsha C. White. FAT 47. Tübingen: MohrSiebeck, 2006. 
Whitelam, Keith W. The Invention of Ancient Israel: The Silencing of Palestinian History. New York: Routledge, 1996.

Wiesehöfer, Josef. "The Achaemenid Empire." Pages 66-98 in The Dynamics of Ancient Empires. Edited by Ian Morris and Walter Scheidel. Oxford: Oxford University Press, 2009.

Wiesehöfer, Josef. "The Achaemenid Empire in the Fourth Century B.C.E.: A Period of Decline?" Pages 11-30 in Judah and the Judeans in the Fourth Century B.C.E. Edited by Oded Lipschits, Gary N. Knoppers and Rainer Albertz. Winona Lake, IN: Eisenbrauns, 2007. Wiesehöfer, Josef. Ancient Persia From 550 BC to 650 AD. Translated by Azizeh Azodi. New York: I.B. Tauris, 2001 (1996).

Wiesehöfer, Josef. "From Achaemenid Imperial Order to Sasanian Diplomacy: War, Peace, and Reconciliation in Pre-Islamic Iran.” Pages 121-140 in War and Peace in the Ancient World. Edited by Kurt A. Raaflaub. London: Blackwell, 2007.

Willi, Thomas. Die Chronik als Auslegung: Undersuchungen zur literarischen Gestaltung der historischen Überlieferung Israels. FRLANT 106. Göttingen: Vandenhoeck \& Ruprecht, 1972.

Willi, Thomas. "Late Persian Judaism and its Conception of an Integral Israel According to Chronicles: Some Observations on Form and Function of the Genealogy of Judah in 1 Chronicles 2.3-4.23." Pages 146-162 in Second Temple Studies 2. Temple Community in the Persian Period. Edited by Tamara C. Eskenazi and Kent H. Richards. Sheffield: Sheffield Academic, 1994.

Williamson, H.G.M. 1 and 2 Chronicles. Grand Rapids: Eerdmans, 1982.

Williamson, H.G.M. Israel in the Books of Chronicles. Cambridge: Cambridge University Press, 1977.

Wright, John W. "The Fight for Peace: Narrative and History in the Battle Accounts in Chronicles." Pages 150-177 in The Chronicler as Historian. Edited by M. Patrick Graham, Kenneth G. Hoglund and Steven L. McKenzie. Sheffield: Sheffield Academic Press, 1997.

Wright, John W. "The Priestly Center of the Sons of Levi: Temple Familial Patronage

Differentiation in the Book of Chronicles." Paper for the annual meeting of the Society of Biblical Literature (Chicago: November, 2012).

Wright, John W. "Remapping Yehud: The Borders of Yehud and the Genealogies of Chronicles." Pages 67-89 in Judah and the Judeans in the Persian Period. Edited by Oded Lipschits and Manfred Oeming. Winona Lake, IN: Eisenbrauns, 2006.

Wright, John W. “'Those Doing the Work for the Service in the House of the Lord': 1 Chronicles 23:6-24:31 and the Socio-Historical Context for the Temple of Yahweh in Jerusalem in the Late Persian/Early Hellenistic Period." Pages 361-384 in Judah and the Judeans in the 
Fourth Century B.C.E. Edited by Oded Lipschits, Gary N. Knoppers and Rainer Albertz. Winona Lake, IN: Eisenbrauns, 2007.

Younger, K. Lawson. "Judges." In The New Oxford Annotated Bible: New Revised Standard Edition with Apocrypha, Augmented Third Edition. Edited by Michael D. Coogan. New York: Oxford University Press, 2007. 